\title{
DESEMPENHO ESTRUTURAL DE PAREDES DE ALVENARIA DE BLOCOS DE CONCRETO DE AGREGADOS RECICLADOS DE REJEITOS DE CONSTRUÇÃO E DEMOLIÇÃO
}

Fábio Braga da Fonseca

Dissertação apresentada à Escola de Engenharia de São Carlos da Universidade de São Paulo, como parte dos requisitos para obtenção do título de Mestre em Engenharia de Estruturas

ORIENTADOR: Prof. Dr. Eloy Ferraz Machado Jr.

São Carlos 
2002

Aos meus pais, amigos $e$ a Deus, que me incentivaram e me orientaram a vencer mais uma grande etapa. 
Aos meus familiares, que me auxiliaram em todos os momentos $\mathrm{e}$ circunstancias.

À minha grande amiga e namorada Fabiana Biagione, pelo incentivo e apoio. Aos meus amigos Fernando Grande, Clayton, Fernando Mendes, Alexandre, Rodrigo, Ricardo, Gustavo, Andrei, Valentim, Joel, Adilson e Fabiana Oliveira.

Agradeço o auxílio técnico dos seguintes funcionários do Laboratório de Estruturas: Luiz Vareda, Amauri, Mário, Valdir, Mauri, Fabiano, Juliano e Waldemir.

Agradeço principalmente ao professor Dr. Eloy, pela excelente consideração, orientação e conhecimentos fornecidos durante a elaboração desta pesquisa.

Aos professores Humberto, Márcio Corrêa, Márcio Ramalho e Samuel, pelo esclarecimento técnico.

Aos funcionários Sérgio e Paulo do Laboratório de Materiais de Construção Civil, e ao professor Osni, pelo excelente ensinamento técnico.

Aos funcionários do Laboratório de Geologia de Engenharia, pela disposição de equipamento.

Aos colegas e ao professor Jefferson, pelo esclarecimento técnico e empréstimo de equipamentos do Laboratório de Materiais Avançados à Base de Cimento.

À coordenadoria de Aperfeiçoamento de Pessoal de Nível Superior CAPES, pela bolsa de estudo concedida.

Aos funcionários da secretaria e biblioteca do Depto. de Engenharia de Estruturas. 


\section{SUMÁRIO}

LISTA DE FIGURAS i i

LISTA DE TABELAS IV iv

RESUMO vi vi

ABSTRACT Vii

1. INTRODUÇÃO —_ 1

1.1 Objetivos ....................................................................... 4

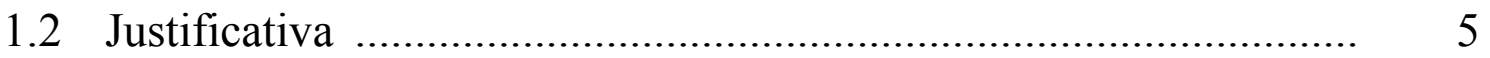

1.2.1 Agregados reciclados ...................................................... 5

1.2.2 Racionalização na construção …............................................ 9

1.3 Apresentação do trabalho ................................................... 11

2. REVISÃO BIBLIOGRÁFICA — 12

2.1 Agregados reciclados ............................................................ 13

2.1.1 Aplicação ....................................................................... 14

2.1.2 Características físicas dos agregados reciclados $\quad$.................... 16

2.1.2.1 Argamassa aderida no agregado reciclado ........................... 18

2.1.2.2 Influência do consumo de cimento ....................................... 20

2.1.3 Absorção de água dos agregados reciclados ........................... 21

2.1.4 Produtos de concreto com agregado reciclado ....................... 25

2.1.4.1 Blocos de concreto 25

2.1.4.2 Argamassas e concretos de agregado reciclado 26

2.2 Alvenaria ........................................................................ 28

2.2.1 Princípios da alvenaria ........................................................ 28

2.2.2 Desempenho mecânico da alvenaria ...................................... 29

2.2.2.1 Componentes de alvenaria 29

2.2.2.2 Paredes de alvenaria $\quad 32$

2.2.3 Mecanismo de ruptura $\quad$........................................................ 39

2.2.3.1 Qualidade 40

2.2.4 Estudo de paredes de alvenaria ........................................... 41

2.2.4.1 Eficiência de blocos, prisma se paredes 41

2.2.4.2 Paredes e prismas revestidos com argamassa simples 41

2.2.4.3 Influência do assentamento de prismas com argamassas distintas 42

2.2.4.4 Revestimento de paredes de alvenaria com argamassas distintas 43 
2.2.4.5 Juntas verticais de paredes de alvenaria não preenchidas

2.3 Concreto com abatimento nulo ................................................ 45

2.3.1 Aplicação ........................................................................ 46

2.3.2 Conceitos de concreto compactado a rolo ............................. 47

2.3.3 Materiais ......................................................................... 48

2.3.4 Métodos para medir a consistência ....................................... 49

2.3.5 Energia de vibração e resistência à compressão do elemento $\quad$.. $\quad 51$

2.3.6 Controle do concreto e da concretagem ............................... 52

2.3.7 Metodologia de dosagem para concretos de abatimento nulo .. 55

2.3.7.1 Associação Brasileira de Cimento Portland 55

2.3.7.2 American Concrete Institute (ACI 211.3-75) 56

3. METODOLOGIA EMPREGADA 59

3.1 Estudos preliminares ........................................................... 59

3.2 Execução de ensaios em blocos, prismas e painéis de alvenaria ... 60

3.3 Execução de ensaios em argamassas ......................................... 63

3.3.1 Resistência de aderência à tração

3.3.2 Módulo de deformação das argamassas ................................. 66

3.3.3 Profundidade de carbonatação das argamassas $\quad$...................... 67

4. ESTUDO EXPERIMENTAL

4.1 Processo de fabricação de blocos de concreto ............................ 71

4.2 Estudo de traço de blocos de concreto e argamassa .................... 74

4.2.1 Bloco de concreto piloto .................................................. 75

4.2.1.1 Características dos materiais utilizados para o estudo de bloco de concreto $\quad 75$

4.2.1.2 Proporcionamento entre agregados $\quad 76$

4.2.1.3 Dosagem do concreto $\quad 77$

4.2.1.4 Resistência à compressão dos corpos-de-prova cilíndricos 78

4.2.1.5 Fabricação de blocos piloto de concreto 80

4.2.1.6 Absorção e área líquida $\quad 82$

4.2.2 Argamassa .................................................................. 82

4.2.2.1 Características dos materiais utilizados para o estudo de argamassa $\quad 83$

4.2.2.2 Proporcionamento dos materiais e características das argamassas 85

4.2.2.3 Resistência à compressão e à tração por compressão diametral 86 
4.3 Obtenção de agregados reciclados

4.3.1 Análise dos agregados reciclados de RCD .............................. 90

5. FABRICAÇÃ̃O DE BLOCOS E

PAREDES DE ALVENARIA

5.1 Produção dos blocos de alvenaria (.................................................. 94

5.2 Confecção de paredes e prismas de alvenaria ............................... 96

5.2.1 Prismas e painéis de alvenaria destinados à determinação da resistência à compressão axial .............................................. 96

5.2.2 Painel para o ensaio de aderência à tração do revestimento $\quad$..... 98

6. ANÁLISE DOS RESULTADOS

6.1 Ensaios em blocos, prismas e paredes ....................................... 102

6.1.1 Caracterização dos lotes de blocos de concreto ......................... 102

$\begin{array}{lll}6.1 .1 .1 & \text { Resistência à compressão } & 102\end{array}$

6.1.1.2 Absorção de água, área líquida, massa específica e teor de umidade 104

6.1.2 Resistência à compressão dos prismas e paredes ……............. 105

6.1.3 Módulo de deformação ........................................................... 109

$\begin{array}{ll}\text { 6.1.3.1 Blocos de concreto } & 109\end{array}$

$\begin{array}{ll}\text { 6.1.3.2 Paredes de alvenaria } & 111\end{array}$

6.2 Ensaios em argamassas ............................................................. 115

6.2.1 Determinação do módulo de deformação da argamassa $\quad$.......... 115

6.2.2 Resistência de aderência à tração
do revestimento de argamassa $\ldots \ldots \ldots \ldots \ldots \ldots \ldots \ldots \ldots \ldots \ldots \ldots \ldots \ldots \ldots \ldots \ldots \ldots \ldots \ldots \ldots$

6.2.3 Análise da carbonatação .......................................................... 124

$\begin{array}{lr}\text { 7. CONCLUSÕES } & 127\end{array}$

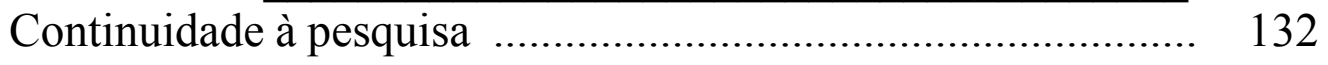

BIBLIOGRAFIA

ANEXO A - Principais características dos lotes de blocos

ANEXO B - Desempenho mecânico dos prismas, paredes e argamassas

ANEXO C - Argamassas de assentamento e de revestimento 


\section{LISTA DE FIGURAS}

Figura 1.1 - Unidades residenciais licenciadas no mesmo período ……............... 10

Figura 1.2 - Casa 1.0 construída com blocos de concreto …............................... 10

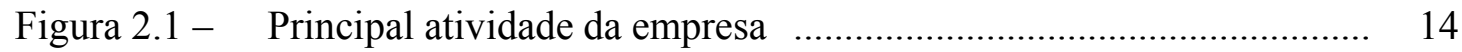

Figura 2.2 - Perda de material f............................................................................ 14

Figura 2.3 - Comparação visual de arredondamento e esfericidade do grão de areia

Figura 2.4 - Correlação entre a quantidade de argamassa aderida aos grãos e a absorção de água dos agregados reciclados de concreto $\quad$............. 19

Figura 2.5 - Influência da secagem na permeabilidade dos concretos ................. 20

Figura 2.6 - Resistência à compressão x consumo de cimento _........................... 20

Figura 2.7 - Curvas de perda do abatimento de concretos com

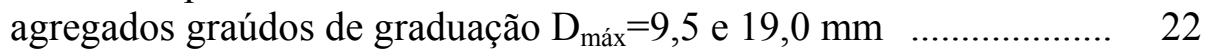

Figura 2.8 - Processo de absorção de água do agregado ...................................... 23

Figura 2.9 - Curva do percentual de absorção do agregado reciclado miúdo e graúdo, nas primeiras 24horas .......................... 24

Figura 2.10 - Zonas de transição do concreto ...................................................... 25

Figura 2.11 - Ensaio de resistência à tração indireta do bloco de alvenaria ........... 30

Figura 2.12 - Resistência de tração pelo método indireto e "blockbuster" ............ 31

Figura 2.13 - Método direto de tração "blockbuster" ........................................... 31

Figura 2.14 - Relação entre a resistência de cálculo da alvenaria e a resistência à compressão dos materiais constituintes $\quad$..................... 32

Figura 2.15 - Representação esquemática do comportamento tensão-deformação do concreto sob compressão simples $\quad$................. 35

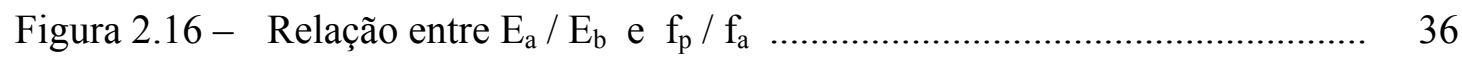

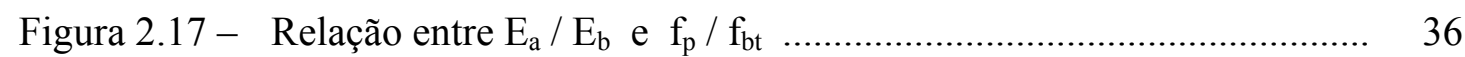

Figura 2.18 - Tipo de ruptura do bloco ocorrido nos prismas em função da argamassa ........................................................ 40

Figura 2.19 - Resistência à compressão e módulo de deformação dos prismas para argamassas com diferentes consumos de cimento $\quad$...... $\quad 43$

Figura 2.20 - Curva tensão-deformação da parede sem revestimento e das argamassas simples do revestimento

Figura 2.21 - Permeabilidade em paredes com revestimento em uma face variando o preenchimento da junta vertical de argamassa $\quad$............... $\quad 45$

Figura 2.22 - Resistência simples à compressão do concreto compactado a rolo de elevado desempenho 
Figura 2.23- Curvas granulométricas para produção de

blocos de concreto e adoquines

Figura 2.24 - Aparelho de VeBe ................................................................. $\quad 50$

Figura 2.25 - Dependência entre a resistência e a relação a/c ............................... 51

Figura 2.26 - Efeito da quantidade de água nos concretos .................................... 52

Figura 2.27 - Ábaco de tendência à fissuração do concreto ................................... 55

Figura 3.1 - Posicionamento dos transdutores nos prismas, paredes sem e com revestimento

Figura 3.2 - Posicionamento da viga de distribuição na parede de alvenaria instrumentada ao pórtico de reação .............................. 62

Figura 3.3 - Ensaio de aderência de revestimentos _............................................ 64

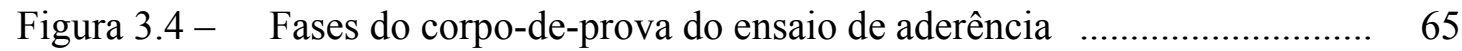

Figura 3.5 - Formas de ruptura no ensaio de aderência à tração do revestimento $\quad 65$

Figura 3.6 - Direção do efeito de carbonatação da argamassa de assentamento .. 68

Figura 4.1 - Vista geral da prensa hidro-pneumática utilizada para confecção dos blocos de concreto com função estrutural ......... 71

Figura 4.2 - Vista dos silos e balanças instalados no funil .................................. 71

Figura 4.3 - Misturador forçado de eixo horizontal f........................................... 72

Figura 4.4 - Processo de moldagem dos blocos $\quad$................................................. 73

Figura 4.5 - Estocagem dos blocos ................................................................. $\quad 74$

Figura 4.6 - Curvas granulométricas dos agregados utilizados para estudo do bloco de concreto .................................................. 75

Figura 4.7 - Máxima massa unitária compactada dos agregados reciclados em relação à quantidade de areia $\quad$................... 76

Figura 4.8 - Fluxograma da escolha do traço para a confecção dos blocos de concreto destinados aos painéis de alvenaria ............ 78

Figura 4.9 - Curva granulométrica dos agregados miúdos ................................. 83

Figura 4.10 - Curva de inchamento dos agregados miúdos f................................ 84

Figura 4.11 - Contacto entre corpos sólidos ……............................................... 85

Figura 4.12 - Desempenho das argamassas ao ensaio de compressão ................... 87

Figura 4.13 - Desempenho da argamassa ao ensaio de tração por compressão diametral ............................................................. 87

Figura 4.14 - Aspecto do lote recebido em setembro de 2001 ............................... 88

Figura 4.15 - Curvas granulométricas das amostras de agregados reciclados de RCD ................................................ 89

Figura 4.16 - Processo de peneiramento dos agregados reciclados $\quad$....................... 89 
Figura 4.17 - Processo de re-britagem de entulho

Figura 4.18 - Comparação das curvas granulométricas dos agregados

reciclados utilizados à fabricação dos blocos de concreto

Figura 4.19 - Curva granulométrica composta dos agregados destinados à fabricação de blocos de concreto

Figura 4.20 - Natureza da composição do agregado reciclado

Figura 5.1 - Permanência dos blocos às chapas metálicas por 5 dias 95

Figura 5.2 - Absorção de água da argamassa de assentamento pelo bloco de concreto

Figura 5.3 - Absorção de água da argamassa de revestimento pelo bloco de concreto e chapisco

Figura 5.4 - Retração no revestimento de argamassa reciclada $\quad$........................... 97

Figura 5.5 - Vista das paredes e prismas de alvenaria ......................................... 98

Figura 5.6 - Dispositivo de corte do revestimento f............................................. 99

Figura 5.7 - Vista do dispositivo de aderência à tração da argamassa de revestimento

Figura $6.1-\quad$ Desenvolvimento da resistência característica

dos blocos produzidos

Figura 6.2 - Ruptura típica dos blocos vazados de concreto de alvenaria com função estrutural

Figura 6.3 - Distribuição do carregamento à alvenaria ....................................... 106

Figura 6.4 - Variação do módulo de deformação ................................................. 111

Figura 6.5 - Diagramas tensão-deformação das paredes com e sem revestimento 113

Figura 6.6 - Fissuração típica das paredes revestidas f......................................... 114

Figura 6.7 - Diagramas tensão-deformação das argamassas $\quad$................................ 115

Figura 6.8 - Curva tensão-deformação das argamassas e das paredes sem revestimentos ….............................................. 117

Figura 6.9 - Execução do ensaio de aderência da argamassa _............................... 118

Figura 6.10 - Comparativo das resistências de aderência à tração ……................. 119

Figura 6.11 - Aderência entre chapisco e argamassa de revestimento, em parede de bloco de concreto com argamassa de assentamento contendo agregado natural

Figura 6.12 - Aderência entre chapisco e argamassa de revestimento, em parede de bloco de concreto com argamassa de assentamento contendo agregado reciclado

Figura 6.13 - Profundidade média de carbonatação das argamassas .................... 124

Figura 6.14 - Presença de carbonato de cálcio lixiviado das argamassas de revestimento

Figura 6.15 - Profundidade de carbonatação no bloco de concreto 


\section{LISTA DE TABELAS}

Tabela 1.1 - Quantidade de entulho em relação ao total de resíduos em aterros públicos

Tabela 2.1 - Características físicas dos agregados _.............................................. 16

Tabela 2.2 - Esfericidade e arredondamento característicos dos agregados ........ 16

Tabela 2.3 - Influência da argamassa aderida .................................................. 18

Tabela 2.4 - Resultados dos ensaios de verificação de resistência _....................... 21

Tabela 2.5 - Classificação da água presente na pasta de cimento ……………...... 22

Tabela 2.6 - Estudo de dosagem para determinação do traço e

Tabela 2.7 - Composição e resultados dos ensaios de blocos e

Tabela 2.8 - Requisitos da argamassa .............................................................. 33

Tabela 2.9 - Comportamentos mecânicos e fatores de eficiência ......................... 41

Tabela 2.10 - Influência do revestimento na resistência à compressão ................... 42

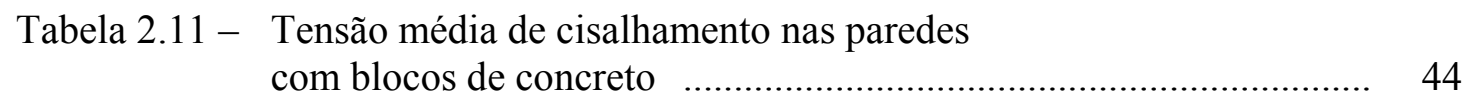

Tabela 2.12 - Processos de cura para concretos com abatimento nulo ................... 54

Tabela 2.13 - Tempo mínimo de cura (dias) ............................................................ 54

Tabela 2.14 - Consistência do concreto ................................................................... 56

Tabela 2.15 - Água de amassamento necessária .................................................... 57

Tabela 2.16 - Volume de agregado graúdo por metro cúbico de concreto ............. 57

Tabela 2.17 - Fator de correção de agregados graúdos ......................................... 57

Tabela 2.18 - Relação entre a relação água/cimento e resistência à compressão $\ldots 58$

Tabela $3.1-\quad$ Velocidades de carregamento ............................................................ 67

Tabela 4.1 - Características dos agregados utilizados para blocos de concreto e argamassa ....................................................... $\quad 75$

Tabela 4.2 - Estudo de traço para bloco de concreto ............................................... 79

Tabela 4.3 - Determinação da resistência característica à compressão dos blocos ….......................................................... $\quad 80$

Tabela 4.4 - Características dos traços de bloco de concreto ................................. 81

Tabela 4.5 - Determinação da absorção e massa específica ................................. $\quad 82$

Tabela 4.6 - Massas específica e unitária dos componentes da argamassa .......... 83

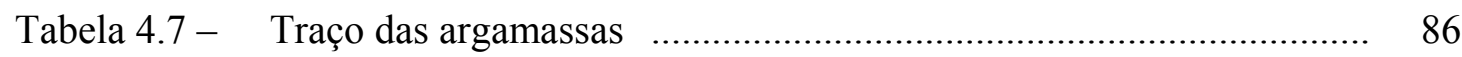


Tabela 4.8 - Características das argamassas _....................................................... 86

Tabela 4.9 - Coeficiente de não uniformidade .................................................... 92

Tabela 6.1 - Determinação da resistência característica à compressão do lote de blocos de concreto .................................... 102

Tabela 6.2 - Determinação do teor de umidade, absorção, área líquida e massa específica dos blocos

Tabela 6.3 - Resistência à compressão média de prismas e paredes, com e sem revestimentos

Tabela 6.4 - Correlações de eficiência entre as resistências à compressão das paredes e prismas em função da resistência característica à compressão do bloco …...................... 107

Tabela 6.5 - Correlações de resistência à compressão axial entre paredes e prismas, com e sem revestimentos

Tabela 6.6 - Resultado do ensaio de resistência à compressão de argamassa ...... 109

Tabela 6.7 - Módulo de deformação secante do bloco de concreto ....................... 110

Tabela 6.8 - Relação entre módulos de deformação do bloco, resultantes da relação entre parede / prisma

Tabela 6.9 - Módulo de deformação médio dos septos dos blocos ...................... 111

Tabela 6.10 - Resultados dos diferentes módulos de deformação para mesma curva tensão-deformação

Tabela 6.11 - Módulos de deformação das paredes, em função do tipo de agregado presente nas argamassas

Tabela 6.12 - Relação entre os módulos de deformação das paredes em função do tipo de agregado presente na argamassa ..................... 113

Tabela 6.13 - Módulo de deformação das argamassas .......................................... 116

Tabela 6.14 - Taxas de carregamento para o ensaio de aderência .......................... 117

Tabela 6.15 - Resistência de compressão das argamassas, referente ao ensaio de aderência à tração das argamassas de revestimento

Tabela 6.16 - Espessuras admissíveis de revestimentos e limites de resistência de aderência à tração para emboço com camada única 


\section{RESUMO}

FonseCA, F.B. (2002). Desempenho estrutural de paredes de alvenaria de blocos de concreto de agregados reciclados de rejeitos de construção e demolição. São Carlos, 2002. 140p. Dissertação (Mestrado) - Escola de Engenharia de São Carlos, Universidade de São Paulo.

Os rejeitos de construção e demolição representam, atualmente, grande volume de material desperdiçado no canteiro de obra e fábricas de pré-moldados de concreto. A necessidade da reciclagem para o desenvolvimento auto-sustentável, de materiais produzidos a partir dos rejeitos de construção, é de grande importância sob o impacto ambiental, além de proporcionar economia aos construtores e produtores de artefatos de cimento. Ensaios de concretos e argamassas, utilizando agregado reciclado, resultam bom desempenho mecânico e são relativamente mais leves quando comparados aos respectivos materiais utilizando agregados naturais. A fabricação de blocos de concreto com função estrutural, produzido com agregados reciclados de fração entre 2,4mm e 9,5mm, combinada à fração miúda de agregados naturais, possibilitam a execução de edifícios de pequena altura. A utilização da fração miúda reciclada, na preparação de argamassas de assentamento e revestimento, apresenta comportamento eficiente ao conjunto alvenaria-argamassa. A caracterização dos agregados, o estudo de traço, a análise do desempenho físico e mecânico dos blocos, prismas e paredes de alvenaria estrutural, bem como correlações de eficiência e análise da influência da argamassa de assentamento e de revestimento em relação à resistência de aderência à tração, é uma necessidade para o conhecimento e utilização deste material.

Palavras-chave: parede de alvenaria estrutural, aderência, agregado reciclado, bloco de concreto, argamassa de assentamento e revestimento. 


\section{ABSTRACT}

FONSECA, F.B. (2002). The structure performance of walls of masonry by concrete blocks of recycled aggregates and building and demolition rejects. São Carlos, 2002. 140p. Dissertação (Mestrado) - Escola de Engenharia de São Carlos, Universidade de São Paulo.

The building and demolilition rejects represent, nowadays, a great amount of wasted material in buildings and plants of pre-molded of concrete. The necessity of recycling for the self-supporting development of materials produced from the building rejects, is of great importance under the enviromental impact, and besides it provides savings for the builers and producers of concrete goods. Tests with concrete and mortar, utilizing recycled aggregate, show a good mechanical performance and they are lighter when compared to the respective materials using natural aggregate. The fabrication of concrete blocks with structural function, produced with recycled aggregate of fraction between $2,4 \mathrm{~mm}$ and $9,5 \mathrm{~mm}$, combined to the small fraction of natural aggregate, make possible the construction of low height buildings. The application of the recycled small fraction, in the preparation of foundation and revetment mortar, shows efficient employed with the set masonry-mortar. The aggregate characterization, the study of the proportion of ingredients for concrete, the analysis of the physical and mechanical performance of the blocks, prisms and walls of structural masonry, as well the correlations of efficiency and analysis of the influence of foundation and revetment mortar, relating to the resistence of adherence to traction, are necessities for the knowledge and utilization of this material.

Keywords: wall of structural masonry, adherence, recycled aggregate, concrete block, foundation and revetment mortar. 


\section{INTRODUCCÃO}

A busca por soluções que impliquem no aumento racional da produtividade e na eliminação de desperdícios é de fundamental importância para o desenvolvimento tecnológico e para o atual contexto imobiliário, uma vez que, na maioria dos edifícios residenciais, o investimento retorna após o término e a venda do produto.

Dentre o vasto conjunto de materiais, técnicas e metodologia construtiva, o processo que mais se destaca, que é mais antigo e que possui crescente interesse em empreendimentos imobiliários, devido à eficiência e à eficácia proporcionadas por uma edificação mais econômica, mais limpa e de elevada velocidade de construção, é o processo construtivo de alvenaria estrutural. No entanto, exige-se que o projeto seja bem definido e detalhado, não apenas em relação aos elementos estruturais e posicionamento geométrico, mas também em relação à execução, pois o assentamento da alvenaria deve ser realizado juntamente às instalações hidráulicas e elétricas, evitando contra-tempos, como: alterações e acréscimo nos gastos com mãode-obra, materiais e locação de equipamento; e garantindo desempenho e durabilidade dos materiais utilizados. 
Segundo BAYEUX (2000) em entrevista a Ercio Thomaz, o processo de racionalização nas construções não deve ser baseado na esbeltez dos elementos estruturais como lajes e paredes. Uma visão relativamente simplista de redução de espessura e eliminação da argamassa destinada ao assentamento nas juntas verticais das alvenarias, bem como a substituição dos revestimentos de argamassa por camadas finas de gesso, podem desencadear sérios problemas patológicos. Além disto, esta "pseudo-racionalização" possibilita comparar cada ambiente de um apartamento com um grande tambor, devido ao elevado nível de ressonância, transmissão termo-acústica e insegurança ao morador.

Porém, o mercado está sendo pressionado, pelas organizações não governamentais e instituições que se preocupam com a natureza, a procurar e utilizar materiais alternativos, evitando e eliminando a degradação ambiental. Após uma década de impasses, chegou à câmara dos deputados, um projeto de lei, elaborado por Emerson Kapaz, que tenta reunir propostas a serem implantadas à política nacional de resíduos sólidos (NOVAES, 2001). Dentre as propostas que devem ser realizadas até meados de 2004, as principais são: implantação de coleta seletiva de lixo nas cidades com mais de 100 mil habitantes e tarifa aos produtores de resíduos urbanos, seja lixo doméstico ou comercial, cuja arrecadação será aplicada em um fundo destinado à limpeza urbana. Quanto aos resíduos especiais, considerados prejudiciais à saúde e de difícil tratamento, a empresa fabricante fica responsável pelo produto, devendo retirá-lo do mercado após sua utilização, e podendo ser multada pelo governo caso não haja o cumprimento da lei. Um exemplo é o que ocorre no mercado de telefonia celular, pois as baterias, que contém metais pesados, são recolhidas pelos próprios produtores e armazenadas de forma criteriosa para não expor o material tóxico ao meio ambiente.

No que se refere à construção civil, não é difícil de encontrar caçambas de remoção de entulho e de outros materiais que não são utilizados diretamente no canteiro de obra, como materiais metálicos (pregos), celulósica (papelão), orgânica (restos de poda). Surge então a seguinte pergunta: qual a definição de entulho?

Segundo HAMASSAKI (2000): "Entulho é o conjunto de fragmentos e restos de tijolo, concreto, argamassa, aço, madeira, etc., provenientes do desperdício 
na construção, reforma e/ou demolição de estruturas, como prédios, residências e pontes", onde se subentende que "fragmento" é qualquer elemento pré-moldado, e "resto" é o material elaborado em obra que contem cimento, cal, areia ou brita.

Os resíduos gerados pelas construções e demolições (RCD), que podem ser caracterizados por produtos cerâmicos e produtos à base de cimento, pertencem a uma classe cujo destino encontra-se impróprio ao meio ambiente. Como não há um armazenamento apropriado, muitas vezes são depositados em aterros sanitários, ocupando considerável volume, sendo que geralmente são inertes ao meio ambiente. Por este motivo, o produto da reciclagem do RCD, denominado agregado reciclado obtido pela britagem do entulho, tem sido o assunto de muitas pesquisas, tanto na produção de novos concretos como argamassas.

Embora o conhecimento adquirido pelo uso de agregados reciclados de concreto seja extenso, a maioria destes estudos se refere apenas ao potencial do agregado, tornando-se superficiais, pois não pesquisam o comportamento do produto final. É lógico pensar que o elemento proveniente de um material de natureza desconhecida possua propriedades inferiores a um material convencional. No entanto, esta observação somente será verdadeira para algumas exigências do produto, desimpedindo que este material, vulgarmente denominado de "baixa qualidade", seja adequado quando utilizado para outro destino com a técnica correta.

Como muitas pesquisas empregam o agregado reciclado na produção de concretos com consistência plástica, surge um vasto campo, a ser estudado, destes materiais, quando se deseja utilizá-los com abatimento nulo. Além disto, com a falta de detalhes técnicos do desempenho estrutural de argamassas, contendo agregados de mesma origem, produzidas "in loco" e destinadas ao assentamento e ao revestimento de paredes, que poderão ocasionar séria patologia, surgem as seguintes perguntas: o agregado reciclado pode ser utilizado na fabricação de blocos estruturais de concreto, para que seja possível reduzir o custo das construções de unidades habitacionais? Qual seria o comportamento estrutural de uma parede, produzida com estes blocos, quando assentados e revestidos com argamassas contendo agregados naturais e reciclados de $\mathrm{RCD}$ ? 
Atualmente, a busca por concretos e argamassas duráveis é o principal objetivo dos programas de controle de qualidade em todo o país. Dentre a ação de agentes agressivos presentes no meio ambiente constituem a maior parte dos problemas patológicos na construção civil, o processo de carbonatação da pasta de cimento é o mais comum, devido à presença de dióxido de carbono, existente na atmosfera, ser o principal responsável pelo início do processo de deterioração, que possibilita a despassivação da armadura, facilitando o início do processo corrosivo. No entanto, este processo pode, em alguns casos, proporcionar à argamassa e ao concreto, a redução dos vazios presentes em sua estrutura, resultando no acréscimo de sua resistência, em decorrência de solubilização e lixiviação por presença de umidade.

\subsection{Objetivos}

O conhecimento científico permite compreender e formular hipóteses de determinado comportamento do material. Com este ideal, este trabalho teve dois objetivos principais:

a ) desenvolver um bloco vazado de concreto para alvenaria com função estrutural, composto por agregado reciclado miúdo e graúdo de RCD, mediante cura normal. Para que seja aceito em empreendimentos habitacionais, o bloco produzido deve possuir aparência esteticamente agradável, resistência característica mínima estrutural e índice de absorção inferior às normas prescritas;

b ) analisar os comportamentos físicos e mecânicos de painéis de alvenaria, através dos módulos de elasticidade e desempenhos de paredes quanto à resistência à compressão axial, além de obter as correlações de eficiência entre painéis, blocos, prismas. Com a disponibilidade de analisar a influência do revestimento de argamassa, sobre a resistência e o módulo de elasticidade da cada parede de alvenaria, assentada com determinado tipo de agregado (natural e reciclado) 
presente na argamassa, foram produzidas 3 séries de painéis, sendo um sem revestimento e dois com revestimentos de argamassas distintas. Ressalta-se que as argamassas com certo tipo de agregado, utilizadas para o assentamento, são as mesmas que revestem os painéis.

Com o objetivo de investigar o efeito da carbonatação nas juntas de argamassa de assentamento, foi analisada a influência do revestimento sobre a profundidade de argamassa carbonatada. Tal análise foi realizada com a mesma idade de execução dos ensaios de prismas e painéis de alvenaria, referente à compressão axial e módulo de elasticidade longitudinal.

\subsection{Justificativa}

\subsubsection{Agregados reciclados}

Com o grande crescimento do setor construtivo ocorrido a partir da segunda metade do século XX, juntamente com o término de vida útil das construções e do elevado índice de desperdício de material do canteiro de obra (fração das perdas que excede o limite mínimo característico da tecnologia), estimase que a taxa mundial anual de produção de entulho será de um bilhão de toneladas aproximadamente, ocupando considerável espaço, sem se referir aos custos com transporte e acondicionamento (LEVY, 1997).

Para solucionar este problema, existem inúmeros motivos que justificam e comprovam que os agregados provenientes de RCD e a utilização da alvenaria estrutural são os processos de racionalização mais indicados a projetos de construção de unidades habitacionais para prefeituras e construtoras, devido à economia proporcionada. 
Várias pesquisas concluíram que o material que entra e sai da obra como desperdício, corresponde de $20 \%$ a 30\% em massa. Segundo PINTO (1986), o predomínio de processos construtivos tradicionais e a falta de racionalização, implicam em perdas consideráveis de matéria-prima levada à obra. Na região de São Carlos, o índice médio de 0,9 ton de resíduos produzidos por metro quadrado, representa 13.000ton de entulho mensal.

Este índice, mesmo que antigo, eleva os gastos de remoção, seja pela prefeitura, seja por empresas responsáveis pela limpeza pública. Segundo a Logos Engenharia, responsável pelo gerenciamento do sistema de lixo e entulho na cidade de São Paulo, o custo da remoção para distâncias de até $10 \mathrm{~km}$ é de $\mathrm{R} \$ 22,81$ por tonelada, e para distâncias até $20 \mathrm{~km}$, o custo sobe para $\mathrm{R} \$ 24,72$ por tonelada (CORBIOLI, 1996).

BRITO FILHO (1999) cita que os serviços referentes à coleta, transporte e aterro, de despejos clandestinos em vias e logradouros públicos, custam à prefeitura de São Paulo R $\$ 4,5$ milhões por mês. E, segundo dados dos aterros oficiais do sistema de gerenciamento de resíduos sólidos urbanos da Prefeitura de São Paulo, são gerados mensalmente, aproximadamente $90.000 \mathrm{~m}^{3}$ de entulho de construção civil.

Com o propósito de reduzir o custo e utilizar este material, a prefeitura de Belo Horizonte instalou duas estações de recepção de entulho, que são responsáveis pelo seu recolhimento e transporte à usina de reciclagem de entulho do município. Com a confecção de produtos fabricados na própria fábrica, gera-se economia de $70 \%$ a $80 \%$ do custo destinado a construção civil municipal utilizando agregados convencionais, bem como a geração de empregos. BRITO FILHO (1999) cita que o custo para compra de areia natural é da ordem de $\mathrm{R} \$ 20,00 / \mathrm{m}^{3}$, enquanto que a reciclagem de entulho pode variar de $\mathrm{R} \$ 5,20 / \mathrm{m}^{3}$ a $\mathrm{R} \$ 7,80 / \mathrm{m}^{3}$. Além disso, pesquisas concluem que o custo de gerenciamento do entulho de uma metrópole, pode ser muito caro e de difícil controle, devido à possibilidade do transporte prejudicar o tráfego, ao passo que a implantação de uma usina de reciclagem de entulho, destinada à fabricação de produtos reciclados, pode resultar em uma economia de $75 \%$ no gerenciamento de entulho do município. 
$\mathrm{Na}$ cidade de Araraquara, as empresas de coleta de resíduos de construção e demolição, cobram de $\mathrm{R} \$ 25,00$ à $\mathrm{R} \$ 30,00$ a caçamba. Neste valor, já está incluso o transporte atualmente obrigatório até a Estação de Tratamento de Entulho da prefeitura de Araraquara, localizada a $12 \mathrm{~km}$ do centro da cidade. Segundo a Secretaria do Meio Ambiente de Araraquara, a usina que será implantada, está instalando um britador de impacto e um sistema de peneiramento com demanda de 100 ton/h. Além disso, a prefeitura deseja implantar uma cooperativa que se responsabilizará pela produção de blocos de concreto para alvenaria e de "adoquines" (pavimentos intertravados), cujos equipamentos para a produção serão doados pela prefeitura.

Outro fato importante é a necessidade da preservação do recurso mineral não renovável, pois em determinadas regiões como litoral e metrópoles, o agregado de qualidade apresenta-se escasso, sendo portanto, importado de jazidas distantes. Neste contexto, as pedreiras e portos de areia são obrigados a elevar o custo do agregado devido à dificuldade de encontrar locais apropriados à extração.

No entanto o despejo do entulho descartado das construções pode causar sérios problemas ao meio ambiente, em função do volume e do local despejado, mesmo sendo considerado praticamente inerte. Como as construtoras e empresas especializadas na limpeza urbana possuem responsabilidade e são fiscalizadas pelos órgãos municipais e organizações não governamentais, estas transportam o entulho aos aterros sanitários. Através da Tabela 1. 1, PINTO (1997) demonstra que o entulho produzido supera $50 \%$ da massa total dos aterros públicos de algumas cidades brasileiras.

Tabela 1.1 - Quantidade de entulho em relação ao total de resíduos em aterros públicos

\begin{tabular}{c||c}
\hline \hline \multicolumn{1}{c||}{ cidade } & quantidade (\% em massa) \\
\hline \hline Belo Horizonte & 51 \\
Brasília & 66 \\
Campinas & 64 \\
Jundiaí & 64 \\
Ribeirão Preto & 67 \\
Santo André & 62 \\
São José dos Campos & 68 \\
São José do Rio Preto & 60 \\
\hline \hline
\end{tabular}


Por outro lado, os demais consumidores de cimento, como particulares, produzem pouco volume de entulho, despejando-o clandestinamente nas vias públicas, terrenos baldios, margens de rios e nas periferias das cidades, segundo PINTO et al (1999) ${ }^{1}$. O problema do deposito clandestino não é apenas visual, mas sim maléfico à saúde pública pela proliferação de insetos, aracnídeos e roedores, possibilitando a transmissão de doenças e insegurança à população local, além de influir no mercado imobiliário. Dependendo do local de lançamento como terras baixas, junto a drenagens ou mesmo diretamente no leito de canais, os resíduos podem obstruir o escoamento, provocando inundações.

Acrescenta-se que a presença de elementos tóxicos ao entulho pode representar alta periculosidade. Como leigos na utilização de agrotóxicos, muitos usuários descartam as embalagens de maneira inadequada. Segundo Cosmo (2001), o lixão de Goioerê, município do Centro-Oeste do estado do Paraná, está sendo utilizado como depósito para milhares de embalagens de agrotóxicos, possibilitando a contaminação do meio ambiente através do lençol freático e da fumaça tóxica expelida pela incineração.

Segundo CorbiOli (1996) em entrevista a Tarcísio Pinto: "Se a questão é redução de custos, o ideal é que a reciclagem seja somada a outras formas de economizar. Não existe nenhuma solução mágica. A maioria dos processos, como a adoção de laje zero, fôrmas pré-fabricadas ou a aplicação do gesso diretamente sobre os blocos, é essencial para reduzir os custos e a quantidade de material desperdiçado. A reciclagem entra como uma forma de reaproveitar o que é inevitavelmente perdido. O planejamento é o que torna o projeto de reciclagem eficiente". Ou seja, por mais que se tente otimizar o sistema construtivo e minimizar o desperdício através de diversos mecanismos, a reciclagem torna-se um meio de reaproveitar este material que certamente é perdido.

\footnotetext{
${ }^{1}$ PINTO, A.R. et al. (1999). Problemas ambientais de resíduos da construção civil e usina de reciclagem de Ribeirão Preto. São Carlos. CETEPE. 1 cassete VHS, 14min. Color. Som. I Trabalho apresentado à disciplina "Gerenciamento de Resíduos sólidos", Departamento de Hidráulica e Saneamento, EESC-USP/
} 


\subsubsection{Racionalização na construção}

A utilização da alvenaria estrutural como principal elemento portante de edificações, possibilita além da redução no custo final da edificação, rapidez no processo construtivo, ausência de desperdícios, processo totalmente controlado, sem surpresa em custos e bom desempenho às solicitações. Conforme BAYEUX (2000), a utilização destes elementos pré-moldados permite contrariar a tradição de execução das instalações: eliminando cortes e rasgos às paredes após a elevação da alvenaria e o canteiro de obra torna-se um local mais limpo.

As maiores vantagens do sistema de racionalização, promovidas pela alvenaria estrutural, são a eliminação das fôrmas e cimbramentos para a construção da estrutura, e a redução do consumo de aço nas armaduras, as quais são utilizadas nas amarrações para resistir às solicitações de cisalhamento e tangenciais. Segundo a Companhia de Desenvolvimento Habitacional e Urbano do Estado de São Paulo CDHU, a obra ganha mais velocidade, precisão dimensional e capricho no acabamento (PIGNANELLI, 2000). Devido às exigências das normas técnicas quanto às tolerâncias dimensionais dos blocos de alvenaria, a parede resulta em um elemento uniforme, permitindo revestimento com menor espessura, eliminando desta forma, algumas patologia típicas.

Devido à queda nas unidades residenciais licenciadas, o processo construtivo tradicional no Rio de Janeiro encontra-se em decadência (ÍNDICE, 2001). Conforme indica a Figura 1.1, de uma pesquisa realizada pelo SINDUSCON-RJ, supõese que as construtoras possuem elevado custo na construção do imóvel devido ao desperdício, que é repassado, juntamente com a margem de lucro, ao mercado consumidor. Com a expansão dos novos conhecimentos tecnológicos, a alvenaria estrutural possibilita obter rapidamente, o retorno do investimento, uma vez que, reduzindo o desperdício e aumentando a velocidade de execução, diminui-se o tempo de locação de equipamentos e o custo da mão-de-obra. 


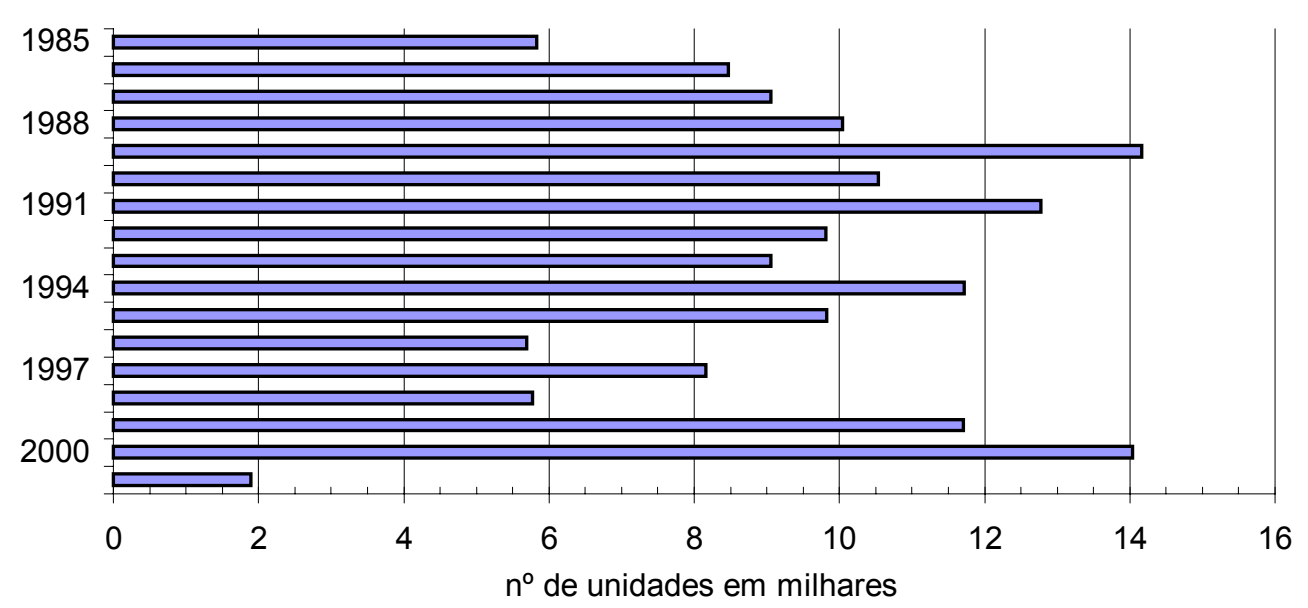

Figura 1.1 - Unidades residenciais licenciadas no mesmo período FONTE: Í́NDICE (2001)

LUNA (2001) cita que outro fator importante que influencia nesta queda é a falta de financiamento na área habitacional, proveniente de empresas privadas ou públicas, resultando na dificuldade de construção de imóveis. Desta forma, o custo final se eleva, provocando, conseqüentemente, queda na demanda e na produção, tornando-se um círculo vicioso. No entanto, o financiamento habitacional popular seria a melhor forma, não esquecendo que incentivos imobiliários, como o chamado “projeto de habitação 1.0”, seria uma alternativa a curto prazo para solucionar o atual déficit de aproximadamente 6 milhões de moradias. A Figura 1. 2 ilustra a casa doada à prefeitura da cidade de Serra Negra-SP pela ABCP.

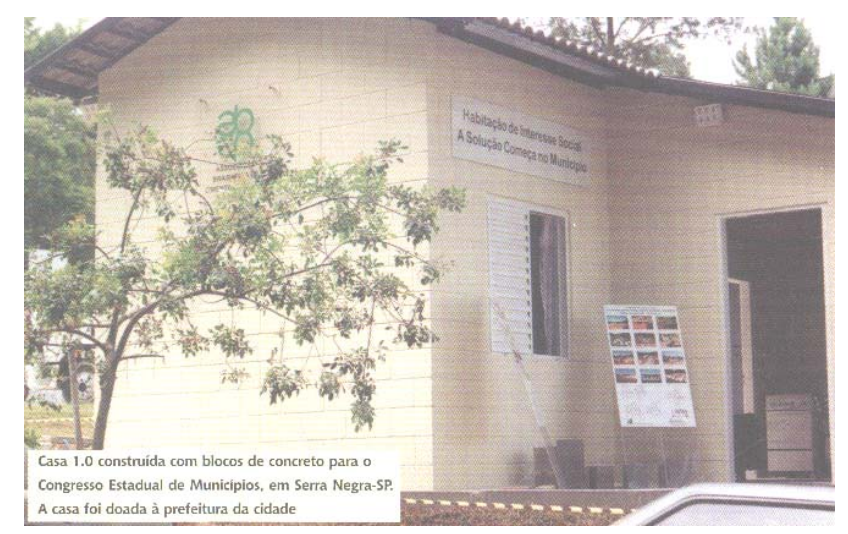

Figura 1.2 - Casa 1.0 construída com blocos de concreto FONTE: REVISTA PRISMA, $2002^{2}$

\footnotetext{
${ }^{2}$ ReVISTA PrISMA, São Paulo, no², p.27, março, 2002
} 


\subsection{Apresentacão $\underline{\text { do }} \underline{\text { trabalho }}$}

Dentro do contexto da possibilidade de produzir blocos de concreto e argamassas de assentamento e revestimento com agregados reciclados, analisando o desempenho mecânico, este trabalho está dividido da seguinte forma:

No Capítulo 2 expõe-se a revisão bibliográfica referente aos agregados reciclados; ao estudo de paredes alvenaria com função estrutural; à técnica da produção de concretos com abatimento nulo para estruturas pré-moldadas e ao processo de carbonatação que pode ocorrer na pasta de cimento.

O Capítulo 3 apresenta a metodologia de desenvolvimento dos traços de concreto e de argamassa, bem como a descrição dos ensaios realizados com paredes, prismas, blocos e argamassas. Além disto, relata-se a obtenção dos agregados reciclados utilizados na pesquisa.

O Capítulo 4 descreve o desenvolvimento e a escolha de traços de argamassas e concretos contendo agregados reciclados, destinados à produção dos blocos e argamassas, além do processo de fabricação dos blocos de concreto, e da obtenção e análise dos agregados reciclados de RCD.

A produção de blocos de concreto e a confecção de paredes e prismas de alvenaria apresentam-se no Capítulo 5, juntamente com detalhes pertinentes aos mesmos.

No Capítulo 6, apresentam-se a análise e a discussão dos resultados obtidos no estudo experimental, procurando-se comentar os fatores que condicionam a durabilidade e o desempenho das paredes com e sem revestimento.

As conclusões finais sobre os tópicos abordados nesta pesquisa encontram-se no Capítulo 7, dando ênfase na influência do desempenho do revestimento sobre as paredes, juntamente com o avanço da carbonatação. Por fim, são feitas sugestões para possíveis pesquisas complementares. 


\section{意 2 REVISÃO BIBLIOGRÁFICA}

O processo de pré-fabricação é fruto de um grande esforço dos profissionais da construção civil, aliada ao desenvolvimento humano, tendo a capacidade para melhorar as condições de trabalho com uma significativa racionalização que resulta na economia, no aumento da produtividade e da qualidade do material. No entanto, é de praxe que todo novo elemento fabricado pela indústria, seja analisado pelos seguintes parâmetros: materiais a serem utilizados e exigências técnicas a serem satisfeitas pelo elemento para obter o estimado desempenho do produto final.

Com o ideal de produzir e analisar o desempenho de um novo componente estrutural, este capítulo relata uma parcela do atual conhecimento e técnica de fabricação, referentes aos agregados reciclados, aos componentes que caracterizam o desempenho da alvenaria estrutural, à fabricação de pré-moldados de concreto com abatimento nulo, e aos eventuais processos químicos que têm a capacidade de modificar o comportamento dos produtos que contém agregados reciclados de $\mathrm{RCD}$. 


\subsection{Agregados reciclados}

Antigamente, a principal hipótese sobre os agregados naturais era que estes não reagiam com as partículas de cimento, tornando-se um sólido que apenas proporcionava resistência mecânica, não interferindo nas demais características físicas. No entanto, novos materiais surgiram no mercado com a função de serem utilizados como agregados, como a argila expandida e o isopor floculado para produção de concretos e argamassas com menor densidade. Desta forma, NEVILLE (1997) define o agregado para material de construção como sendo um sólido, não totalmente inerte, porém coesivo em contato com a pasta de cimento, cujas propriedades físicas, térmicas e químicas influenciam no desempenho mecânico do concreto.

Em geral, a resistência e o módulo de elasticidade do concreto dependem da composição química, textura, formato geométrico, resistência mecânica e estrutura mineral do agregado. Além disso, o desempenho do concreto também pode ser influenciado pela capacidade de absorção de água e pela aderência da pasta na superfície do agregado. Desta forma, o agregado reciclado deve ser estudado, analisando-se suas características físicas, pois, segundo ANGULO (2000), a variabilidade dos agregados de RCD ocorre em função do cronograma de execução de serviços, fazendo com que, em cada período, os materiais e índices de perdas sejam bem diferentes.

Segundo SIMPÓSIO $(1999)^{3}, 71 \%$ das empresas brasileiras atuam na atividade de construção e incorporação (Figura 2. 1), cuja classificação das empresas de micro, pequeno, médio e grande porte correspondem a $14 \%, 50 \%, 21 \%$ e $14 \%$, respectivamente, do setor da construção civil.

${ }^{3}$ Simpósio NACIONAL. DeSPERdício DE MATERIAIS NOS CANTEIROS DE OBRAS: A QUEDA DO MITO, 1999, São Paulo (1999). Anais. São Paulo, Departamento de Engenharia de Construção Civil, Escola Politécnica da Universidade de São Paulo, 48p. 

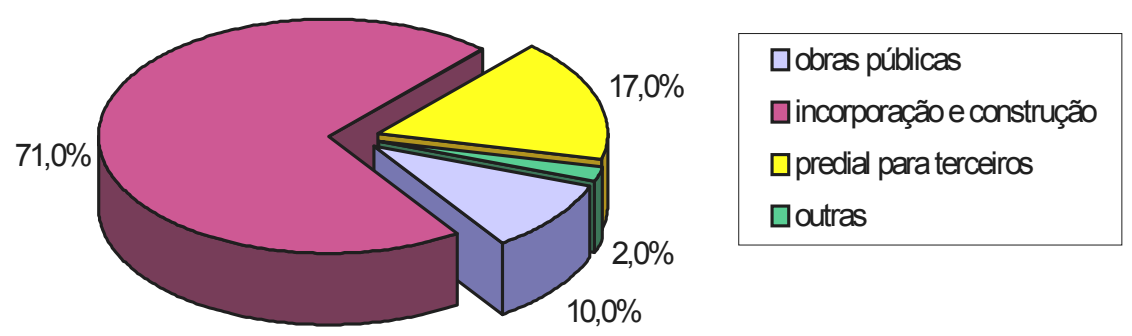

Figura 2.1 - Principal atividade da empresa

FONTE: SIMPÓSIO, 1999

Outro fator importante é a porcentagem de perda em função do tipo da natureza do material. A Figura 2. 2 apresenta os resultados extraídos de amostras de 69 obras espalhadas pelo país. Nota-se que 78,8\% dos materiais presentes nesta pesquisa (argamassas, concretos, agregados naturais convencionais, cimento, blocos, tijolos e placas cerâmicas), podem ser destinados ao processo de reciclagem. Subentende-se que a elevada taxa de cimento seja desperdiçado nos pequenos canteiros de obras, cuja ausência do acompanhamento técnico do engenheiro possibilite ao pedreiro determinar a quantidade acima do necessário.

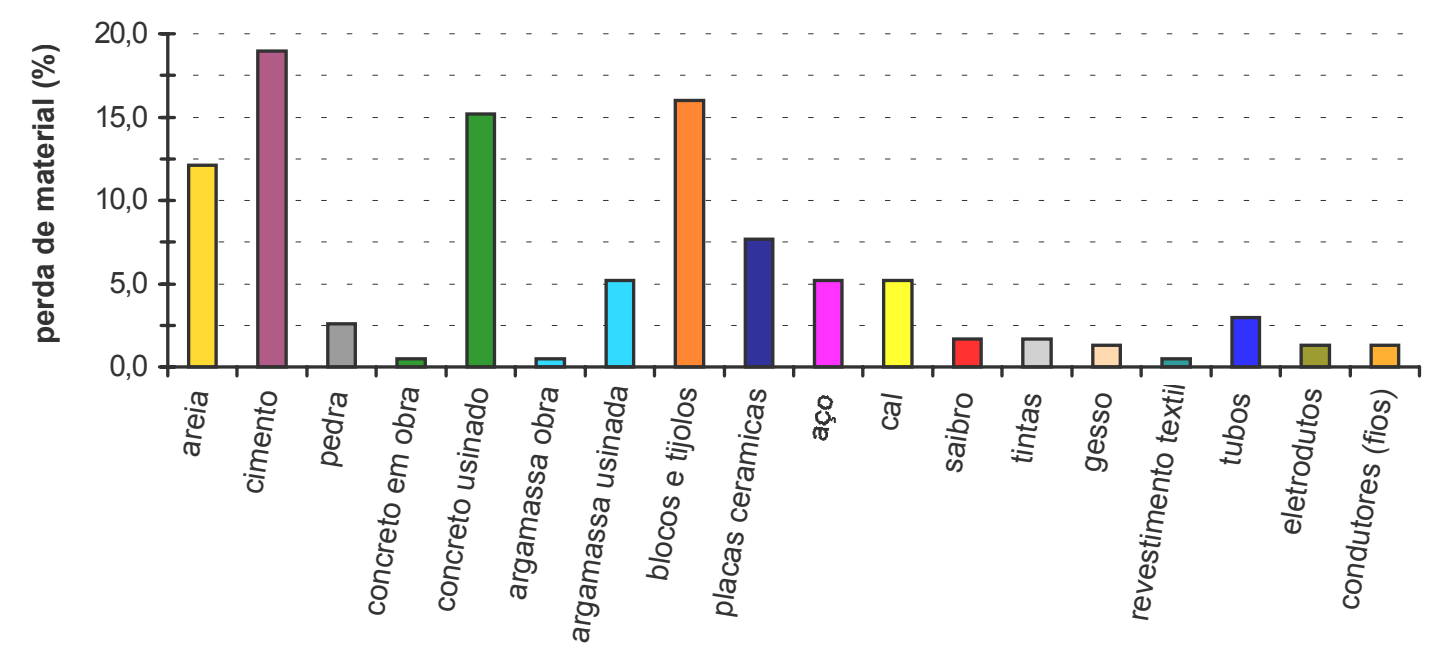

Figura 2.2 - Perda de material

FONTE: SIMPÓSIO, 1999

\subsubsection{Aplicação}

Vários são os exemplos que se encontram no meio técnico. Segundo MeHTA (1994), em 1983 e 1984, uma das rodovias mais antigas e movimentadas no 
estado de Michigan, EUA, tornou-se a primeira rodovia de grande porte a utilizar o agregado reciclado originário da própria seção da pista, na recuperação de 44,6km de extensão, devido à mesma estar deteriorada.

CAmargo (1995) cita que as duas usinas de reciclagem do município de Belo Horizonte produzem agregados reciclados correspondentes a $4 \mathrm{~km}$ de sub-base de vias por mês, equivalente a 920 casas populares com $40,0 \mathrm{~m}^{2}$.

Contudo, DE PAUW ${ }^{4}$ apud LEVY (1997) menciona experiências negativas com concreto de RCD na Bélgica, onde duas pontes tiveram de ser demolidas, possivelmente devido ao desenvolvimento das reações álcali-agregado, cuja anomalia é resultado da fragmentação do concreto.

Por este motivo, os agregados reciclados são restritos nas utilizações. A grande variedade destes resíduos, resulta em uma qualidade inferior quando comparado aos agregados convencionais, pois o entulho pode apresentar características não homogêneas em sua natureza e grandes variações em relação à resistência e em outras propriedades. As características físicas dos agregados, como densidade, resistência mecânica, volume, formato geométrico, tamanho e distribuição de poros, segundo MEHTA (1994), são os principais responsáveis pelas propriedades no estado endurecido do concreto, como massa unitária e específica, módulo de elasticidade, e resistência à tração e compressão. Portanto, recomenda-se que a utilização destes agregados sem o devido conhecimento periódico de suas características, seja destinada a elementos de concreto sem função estrutural, como por exemplo: blocos de concreto de vedação, obras de pavimentação, guias e sarjetas, regularização e cascalhamento de ruas de terra, obras de drenagem, execução de contrapisos, contenção de encostas com sacaria de entulho-cimento, pavimentação para tráfego leve (calçada), e outros.

\footnotetext{
${ }^{4}$ De Pauw, C.;Desmyter, J.; Dessel, J.V. (1986) Reuse of construction and demolition waste as aggregates in concrete, technical and anviromental aspects. IN: CONCRETE IN THE SERVICE OF MANKIND. INTERNATIONAL CONFERENCE CONCRETE FOR ENVIROMENT ENHANCEMENT AND PROTECTION, Dundee - Escócia. Proceedings. Ravindra \& Thomas. Grã Bretanha, p.131-140.
} 


\subsubsection{Características físicas dos agregados reciclados}

A seleção dos agregados deve ser feita cuidadosamente porque, à medida que o valor da resistência à compressão do concreto e argamassa aumenta, os agregados podem se tornar o elo fraco.

Ao analisar as características físicas dos reciclados, LATTERZA (1998) verificou que os agregados graúdos reciclados, retirados de uma amostra em janeiro de 1997, podem ser considerados agregados relativamente mais leves se comparados aos naturais, conforme indica a Tabela 2. 1. A presença de argamassa aderida, o formato geométrico do agregado e a presença de materiais cerâmicos foram os principais responsáveis pela redução de massa unitária e específica.

Tabela 2.1 - Características físicas dos agregados

\begin{tabular}{c||c|c}
\hline \hline características físicas & natural & reciclado \\
\hline \hline massa unitária no estado solto $\left(\mathrm{kg} / \mathrm{dm}^{3}\right)$ & 1,44 & 1,10 \\
massa unitária no estado seco compactado $\left(\mathrm{kg} / \mathrm{dm}^{3}\right)$ & 1,56 & 1,27 \\
massa específica $\left(\mathrm{kg} / \mathrm{dm}^{3}\right)$ & 2,88 & 2,45 \\
\hline \hline
\end{tabular}

FONTE: LATTERZA, 1998

O formato final do agregado pode ser ou anguloso ou lamelar (espessura é pequena em relação às demais dimensões), dependendo do material presente no $\mathrm{RCD}$, e do equipamento de britagem utilizado, que poderá aumentar a superfície específica dos agregados com formato irregular, resultando em uma maior quantidade de argamassa e pasta de cimento a ser aderida.

Analisando a forma dos grãos originários de tijolos e blocos, KRUMBEIN \& SLOSS (1963) compararam a esfericidade e o arredondamento, possibilitando analisar o melhor empacotamento entre grãos dos agregados que resulta em concretos e argamassas mais coesas, conforme Tabela 2. 2.

Tabela 2.2 - Esfericidade e arredondamento característicos dos agregados

\begin{tabular}{c||c|c}
\hline \hline material & esfericidade & arredondamento \\
\hline \hline areia natural & $0,9-0,7$ & $0,7-0,5$ \\
tijolo & $0,7-0,5$ & $0,7-0,5$ \\
bloco cerâmico & $0,5-0,3$ & $0,5-0,3$ \\
bloco de concreto & $0,9-0,7$ & $0,7-0,5$ \\
\hline \hline
\end{tabular}

FONTE: KRUMBEIN \& SLOSS (1963) 
A esfericidade, segundo KENITIRO $(1973)^{5}$, é a grandeza que tenta expressar numericamente o grau de aproximação de forma de uma partícula qualquer, com aquela de esfera perfeita. Em relação ao arredondamento, MENDEL et al. $(1972)^{6}$ define como sendo o grau de agudeza das arestas e cantos da partícula, independendo se sua forma, isto é, a curvatura média e seus cantos e arestas. A Figura 2. 3 possibilita comparar visualmente o grau de arredondamento e de esfericidade: quanto maior o grau de esfericidade, menos alongada é a amostra; quanto maior o arredondamento, mais lisa é a amostra. Logo, quanto mais próximo do valor unitário, melhor será o empacotamento da amostra.

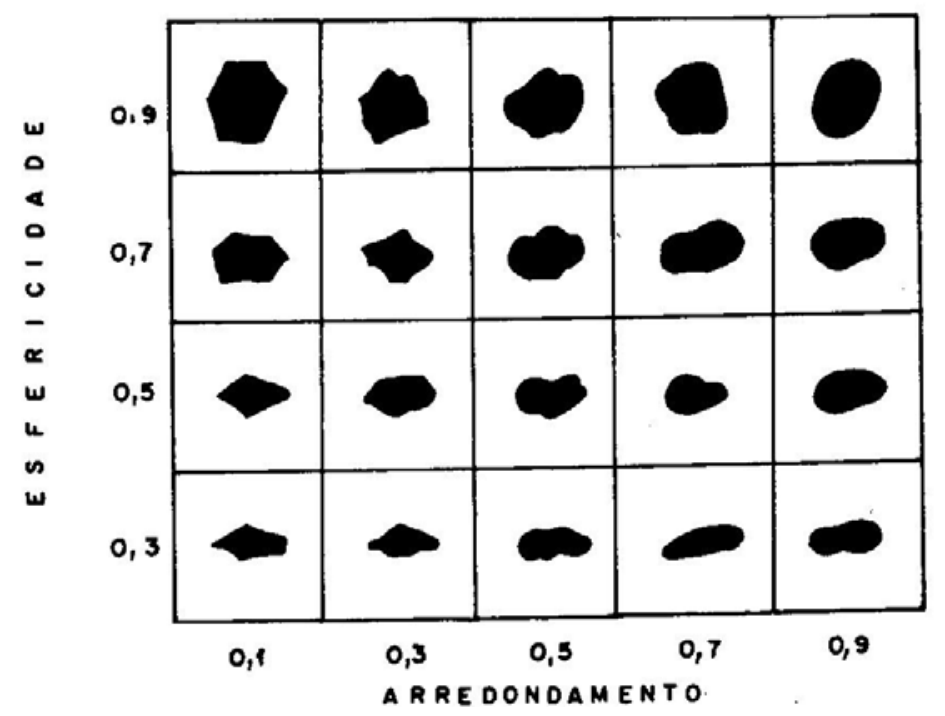

Figura 2.3 - Comparação visual de arredondamento e esfericidade do grão de areia

FONTE: KRUMBEIN \& SLOSS (1963)

Segundo Wadell $(1973)^{7}$, a esfericidade pode ser determinada empiricamente pela Equação 2. 1.

${ }^{5}$ KenitiRo, S. (1973). Introdução à sedimentologia. São Paulo. Edgard Blücher, Editora da Universidade de São Paulo.

${ }^{6}$ Mendes, J.C.; Bigarella, J.J.; SAlamuni, R. (1972). Estratigrafia e sedimentologia; geologia estrutural, aerofotogeometria. Brasília, Instituto nacional do livro.

${ }^{7}$ WADELL, H. (1933). Sphericity and roundness of quartz particles. Journal of Geology, 41. p.310-331. 


$$
\text { esfericidade }=\sqrt[3]{\frac{\mathrm{V}_{\text {partícula }}}{\mathrm{V}_{\text {esfera }}}}
$$

Onde:

$\mathrm{V}_{\text {partícula }}$ : volume do grão do agregado analisado

$\mathrm{V}_{\text {esfera }}$ : volume da esfera circunscrita ao grão do agregado

\subsubsection{Argamassa aderida no agregado reciclado}

Ao analisar a influência de argamassa aderida presente nos agregados, HANSEN (1992) concluiu que a diminuição da dimensão dos agregados reciclados (R) aumenta o volume de argamassa aderida ao agregado natural $(\mathrm{N})$, conforme mostra a Tabela 2. 3. Além disso, quanto maior a densidade, menor a absorção.

Tabela 2.3 - Influência da argamassa aderida

\begin{tabular}{|c|c|c|c|c|c|}
\hline $\begin{array}{l}\text { dimensão do } \\
\text { agregado (mm) }\end{array}$ & \multicolumn{2}{|c|}{ massa específica $\left(\mathrm{g} / \mathrm{cm}^{3}\right)$} & \multicolumn{2}{|c|}{$\overline{\text { absorção (\%) }}$} & $\begin{array}{c}\text { volume de argamassa aderida (\%) } \\
\mathrm{R}\end{array}$ \\
\hline $4-8$ & 2,50 & $2,34-2,35$ & 3,7 & $8,5-8,7$ & $\overline{58-64}$ \\
\hline $8-16$ & 2,62 & $2,42-2,45$ & 1,8 & $5,0-5,7$ & $38-39$ \\
\hline $16-32$ & 2,61 & $2,48-2,49$ & 0,8 & $3,7-4,0$ & $25-35$ \\
\hline
\end{tabular}

FONTE: HANSEN, 1992

Esta quantidade de argamassa aderida aos agregados reciclados de concreto influencia na absorção de água, conforme pode ser visto na Figura 2. 4. Segundo QUeBAud \& BUYLE-BodiN ${ }^{8}$ apud ANGUlo (2000), outro fato importante é o efeito da relação água/cimento, cujo aumento possibilita que a absorção de água seja maior nos agregados de menor dimensão.

8 Quebaud, M.R.; Buyle-Bodin, F. (1999). A reciclagem de materiais de demolição utilização dos agregados reciclados no concreto. IN: CONGRESSO BRASILEIRO DE CIMENTO, 5. São Paulo. Anais. São Paulo, 14p. 


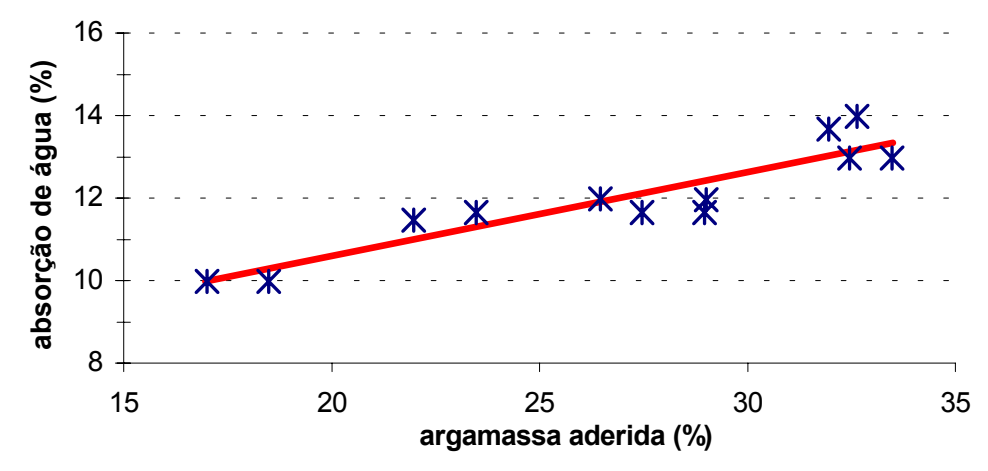

Figura 2.4 - Correlação entre a quantidade de argamassa aderida aos grãos e a absorção de água dos agregados reciclados de concreto

FONTE: QUEBAUD \& BUYLE-BODIN apud ANGULO, 2000

A argamassa aderida na superfície do agregado reciclado é responsável por algumas diferenças nas propriedades entre os agregados reciclados e os naturais. Segundo GONÇALVES (2001), esta camada influencia desde as propriedades do próprio agregado, até as do concreto no estado fresco ou endurecido. Desta forma, é possível que a aderência da pasta de cimento ao agregado reciclado, dependa em parte, mais das propriedades físicas da superfície (rugosidade e porosidade) do agregado de RCD que das propriedades químicas do aglomerante, ou seja, nos agregados de RCD, a aderência ocorre devido ao intertravamento mecânico e das reações químicas do aglomerante e pozolânica, devido à elevada presença de cerâmica vermelha, enquanto que a aderência mais provável da pasta de cimento ao agregado natural possa ser de caráter químico.

Ao comparar as características dos agregados naturais e reciclados utilizados nas construções, QUEBAUD (1999) verificou que os agregados reciclados contêm em média $30 \%$, em massa, de pasta de cimento e que os agregados de RCD têm uma porosidade mais importante, pois a absorção de água desses agregados é bem maior, reduzindo conseqüentemente sua densidade e sua resistência. Esta elevada capacidade de absorver água representa a permeabilidade do material em relação à água e gases, que são os principais fatores que ativam a reatividade das impurezas, prejudicando a durabilidade do elemento. Além disso, ao analisarem a permeabilidade, concluíram que a porosidade é decorrente da temperatura de secagem, conforme Figura 2. 5. 


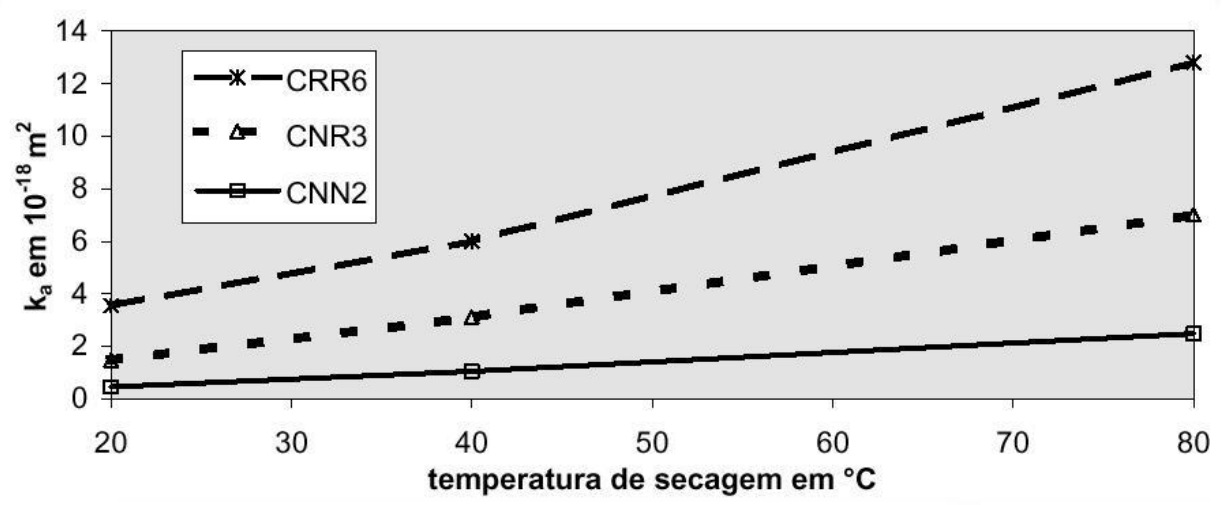

Figura 2.5 - Influência da secagem na permeabilidade dos concretos FONTE: QUEBAUD et al., 1999

\subsubsection{Influência do consumo de cimento}

Segundo ZORDAN et al. (1999), concretos contendo agregados reciclados possuem maior resistência à compressão que agregados convencionais, para consumos superiores a 1:6,4 da relação cimento/agregado da mistura, conforme exposto na Figura 2. 6, cuja resistência está expressa pela Equação 2. 2.

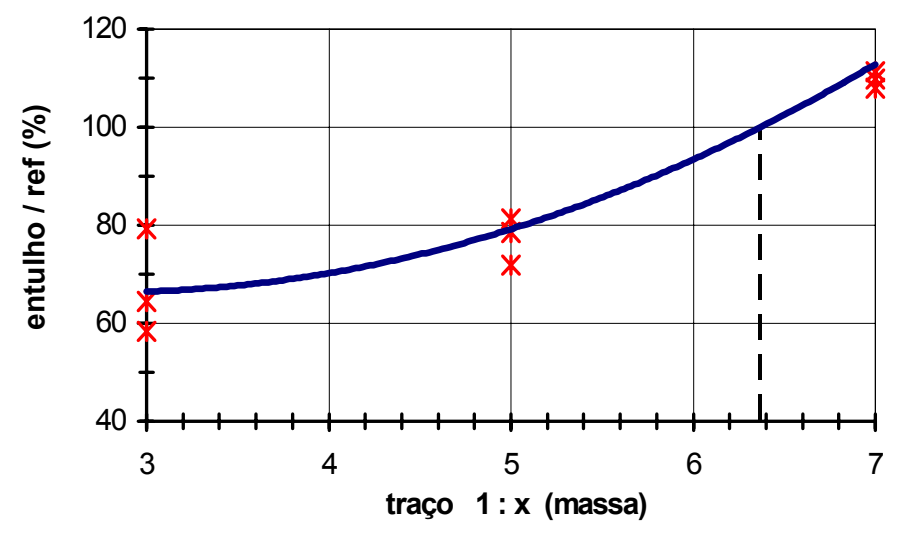

Figura 2.6 - Resistência à compressão $x$ consumo de cimento

FONTE: ZORDAN et al., 1999

$$
\frac{\text { entulho }}{\text { referência }}=\frac{\mathrm{fc}_{\text {entulho }}}{\mathrm{C}_{\text {entulho }}} / \frac{\mathrm{fc}_{\text {referência }}}{\mathrm{C}_{\text {referência }}}
$$

Onde:

$\mathrm{f}_{\mathrm{c}}$ : resistência à compressão do concreto produzido;

C: consumo de cimento do concreto 


\subsubsection{Absorção de água dos agregados reciclados}

Ao estudar as propriedades do concreto, produzido com agregado reciclado, no estado endurecido, LATTERZA (1998) percebeu que mantendo a relação água/cimento, o abatimento diminui quando substitui-se o agregado natural pelo agregado reciclado. E mesmo que se aumente esta relação, pode-se obter ainda um concreto sem abatimento, devido à elevada absorção do agregado reciclado. Este fato pode promover resistências médias mais altas, se comparadas aos corpos-de-prova contendo agregado natural, conforme Tabela 2. 4, quando empregados todos os agregados graúdos reciclados, com dimensão máxima igual a 9,5mm.

Tabela 2.4 - Resultados dos ensaios de verificação de resistência

\begin{tabular}{c||c||c||c|cc|c}
\hline \hline \multicolumn{1}{c||}{$\begin{array}{c}\mathrm{D}_{\max } \\
(\mathrm{mm})\end{array}$} & $\begin{array}{c}\text { tipo de } \\
\text { agregado }\end{array}$ & a/c & abatimento & \multicolumn{4}{c}{ resistência (MPa) } \\
& & $(\mathrm{mm})$ & \multicolumn{2}{c}{ compressão } & tração indireta \\
& & & & 7 dias & 28 dias & 28 dias \\
\hline \hline \multirow{2}{*}{19,0} & natural & 0,68 & 13 & $15,4(1,00)$ & $21,8(1,00)$ & - \\
& $100 \%$ reciclado & 0,83 & 15 & $13,2(0,86)$ & $18,5(0,85)$ & - \\
\hline \multirow{2}{*}{9,5} & natural & 0,68 & 18 & $15,2(1,00)$ & $22,3(1,00)$ & $2,59(1,00)$ \\
& $50 / 50$ & 0,68 & 10 & $19,2(1,26)$ & $29,0(1,30)$ & $2,85(1,10)$ \\
& $100 \%$ reciclado & 0,74 & 0 & $18,2(1,20)$ & $27,0(1,21)$ & $2,72(1,05)$ \\
\hline \hline
\end{tabular}

FONTE: LATTERZA, 1998

Os agregados reciclados de RCD, constituídos por argamassa, cerâmica vermelha e concreto, são muito porosos em relação aos agregados naturais devido aos microporos existentes na pasta de cimento e na argila. Logo, estes agregados possuem elevada capacidade de absorção de água, influenciando na trabalhabilidade da mistura no estado fresco. Caso não seja corrigido adequadamente, poderão surgir sérias patologias decorrentes da falta ou excesso de água.

Com esta preocupação, LATTERZA (1998) determinou as curvas de perda de abatimento para concretos em relação à primeira leitura, com agregados com diâmetro máximo de 9,5mm e $19 \mathrm{~mm}$ respectivamente, conforme Figura 2. 7. Nota-se que as inclinações das curvas contendo agregado reciclado foram bem mais acentuadas, indicando uma perda de abatimento mais rápida. Isto significa que os concretos e argamassas confeccionados com substituição total ou parcial do agregado natural pelo reciclado, apresentam menor tempo de trabalhabilidade, devido à influência da absorção de água pelo agregado reciclado no estado fresco do concreto. 


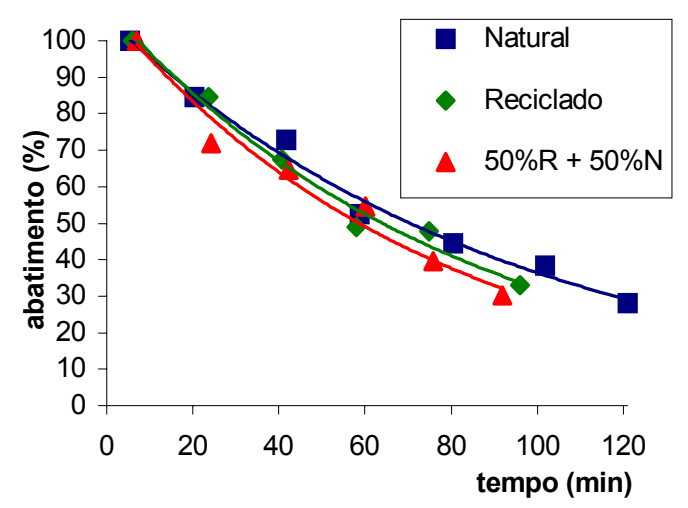

$4,8 \mathrm{~mm}<\mathrm{D}<9,5 \mathrm{~mm}$

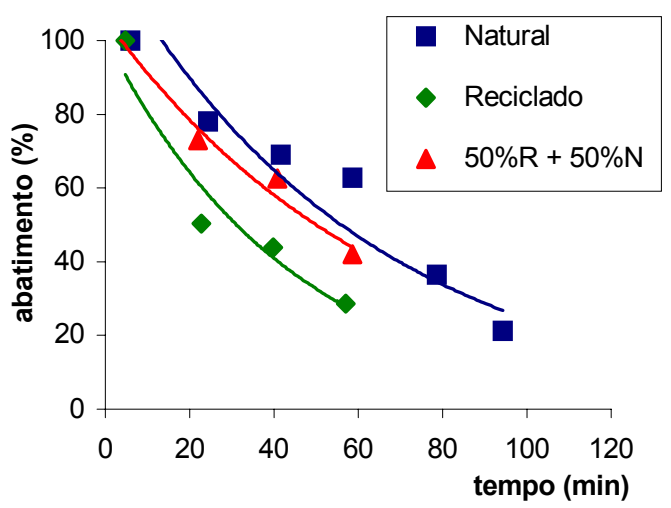

$9,5 \mathrm{~mm}<\mathrm{D}<19,0 \mathrm{~mm}$

Figura 2.7 - Curvas de perda do abatimento de concretos com agregados graúdos de graduação $D_{\text {máx }}=9,5$ e $19,0 \mathrm{~mm}$

FONTE: LATTERZA, 1998

A quantidade de água, utilizada para a mistura, que proporciona trabalhabilidade dos materiais e a reação química com as partículas de cimento, é classificada, segundo LIBORIO (2001), com base no grau de dificuldade de sua remoção no estado endurecido, conforme Tabela 2. 5.

Tabela 2.5 - Classificação da água presente na pasta de cimento

\begin{tabular}{|c|c|c|}
\hline classificação da água & característica & remoção \\
\hline quimicamente combinada & $\begin{array}{l}\text { reage com a estrutura dos compostos } \\
\text { hidratados de cimento }\end{array}$ & por aquecimento \\
\hline interlamelar & $\begin{array}{l}\text { em formato de gel, está associada à } \\
\text { estrutura do silicato de cálcio hidratado } \\
\text { e ligada por pontes de hidrogênio }\end{array}$ & $\begin{array}{l}\text { umidade relativa inferior a } 11 \% \text {, } \\
\text { provocando a retração do } \\
\text { silicato de cálcio hidratado }\end{array}$ \\
\hline água livre & $\begin{array}{l}\text { vazios grandes com diâmetro maior } \\
\text { que } 0,05 \mu \mathrm{m}\end{array}$ & $\begin{array}{l}\text { facilmente retirada com umidade } \\
\text { relativa abaixo de } 100 \%\end{array}$ \\
\hline água retida & $\begin{array}{l}\text { pequenos capilares com diâmetro de } \\
0,005 \mu \mathrm{m} \text { a } 0,05 \mu \mathrm{m} \\
\end{array}$ & $\begin{array}{l}\text { sua remoção causa a retração } \\
\text { do sistema }\end{array}$ \\
\hline adsorvida & $\begin{array}{l}\text { próxima à superfície do sólido, fica } \\
\text { retida pelas forças superficiais das } \\
\text { partículas do gel }\end{array}$ & $\begin{array}{l}\text { umidade relativa do ar abaixo de } \\
30 \% \text {, provocando a retração por } \\
\text { secagem }\end{array}$ \\
\hline
\end{tabular}

FONTE: LIBORIO, 2001

No entanto, MeHTA (1994) menciona que, no estado fresco, outra parcela de água da mistura pode ser succionada pelos agregados porosos, cujo processo de absorção apresenta-se na Figura 2. 8. 


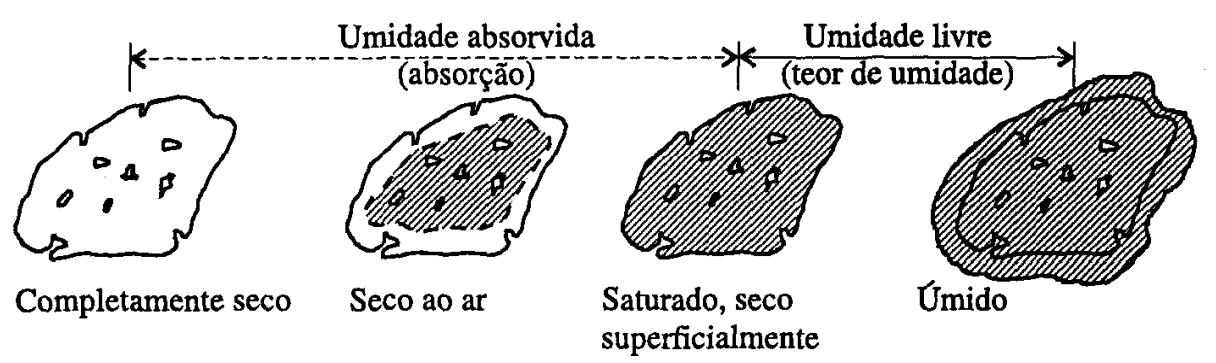

Figura 2.8 - Processo de absorção de água do agregado

FONTE: MEHTA, 1994

Segundo LEITE et al. (2000), este aumento de absorção ocorre devido à existência de porosidade e à elevada área superficial das partículas finas de argila e do material cimentício. Além da granulometria, a composição básica do RCD tem influência na capacidade de absorver água do agregado reciclado. Os métodos propostos pela NBR 9777/87 e NBR 9937/87, referentes à determinação de absorção de agregados miúdos e graúdos, respectivamente, são apropriados para agregados naturais, pois estes podem ser considerados impermeáveis, entretanto podem mostrar-se ineficientes aos agregados reciclados e porosos. Por esta razão, entende-se que todos os métodos oficiais de caracterização de agregados, que utilizem água, tendem a apresentar resultados incoerentes caso sejam utilizados agregados mais densos que a água, e com elevada taxa de absorção, como os reciclados. Entretanto, alguns pesquisadores como Vanderley Jonh, utilizam a taxa de absorção por regressão, obtida no instante de 5min após o agregado seco entrar em contato com a água, pois sua utilização no estado saturado com superfície seca pode impedir o intertravamento mecânico da pasta de cimento aos poros do agregado.

Como a absorção dos agregados é demorada, os mesmos autores propõem uma metodologia alternativa para a determinação da absorção. Com base na NBR 9937/87, os agregados reciclados, sustentados por um recipiente com malha de abertura de $0,075 \mathrm{~mm}$, são imersos em água, determinando a absorção ao longo do tempo. A Figura 2. 9 demonstra a curva de absorção do agregado reciclado em função da primeira leitura.

Esta elevada absorção de água, provocada pela utilização de saibro arenoso em substituição da cal, em algumas regiões do país, pode ser prejudicial pois, segundo CAVANI \& OLIVEIRA (2002), os teores excessivos de materiais finos 
exigem acréscimo na quantidade de água. Desta forma, surgirão maiores retrações por secagem que podem comprometer a estanqueidade e aderência de argamassas.

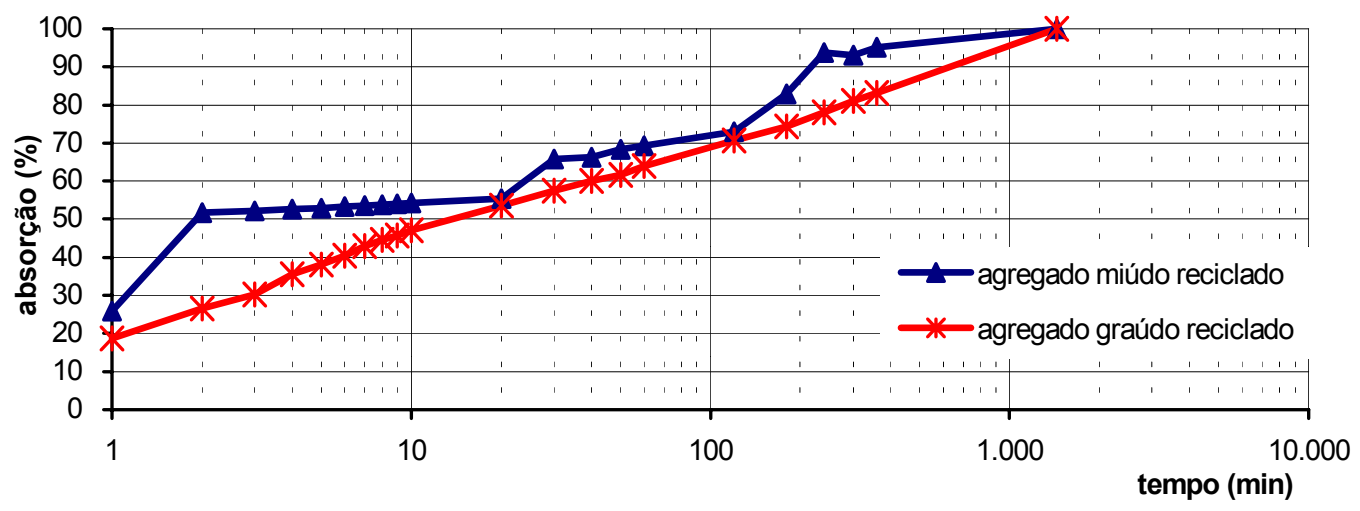

Figura 2.9 - Curva do percentual de absorção do agregado reciclado miúdo e graúdo, nas primeiras 24 horas

FONTE: LEITE et al., 2000

Além disto, ao adicionar mais água, este acréscimo provavelmente influenciará na resistência à compressão. Entretanto, o fluxo de água que migra ao interior do material pela alta porosidade, contribui para que haja melhor aderência entre pasta e agregado, pois a pasta de cimento pode ser absorvida pelos poros mais superficiais do agregado, contribuindo para o aumento da aderência.

Segundo AÏTCIN (2000), o agregado somente absorverá água da mistura, quando o teor de água do agregado estiver inferior ao estado saturado com superfície seca. No entanto, a água absorvida para dentro do agregado não contribui para o abatimento, nem para sua resistência, pois se adota a hipótese de que esta parcela não participe da hidratação do cimento. Entretanto, esta suposição não explica os aumentos de resistência obtidos por LATTERZA (1998), com valores superiores às resistências à compressão dos concretos de referência. Neste caso, a hipótese mencionada por AÏTCIN (2000), é válida quando se garante que o elemento seja curado por imersão de água, impedindo a retirada de água de hidratação do cimento por evaporação, e o surgimento de retração por secagem. Sendo assim, a melhor explicação dos resultados obtidos por LATTERZA (1998), é que a parcela de água absorvida não participa da hidratação inicial do cimento; porém, como está presente nos poros dos agregados reciclados, contribui ao longo do tempo, para o processo de hidratação, proporcionando a chamada "cura úmida interna". 
Para que as misturas no estado fresco, contendo agregados com elevada absorção de água, não sejam prejudicadas, AÏTCIN (2000) comenta que a saturação previa do agregado por mais de $24 \mathrm{hs}$, permite ao agregado leve saturar-se por inteiro, não afetando na trabalhabilidade e no abatimento. No entanto, a massa do concreto no estado fresco e endurecido, seria significativamente maior.

Ao analisar a pré-saturação dos agregados de RCD, ZORDAN et al. (1999) verificaram que o fluxo de água em direção ao interior dos grãos é inexistente, entretanto há aumento de porosidade na zona de transição pasta-agregado, por causa da quantidade de água livre disponível na interface, conforme Figura 2. 10. Segundo GONÇALVES (2001), apesar de ter uma espessura muito delgada ao redor do agregado, a zona de transição é geralmente mais fraca do que as outras duas fases.

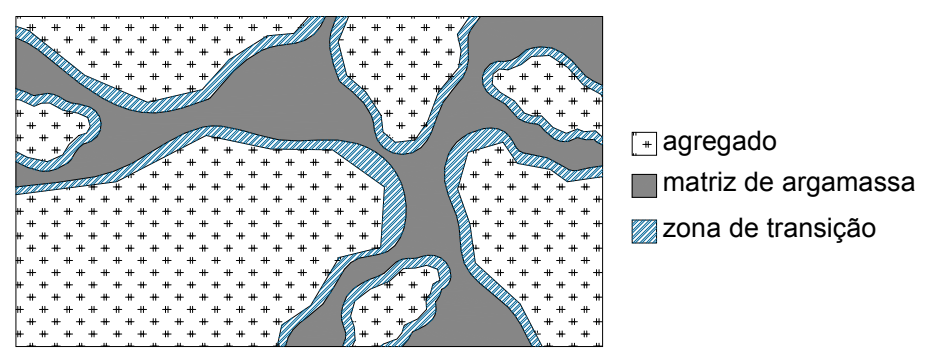

Figura 2.10 - Zonas de transição do concreto

FONTE: GONÇALVES, 2001

\subsubsection{Produtos de concreto com agregado reciclado}

\subsubsection{Blocos de concreto}

Ao estudar a substituição de agregados naturais por reciclados, na produção de blocos de vedação $(39 \times 19 \times 19) \mathrm{cm}$, com traço padrão de 1:8, DE PAUW ${ }^{9}$ apud ANGUlo (2000) verificou que os agregados de fração 3-12 mm apresentaram resistência média à compressão inferior à série com fração $0-2,5 \mathrm{~mm}$, conforme Tabela 2. 6 .

${ }^{9}$ DE PAuw, C. (1982). Recyclage des Descombres d'Une Ville Sinistree. C.S.T.C., revue n.4, p.12-28. dez., 1982. 
Tabela 2.6 - Estudo de dosagem para determinação do traço $e$ resistência à compressão média dos blocos

\begin{tabular}{|c|c|c|c|c|c|c|}
\hline \multirow{3}{*}{ série } & \multicolumn{5}{|c|}{ "dosagem (kg) } & \multirow{3}{*}{$\begin{array}{c}\text { resistência à } \\
\text { compressão } \\
(\mathrm{MPa})\end{array}$} \\
\hline & cimento & \multicolumn{2}{|c|}{ agregado natural } & \multicolumn{2}{|c|}{ agregado reciclado } & \\
\hline & P15-302 & $\# 0-2 \mathrm{~mm}$ & \#4-8mm & $\# 0-2,5 \mathrm{~mm}$ & $\# 3-12 \mathrm{~mm}$ & \\
\hline referência & 50 & 100 & 300 & - & - & 3,7 \\
\hline 1 & 50 & 150 & - & 250 & - & 2,2 \\
\hline 2 & 50 & 100 & - & 200 & - & 3,3 \\
\hline 3 & 50 & 200 & - & 200 & - & 2,9 \\
\hline 4 & 50 & 150 & - & - & 300 & 4,1 \\
\hline 5 & 50 & 150 & - & - & 250 & 7,0 \\
\hline 6 & 50 & 200 & - & - & 200 & 2,1 \\
\hline
\end{tabular}

FONTE: DE PAUW apud ANGUlo (2000)

Pimienta \& DelmotTe (1998) também produziram blocos vazados de concreto com agregados naturais e reciclados provenientes dos RCD. Com dimensão de $50 \times 20 \times 20 \mathrm{~cm}$ (comprimento, espessura, altura) e paredes de $100 \times 20 \times 100 \mathrm{~cm}$, os autores verificaram bom comportamento estrutural, conforme Tabela 2. 7.

Tabela 2.7 - Composição e resultados dos ensaios de blocos e paredes de alvenaria

\begin{tabular}{c|c|c}
\hline \hline traço e resultados & reciclado & natural \\
\hline \hline cimento CPA HP $(\mathrm{kg})$ & 1,00 & 1,00 \\
agregado natural de fração 0-6mm $(\mathrm{kg})$ & 8,65 & - \\
agregado reciclado de fração 6-12mm $(\mathrm{kg})$ & 3,78 & - \\
agregado natural de fração 0-12mm $(\mathrm{kg})$ & - & 14,08 \\
água (I) & 1,06 & 1,04 \\
\hline \hline massa específica do bloco $\left(\mathrm{kg} / \mathrm{dm}^{3}\right)$ & 2,05 & 2,15 \\
resistência média à compressão dos blocos $(\mathrm{MPa})$ & 5,93 & 5,31 \\
resistência à compressão das paredes $(\mathrm{MPa})$ & 3,80 & 4,00 \\
módulo de elasticidade das paredes (GPa) & 6,61 & 6,80 \\
\hline \hline
\end{tabular}

FONTE: Pimienta \& Delmotte, 1998

\subsubsection{Argamassas $\underline{\text { e concretos de agregado reciclado }}$}

Ao estudar a possibilidade de produzir argamassas contendo agregados naturais e reciclados em traços distintos de argamassas mistas de cimento e cal, em volume, HAMASSAKI et al. (1997) concluíram que as maiores retrações ocorrem com a presença e o acréscimo de cal, e com a presença de bloco cerâmico. Entretanto, é interessante ressaltar que argamassas produzidas com areia, apresentaram 100\% de acréscimo de retração dos 14 aos 84 dias de idades. 
Os traços de argamassas ausentes de agregado miúdo natural, e com baixo consumo de cal, possibilitaram as maiores resistências à compressão.

Outro fato relevante foi que a presença de bloco cerâmico às argamassas mistas de cimento, cal e agregado miúdo, aumenta a retenção de água no estado fresco e a retração por secagem aos 14 e 84 dias, porém não influencia na resistência à compressão.

Ao comparar a taxa de carbonatação em concretos confeccionados com agregados naturais e reciclados, BARRA \& VAZQUEZ (1997) verificaram que a possibilidade de ocorrer a carbonatação é maior para concretos executados com agregados reciclados, quando o consumo de cimento é superior a $400 \mathrm{~kg} / \mathrm{m}^{3}$. No entanto, para um consumo inferior a $300 \mathrm{~kg} / \mathrm{m}^{3}$, a taxa de carbonatação em concretos com agregados distintos não se altera. Em relação à permeabilidade da argamassa presente no concreto, concluíram que a argamassa nova é menos permeável que a argamassa velha fixada no agregado reciclado. Neste caso, o "foco de expansão" será o agregado reciclado, carbonatando primeiro ao redor da área da argamassa velha.

Além disto, os mesmos autores analisaram a profundidade de carbonatação em função da ordem de incorporação dos materiais, dividida em:

- agregado graúdo reciclado + água + cimento + areia;

- cimento + água + agregado graúdo reciclado + areia;

- cimento + água + areia + agregado graúdo reciclado.

Dentre estes, a série que possibilitou a menor profundidade de carbonatação foi a primeira. Como a absorção do agregado graúdo é elevada, ao adicionar a pasta de cimento, haverá grande quantidade deste que irá penetrar nos poros do agregado, até saturar. Desta forma, as interfaces da pasta-agregado serão melhoradas, pois se reduz o teor de água presente da argamassa ao redor do agregado, diminuindo conseqüentemente a dimensão dos poros da mesma, inibindo o "foco de expansão" da carbonatação. 


\subsection{Alvenaria}

A alvenaria foi um dos primeiros processos construtivos que o homem utilizou. Os blocos estruturais, constituídos por rochas, também tiveram importante destaque na história, e ainda hoje, promovem uma agradável estética, salientando-se o auto-relevo e as cores naturais variadas, que inspiram ainda hoje, vários arquitetos com características arrojadas.

É interessante lembrar que, em determinadas regiões litorâneas, durante a colonização brasileira, a escassez de argila e calcário para a confecção de uma argamassa, possibilitou o surgimento de paredes de alvenaria, assentadas com blocos rochosos sobre uma massa não convencional, mas com propriedades aglomerantes. Constituída basicamente por areia, conchas de crustáceos, gordura e óleo de baleia, e água salgada, este tipo de argamassa possibilitou a construção de "fortes" e igrejas, presentes em algumas cidades históricas, como Salvador e Porto Seguro.

\subsubsection{Princípios da alvenaria}

Devido à facilidade de execução de paredes utilizando elementos com dimensões padronizadas, a alvenaria estrutural proporciona velocidade à construção, além de economia oriunda do baixo consumo de cimento utilizado na argamassa de assentamento que é destinado à união dos elementos de alvenaria.

OLIVEIRA (2001) cita outras vantagens da utilização da alvenaria estrutural sob o aspecto econômico oferecido pelo processo de racionalização da estrutura, como a possibilidade da subdivisão de espaço, e ao utilizar outros produtos, internamente e externamente, possibilitam o isolamento térmico, proteção ao fogo e conforto às condições climáticas. Entretanto, possui algumas restrições ao ser solicitada por cisalhamento, tração e flexão.

Segundo Bortoluzzo (2000), os blocos são responsáveis pela resistência a esforços mecânicos, durabilidade a agentes agressivos, estabilidade e precisão dimensional. As variações dimensionais, provocadas pela expansão térmica 
e pela retração por secagem, levam à perda de aderência, surgindo fissuras na interface bloco-argamassa. Dentre as principais funções da argamassa de assentamento, a união das unidades de alvenaria para formar as paredes e elementos estruturais, e o impedimento da passagem de ar e da umidade, através das juntas, conferem às paredes, algumas propriedades como resistência mecânica, deformabilidade, estanqueidade, isolamento termo-acústico, segurança ao fogo, higiene e estética (BAYEUX, 2000).

A aderência da argamassa de assentamento é de total importância, pois é responsável pela capacidade da junta resistir a esforços de tração perpendiculares ao plano da junta e aos esforços de cisalhamento devido às forças tangenciais à junta, além de suportar acomodações internas de origem térmica. Esta aderência garantirá à edificação que responda a quaisquer solicitações oriundas de tensões de cisalhamento nas paredes, como as ocasionadas pelas forças laterais originadas pelo vento.

\subsubsection{Desempenho mecânico da alvenaria}

Com o passar dos tempos, as estruturas de alvenaria foram estudadas com comportamento empírico, passando à ensaios de paredes em escala real. No entanto, devido ao elevado custo e à demora de construção e execução do ensaio, estes tiveram de ser correlacionados em escalas cada vez menores, como os prismas e paredes de menores dimensões. Desta forma, estas correlações permitem ao projetista obter parâmetros para o dimensionamento utilizando análise numérica.

\subsubsection{Componentes de alvenaria}

Ao estudarem o comportamento estrutural dos blocos de concreto para alvenaria estrutural, CHEEMA \& KLINGNER $^{10}$ apud MOHAMAD (1998) propõe um

${ }^{10}$ CheEma \& Klingner (1986). Compressive Strength of Concrete Masonry Prisms - ACI Journal, jan/feb. 
modelo para determinar a resistência à tração dos blocos $\left(\mathrm{f}_{\mathrm{tb}}\right)$ de alvenaria, representada pela Equação 2. 3.

$$
\mathrm{f}_{\mathrm{tb}}=0,41 \cdot \sqrt{\mathrm{f}_{\mathrm{b}}}
$$

Onde:

$\mathrm{f}_{\mathrm{b}}$ : resistência à compressão do bloco $(\mathrm{MPa})$

MOHAMAD (1998) realizou ensaio de resistência à tração indireta conforme a Figura 2. 11, sendo que o diâmetro da barra de carregamento é de $3,1 \mathrm{~mm}$, com taxa de carregamento de $0,33 \mathrm{MPa} / \mathrm{min}$, e sendo a resistência determinada segundo a Equação 2. 4, proposta pela ASTM C1006-84 ${ }^{11}$.

$$
\mathrm{T}=\frac{2 \cdot \mathrm{P}}{\pi \cdot \mathrm{L} \cdot \mathrm{h}}
$$

Onde:

$\mathrm{T}$ : resistência à tração na seção transversal $(\mathrm{MPa})$;

$\mathrm{P}$ : carga aplicada à máquina $(\mathrm{N})$;

L: largura da amostra $(\mathrm{mm})$;

h: altura da amostra (mm).

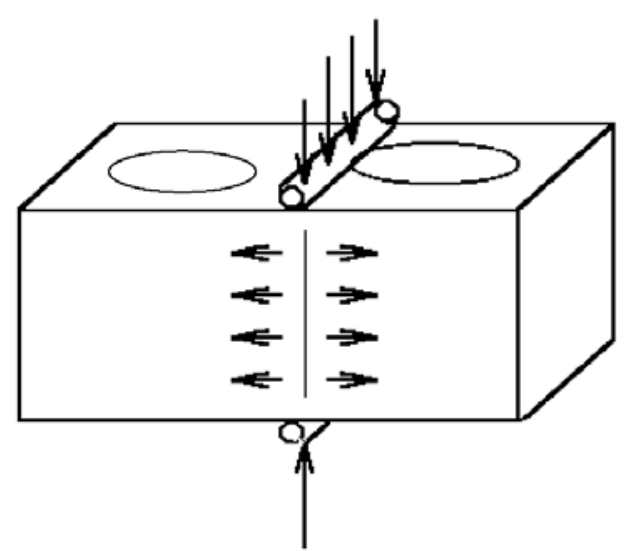

Figura 2.11 - Ensaio de resistência à tração indireta do bloco de alvenaria

FONTE: MOHAMAD, 1998

${ }^{11}$ ASTM C1006-84. Standart Test Method for Splitting Tensile Strenght of Masonry Units. 
HOLM $^{12}$ apud MEDEIROS (1993) verificou que o método de ensaio indireto de tração por cisalhamento resulta em maiores resistências quando comparadas ao método direto nomeado de "blockbuster" (Figura 2. 12). Nota-se que este método consiste em distribuir uniformemente as tensões ao espaço vazio do bloco, rompendo-o por tração direta utilizando duas cunhas, conforme Figura 2.13.

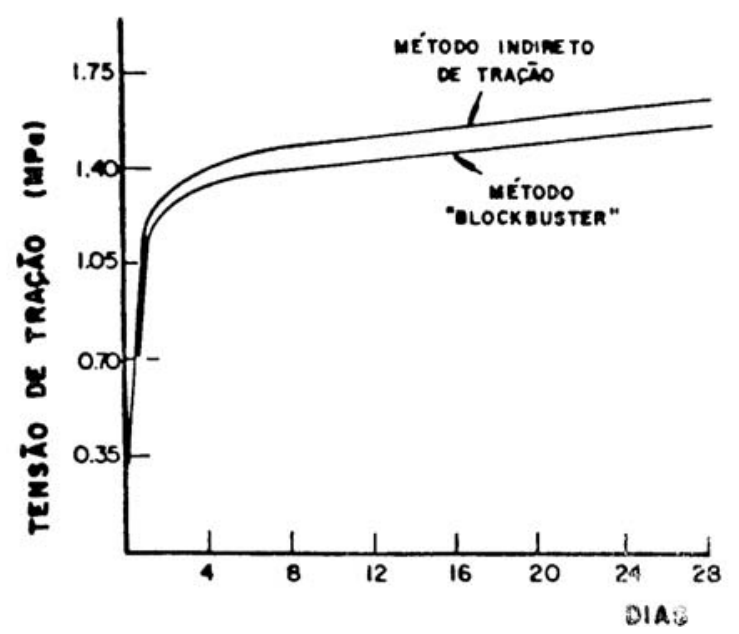

Figura 2.12-Resistência de tração pelo método indireto e "blockbuster"

FONTE: HOLM apud MEDEIROS (1993)
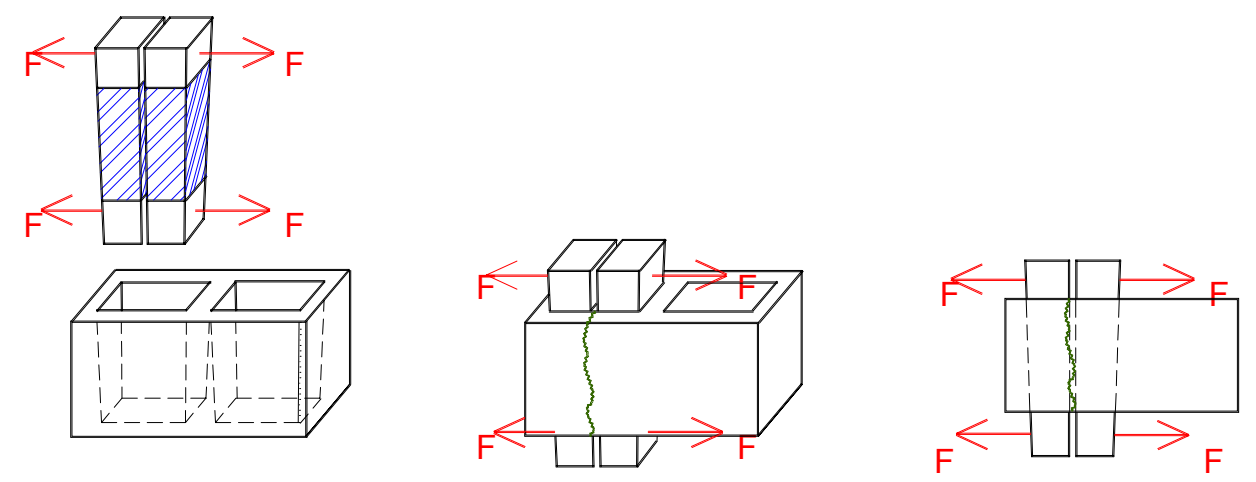

Figura 2.13 - Método direto de tração “blockbuster”

FONTE: MEDEIROS, 1993

Ao analisarem as argamassas de assentamento, CheEMA \& KLINGNER apud MOHAMAD (1998) concluíram que o módulo de elasticidade tangente da

12 Holm, T.A. (1976). Block concrete is a structural material. Journal of Testing and Evaluation, V.4, n.4, p.293-239, jul. 
argamassa $\left(E_{a t}\right)$ pode ser determinado em função da resistência à compressão da mesma, e que o módulo secante $\left(\mathrm{E}_{\mathrm{as}}\right)$ representa a metade do módulo tangente, conforme Equação 2. 5 e Equação 2. 6.

$$
\begin{aligned}
& \mathrm{E}_{\mathrm{at}}=1000 \cdot \mathrm{f}_{\mathrm{arg}} \\
& \mathrm{E}_{\mathrm{as}}=500 \cdot \mathrm{f}_{\mathrm{arg}}
\end{aligned}
$$

Onde:

$\mathrm{f}_{\text {arg }}$ : resistência à compressão da argamassa $(\mathrm{MPa})$

\subsubsection{Paredes de alvenaria}

A resistência das unidades de alvenaria é o principal fator que determina a resistência da parede de alvenaria. Entretanto, o aumento de resistência do bloco não é proporcional ao acréscimo da resistência do painel. A Figura 2.14 expõe as relações entre a resistências de cálculo da alvenaria e a resistência característica do bloco e do tipo de argamassa, possibilitando ao projetista estimar a solicitação a ser suportada pela parede de alvenaria. Ressalta-se que estas relações foram determinadas em painéis de $1,2 \mathrm{~m}$ a $1,8 \mathrm{~m}$ de largura com $2,4 \mathrm{~m}$ a $2,7 \mathrm{~m}$ de altura.

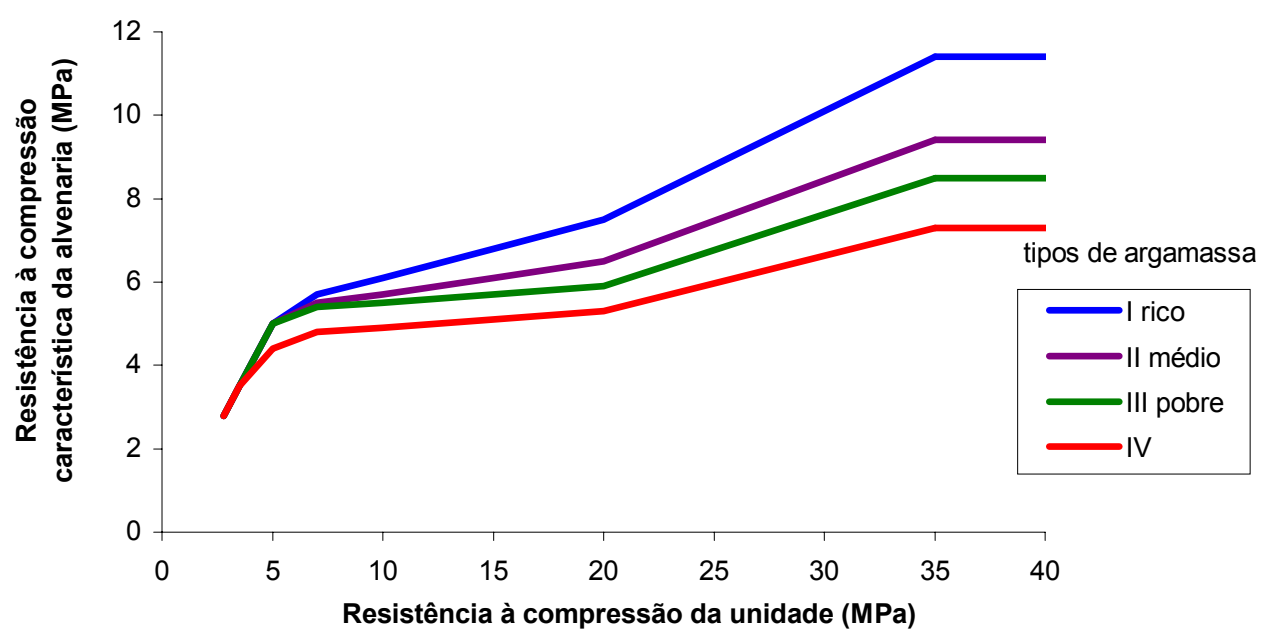

Figura 2.14 - Relação entre a resistência de cálculo da alvenaria e a resistência à compressão dos materiais constituintes

FONTE: $\quad$ BS 5628 part 1, 1978

Os tipos de argamassas mistas com cimento, cal e agregado miúdo, da figura acima, variam em função do consumo de cimento, mantendo a relação aglomerantes/agregado igual a 1:3. A Tabela 2. 8 apresenta as resistências à 
compressão de ensaios moldados em laboratório e "in loco" pela a BS 5628 part 1 (1978), aos 28 dias de idade.

Tabela 2.8 - Requisitos da argamassa

\begin{tabular}{|c|c|c|c|c|c|}
\hline \multirow{2}{*}{ tipo } & \multicolumn{3}{|c|}{ proporção (L) } & \multicolumn{2}{|c|}{ resistência aos 28 dias (MPa) } \\
\hline & P1 & P2 & P3 & laboratório & "in loco" \\
\hline I rico & $1: 0-0,25: 3$ & - & - & 16,0 & 111,0 \\
\hline II médio & $1: 0,5: 4-4,5$ & $1: 2,5-3,5$ & $1: 3-4$ & 6,5 & 4,5 \\
\hline III pobre & $1: 1: 5-6$ & $1: 4-5$ & $1: 5-6$ & 3,6 & 2,5 \\
\hline IV & $1: 2: 8-9$ & $1: 5,5-6,5$ & $1: 7-8$ & 1,5 & 1,0 \\
\hline
\end{tabular}

P1: cimento : cal : areia P2: cimento de alvenaria : areia P3: cimento: areia com plastificante FONTE: $\quad$ BS 5628 part 1, 1978

O EuROCóDIGO 6 (1996) possibilita determinar a resistência característica à compressão da alvenaria $\left(f_{k}\right)$, não apenas em função do elemento estrutural, mas também da influência da resistência da argamassa (Equação 2. 7).

$$
\mathrm{f}_{\mathrm{k}}=\mathrm{k} \cdot \mathrm{f}_{\mathrm{b}}{ }^{0,65} \cdot \mathrm{f}_{\mathrm{a}}^{0,25}
$$

Onde:

$\mathrm{f}_{\mathrm{a}}$ : resistência média à compressão da argamassa $(\mathrm{MPa})$;

$\mathrm{f}_{\mathrm{b}}$ : resistência média à compressão do elemento estrutural (MPa);

$\mathrm{k}$ : varia de 0,4 e 0,6 , dependendo do assentamento do bloco e da argamassa.

A revista PRISMA ${ }^{13}$ cita que é comum relacionar as resistências à compressão dos blocos e prismas. Devido à influência da esbeltez dos prismas, da resistência da argamassa e da espessura da junta de argamassa de assentamento, a resistência dos prismas varia de $70 \%$ a $90 \%$ da resistência característica dos blocos de concreto.

No entanto, o desempenho da parede de alvenaria não depende apenas de sua resistência mecânica. Outra propriedade no estado endurecido, como elasticidade do elemento, possibilita prever as deformações em regime elástico, através do "módulo de elasticidade longitudinal" (deformação). Definido pela tensão necessária para provocar uma deformação unitária, pode ser determinado por uma reta que

\footnotetext{
${ }^{13}$ PriSMA, São Paulo, nº2, p.31, março, 2002
} 
passa pela origem da curva tensão-deformação do elemento, sob carregamento uniaxial, à determinada declividade. A correlação gráfica entre a resistência mecânica e o módulo de deformação é usual, pois a massa específica do aglomerante é inversamente proporcional à porosidade, a qual influencia na resistência do material.

Segundo Bortoluzzo (2000), os módulos de elasticidade nos materiais heterogêneos, como concretos e argamassas, são afetados pelos seguintes fatores:

a ) agregados, pois limitam a deformação da argamassa;

b ) matriz de pasta aglomerante, na qual a relação água/cimento definirá a porosidade da matriz;

c ) parâmetros de ensaio, cujo aumento da velocidade de aplicação do carregamento implica no aparecimento de fissuras e no grau de não linearidade na curva tensãodeformação, aumentando o módulo de deformação;

d ) corpos-de-prova úmidos, aumentam em 15\% o módulo de deformação.

Segundo VASCONCELOS \& GiAMMUSSO (1998), o módulo de deformação é importante não apenas para se verificar o deslocamento que o material sofreu sob determinado carregamento, mas também para analisar a deformação microscópica do material. Como pode ser visto na Figura 2. 15, as microfissuras somente aparecem na zona de transição dos agregados e da pasta de cimento, sobre carregamento superior a $30 \%$ da tensão última. $\mathrm{Na}$ faixa de $50 \%$ a $75 \%$ da tensão última, o comportamento do material não possui mais linearidade e, ao superar $75 \%$, os agregados perdem a aderência com a pasta de cimento, com tendência das microfissuras unirem-se umas às outras, tornando o sólido instável e sujeito à ruptura. 

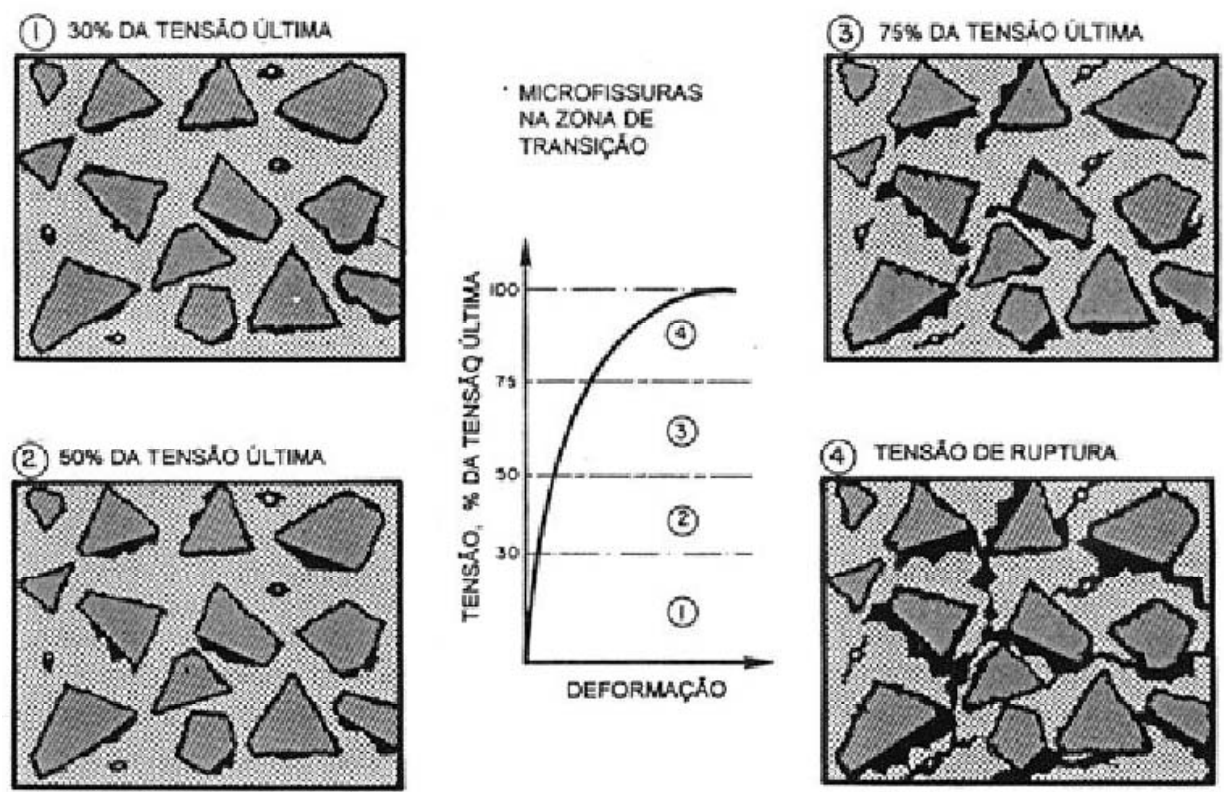

Figura 2.15 - Representação esquemática do comportamento tensãodeformação do concreto sob compressão simples

FONTE: VASCONCELOS \& Giammusso, 1998

Ao estudar a influência da rigidez dos componentes da alvenaria, CHEEMA \& KLINGNER apud MOHAMAD (1998) consideram os seguintes mecanismos de ruptura de blocos de concreto em prismas não grauteados:

a ) Tração no bloco, sendo a tensão principal ser maior que a resistência à tração;

b ) Esmagamento do bloco, sendo a tensão principal de compressão no bloco ser maior que a resistência à compressão da argamassa;

c ) Esmagamento da argamassa, oriunda da tensão de compressão axial no bloco ser maior que a resistência da argamassa confinada.

Desta forma, os autores propuseram um modelo, que estima a forma de ruptura de prismas de alvenaria, baseado na relação entre os módulos de elasticidade da argamassa $\left(E_{\text {arg }}\right)$ utilizada no assentamento e do bloco de alvenaria $\left(E_{b}\right)$, conforme Equação 2.8 e Equação 2. 9.

$$
\begin{aligned}
& E_{a r g} / E_{b} \geq 0,66 \Rightarrow \text { ruptura por esmagamento da argamassa } \\
& E_{a r g} / E_{b}<0,66 \Rightarrow \text { ruptura por tração no bloco }
\end{aligned}
$$


Nas rupturas caracterizadas pelo esmagamento da argamassa, determinou-se a equação da curva que relaciona as deformações dos componentes da parede de alvenaria com as resistências à compressão dos prismas $\left(f_{p}\right)$ e argamassas $\left(f_{a}\right)$, conforme mostra a Figura 2. 16.

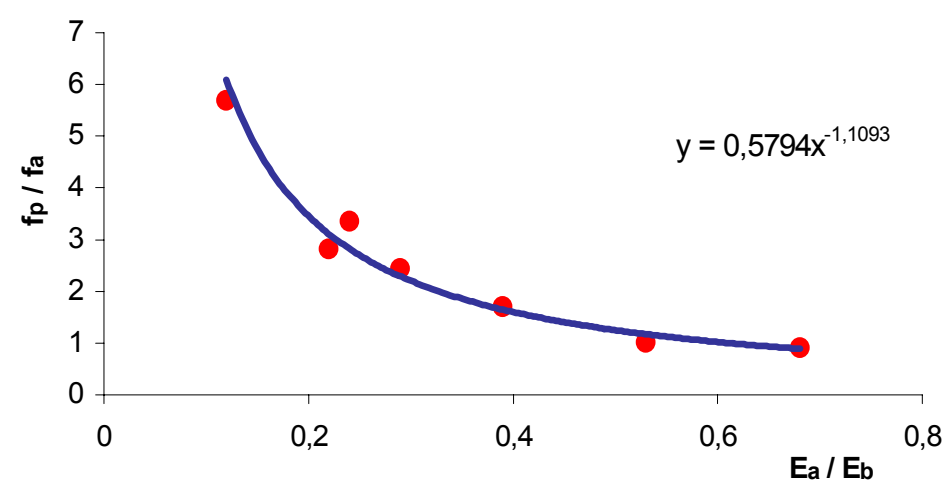

Figura 2.16 - Relação entre $E_{a} / E_{b}$ e $f_{p} / f_{a}$ FONTE: MOHAMAD, 1998

Da mesma forma, determinou-se a equação que representasse a curva da relação entre os módulos de elasticidade dos componentes da alvenaria com a resistência à compressão do prisma e à tração do bloco $\left(f_{\mathrm{bt}}\right)$, conforme Figura 2. 17.

Com as Equações 2. 10 e 2. 11, CHEEMA \& KLINGNER determinaram a estimativa da resistência última do prisma que resultou em valores muito próximos, tanto experimental quanto na comparação com outros pesquisadores, quando a ruptura ocorre na argamassa ou por tração no bloco, respectivamente.

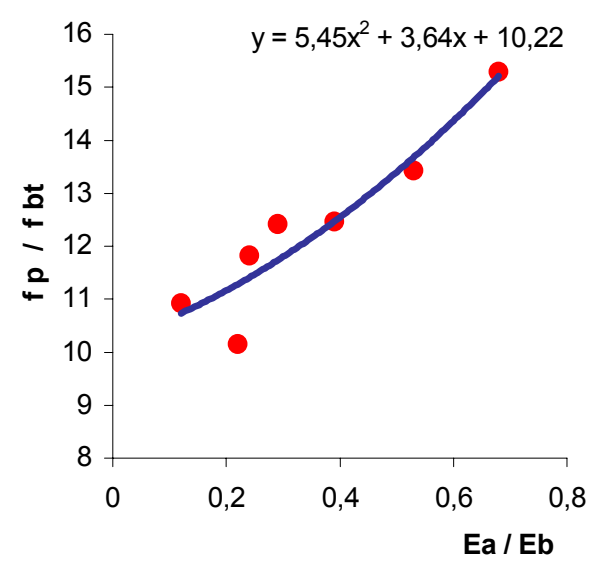

Figura 2.17 - Relação entre $E_{a} / E_{b} e f_{p} / f_{b t}$

FONTE: MOHAMAD, 1998 


$$
\begin{aligned}
& \mathrm{f}_{\mathrm{p}}=\mathrm{f}_{\mathrm{a}} \cdot 0,5794 \cdot\left(\mathrm{E}_{\mathrm{a}} / \mathrm{E}_{\mathrm{b}}\right)^{-1,1093} \\
& \mathrm{f}_{\mathrm{p}}=\mathrm{f}_{\mathrm{bt}} \cdot\left[5,45 \cdot\left(\mathrm{E}_{\mathrm{a} / \mathrm{E}_{\mathrm{b}}}\right)^{2}+3,64 \cdot\left(\mathrm{E}_{\mathrm{a}} / \mathrm{E}_{\mathrm{b}}\right)+10,22\right]
\end{aligned}
$$

No entanto, não há um método universalmente aceito para a determinação do módulo de deformação longitudinal dos blocos de alvenaria, cujo valor depende da tensão máxima atingida durante o ensaio. Usualmente, utiliza-se uma reta secante entre a origem e o valor correspondente a $40 \%$ da tensão máxima da curva tensão-deformação. Para os concretos, de uma forma geral, a norma NBR8522/84 determina o plano de carregamento a ser efetuado para a avaliação do módulo de deformação. O cálculo do módulo de deformação secante é determinado pela Equação 2. 12 a partir do diagrama tensão-deformação, pela inclinação da reta secante que corta o diagrama nos pontos correspondentes à tensão de $0,5 \mathrm{MPa}$ e à tensão " $n$ " considerada para o cálculo do módulo secante.

$$
E_{\mathrm{sec}, n}=\frac{f_{c, n}-f_{c, 0.5}}{\varepsilon_{n}-\varepsilon_{0.5}}
$$

Onde:

$\mathrm{E}_{\mathrm{sec}, \mathrm{n}}$ é o módulo de deformação secante;

$\mathrm{f}_{\mathrm{c}, \mathrm{n}}$ é a tensão considerada para o cálculo do módulo secante no ponto $\mathrm{n}$;

$\varepsilon_{\mathrm{n}}$ é a deformação específica correspondente a tensão $\mathrm{f}_{\mathrm{c}, \mathrm{n}}$;

$\varepsilon_{0,5}$ é a deformação específica correspondente a tensão $0,5 \mathrm{MPa}$.

Porém, como os blocos de concreto possuem resistências à compressão relativamente baixas quando comparados aos concretos de consistência plástica, devido à falta da matriz aglomerante, este método torna-se inviável devido ao fato da tensão de $0,5 \mathrm{MPa}$ e da respectiva deformação, representarem valores muitas vezes superiores a $10 \%$ da tensão máxima. Ao adotar um valor próximo da origem, pode haver alguma incoerência devido à tensão de escorvação aplicada aos blocos de concretos, pois o elevado índice de vazios permite a desestruturação dos agregados. Além disso, fica muito abrangente a escolha da tensão a ser considerada pelo ponto “ $n$ ” proposto pela norma, podendo ser de $10 \%$ a $80 \%$ da tensão máxima. 
Para facilitar a determinação da secante, a ACI 530-92 estabeleceu que a tensão considerada " $n$ " não ultrapasse $30 \%$ da tensão máxima. Para facilitar a determinação do módulo de deformação da alvenaria, efetua-se uma reta secante nos primeiros estágios de carregamento, correspondente a 5\% e 33\% (Equação 2. 13). Esta proposta possibilita obter um valor confiável, desconsiderando descontinuidades na curva tensão-deformação e o efeito de acomodação do elemento estrutural ao capeamento, que podem alterar e ocultar o valor real.

$$
E_{\mathrm{sec}}=\frac{0,33 \cdot f_{c}-0,05 \cdot f_{c}}{\varepsilon_{0,33}-\varepsilon_{0,05}}
$$

Onde:

$E_{\text {sec }}$ é o módulo de deformação secante;

$\mathrm{f}_{\mathrm{c}}$ é a tensão máxima obtida na curva tensão-deformação;

$\varepsilon_{0,33}$ é a deformação específica correspondente a $33 \%$ da tensão máxima;

$\varepsilon_{0,5}$ é a deformação específica correspondente $5 \%$ da tensão máxima.

É comum relacionar o módulo de deformação da alvenaria com os valores da resistência última à compressão das paredes, possibilitando ao projetista de estruturas de alvenaria, estimar o módulo de deformação de paredes. A BS 5628part 2 (1992) possibilita estimar, empiricamente, o módulo de deformação da parede de alvenaria $\left(\mathrm{E}_{\mathrm{alv}}\right)$ em função da tensão máxima à compressão do painel de alvenaria $\left(f_{\text {alv }}\right)$ de blocos cerâmicos, sílico-calcáreos e de concretos, com ou sem graute, conforme a Equação 2. 14.

$$
\mathrm{E}_{\mathrm{alv}}=900 \cdot \mathrm{f}_{\mathrm{alv}}
$$

Porém, o EuRoCódigo 6 (1996) possibilita determinar o módulo de deformação da alvenaria a partir de um coeficiente multiplicado à tensão última da alvenaria, pelo modelo expresso pela Equação 2. 15.

$$
\mathrm{E}_{\mathrm{alv}}=1000 \cdot \mathrm{f}_{\mathrm{alv}}
$$

Entretanto, vários outros estudos demonstram que os módulos de elasticidade são muito divergentes, pois os resultados experimentais variaram de 700. $f_{\text {alv }}$ a $1000 . f_{\text {alv }}$. 


\subsubsection{Mecanismo de ruptura}

A alvenaria é constituída por materiais com diferentes características mecânicas, sendo que a resistência à compressão uniaxial e o módulo de deformação da argamassa são geralmente menores que os do bloco. Porém, a aderência e o atrito entre o bloco e a argamassa, impedem a deformação lateral da argamassa, criando um estado de tensão de compressão tri-axial na argamassa e tração axial lateral nos septos longitudinais dos blocos. Ao reagirem, as tensões laterais superam a resistência de tração do bloco, provocando a ruína por desenvolvimento de fissuras paralelas ao eixo de carregamento. Com isso, a alvenaria pode ser submetida a esforços maiores que os suportados pela argamassa no estado uniaxial.

Segundo OliveIRA (2001), o ensaio de compressão axial é sensível à excentricidade quando se aproxima da carga crítica da parede. Mesmo que haja controle da verticalidade do eixo da peça, pequenos desvios podem provocar uma excentricidade acidental, transformando o ensaio de compressão centrada em flexocompressão.

Ao verificar os tipos de ruptura em prismas, MOHAMAD (1998) concluiu que a fissuração do bloco varia em sua rigidez, pois quanto menor for o módulo de deformação, maior é a capacidade de deformar-se na lateral. Dependendo do módulo de deformação da argamassa utilizada no assentamento, podem surgir tensões de tração significativas no bloco, que resultam no esfacelamento dos septos longitudinais às juntas e estendem-se por todo o bloco. Como a rigidez da argamassa é diretamente proporcional ao consumo de cimento, apresenta-se na Figura 2. 18, os dois tipos de fissuras que podem ocorrer no bloco. O mesmo autor verificou que, para qualquer argamassa utilizada, os blocos de concreto apresentam deformações com comportamentos lineares a carregamentos inferiores a $50 \%$ da resistência última à compressão dos prismas. 


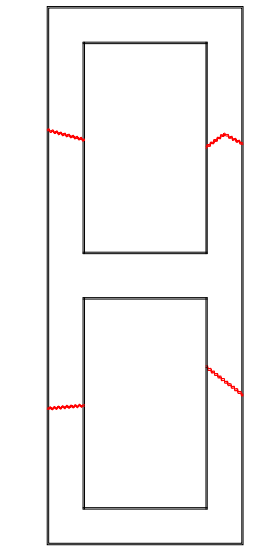

traço $1: 0,25: 3$

$1: 0,5: 4,5$

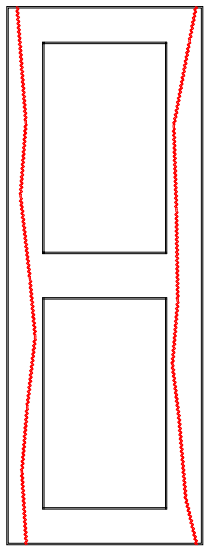

traço $1: 1: 6$

$1: 2: 9$

Figura 2.18 - Tipo de ruptura do bloco ocorrido nos prismas em função da argamassa

FONTE: MOHAMAD, 1998

Desta forma, o mesmo autor sugere que a resistência da argamassa varie de $70 \%$ a $100 \%$ da resistência à compressão do bloco na área bruta, para haver a compatibilidade entre argamassa e o tipo de bloco, otimizando desta forma, a resistência de cada componente.

\subsubsection{Qualidade}

Atualmente a falta de qualidade dos produtos à base de cimento, encontrados em muitas fábricas de blocos de concreto, desencoraja o mercado em relação ao processo construtivo de alvenaria estrutural. Este empecilho induziu à Associação Brasileira de Cimento Portland a lançar em 2001, o programa "Selo de Qualidade ABCP”. Segundo GROSSI (2001), o programa foi criado com o intuito de contribuir para a imagem positiva do sistema construtivo e desestimular, no mercado, a presença de produtos sem qualidade, além de certificar a conformidade dos produtos com as normas brasileiras. No entanto, o programa não discrimina as fábricas cujo produto esteja irregular, mas ajudará a empresa a obter e padronizar uma qualidade mínima aceitável para venda dos blocos de concreto. 


\subsubsection{Estudo de paredes de alvenaria}

\subsubsection{Eficiência de blocos, prismas $\underline{\text { e paredes }}$}

Ao se analisar o comportamento de paredes de alvenaria em paredes, produzidas com blocos vazados de concreto de meio bloco e inteiros, variando a argamassa de assentamento e a resistência característica dos blocos, MEDEIROS (1993) obteve os seguintes resultados dos ensaios de compressão e módulos de elasticidade dos blocos com seus respectivos fatores de eficiência (FE), conforme Tabela 2.9.

Tabela 2.9 - Comportamentos mecânicos e fatores de eficiência

\begin{tabular}{|c|c|c|c|c|}
\hline \multirow{2}{*}{ traço da argamassa } & \multirow{2}{*}{ Ensaio } & \multicolumn{3}{|c|}{ resistência do bloco (MPa) } \\
\hline & & 8,4 & 10,8 & 14,9 \\
\hline \multirow{3}{*}{$1: 1: 6$} & Resistência da parede (MPa) & $\begin{array}{l}4,28 \\
\end{array}$ & $4,8,83$ & $4,4,97$ \\
\hline & FE Parede/bloco & 0,51 & 0,45 & 0,33 \\
\hline & Módulo de deformação (MPa) & 3.900 & 4.200 & 5.500 \\
\hline \multirow{3}{*}{$4,55 \mathrm{MPa}$} & FE E/Parede & 911 & 870 & 1107 \\
\hline & Resistência da paredinha (MPa) & 4,63 & 5,11 & 6,07 \\
\hline & $\mathrm{FE}$ paredinha/Parede & 1,08 & 1,06 & 1,22 \\
\hline \multirow{3}{*}{$1: 0,5: 4$} & Resistência da parede (MPa) & 4,64 & 5,26 & 6,52 \\
\hline & FE Parede/Bloco & 0,55 & 0,51 & 0,44 \\
\hline & Módulo de deformação (MPa) & 4.300 & 5.100 & 7.300 \\
\hline \multirow{3}{*}{$5,89 \mathrm{MPa}(1,30)$} & $F E_{E / P a r e d e}$ & 926 & 970 & 1119 \\
\hline & Resistência da paredinha (MPa) & 4,75 & 5,41 & 5,90 \\
\hline & $\mathrm{FE}$ paredinha/Parede & 1,02 & 1,03 & 0,90 \\
\hline
\end{tabular}

FONTE: MEDEIROS, 1993

Nos blocos de menor resistência característica à compressão $(8,4 \mathrm{MPa}), \mathrm{o}$ incremento de resistência da argamassa de $130 \%$ correspondeu um aumento da resistência da parede de apenas $8 \%$. Para blocos de maior resistência $(14,9 \mathrm{MPa})$, o mesmo correspondeu a um acréscimo de $31 \%$ na resistência da parede.

\subsubsection{Paredes $\underline{\text { e prismas revestidos }} \underline{\text { com argamassa simples }}$}

Ao analisarem as resistências à compressão e módulos de elasticidade em paredes e prismas de 3 blocos com resistência característica de 1,84MPa, com e sem revestimento de argamassa mista de cimento, cal e areia, de traço igual a 1:2:11, em 
volume, CAVALHEIRO \& MULLER (1991) verificaram a influência do revestimento sobre a parede de alvenaria e da esbeltez da mesma, conforme Tabela 2. 10. A explicação do aumento de rigidez e da resistência é pelo fato de funcionar como elemento solicitado apenas por esforços cisalhantes, originados na interface com a alvenaria. Estes esforços, inferiores à resistência de aderência, podem ter inibido as deformações apenas do núcleo da alvenaria, aumentando seu módulo de deformação. A ruptura de paredes de alvenaria geralmente ocorre pela diferença dos módulos de elasticidade do bloco e da argamassa de assentamento, pois devido à maior capacidade de deformar-se, a argamassa provoca tensões de tração indireta ao bloco, ocasionando fissuras verticais nos septos. Além disto, a espessura do revestimento influencia apenas na capacidade de deformação e não na absorção dos esforços de compressão transferidos à alvenaria. No entanto, este ganho é obtido apenas em laboratório, pois em obra, apenas uma parcela do carregamento é transmitida à parede após o revestimento.

Tabela 2.10 - Influência do revestimento na resistência à compressão

\begin{tabular}{|c|c|c|c|c|c|c|c|}
\hline assentamento & tipo & $\overline{\mathrm{f}_{\mathrm{ppa}}(\mathrm{MPa})}$ & $\mathrm{E}_{\mathrm{ppa}}(\mathrm{MPa})$ & $\mathrm{f}_{\mathrm{ppa}} / \mathrm{f}_{\mathrm{bk}}$ & $f_{p p a} / f_{p b}$ & 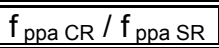 & $\mathrm{E}_{\mathrm{ppa} \mathrm{CR}} / \mathrm{E}_{\mathrm{ppa} \mathrm{SR}}$ \\
\hline \multirow{2}{*}{ menor face } & SR & 1,38 & 546 & 0,75 & 0,90 & \multirow{2}{*}{1,22} & \multirow{2}{*}{1,70} \\
\hline & CR & 1,68 & 927 & 0,92 & 1,10 & & \\
\hline \multirow{2}{*}{ maior face } & SR & 1,11 & 568 & 0,44 & 0,67 & \multirow{2}{*}{1,24} & \multirow{2}{*}{1,32} \\
\hline & CR & 1,38 & 749 & 0,55 & 0,84 & & \\
\hline
\end{tabular}

Bloco: $20 \times 14 \times 10 \mathrm{~cm}$ (comprimento, altura, largura)

Prismas assentados na maior face: $20 \times 43 \times 10$ Paredes assentadas na maior face: $42 \times 74 \times 13$

Prismas assentadas na menor face: $20 \times 33 \times 14$ Paredes assentadas na menor face: $42 \times 77 \times 17$

Fonte: CAVAlheiro \& Muller, 1991

\subsubsection{Influência do assentamento de prismas com argamassas distintas}

Em relação ao consumo de cimento na argamassa de assentamento, MOHAMAD (1998) concluiu que este influencia na relação de eficiência entre a resistência do prisma e a do bloco. A Figura 2. 19 mostra a queda na resistência à compressão e do módulo de deformação do prisma pelo aumento na resistência do bloco de 10,5MPa para diferentes argamassas mistas de cimento, cal e areia. 


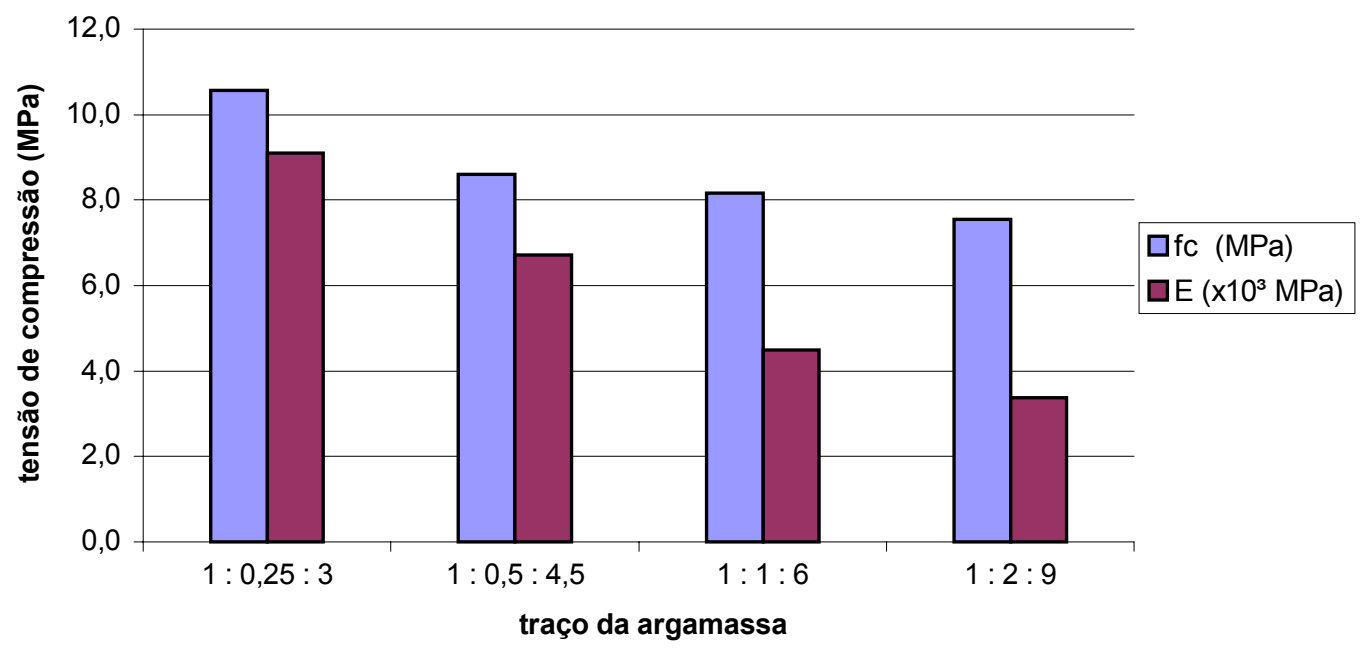

Figura 2.19 - Resistência à compressão e módulo de deformação dos prismas para argamassas com diferentes consumos de cimento

FONTE: MOHAMAD, 1998

\subsubsection{Revestimento de paredes de alvenaria com argamassas distintas}

Ao estudar o comportamento de paredes revestidas de argamassas contendo fibras e telas soldadas, destinadas à recuperação de paredes de alvenaria, OLIVEIRA (2001) concluiu que os corpos-de-prova de argamassa fraca, atingem seu limite de resistência muito antes da resistência última do conjunto bloco-argamassa de assentamento, promovendo uma ductilidade suficiente para continuar resistindo até a ruína do núcleo, conforme Figura 2. 20. Verificando o comportamento da aderência do revestimento, acredita-se que o descolamento desta está ligado a problemas de instabilidade interna dos componentes e materiais envolvidos. Ao aproximar-se da ruína, os componentes e os materiais passam a sofrer deslocamentos relativos internos, apresentando fissuras ou trincas, perdendo sua estabilidade dimensional e conseqüentemente sua capacidade resistente, podendo desagregar-se um do outro. 


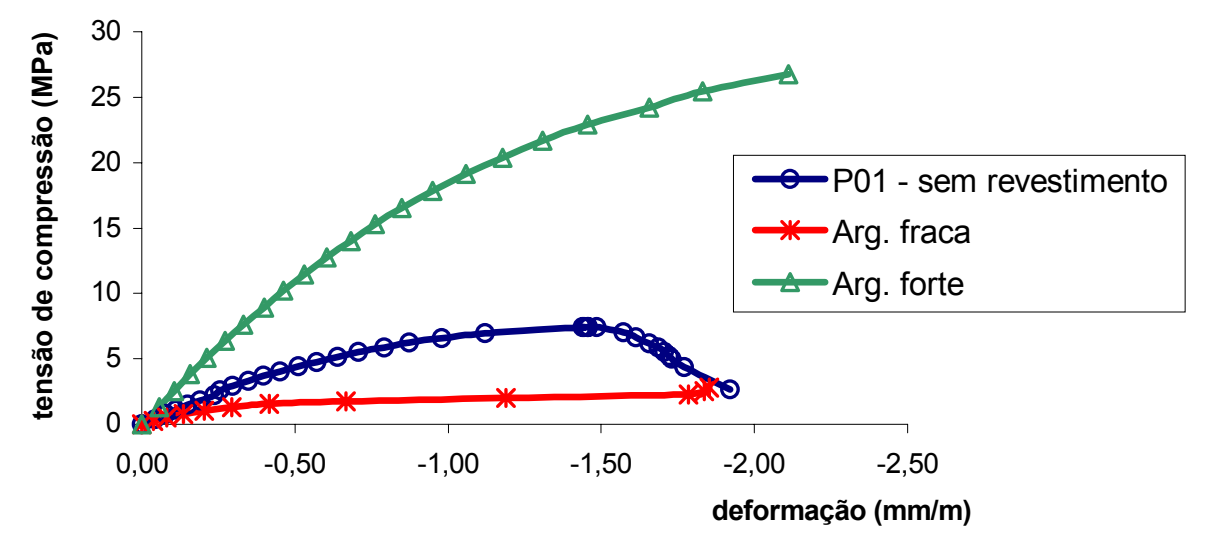

Figura 2.20 - Curva tensão-deformação da parede sem revestimento e das argamassas simples do revestimento

FONTE: OLIVEIRA, 2001

\subsubsection{Juntas verticais de paredes de alvenaria não preenchidas}

Conforme mencionado anteriormente, muitos edifícios foram construídos sem o preenchimento das juntas verticais. Segundo CAVALHEIRO et al. (2000), esta prática influencia tanto na alvenaria de vedação referente à performance acústica e na estanqueidade à água, quanto na alvenaria estrutural devido à redução do módulo de deformação da alvenaria. As forças laterais atuantes no plano da parede ou perpendicularmente a este, podem originar importantes tensões de cisalhamento e de tração na flexão, resultando em sérios danos, como surgimento de fissuras, flambagem e colapso das estruturas. A Tabela 2. 11 apresenta as tensões médias de cisalhamento resultantes do ensaio de compressão diagonal. Nota-se que argamassas mais fortes são mais influenciadas pelas juntas verticais.

Tabela 2.11 - Tensão média de cisalhamento nas paredes com blocos de concreto

\begin{tabular}{c|c||c|c}
\hline \hline tipo & argamassa & tensão de cisalhamento (MPa) & coef. de variação (\%) \\
\hline \hline \multirow{2}{*}{ junta } & $1: 1: 6$ & 0,43 & 2,8 \\
preenchida & $1: 0,5: 4,5$ & 1,03 & 24,7 \\
& $1: 0,25: 3,75$ & $>1,53$ & - \\
\hline \multirow{2}{*}{ junta não } & $1: 1: 6$ & $0,21(0,49)$ & 6,6 \\
preenchida & $1: 0,5: 4,5$ & $0,44(0,43)$ & 19,2 \\
& $1: 0,25: 3,75$ & $0,49(0,32)$ & 19,2 \\
\hline \hline
\end{tabular}

FONTE: CAVALHEIRO, 2000 
O mesmo autor verificou que a presença de revestimentos com elevado consumo de cimento modifica a orientação da fissuração dentada em paredes sem revestimento, por fissuras diagonais aos blocos do concreto. Em relação à permeabilidade das paredes, a presença do preenchimento das juntas resultou no aumento de volume de água acumulado na parede, conforme Figura 2. 21.

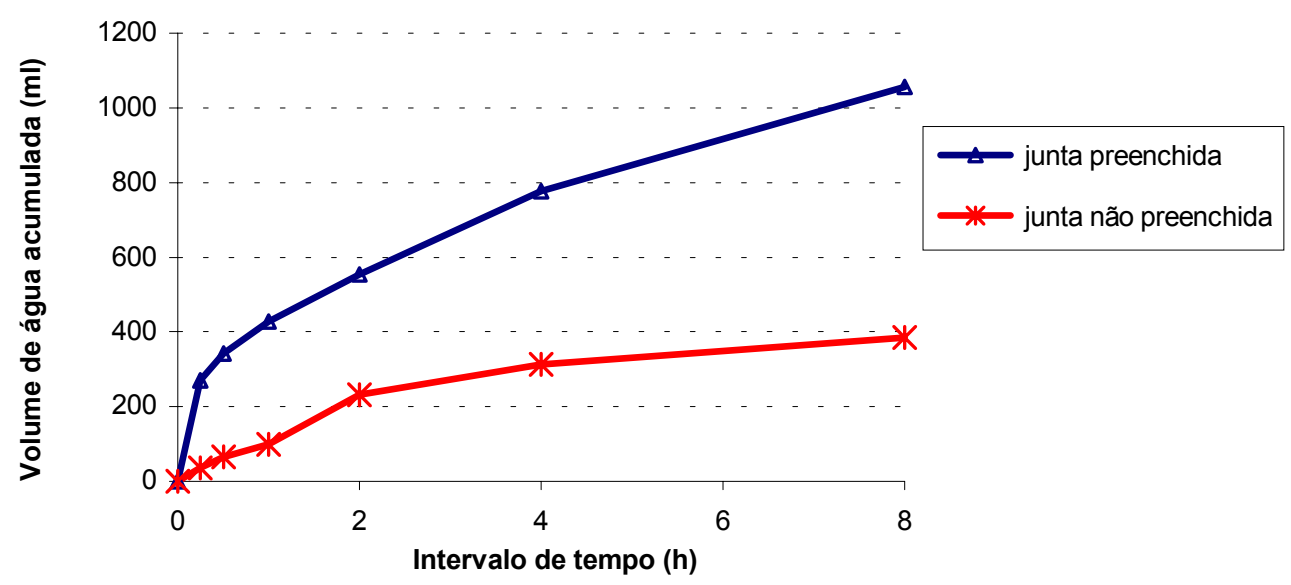

Figura 2.21 - Permeabilidade em paredes com revestimento em uma face variando o preenchimento da junta vertical de argamassa

FONTE: CAVALHEIRO, 2000

\subsection{Concreto com abatimento $\underline{\text { nulo }}$}

A tecnologia de concreto com abatimento nulo geralmente é utilizada na fabricação de estruturas pré-moldadas de concreto, como blocos de alvenaria. Segundo ABreu (2000), a Associação Brasileira de Cimento Portland define prémoldados de concreto como "peças de pequeno, médio ou grande porte, moldados com concreto ou argamassa de cimento Portland, com ou sem armadura, com ou sem responsabilidade estrutural. São geralmente produzidos em fábrica de artefatos de concreto, fora do local de utilização definitiva, por processo mecanizado e em escala industrial". 
As estruturas pré-moldadas de extrema qualidade são produzidas com concreto de alto desempenho, os quais são caracterizados por diversas propriedades no estado fresco e endurecido, como auto-adensado, abatimento nulo, com ar incorporado, alta e baixa densidade, alta resistência e reforçado com fibras. Adições, aditivos e modificações na energia de compactação são essenciais para obter estas propriedades.

Os elementos caracterizados com abatimento nulo apresentam consumo de cimento entre $100 \mathrm{~kg} / \mathrm{m}^{3}$ e $150 \mathrm{~kg} / \mathrm{m}^{3}$, pois, ao manter a consistência seca no estado fresco, a proporção de cimento em relação à quantidade de água utilizada também deve ser mantida.

A tecnologia do concreto com abatimento nulo não é limitada apenas à diminuição da quantidade de água, mas em estudos e cuidados referentes ao adensamento, cura e composição granulométrica. Dentre as varias técnicas, encontrase a energia de vibração aplicada, como sendo a de menor conhecimento. Segundo estudo realizado por DiAZ (1998), a freqüência de vibração e o método de como ela é aplicada, são os principais meios de obter uma estrutura de qualidade.

\subsubsection{Aplicação}

Além dos blocos de concreto para alvenaria, ABREU (2000) menciona outros artefatos pré-moldados de cimento com abatimento nulo fabricados no Brasil e com grande utilização, como adoquines (blocos maciços de concreto destinados à pavimentação intertravada), e tubos de concreto simples ou armados utilizados na infra-estrutura sanitária e drenagem de terrenos.

Existem ainda no mercado outros artefatos, como telhas de concreto, vasos de planta, guias de calçadas, postes, moirões, bocas de lobo, tampas de caixas de inspeção, elementos arquitetônicos vazados para paisagismo. No que se refere a grandes volumes, o mesmo autor cita as construções de estradas com pavimento rígido e barragens hidrelétricas, as quais são produzidos com a tecnologia do concreto compactado a rolo (CCR). 


\subsubsection{Conceitos de concreto compactado a rolo}

Este tipo específico de concreto possui consistência rígida no estado fresco e baixo teor de água, que exigem elevada energia de vibração externa e de compactação para ser adequadamente adensado. Estas características possibilitam uma concretagem ininterrupta e desmoldagem imediata, utilizando rolos vibratórios da técnica de pavimentação de estradas.

O concreto produzido com a técnica do CCR pode ser utilizado na produção de blocos de concreto para alvenaria, devido à semelhança do processo que permite a desmoldagem imediata após o adensamento da mistura. Além da característica deste processo, suas propriedades são semelhantes às do concreto com consistência plástica, como baixa permeabilidade, alta resistência ao intemperismo, e elevada resistência à compressão e ao cisalhamento, conforme Figura 2. 22.

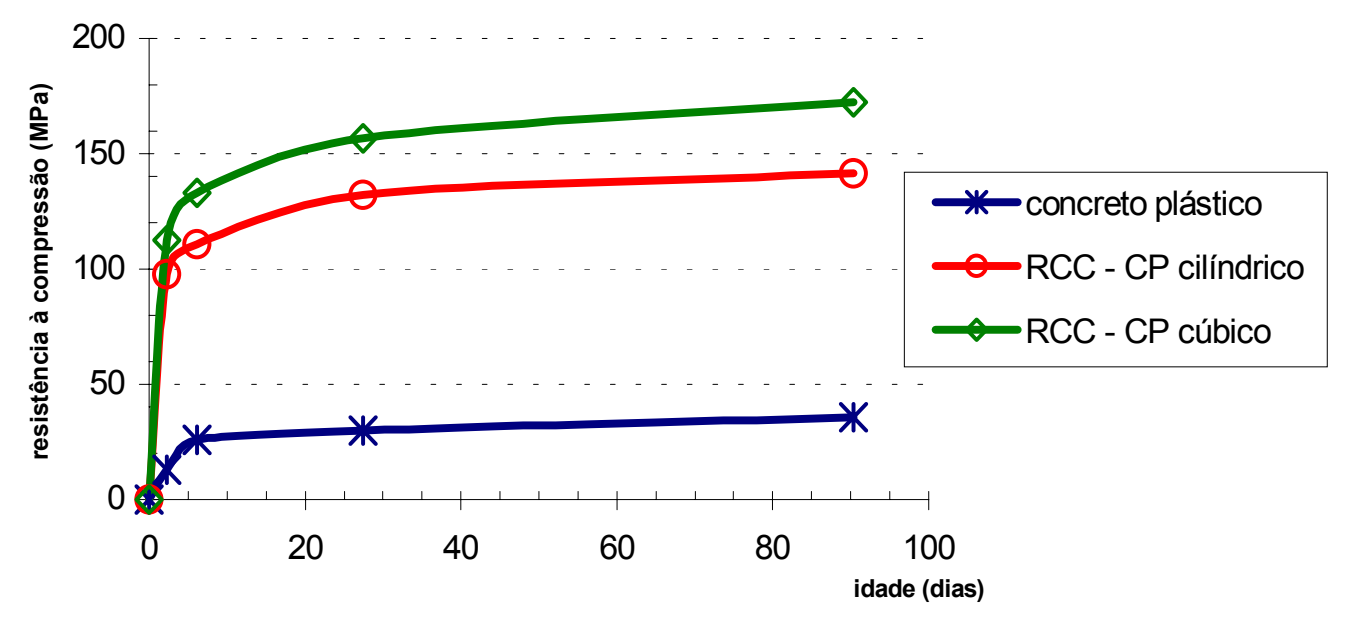

Figura 2.22 - Resistência simples à compressão do concreto compactado a rolo de elevado desempenho

FONTE: RIBEIRO \& ALMEIDA, 2000

A quantidade de pasta de cimento deve ser superior à quantidade mínima necessária para envolver as partículas dos agregados, sendo o restante do espaço ocupado por agregados e por vazios existentes na massa do concreto, ao qual depende do adensamento. Entretanto, o atrito, o formato dos agregados e a fluidez da pasta podem resultar no surgimento de bolhas de ar no interior do concreto no estado fresco. 
Segundo NeVILLE (1997), a relação entre agregado e cimento é um fator secundário na resistência do concreto, pois para a mesma relação água/cimento, misturas pobres em cimento podem resultar em resistências superiores. Este fato ocorre devido à maior quantidade de agregado, exigindo maior quantidade de água absorvida pelos agregados, reduzindo assim a relação água/cimento efetiva. Além disso, o aumento na quantidade de agregado, reduz a porcentagem de cimento que é responsável pela retração e exsudação, reduzindo a possibilidade de danos patológicos na aderência entre pasta de cimento e agregado, bem como variações térmicas oriundas da elevada liberação de energia de hidratação do aglomerante.

Os procedimentos que utilizam os conceitos de compactação de solo para escolher a umidade ótima de adensamento máximo para consistência seca, possibilitam encontrar limites específicos de consistência, garantindo que o volume de pasta exceda o volume de vazios dos agregados (HARDING, 1997).

A compactação deve ser efetuada enquanto a mistura estiver fresca e trabalhável. Devido à baixa quantidade de água, as forças externas precisam ser imediatamente aplicadas no concreto após o espalhamento. Embora não haja normas para determinar a consistência "in loco", uma boa indicação de que o concreto está pronto para a compactação é a observação de seu comportamento no estado fresco: se o concreto estiver muito úmido, a aparência do concreto será brilhante e pastosa devido à separação do excesso de água; se o concreto estiver muito seco a superfície será rugosa e granulada, conseqüentemente a vibro-prensa não deixará a impressão de ranhuras da pasta de cimento.

\subsubsection{Materiais}

Os materiais básicos utilizados são os mesmos dos concretos empregados em outras aplicações, como cimento, agregados e adições minerais (sílica). Entretanto, a técnica para dosagem de CCR necessita de um profundo conhecimento dos materiais utilizados, principalmente dos agregados. A Figura 2. 23 apresenta um exemplo de granulometria utilizada para a produção de blocos de concreto e 
adoquines (pavers). No entanto, deve-se atentar também à resistência dos agregados, e na diferença nos módulos de elasticidade dos agregados e da pasta de cimento, para evitar o surgimento de microfissuras na interface agregado-matriz (NEVILLE, 1997).

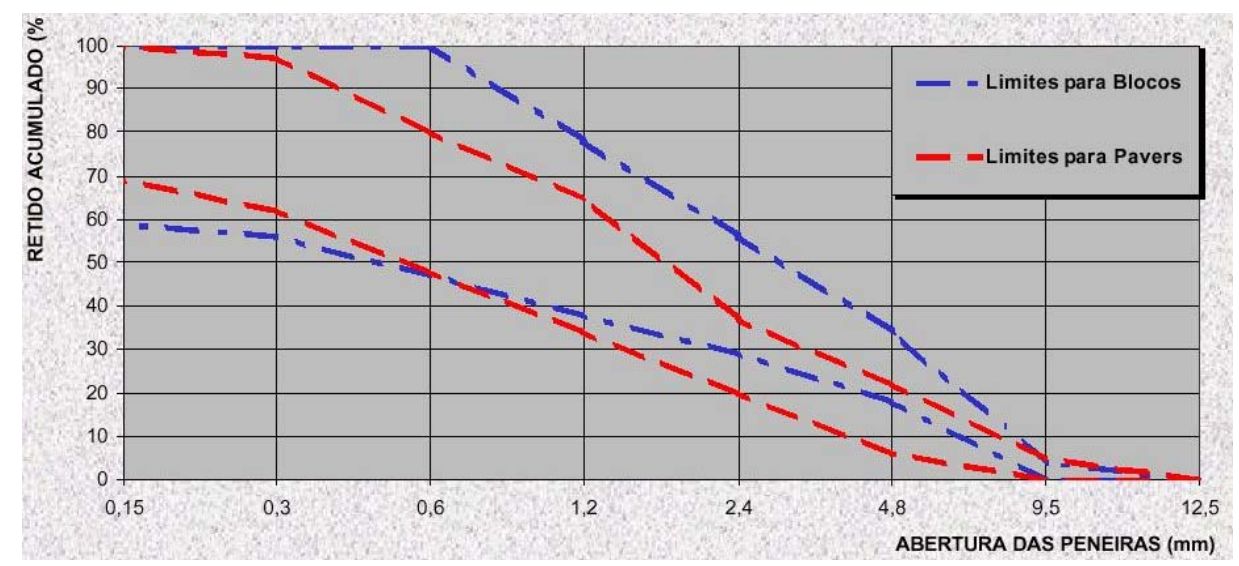

Figura 2.23 - Curvas granulométricas para produção de blocos de concreto e adoquines

FONTE: FERNANDES, 2001 $1^{14}$

\subsubsection{Métodos para medir a consistência}

A consistência, conforme mencionado anteriormente, é de total importância à produção de blocos de concreto para alvenaria. Segundo DIAZ (1998), os métodos mais utilizados para medir a consistência e a trabalhabilidade do concreto sem abatimento, são:

a) Cone de Abrams (Slump test): mede o assentamento. O tronco de cone de concreto se abate pelo seu próprio peso e a diminuição de altura é a medida da consistência do concreto. Deve-se lembrar que este método não dá valores de abatimento sensíveis e só é possível medir com ele abatimentos superiores a zero. É realizado segundo a NBR 7223/82;

14 FERnAndes, I.D. (2001). Produção de componentes vibro-prensados. In: SEMINÁRio NACIONAL SOBRE BLOCOS DE CONCRETO PARA ALVENARIA E PAVIMENTAÇÃo, São Paulo, Anais. São Paulo, ABCP/Instituto de Engenharia. 
b ) Mesa de queda: mede a fluidez, muito utilizado na Alemanha, França, Suíça e Estados Unidos. O cone é preenchido com a mistura fresca e submete-se a mesa à quedas verticais, segundo a NBR 13276/85. A fluidez é a relação entre o diâmetro médio (D) e o diâmetro da base maior (B). O inconveniente da mesa de queda é que não espalha o concreto uniformemente, mas de maneira desigual e dispersa os elementos mais grossos, o que torna difícil determinar o diâmetro médio;

c ) Consistômetro VeBe: desenvolvida pela Associação Sueca de Fabricantes de Cimento, mede a consistência de misturas de concreto a serem vibradas e serve para qualquer consistência, mesmo as misturas muito secas. Seu princípio se fundamenta na determinação do tempo necessário para transformar um tronco-cone de concreto num cilindro, por meio da vibração. Este equipamento consiste de um "Cone de Abrams" comum, colocado dentro de um recipiente cilíndrico e apoiado sobre uma pequena mesa vibratória elétrica, conforme Figura 2. 24. O cone é preenchido conforme a NBR7223/82. Após a retirada do mesmo, apóia-se o disco de acrílico, suspenso por uma haste graduada, sobre o tronco-de-cone de concreto. Aplica-se a vibração no recipiente até que se obtenha a nova configuração do recipiente cilíndrico, não apresentando vazios visíveis, anotando-se o tempo transcorrido em segundos. Este tempo é o número de graus de consistência VeBe.
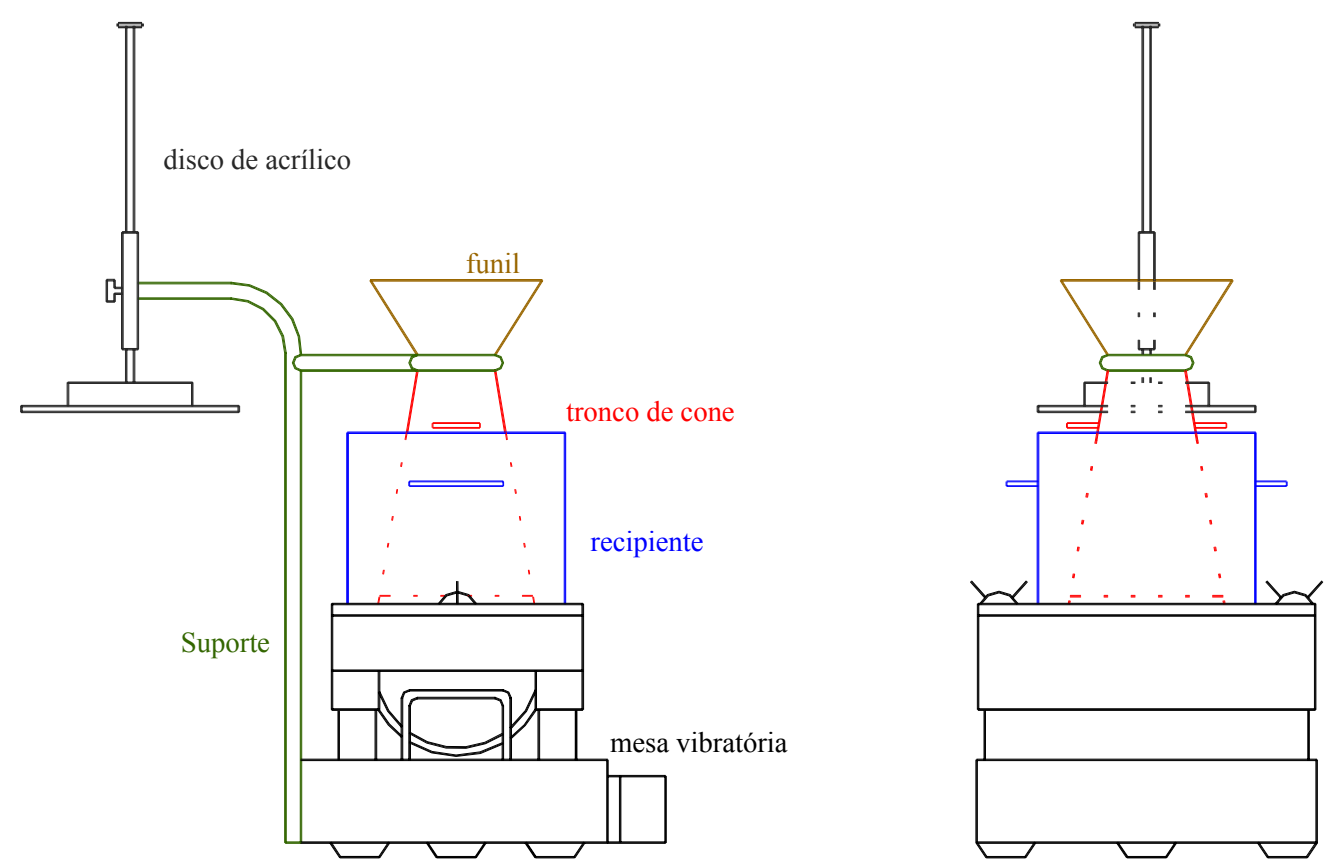

Figura 2.24 - Aparelho de VeBe

FONTE: DIAZ, 1998 


\subsubsection{Energia de vibração e resistência à compressão do elemento}

Segundo DiAz (1998), é um erro vibrar concretos muito fluidos, porque pode comprometer a qualidade. A vibração produz a liquefação aparente da massa, possibilitando o emprego de misturas secas nas regiões das estruturas com grande densidade de armaduras, onde normalmente se empregaria um concreto fluido de baixa resistência. A partir de uma certa plasticidade, a vibração não pode aumentar a compacidade do concreto e apenas auxilia sua colocação na forma, de maneira mais rápida e regular. Se nestas condições a vibração for prolongada, a segregação pode ocorrer, resultando na concentração da argamassa na parte superior.

O mesmo autor ressalta que, dependendo da energia de vibração, os concretos secos e rijos transformam-se numa massa fluida e viscosa, adquirindo propriedades de um líquido pesado, o que aumenta extraordinariamente a fluidez do ponto de vista mecânico.

Segundo NEvILLE (1997), "valores muito baixos da relação água/cimento, a curva deixa de ser seguida quando o adensamento pleno não é mais possível; o ponto real onde se inicia o afastamento da curva depende do meio de adensamento disponível". Para melhor compreensão, a Figura 2. 25 expõe o intervalo de validade da regra da relação água/cimento $\mathrm{X}$ resistência.

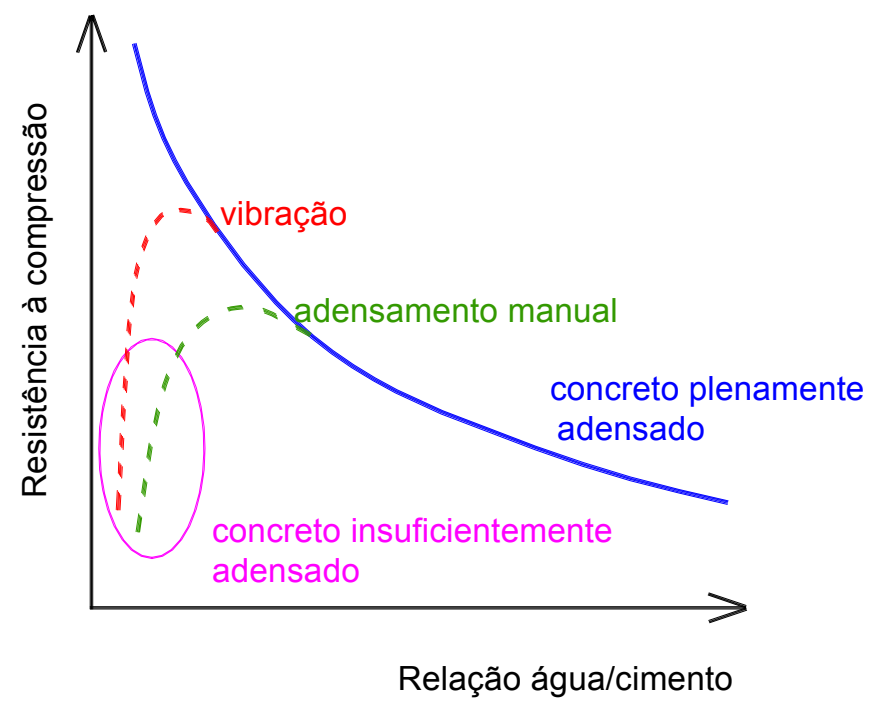

Figura 2.25 - Dependência entre a resistência e a relação a/c

FONTE: NEVILLE, 1997 
Para conferir o efeito da quantidade de água contida nos concretos sem abatimento, o gráfico da Figura 2. 26 mostra a variação relativa da resistência à compressão de um concreto em função da quantidade de água de amassamento empregada no seu preparo.

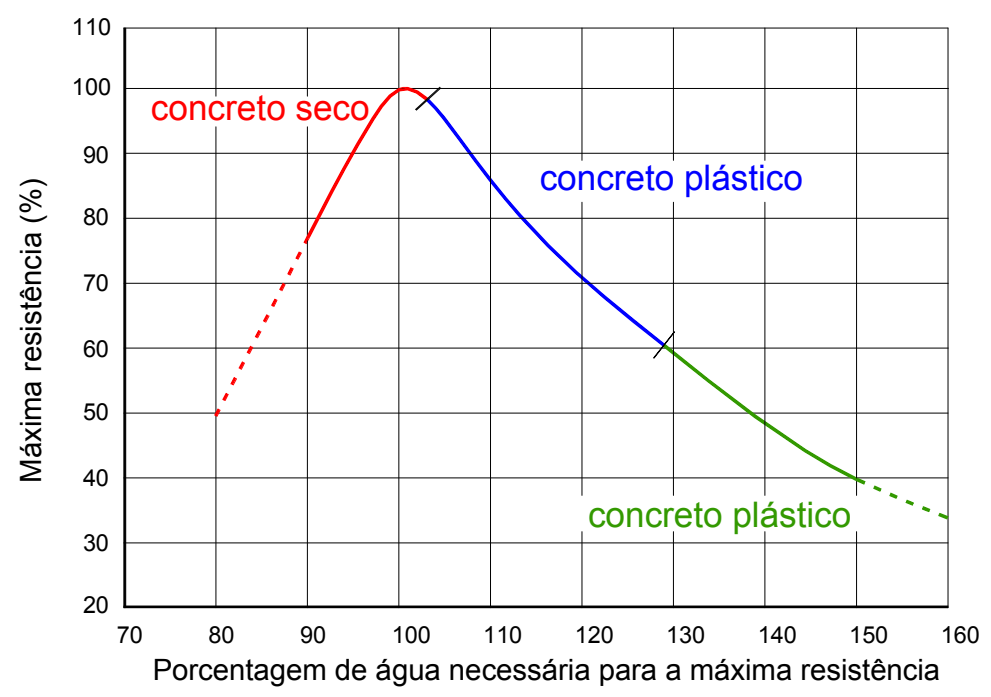

Figura 2.26 - Efeito da quantidade de água nos concretos

FONTE: ABREU, 2000

A resistência às tensões do concreto com abatimento nulo varia de forma aproximadamente linear com a dosagem de aglomerante, tal como é normal ocorrer em concretos convencionais, podendo apresentar, no entanto, valores bastante elevados, considerando a reduzida dosagem de aglomerante (RIBEIRO, 2000). Porém, esta prática somente é válida quando houver água de hidratação do cimento suficiente, caso contrário, parte do cimento será utilizado como filer, que não reagirá. Conseqüentemente, não haverá linearidade da resistência com o consumo de aglomerante.

\subsubsection{Controle do concreto e da concretagem}

É difícil determinar a quantidade de água livre em concretos com agregados leves. Segundo NeVILle (1997), quando se faz a dosagem de concretos utilizando agregados leves, a relação água livre/cimento depende da velocidade de absorção no momento da mistura e não apenas do teor de umidade do agregado. Isto 
ocorre devido ao grande número de vazios em seu interior, conseqüentemente sua porosidade reflete em um gradiente de absorção pela qual a água necessária de hidratação das partículas de cimento estará na superfície e em seu interior, ocorrendo assim perda de trabalhabilidade que pode proporcionar eventuais patologia.

A saturação do agregado antes da mistura produz queda de resistência de $5 \%$ a $10 \%$, comparado ao do agregado seco para igual trabalhabilidade e consumo de cimento, pois a água que é destinada à absorção servirá para dar trabalhabilidade durante o lançamento e adensamento. Isto ocorre por ser possível que a água absorvida pelo agregado, no momento da mistura, torne-se disponível para a hidratação adicional que ocorre na matriz da interface pasta-agregado, conseqüentemente aumentará a aderência localizada na penetração da pasta de cimento para o interior dos poros abertos na superfície das partículas do agregado entre o agregado e a matriz.

Entretanto, como o processo utiliza baixa relação água/cimento, é indispensável atentar-se a cura, pois utiliza apenas a água a ser quimicamente combinada e a interlamelar (Tabela 2.5). Sendo assim, qualquer intervenção climática, como a temperatura, umidade do ar e velocidade do vento, pode retirar pequena parcela da quantidade de água da mistura no estado fresco, possibilitando o surgimento das fissuras por retrações.

Segundo NeVILle (1997), a cura consiste no controle da temperatura e na entrada e saída de umidade para promover a hidratação do cimento. Mantendo-se o concreto o mais próximo possível da saturação, os produtos da hidratação preencherão os espaços da pasta fresca de cimento, inicialmente preenchidos com água. A hidratação da pasta de cimento pode ser garantida não apenas pela movimentação de água entre o concreto e o tanque de água, mas em ambientes cuja umidade relativa do ar permaneça constante e superior $80 \%$, além de ser protegido do sol e do vento. Em concretos com baixa relação água/cimento, a cura contínua nas primeiras idades é essencial, pois a hidratação parcial pode tornar os capilares descontínuos, impedindo que a água penetre no interior do concreto, mesmo com a cura reiniciada. A Tabela 2. 12 a seguir, apresenta os processos de cura mais utilizados para concretos com abatimento nulo. 
Tabela 2.12 - Processos de cura para concretos com abatimento nulo

\begin{tabular}{|c|c|c|c|}
\hline tipo de cura & utilização & vantagem & desvantagem \\
\hline membrana & $\begin{array}{l}\text { - misturas plásticas e com } \\
\text { baixa área superficial em } \\
\text { contato com o meio externo } \\
\text { - concreto compactado a rolo }\end{array}$ & $\begin{array}{l}\text { - impede a perda de água } \\
\text { para o exterior da peça }\end{array}$ & $\begin{array}{l}\text { - dissolve-se em } \\
\text { contato com água }\end{array}$ \\
\hline $\begin{array}{l}\text { aspersão de água } \\
\text { (cura natural) }\end{array}$ & $\begin{array}{l}\text { - concretos com relação } \\
\text { água/cimento inferior a } 0,5 \\
\text { - concreto compactado a rolo } \\
\text { - blocos e adoquines }\end{array}$ & $\begin{array}{l}\text { - eliminação de custos de } \\
\text { aquisição de equipamento, } \\
\text { manutenção e operação }\end{array}$ & $\begin{array}{l}\text { - grandes perdas por } \\
\text { quebra em transporte } \\
\text { - maior potencial de } \\
\text { retração na secagem } \\
\text { dos blocos }\end{array}$ \\
\hline a vapor & - blocos e adoquines & $\begin{array}{l}\text { - redução do potencial de } \\
\text { retração na secagem dos } \\
\text { blocos } \\
\text { - redução na quantidade do } \\
\text { estoque pela aceleração do } \\
\text { processo de hidratação } \\
\text { devido à alta temperatura } \\
\text { - boa produtividade }\end{array}$ & $\begin{array}{l}\text { - surgimento de } \\
\text { retração térmica } \\
\text { - descontinuidade } \\
\text { dos microporos, } \\
\text { impedindo a } \\
\text { continuidade da } \\
\text { hidratação }\end{array}$ \\
\hline
\end{tabular}

Em relação ao controle da temperatura, a ACI 308-92, menciona que os agregados não sofram choque térmico. Para isto, recomenda-se que a temperatura da água, presente no tanque ao qual será realizada a cura úmida contínua, pela imersão do elemento pré-moldado, não diferencie de $11^{\circ} \mathrm{C}$ da temperatura do concreto. A Tabela 2. 13 a seguir, determina o tempo mínimo para cura, segundo a norma européia ENV 206:1992 ${ }^{15}$.

Tabela 2.13 - Tempo mínimo de cura (dias)

\begin{tabular}{|c|c|c|c|c|c|c|c|c|c|c|}
\hline \multirow{2}{*}{\multicolumn{2}{|c|}{$\begin{array}{c}\text { endurecimento } \\
\text { temperatura do concreto }\left({ }^{\circ} \mathrm{C}\right)\end{array}$}} & \multicolumn{3}{|c|}{ rápido } & \multicolumn{3}{|c|}{ médio } & \multicolumn{3}{|c|}{ lento } \\
\hline & & 5 & 10 & 15 & 5 & 10 & 15 & 5 & 10 & 15 \\
\hline condições & sem sol, u.r. $\geq 80 \%$ & 2 & 2 & 1 & 3 & 3 & 2 & 3 & 3 & 3 \\
\hline durante a & sol ou vento médio u.r. $\geq 50 \%$ & 4 & 3 & 3 & 6 & 4 & 3 & 8 & 5 & 4 \\
\hline cura & sol ou vento forte u.r. $<50 \%$ & 4 & 3 & 2 & 8 & 6 & 5 & 10 & 8 & 6 \\
\hline
\end{tabular}

FONTE: ENV 206:1992 apud NEVILLE, 1997

Quanto ao controle de fissuras, TERZIAN (2001) relata que estas podem originar-se pela ação do clima e pela secagem rápida do material cimentício no estado fresco, além do consumo de cimento e da elevada temperatura originada pela hidratação do cimento. Segundo ábaco exposto na Figura 2. 27 pela ACI 308-92,

${ }^{15}$ ENV 206:1992. Concrete: Performance, production, placing and compliance criteria. 
fissuras provenientes da evaporação da água são influenciadas pela temperatura do ar e do material cimentício, da umidade relativa do ar e da velocidade do vento.

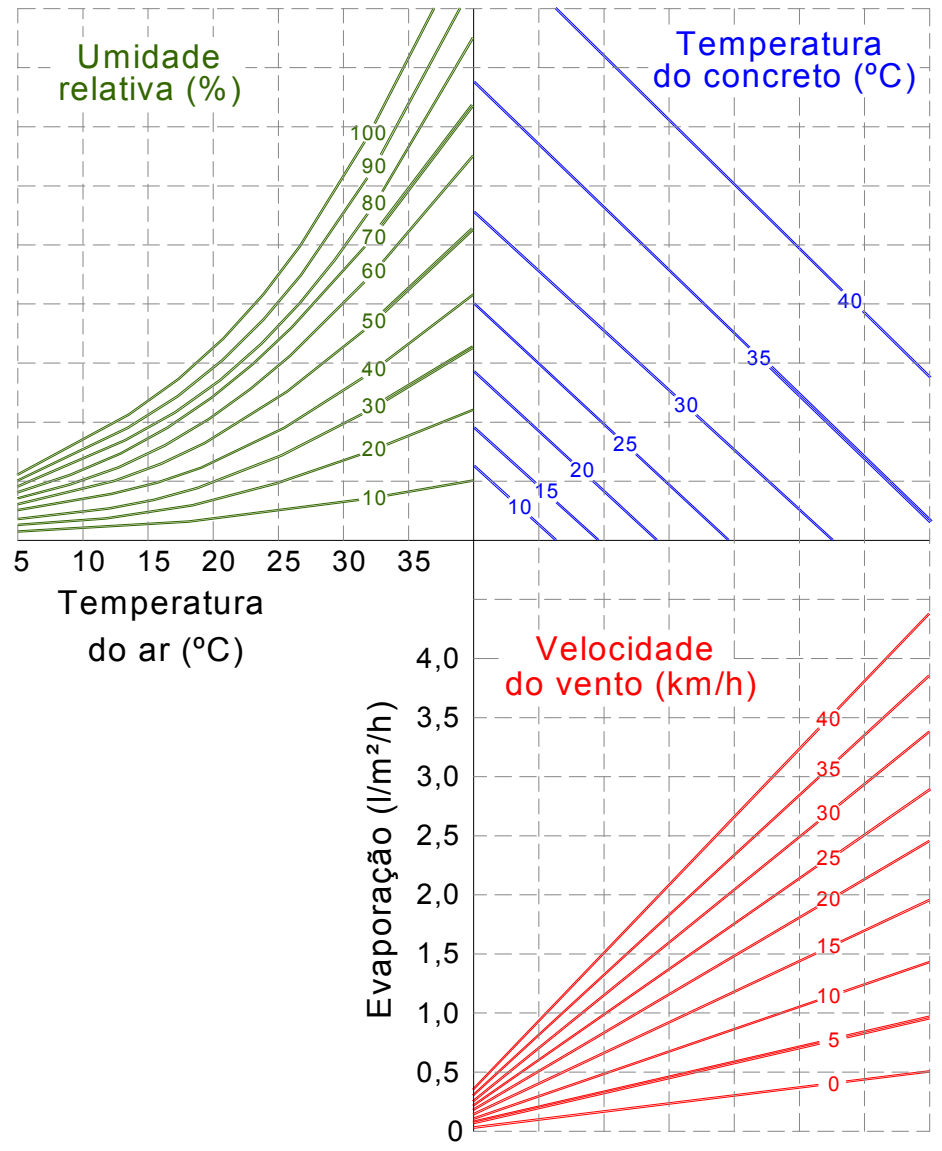

Figura 2.27 - Ábaco de tendência à fissuração do concreto

FONTE: ACI 308-92

\subsubsection{Metodologia de dosagem para concretos de abatimento nulo}

\subsubsection{Associação Brasileira de Cimento $\underline{\text { Portland }}$}

A proporção entre agregados baseia-se no ensaio de massa unitária do agregado segundo a NBR 7810/83, consistindo na comparação de massas das misturas de agregados que caibam em um recipiente padronizado, com volume conhecido. Preparam-se várias porções de amostras de agregados, sendo que cada porção possui um certo teor de um tipo de agregado, variando de 20 a $80 \%$ da massa total, em escalas de $10 \%$. Depois de misturada cada porção, determina-se a massa 
unitária, cuja melhor proporção entre os agregados corresponde à que possua a maior massa específica aparente. Na hipótese de serem utilizados mais que dois agregados, este método continua sendo válido.

A escolha da relação agregado-cimento (m) mais adequada, é obtida com maior eficiência pela determinação do ensaio à compressão de corpo-de-prova, com teores de cimento diferentes.

Ao contrário do concreto plástico, os concretos com abatimento nulo devem possuir a máxima quantidade de água, para a mesma consistência rígida, para permitir a hidratação do cimento, trabalhabilidade adequada ao concreto e boa aparência das peças recém fabricadas. Desta forma, colocam-se os materiais secos no misturador e adiciona-se água, até que seja possível moldar as peças e observar as superfícies laterais, que devem apresentar minúsculos veios d'água. Outro método para determinar o consumo de água é moldar corpos-de-prova com umidade variável, pesando-se após a moldagem, cuja quantidade ótima será a que fornecer a amostra com maior massa.

\subsubsection{American Concrete Institute (ACI 211.3-75)}

Esse método baseia-se na quantidade de água em função do tipo de trabalhabilidade desejada, determinada através dos ensaios expostos na Tabela 2. 14.

Tabela 2.14 - Consistência do concreto

\begin{tabular}{c||c|c|c|c||c}
\hline \hline \multicolumn{1}{c||}{$\begin{array}{c}\text { descrição do } \\
\text { concreto }\end{array}$} & $\begin{array}{c}\text { trabalhabilidade } \\
\text { abatimento } \\
\text { (cm) }\end{array}$ & $\begin{array}{c}\text { tempo VeBe } \\
\text { (s) }\end{array}$ & $\begin{array}{c}\text { fator de } \\
\text { adensamento }\end{array}$ & $\begin{array}{c}\text { mesa de queda } \\
\text { (revolução) }\end{array}$ & $\begin{array}{c}\text { relativa de } \\
\text { água (\%) }\end{array}$ \\
\hline \hline extremamente seco & - & $32-18$ & - & $112-56$ & 78 \\
muito rijo & - & $18-10$ & 0,70 & $56-28$ & 83 \\
rijo & $0-3$ & $10-5$ & 0,75 & $28-14$ & 88 \\
plástico rijo & $3-8$ & $5-3$ & 0,85 & $14-7$ & 92 \\
plástico (referência) & $8-13$ & $3-0$ & 0,91 & $<7$ & 100 \\
fluido & $13-18$ & - & 0,95 & - & 106 \\
\hline \hline
\end{tabular}

FONTE: ACI 211.3-75

A água necessária $\left(\mathrm{kg} / \mathrm{m}^{3}\right)$ para a mistura pode ser obtida em função do diâmetro máximo do agregado graúdo, conforme mostra a Tabela 2. 15, além do 
formato das partículas e da granulometria dos agregados, da temperatura do concreto, do método de adensamento e da taxa de ar incorporada desejada.

Tabela 2.15 - Água de amassamento necessária

\begin{tabular}{c||c|c|c|c|c||c|c|c|c|c}
\hline \hline \multicolumn{1}{c||}{ consistência } & \multicolumn{4}{c||}{ sem ar incorporado (mm) } & \multicolumn{4}{c}{ com ar incorporado (mm) } \\
& 10,0 & 12,5 & 20,0 & 25,0 & 40,0 & 10,0 & 12,5 & 20,0 & 25,0 & 40,0 \\
\hline \hline extremamente seco & 180 & 170 & 160 & 150 & 140 & 155 & 150 & 140 & 135 & 125 \\
muito rijo & 185 & 185 & 170 & 160 & 150 & 170 & 160 & 150 & 140 & 135 \\
rijo & 200 & 195 & 180 & 170 & 155 & 175 & 170 & 160 & 150 & 140 \\
plástico rijo & 205 & 200 & 185 & 180 & 160 & 180 & 175 & 165 & 160 & 145 \\
plástico (referencia) & 225 & 215 & 200 & 195 & 175 & 200 & 190 & 180 & 175 & 160 \\
fluido & 240 & 230 & 210 & 205 & 185 & 215 & 205 & 190 & 185 & 170 \\
\hline \hline taxa de ar incorporado (\%) & 3 & 2,5 & 2 & 1,5 & 1 & 8 & 7 & 6 & 5 & 4,5 \\
\hline \hline
\end{tabular}

FONTE: ACI 211.3-75

A quantidade de agregado graúdo é definida utilizando-se a maior quantidade de agregados graúdos por unidade de volume do concreto, adequado ao lançamento e trabalhabilidade, cujos valores encontram-se na Tabela 2. 16. Ressaltase que os coeficientes são referentes ao concreto plástico com "slump" de 8 a $13 \mathrm{~cm}$.

Tabela 2.16 - Volume de agregado graúdo por metro cúbico de concreto

\begin{tabular}{|c|c|c|c|c|}
\hline \multirow{2}{*}{$\begin{array}{l}\text { diâmetro máximo } \\
\text { do agregado } \\
(\mathrm{mm})\end{array}$} & \multicolumn{4}{|c|}{$\begin{array}{l}\text { volume de agregado seco por unidade de volume de concreto } \\
\text { para diferentes módulos de finura de agregado miúdo }\end{array}$} \\
\hline & 2,40 & 2,60 & 2,80 & 3,00 \\
\hline 10 & 0,50 & 0,48 & 0,46 & 0,44 \\
\hline 12,5 & 0,59 & 0,57 & 0,55 & 0,53 \\
\hline 20 & 0,66 & 0,64 & 0,62 & 0,60 \\
\hline 25 & 0,71 & 0,69 & 0,67 & 0,65 \\
\hline 40 & 0,76 & 0,74 & 0,72 & 0,70 \\
\hline
\end{tabular}

FONTE: ACI 211.3-75

A Tabela 2. 17 expõe o fator de correção do agregado graúdo para obter as diferentes consistências do concreto, em função do seu volume.

Tabela 2.17 - Fator de correção de agregados graúdos

\begin{tabular}{c||c|c|c|c|c}
\hline \hline \multicolumn{1}{c||}{ consistência } & \multicolumn{5}{c}{ fator para agregado com tamanho máximo } \\
& $10 \mathrm{~mm}$ & $12,5 \mathrm{~mm}$ & $20 \mathrm{~mm}$ & $25 \mathrm{~mm}$ & $40 \mathrm{~mm}$ \\
\hline \hline extremamente seco & 1,90 & 1,70 & 1,45 & 1,40 & 1,30 \\
muito rijo & 1,60 & 1,45 & 1,30 & 1,25 & 1,25 \\
rijo & 1,35 & 1,30 & 1,15 & 1,15 & 1,20 \\
plástico rijo & 1,08 & 1,06 & 1,04 & 1,06 & 1,09 \\
plástico (referência) & 1,00 & 1,00 & 1,00 & 1,00 & 1,00 \\
fluido & 0,97 & 0,98 & 1,00 & 1,00 & 1,00 \\
\hline \hline
\end{tabular}


Diferentes tipos de agregados, particularmente no formato das partículas, com volume seco de agregados, exigem diferentes quantidades de argamassa, refletindo assim em conteúdo de vazios. Os agregados angulares, rugosos e porosos como brita, e agregados reciclados, têm grande quantidade de vazios, exigindo, conseqüentemente, maior quantidade de argamassa que os agregados com formato circular (seixo rolado).

A quantidade de cimento a ser utilizada na dosagem é definida em função da resistência à compressão que se deseja obter dos corpos-de-prova. A Tabela 2. 18 representa a estimativa da resistência em função da relação água/cimento e da existência ou não de ar incorporado.

Tabela 2.18 - Relação entre a relação água/cimento e resistência à compressão

\begin{tabular}{c||c|c}
\hline \hline \multicolumn{1}{c||}{$\begin{array}{c}\text { resistência à compressão } \\
\text { aos 28 dias (MPa) }\end{array}$} & \multicolumn{2}{c}{ relação água/cimento (massa) } \\
sem ar incorporado & com ar incorporado \\
\hline \hline 50 & 0,33 & - \\
45 & 0,38 & - \\
40 & 0,43 & 0,34 \\
35 & 0,48 & 0,40 \\
25 & 0,55 & 0,46 \\
20 & 0,62 & 0,53 \\
15 & 0,70 & 0,61 \\
\hline \hline
\end{tabular}

FONTE: ACI 211.3-75

A mesma norma comenta que o formato das partículas e a textura de miúdos e graúdos influenciam na consistência, pois a falta de mais de $40 \%$ de agregado graduado indica material áspero e angular que provavelmente exigirá maior quantidade de água para corrigir a falta de lubrificação entre agregados. 


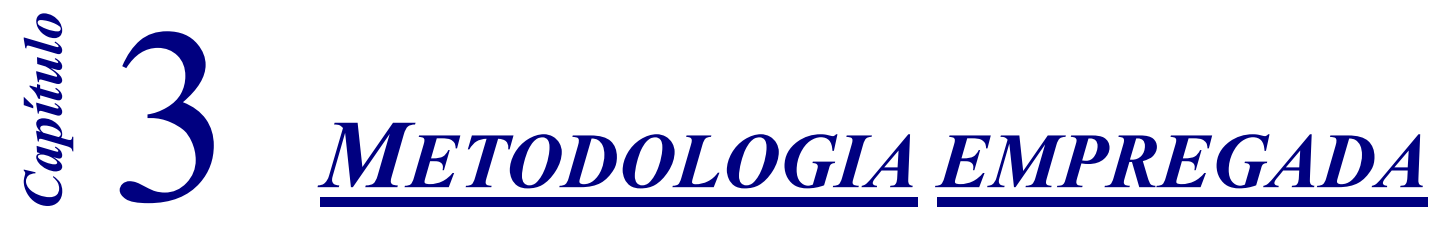

\subsection{Estudos preliminares}

Esta etapa tem como propósito determinar a dosagem destinada à fabricação do bloco de concreto e argamassas com agregado natural e reciclado. Para isto foi necessário fazer vários estudos de dosagem de concreto com abatimento rijo para bloco estrutural de concreto, cuja resistência à compressão fosse superior à mínima estrutural de 4,5MPa, além de apresentarem aparência, textura e absorção de água (inferior a 10\%) em conformidade com as normas brasileiras vigentes.

Devido ao pequeno estoque de agregados de RCD pertencente ao Laboratório de Estruturas, necessitou-se obter mais agregados de mesma origem. Depois de coletados aproximadamente $4,0 \mathrm{~m}^{3}$ na Usina de Reciclagem de Entulho da cidade de Ribeirão Preto, o novo lote foi dividido em 3 diferentes granulometrias: inferior a 2,4mm, 2,4 a $4,8 \mathrm{~mm}$ e 4,8 a $9,5 \mathrm{~mm}$ de dimensão máxima característica. 
Cada uma destas 3 frações foi caracterizada quanto às massas específicas e unitárias, curvas granulométricas e, sempre que possível, sua absorção.

Quanto às argamassas, analisaram-se suas resistências à compressão e tração por compressão diametral de distintos traços, para que fosse possível escolher, em função do menor consumo de cimento, qual resulta em melhor desempenho.

\subsection{Execução de ensaios em $\underline{\text { elocos, prismas }} \underline{\text { e painéis }} \underline{\text { de }} \underline{\text { alvenaria }}$}

Esta etapa teve como objetivo determinar os desempenhos mecânicos das paredes de alvenaria produzidos com agregados de RCD, variando dois tipos de argamassa mistas de assentamento em função do agregado utilizado: natural $(\mathrm{N})$ e reciclado $(\mathrm{R})$.

Para verificar a influência do revestimento no desempenho da alvenaria à compressão e com a possibilidade de combinar os 2 tipos de argamassas, foram ensaiados 3 tipos de paredes, segundo a NBR 8949/85, para cada tipo de argamassa: parede sem revestimento, parede assentada e revestida com a mesma argamassa, e parede assentada e revestida com argamassas distintas. Dentre as 6 séries de paredes, cada uma possuiu 3 exemplares para que se apresentassem resultados significativos, totalizando 18 paredes. Para correlacionar os comportamentos mecânicos entre blocos e painéis de alvenaria, cada parede possuiu seu respectivo prisma, assentado com a mesma argamassa, conforme a NBR 8215/83, porém sem revestimento. Ressalta-se que cada prisma possui 3 blocos de altura para que a resistência do elemento seja mais representativa à parede de alvenaria.

Nos ensaios de prismas e paredes, utilizou-se como capeamento, placas de forro produzidas com fibras de madeira reconstituída do tipo "soft-board" com espessura de 10mm, recomendada pela norma Britânica BS 5628 - part 1 (1978) e justificada pela dificuldade encontrada em realizar o capeamento com enxofre e argamassa devido ao peso, transporte e manuseio. Com grande capacidade de 
deformação, estas placas permitem corrigir com eficiência, os efeitos das imperfeições do bloco e distribuir uniformemente o carregamento ao longo da seção atuante, além de reduzir o tempo de preparo do corpo de prova para o ensaio e diminuir os efeitos de confinamento das chapas da máquina de ensaio, apresentando resultados mais próximos aos reais.

Para isto, foram produzidas paredes quadradas com $80 \mathrm{~cm}$ de aresta, diferentes da dimensão descrita por Pimienta \& DelmotTe (1998), para que fosse possível realizar o ensaio na Máquina Universal de Ensaios. As paredes foram construídas sobre calço de madeira para facilitar seu transporte, com fio de prumo e régua de nível, garantindo o prumo e uma superfície plana. A argamassa de assentamento foi colocada sobre toda a superfície útil dos componentes, com espessura final das juntas igual a $(10 \pm 3) \mathrm{mm}$.

As paredes e prismas revestidos receberam chapisco com traço 1:3 de cimento e areia, em volume, com quantidade de água especificada e mantida pelo pedreiro, para simular a execução em obra. Para evitar a retração da argamassa de assentamento e de revestimento, fez-se a cura por aspersão de água até o terceiro dia de idade do revestimento. Cada parede possuía suas respectivas amostras de corposde-prova cilíndricos $5 \times 10 \mathrm{~cm}$ de argamassa, confeccionados após o assentamento da primeira e terceira fiadas de assentamento e mais duas durante a aplicação do revestimento.

Para obter o módulo de deformação através da curva de tensãodeformação dos blocos, instalaram-se dois transdutores nos blocos intermediários dos prismas e paredes $(5,6)$, e mais quatro transdutores digitais em cada parede $(1,2$, $3,4)$, para determinar os encurtamentos médios, possibilitando obter o módulo de deformação através da curva média tensão-deformação, conforme Figura 3. 1.

As paredes foram ensaiadas aplicando-se cargas uniformemente distribuídas através de uma viga metálica tipo I, conforme encontra-se na Figura 3. 2. Os ensaios de resistência à compressão e determinação do módulo de deformação foram realizados na prensa com dispositivo servo-hidráulico INSTRON, que possibilita controlar a velocidade do deslocamento do pistão. 


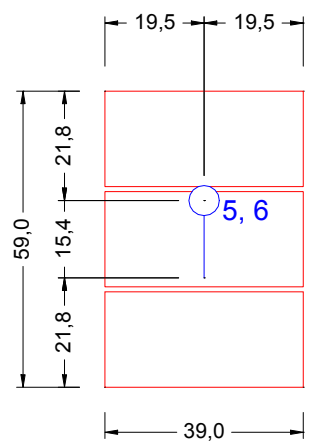

Prisma sem revestimento

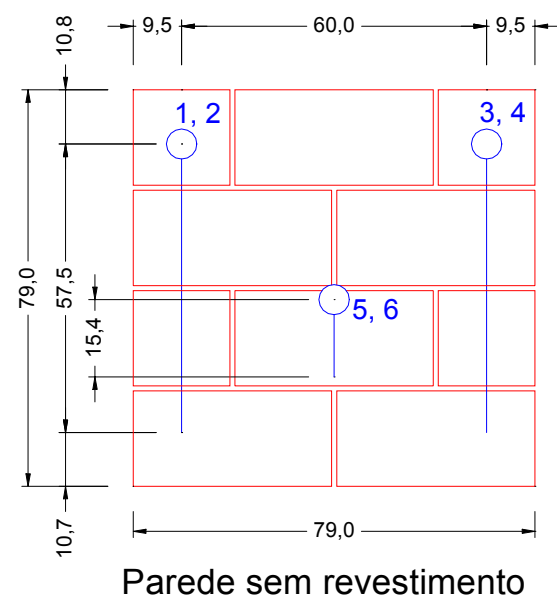

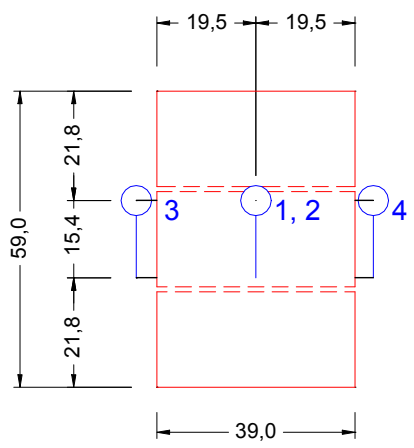

Prisma com revestimento

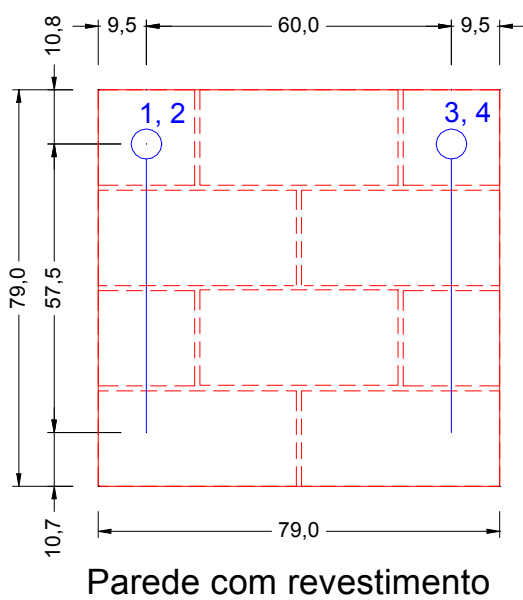

Figura 3.1 - Posicionamento dos transdutores nos prismas, paredes sem e com revestimento

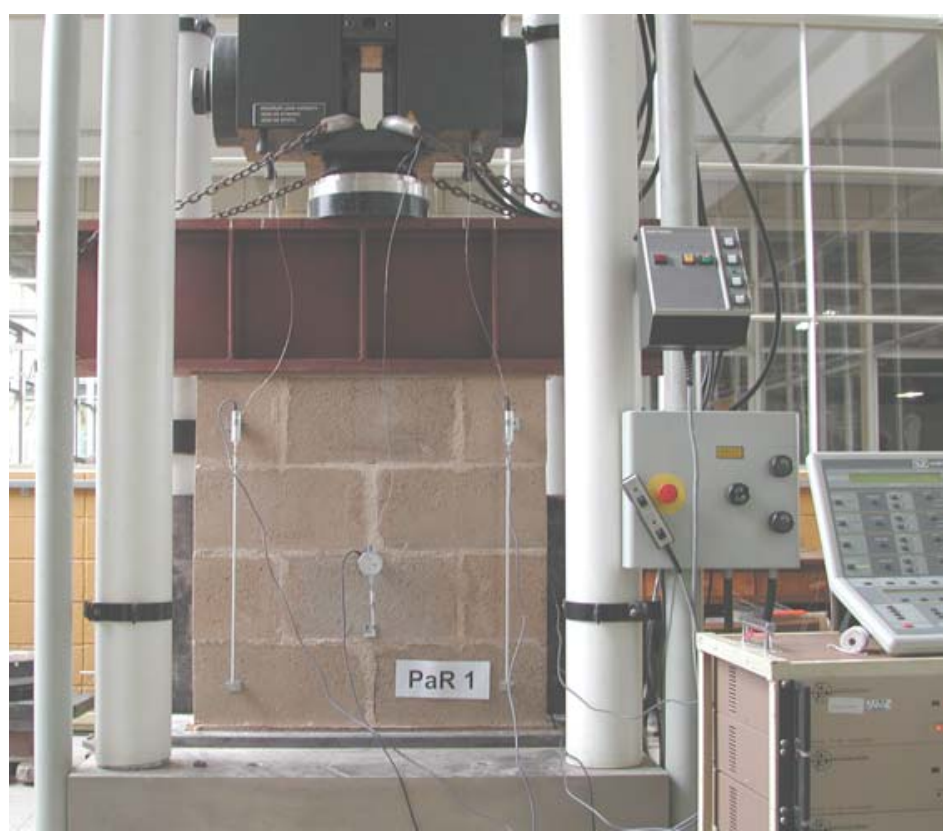

Figura 3.2 - Posicionamento da viga de distribuição na parede de alvenaria instrumentada ao pórtico de reação 
Foram aplicadas cargas de escorvamento de um estágio de $20 \mathrm{kN}$ para prismas e de dois estágios de $65 \mathrm{kN}$ e $120 \mathrm{kN}$ para paredes, com a finalidade de promover uma acomodação da alvenaria à argamassa de assentamento e ao capeamento. A velocidade de carregamento aplicada para ambos foi de $0,005 \mathrm{~mm} / \mathrm{s}$, com aquisição de dados dos deslocamentos dos transdutores efetuada pelo SISTEM 5000, com 1 leitura a cada segundo.

\subsection{Execução de ensaios em argamassas}

Esta etapa compreende os ensaios que determinam a resistência à aderência das argamassas de revestimento de paredes e o módulo de deformação secante de cada tipo de argamassa utilizada na construção de painéis de alvenaria.

\subsubsection{Resistência de aderência à tração das argamassas de revestimento}

A aderência entre o bloco e o revestimento de argamassa influencia no desempenho das alvenarias. Para determinar e esclarecer melhor o comportamento dos painéis revestidos que foram ensaiados à compressão, utilizou-se o método de ensaio segundo a NBR 13528/95. Este ensaio é baseado na força de tração que deve ser aplicada a um revestimento previamente delimitado, aderido a um painel, porém com pequena modificação devido ao equipamento utilizado, através de um braço de alavanca, exposto na Figura 3. 3. 


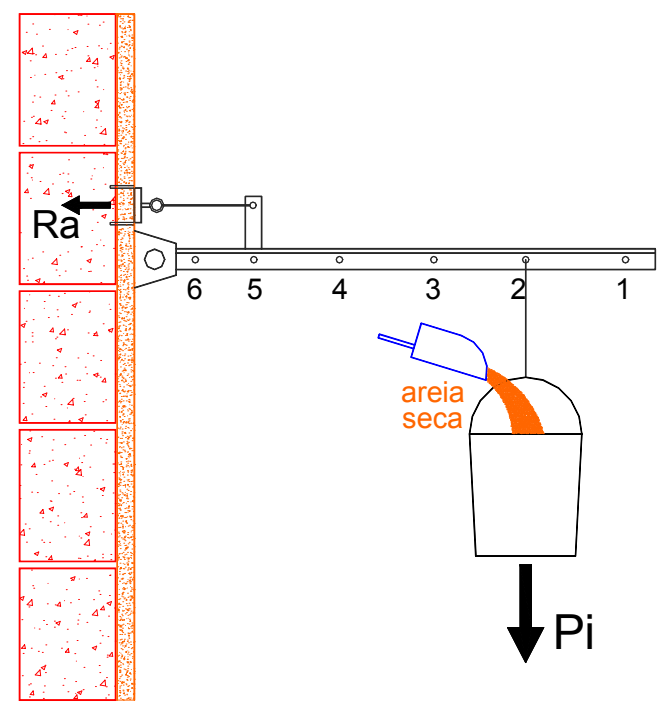

\section{Figura 3.3 - Ensaio de aderência de revestimentos}

A força (Ra) exercida pelo dispositivo de arrancamento do corpo-deprova do revestimento é expressa pela Equação 3. 1.

$$
\mathrm{Ra}=\sum \mathrm{P}_{\mathrm{i}} \cdot \mathrm{k}_{\mathrm{i}}+\mathrm{F}_{0}
$$

Onde

$\mathrm{P}_{\mathrm{i}}=$ peso aplicado no ponto genérico $\mathrm{i}$;

$\mathrm{K}_{\mathrm{i}}=$ constante do dispositivo no ponto genérico i;

$\mathrm{F}_{\mathrm{o}}=$ força transferida ao cabo devido ao peso próprio do dispositivo.

Foram confeccionadas duas paredes, cada uma assentada com um tipo de argamassa e com os lados, de cada parede, revestidos com um tipo de argamassa, representando assim os quatro tipos de paredes com revestimento presentes no ensaio de compressão. Com este ensaio, obteve-se subsídios para a análise da influência do revestimento no desempenho à compressão da parede.

A Figura 3. 4 expõe os componentes do ensaio de aderência à tração do revestimento de argamassa. 


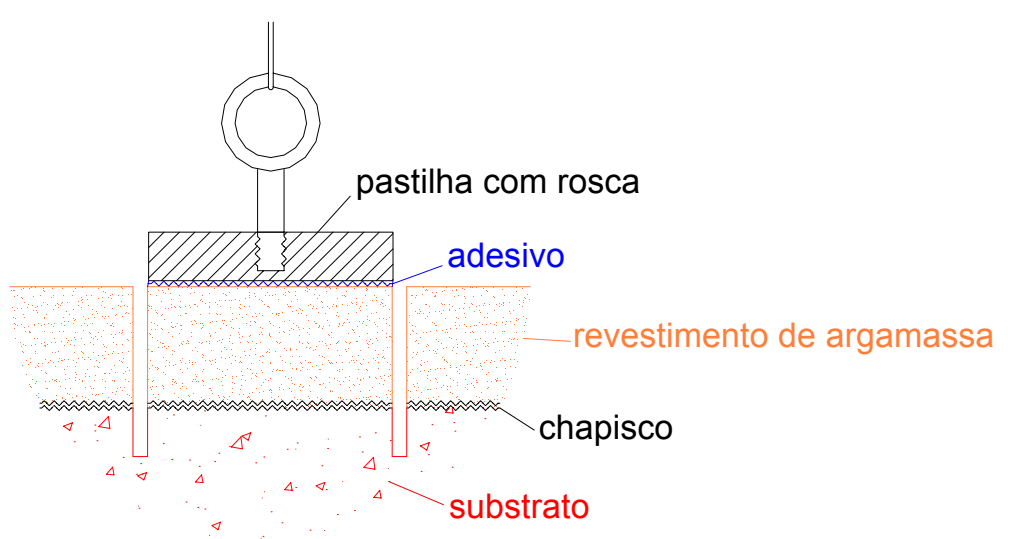

Figura 3.4 - Fases do corpo-de-prova do ensaio de aderência

FONTE: NBR 13528/95

Devido à possibilidade de que a ruptura nem sempre ocorra na interface entre o revestimento e o substrato, a NBR 13528/95 menciona que o cálculo da resistência média de aderência à tração e seu coeficiente de variação, devem ser realizados somente para pastilhas que apresentem a mesma forma de ruptura. A Figura 3. 5 exibe as possíveis formas de ruptura do corpo-de-prova.

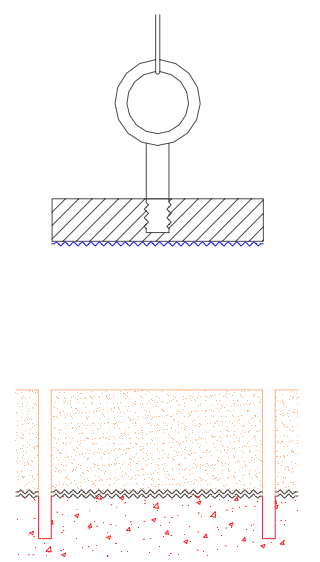

a) ruptura na interface revestimento/pastilha

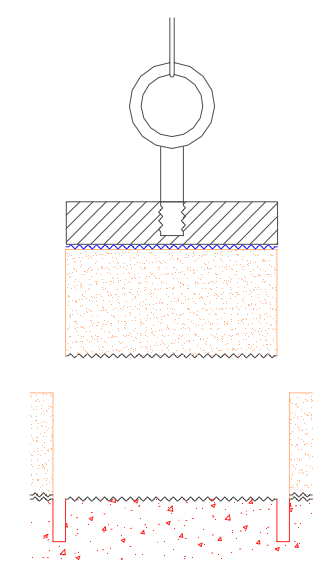

b) ruptura na interface revestimento/substrato

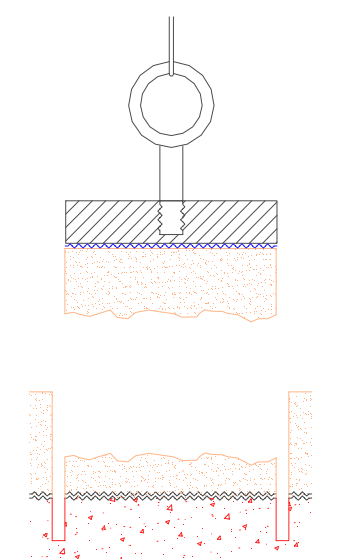

c) ruptura da argamassa de revestimento

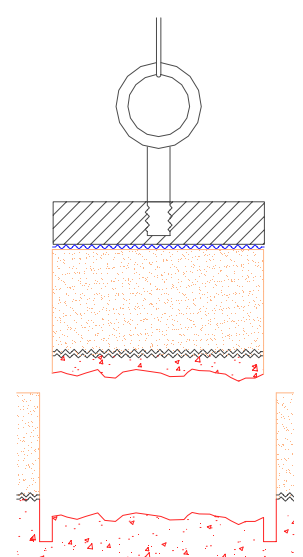

d) ruptura do substrato

Figura 3.5 - Formas de ruptura no ensaio de aderência à tração do revestimento

FONTE: NBR 13528/95

A Figura 3.5 (a) indica a imperfeição durante a colagem do epóxi aplicado para aderir a pastilha à argamassa, podendo ocorrer de 2 tipos: má aderência na interface cola/pastilha, cujo resultado deve ser desprezado devido à possibilidade 
da cola possuir baixa aderência; e a ruptura na interface revestimento/cola, cujo valor indica que a perda de aderência foi devida à superfície do revestimento.

Quando a ruptura for semelhante à Figura 3.5 (b), indica que a aderência entre revestimento/substrato é menor que a resistência à tração da argamassa. Pode ocorrer devido à fraca aderência entre o chapisco e o substrato de concreto ou alvenaria, ou entre o chapisco e a argamassa de revestimento. Neste último caso, a presença de fissuras ou a falta de contato são as principais responsáveis pelas resistências inferiores a $0,3 \mathrm{MPa}$.

Nos demais casos, a ruptura na argamassa de revestimento ou no próprio substrato representa que a resistência de aderência à tração é superior à resistência à tração dos mesmos.

\subsubsection{Módulo de deformação das argamassas}

Este ensaio baseia-se no método proposto pela NBR 8522/84 Determinação do módulo de deformação estática e diagrama tensão-deformação, para os quais foram empregados três corpos-de-prova cilíndricos com dimensões de 15 x 30cm, moldados e ensaiados com a idade referente ao ensaio à compressão axial dos prismas e paredes. Entretanto, a resistência à compressão das argamassas é muito inferior à do concreto. Ao utilizar corpos-de-prova com grandes dimensões, a velocidade estabelecida pela NBR $8522 / 84$ de $0,5 \mathrm{MPa} / \mathrm{s}$, resulta no carregamento de $8,8 \mathrm{kN} / \mathrm{s}$, resultando na dificuldade de aquisição de dados das leituras dos transdutores.

Para resolver este problema, recorreu-se à NBR 5739/80 - Ensaio de compressão de corpos-de-prova cilíndricos de concreto, que possibilita adotar um limite inferior e superior à taxa de carregamento, conforme mostra a Tabela 3. 1. Esta redução da velocidade de carregamento possibilitou obter deslocamentos suficientes para determinar o diagrama tensão-deformação. 
Tabela 3.1 - Velocidades de carregamento

\begin{tabular}{c||c|c|c||c|c|c}
\hline \hline \multicolumn{1}{c||}{ dimensão do $\mathrm{CP}$} & \multicolumn{3}{|c||}{ limite inferior } & \multicolumn{3}{c}{ limite superior } \\
& $\mathrm{f}_{\mathrm{c}}(\mathrm{MPa}) / \mathrm{s}$ & porcentagem & $\mathrm{F}(\mathrm{kN}) / \mathrm{s}$ & $\mathrm{f}_{\mathrm{C}}(\mathrm{MPa}) / \mathrm{s}$ & porcentagem & $\mathrm{F}(\mathrm{kN}) / \mathrm{s}$ \\
\hline \hline $5 \times 10$ & \multirow{3}{*}{0,3} & $60 \%$ & 0,6 & & & 1,0 \\
$10 \times 20$ & & & 2,4 & 0,8 & $160 \%$ & 6,3 \\
$15 \times 30$ & & & 5,3 & & & 14,4 \\
\hline \hline
\end{tabular}

FONTE: NBR 5739/80

\subsubsection{Profundidade de carbonatação das argamassas}

Como a presença e ausência de argamassas de revestimento, de naturezas distintas, podem influenciar nos resultados dos ensaios a serem realizados, devido o contato do dióxido de carbono na argamassa de assentamento das paredes e prismas, será verificada a profundidade de argamassa carbonatada em ambas as naturezas de argamassa.

Segundo PARIS (1973), o dióxido de carbônico, não reativo, ao penetrar lentamente nos poros úmidos do elemento, reage com a água, formando íons de hidrogênio e ácido carbônico (Equação 3. 2). Ao reagir com os álcalis presentes na solução, este ácido tem a capacidade de alterar as propriedades físico-químicas, como o aumento da resistência mecânica da estrutura, a redução do $\mathrm{pH}$ e a variação da porosidade da pasta, tornando-a mais permeável e com durabilidade reduzida da região carbonatada.

$$
\mathrm{CO}_{2}+\mathrm{H}_{2} \mathrm{O} \rightarrow \mathrm{H}^{+}+\mathrm{HCO}_{3}^{-} \rightarrow 2 \mathrm{H}^{+}+\mathrm{CO}_{3}^{-2}
$$

Mas ao mesmo tempo, o hidróxido de cálcio reage devido sua instabilidade química (Equação 3. 3).

$$
\mathrm{Ca}(\mathrm{OH})_{2} \quad \rightarrow \quad \mathrm{Ca}^{+2}+2 \mathrm{HO}^{-2}
$$

Estas duas reações se combinam, formando o carbonato de cálcio e água, conforme Equação 3. 4.

$$
\mathrm{Ca}^{+2}+2 \mathrm{HO}^{-2}+2 \mathrm{H}^{+}+\mathrm{CO}_{3}^{-2} \rightarrow \mathrm{CaCO}_{3}+2 \mathrm{H}_{2} \mathrm{O}
$$

No entanto, os cristais de carbonato de cálcio depositam-se a uma determinada distância da posição inicial do hidróxido de cálcio cristalino, resultando 
no preenchendo dos vazios, o que aumenta a compacidade, reduz a permeabilidade e aumenta a resistência da pasta carbonatada.

Desta forma, o desempenho mecânico de paredes com e sem revestimento de argamassa podem apresentar resistências incoerentes, uma vez que o revestimento dificulta a passagem de dióxido de carbono à argamassa de assentamento em uma direção, conforme Figura 3. 6.

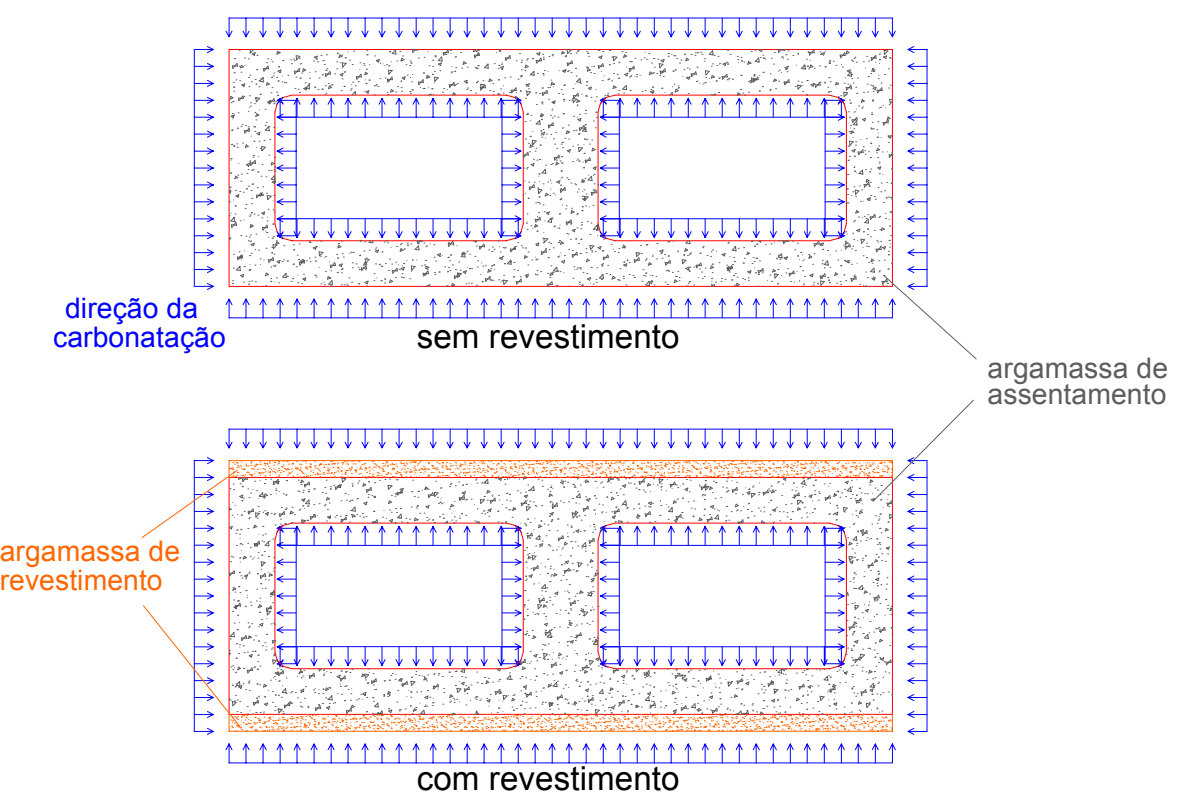

Figura 3.6 - Direção do efeito de carbonatação da argamassa de assentamento

A distinção da região carbonatada com a não carbonatada pode ser verificada com a mudança de $\mathrm{pH}$ da água dos poros da pasta de cimento. Como a carbonatação avança do exterior para o interior do concreto/argamassa, reduz o valor do $\mathrm{pH}$ de aproximadamente 12 para 8,3 na região carbonatada. No entanto, esta redução de $\mathrm{pH}$ pode acarretar na despassivação do aço, provocando a oxidação e corrosão das armaduras presentes no elemento estrutural. Segundo NUNES (1998), a elevada alcalinidade presente na região não carbonatada da solução aquosa presente nos poros do concreto, reage com a superfície da armadura, formando uma película passivadora. Esta proteção impede teoricamente que o processo de oxidação inicie, mesmo quando o concreto está exposto a elevadas umidades, devido ao contato permanente da pasta de cimento com a armadura, fornecendo íons de $\mathrm{Na}^{+}, \mathrm{K}^{+}, \mathrm{Ca}^{+2} \mathrm{e}$ $\mathrm{OH}^{-}$à armadura. Dessa forma, SILVA (2002) salienta que a carbonatação pode ser um fator para iniciar a corrosão devido ao consumo desses íons, porém não significa 
que a presença de um acarretará na do outro, pois a umidade relativa que mais favorece a carbonatação está em torno de $60 \%$ e a que mais favorece a corrosão excede $80 \%$.

Segundo RICHARDSON (1988), existem vários métodos para mensurar a profundidade de carbonatação, conforme se apresentam a seguir. No entanto, o método mais utilizado que baseia na determinação da profundidade da camada da amostra em que o processo de carbonatação não se iniciou, é o indicador ácido/base, cujo composto químico apresenta mudança de coloração em função do $\mathrm{pH}$ da superfície da amostra da pasta de cimento. A superfície dos corpos-de-prova ou das estruturas inspecionadas deve ser borrifada, na forma de névoa. Dentre os indicadores mais adequados, a fenolftaleina apresenta coloração modificada com $\mathrm{pH}$ superior a 9,2, cuja solução é composta por $1 \%$ de fenolftaleina com $70 \%$ de álcool etílico e $29 \%$ de água destilada. Este indicador, em contato com o hidróxido de cálcio presente nas regiões não carbonatadas, apresentam coloração púrpura, enquanto a presença de carbonato de cálcio existente nas regiões carbonatadas, não reage com os compostos.

Contudo, a profundidade carbonatada nem sempre é constante para o mesmo corpo-de-prova. SILVA (2002) relata que a carbonatação não é uniforme, necessitando, portanto, que se faça uma média entre as leituras, incluindo a profundidade carbonatada mínima, máxima e normal, durante a realização das medidas da espessura carbonatada. 


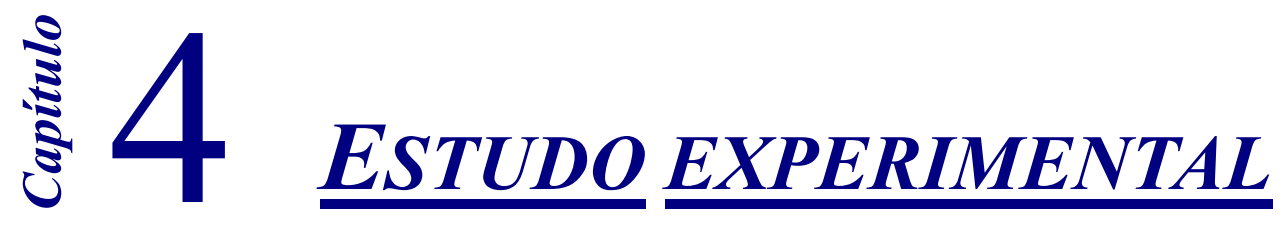

A utilização de agregados reciclados para a fabricação de artefatos de concreto e argamassa é o principal objetivo deste trabalho. Porém, como a natureza, a granulometria e as características físicas destes agregados são diferentes dos agregados naturais, é indispensável determiná-las.

Neste capítulo será exposto o desenvolvimento do traço de concreto com abatimento nulo a ser destinado à confecção de blocos vazados de concreto para alvenaria com função estrutural, utilizando agregados miúdos naturais e reciclados de fração entre $2,4 \mathrm{~mm}$ a $9,5 \mathrm{~mm}$ de diâmetro máximo.

Como grande parte dos agregados reciclados são constituídos pela fração passante pela peneira de $2,4 \mathrm{~mm}$ de abertura de malha, e devido a excelente resistência à compressão de argamassas produzidas com os mesmos agregados, relatados por vários estudos, foi realizado um estudo de traço de argamassa, referente ao comportamento estrutural, para utilizá-la no assentamento e no revestimento de painéis de alvenaria. 


\subsection{Processo de fabricação de blocos $\underline{\text { de }} \underline{\text { concreto }}$}

A única fábrica que produz blocos de concreto com função estrutural e que disponibilizou-se à produzir os blocos contendo agregado reciclado foi a Itaúna Blocos, localizada na rodovia SP 255, $\mathrm{km} 280$, pertencente ao município de Rincão e arrendada pela ARGASOL - Argamassa e artefatos de Concreto, do município de Araraquara. Utilizando uma Prensa Montana MBX 450 (Figura 4.1), produzida pela Trillor Máquinas em 1986, esta vibro-prensa tem a capacidade de produzir 3 blocos por chapa em 17 segundos.

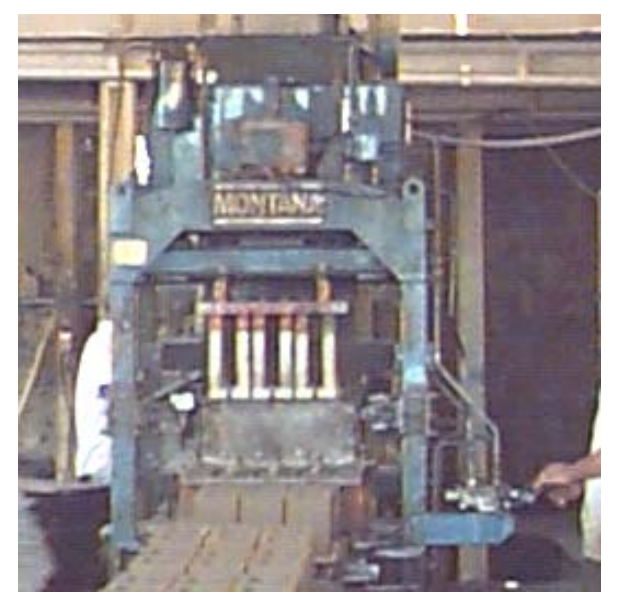

Figura 4.1 - Vista geral da prensa hidro-pneumática utilizada para confecção dos blocos de concreto com função estrutural

O mecanismo de dosagem utilizado consiste no depósito dos agregados e do cimento em silos, transportados por esteiras e dosados por meio de balanças adaptadas ao funil com capacidade para $500 \mathrm{~kg}$ e $300 \mathrm{~L}$ (Figura 4.2).

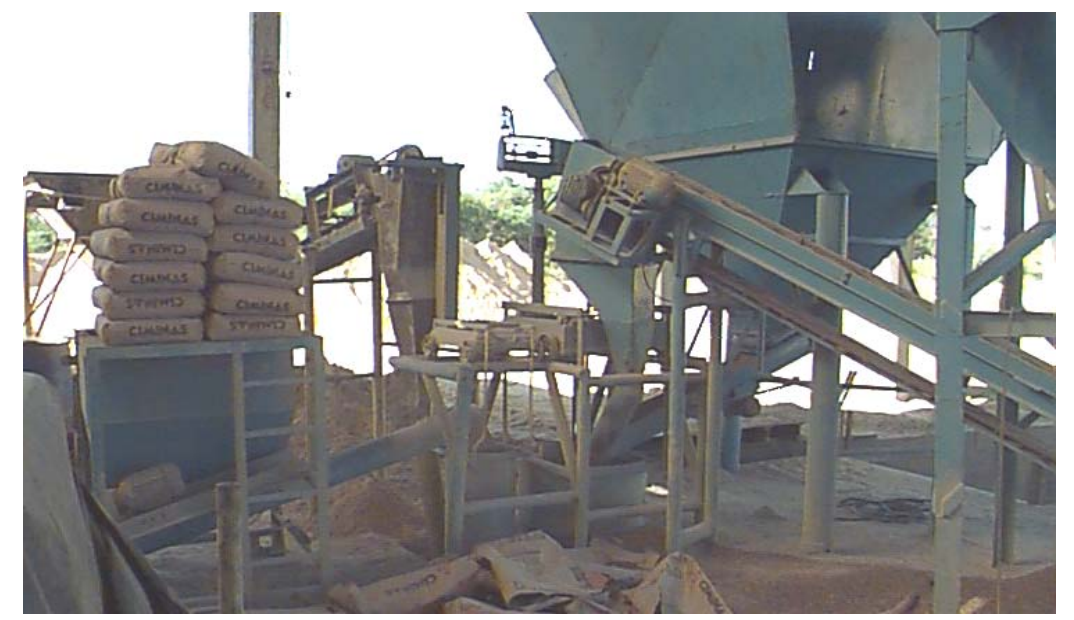

Figura 4.2 - Vista dos silos e balanças instalados no funil 
Os materiais são homogeneizados através de um misturador forçado de eixo horizontal com capacidade para $500 \mathrm{~L}$ em funcionamento permanente. Nesta etapa, despeja-se a água apenas após $30 \mathrm{~s}$ da mistura entre os agregados e as partículas de cimento, conforme Figura 4.3.

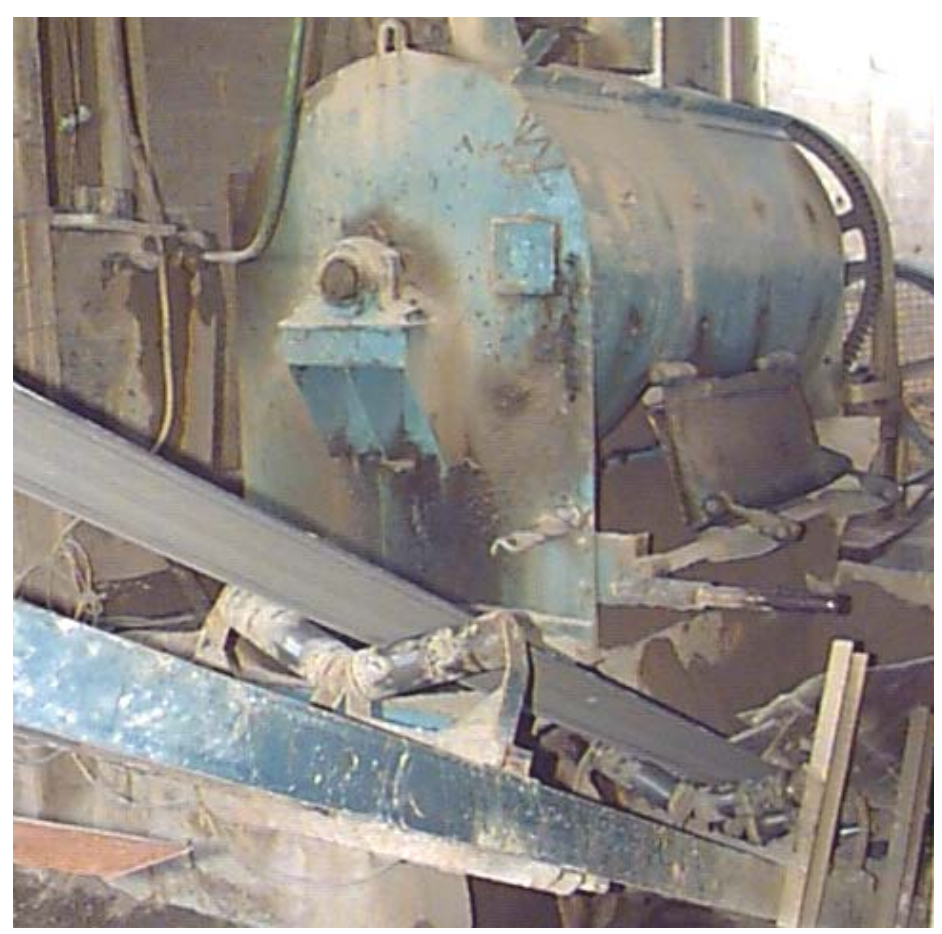

Figura 4.3 - Misturador forçado de eixo horizontal

O processo de moldagem dos blocos é composto por: lançamento do concreto, adensamento por vibração e compressão mecânica utilizando hastes, desforma do concreto, transporte aos pórticos de armazenamento e cura inicial, e cura dos blocos propriamente ditos. O concreto com aparência de "farofa" é lançado à fôrma previamente encostada na chapa de transporte do bloco, sendo adensado através da mesa vibratória que a sustenta (Figura 4.4a). Após o lançamento, aplica-se uma carga de $1.500 \mathrm{~kg}$ através de hastes que entram na forma, completando a energia de compactação (Figura 4.4.b), que é diretamente proporcional à resistência dos prémoldados produzidos com o concreto seco. Terminada a vibração da mesa, cessa-se a aplicação de carga das hastes de compactação, permanecendo estas imóveis para que, durante a desforma dos blocos, o deslizamento da fôrma não desagregue o bloco recém produzido (Figura 4.4c). Retiram-se as hastes de compressão (Figura 4.4d) e, através de um trilho de rodas, transporta-se o conjunto de 3 blocos, contido na chapa, ao pórtico de armazenamento e cura inicial ausente de insolação. 


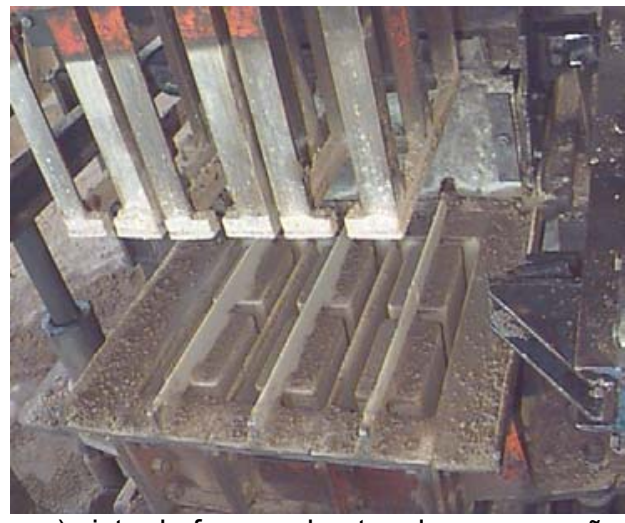

a) vista da forma e hastes de compressão

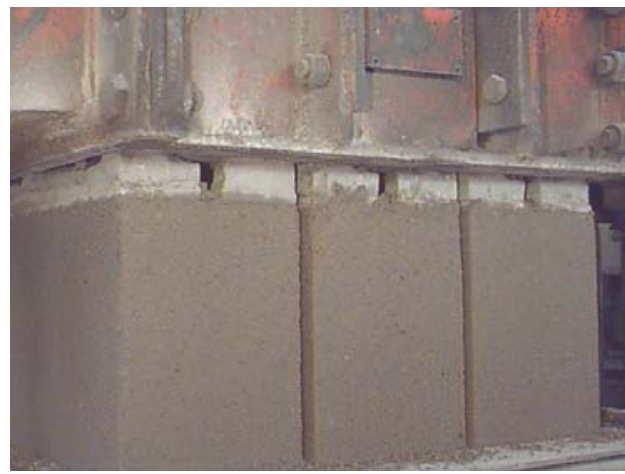

c) vista inferior da desforma

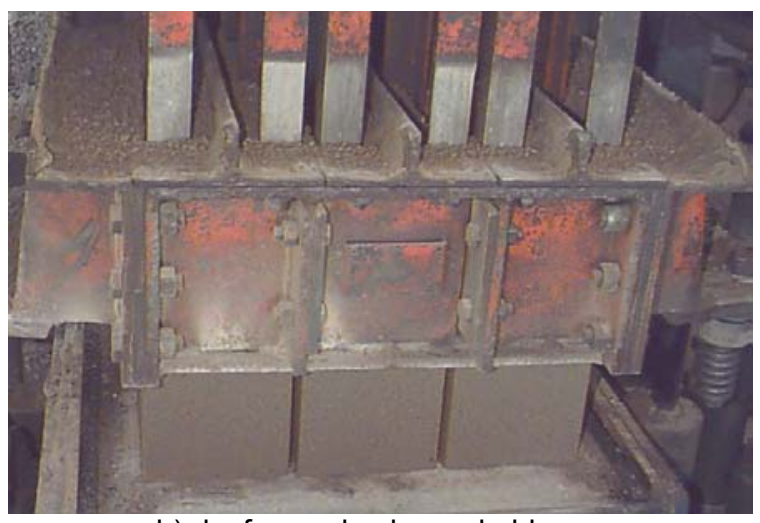

b) desforma da chapa do bloco

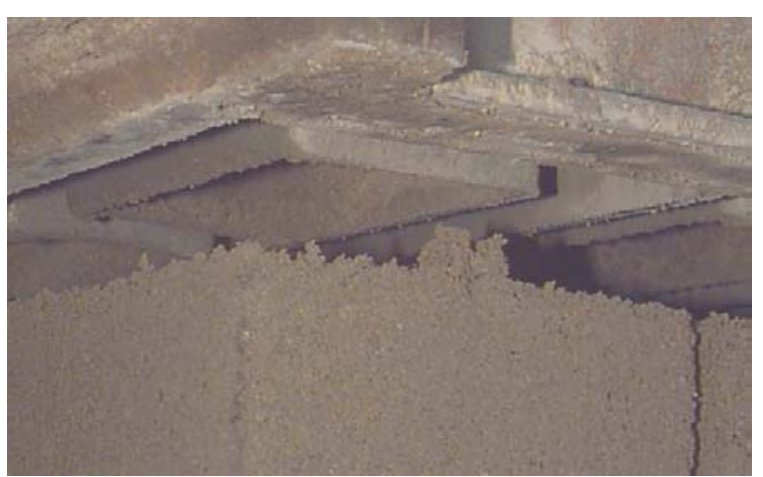

d) retirada das hastes de compressão

Figura 4.4 - Processo de moldagem dos blocos

Dependendo da prensa hidro-pneumática, os blocos de concreto podem conter algumas saliências resultantes do espaço entre as hastes de compressão (Figura 4.4d).

Após obterem uma resistência mínima ao transporte (30min), os pórticos são transportados ao pátio descoberto, onde permanecem de $15 \mathrm{hs}$ a $24 \mathrm{hs}$ para serem deslocados da chapa de sustentação e empilhados manualmente sobre palets, para serem armazenados (Figura 4.5) e curados com irrigação de água não contínua, sem proteção ao sol. Somente após o $7^{\circ}$ dia de idade, o lote é estocado para ser entregue ao consumidor. Conforme mencionado, esta fábrica possui baixo investimento de equipamentos, resultando na baixa produtividade de apenas 2,8 mil blocos diários. 


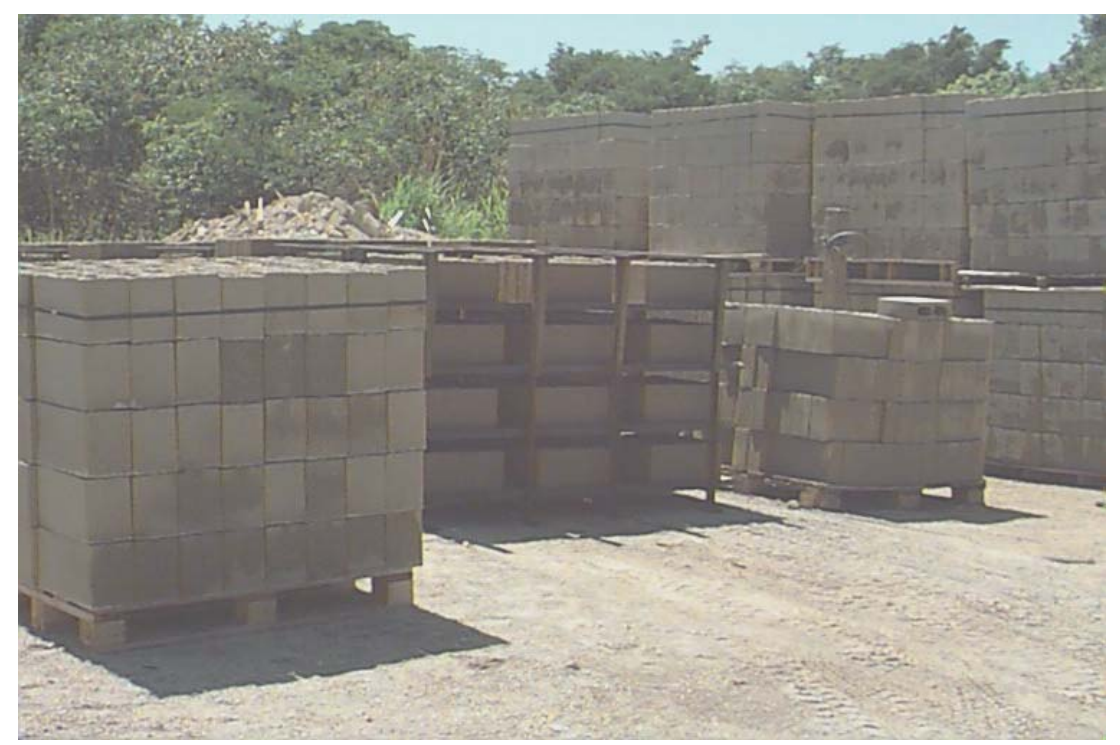

Figura 4.5 - Estocagem dos blocos

\subsection{Estudo de traço de blocos $\underline{\text { de }} \underline{\text { concreto }} \underline{\text { e argamassa }}$}

Segundo ABREU (2000), a dosagem do concreto para produção de prémoldados, como blocos de concreto para alvenaria, tem os seguintes objetivos: obter máxima compacidade, resistência mecânica compatível com as especificações, durabilidade compatível e aspecto superficial do pré-moldado aceitável.

Desta forma, ao utilizar um novo material, é preciso total conhecimento de suas propriedades. Esta etapa refere-se à caracterização dos agregados utilizados, composição de uma granulometria que reproduza um material com o menor índice de vazios e de baixo custo. 


\subsubsection{Bloco de concreto piloto}

\subsubsection{Características dos materiais utilizados para o estudo de bloco de concreto}

Para poder obter um concreto com bom controle de qualidade, separou-se o entulho em três frações. A Figura 4.6 expõe a curva granulométrica dos agregados naturais $(\mathrm{N})$ e reciclados $(\mathrm{R})$.

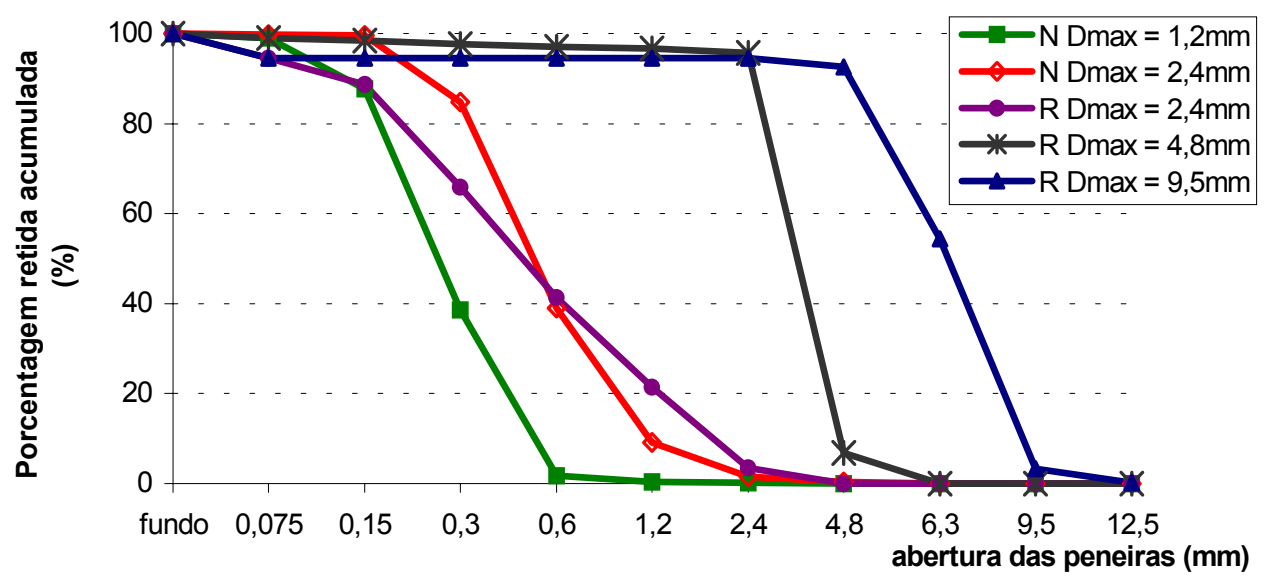

\section{Figura 4.6 - Curvas granulométricas dos agregados utilizados para estudo do bloco de concreto}

Para determinar as principais características dos agregados, utilizou-se a NBR 9776/87 para a determinação da massa específica de agregados miúdos por meio do frasco de Chapman. Devido à baixa densidade e à absorção da água do agregado reciclado, necessitou-se utilizar a Equação 4.1 de Chapman modificado.

$$
\gamma=\frac{500-x}{L-(200+x)}
$$

Onde:

$\mathrm{x}$ : valor que deve ser acrescentado à água e retirado da amostra do material, variando de 50 unidades.

A Tabela 4.1 apresenta as principais características dos agregados.

Tabela 4.1 - Características dos agregados utilizados para blocos de concreto e argamassa

\begin{tabular}{c||cc|ccc}
\hline \hline tipo do agregado & \multicolumn{2}{c|}{ natural } & \multicolumn{3}{c}{ reciclado } \\
\hline \hline dimensão máxima característica $(\mathrm{mm})$ & 1,2 & 2,4 & 2,4 & 4,8 & 9,5 \\
módulo de finura & 1,29 & 2,34 & 2,21 & 4,92 & 5,68 \\
\hline massa específica $\left(\mathrm{g} / \mathrm{cm}^{3}\right)-$ Chapman & 2,61 & 2,60 & 2,50 & 2,44 & 2,13 \\
massa unitária estado solto $\left(\mathrm{g} / \mathrm{cm}^{3}\right)$ & 1,50 & 1,42 & 1,36 & 1,05 & 1,11 \\
massa unitária seco compactado $\left(\mathrm{g} / \mathrm{cm}^{3}\right)$ & - & - & - & 1,23 & 1,27 \\
\hline \hline
\end{tabular}


Devido à necessidade de possuir abatimento nulo, utilizou-se o cimento CP V - ARI Plus, pois apresenta maior teor de finos em comparação a outros tipos de cimento, proporcionando maior consistência, possibilidade de desmolde imediato e alta resistência nos primeiros dias de idade, o que resulta em maior produtividade.

\subsubsection{Proporcionamento entre agregados}

Como o principal fator de resistência do concreto é a obtenção de uma granulometria ótima e econômica, procurou-se determinar o melhor proporcionamento dentre os agregados, sendo que o melhor método encontrado foi baseado no maior empacotamento proposto por HELENE \& TERZIAN (1995) e ABREU (2000). Como o concreto utiliza três granulometrias de agregados diferentes, sendo dois de agregados reciclados e uma de agregado natural, além de possuírem diferentes massas específicas e unitárias, traçaram-se curvas que demonstrassem a melhor composição granulométrica que proporciona a maior massa unitária. Primeiramente obteve-se a composição entre os reciclados devido à mesma natureza $(\mathrm{kg} / \mathrm{kg})$ e somente depois, acrescentando areia, obtiveram-se as curvas que demonstram a máxima massa unitária compactada, conforme Figura 4.7.

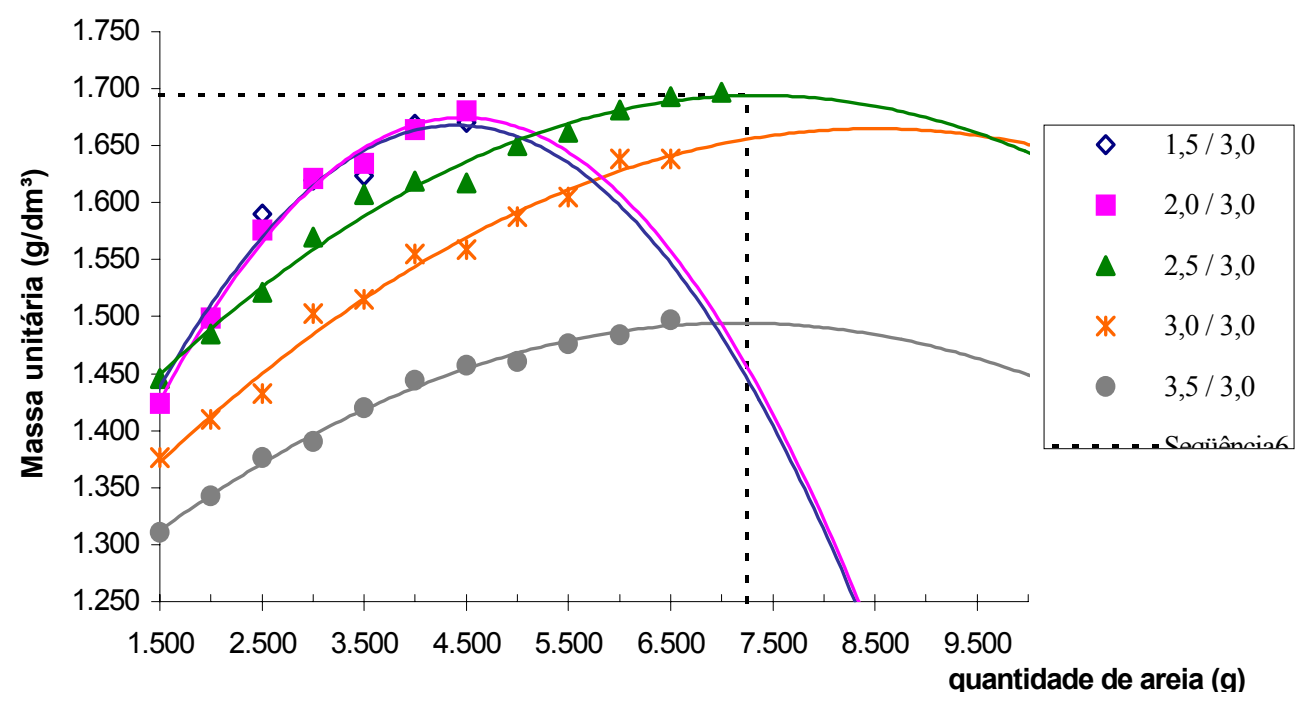

Figura 4.7 - Máxima massa unitária compactada dos agregados reciclados em relação à quantidade de areia

Observa-se que, devido à diferença de massa específica, bem como a diferentes fatores de forma, a relação 2,5 / 3,0, em massa $(\mathrm{kg})$, entre agregados 
reciclados de fração \#2,4-4,8 e \#4,8-9,5 respectivamente, com 7,25kg de areia, proporcionou a melhor composição entre agregados. Esta curva tem a vantagem de possuir pouca curvatura em seu pico, possibilitando o acréscimo da quantidade de areia para melhorar a textura superficial do bloco, sem alterar significativamente sua massa unitária.

Após ser composta a relação entre os agregados reciclados e a fração de \#1,2-2,4mm de areia, decidiu-se compor a fração natural por areia fina e média. A explicação de não ter sido determinada a composição do conjunto pelo método acima descrito, juntamente com a fração mais fina da areia, deve-se à grande dificuldade do ensaio para obter resultados representativos. Conforme indica o gráfico, quando a porcentagem de agregado natural for muito superior à do agregado reciclado, há uma incompatibilidade devido à diferença de massa específica e unitária, surgindo um efeito de separação de fases da mistura, semelhante à mistura de água e óleo. Este fato seria indesejado, pois o objetivo de acrescentar areia fina é apenas de preencher os vazios, melhorando conseqüentemente a textura, absorção de água e resistência à compressão.

\subsubsection{Dosagem do concreto}

Devido à dificuldade de obter referências técnicas para dosagem de concreto com abatimento nulo, foram necessárias várias séries de moldagem de corpos-de-prova cilíndricos. Com a falta de agregados reciclados destinados à produção de blocos vazados de concreto, e mediante a falta de correlação de resistência à compressão entre corpos-de-prova cilíndricos de $10 \times 20 \mathrm{~cm}$ e a geometria dos blocos vazados de concreto de 39x14x19cm, moldaram-se algumas séries de traços em corpos-de-prova cilíndricos.

Com o controle tecnológico de laboratório, as amostras que representassem as maiores resistências à compressão, aos 28 dias de idade, foram destinadas à fabricação dos blocos correspondente à respectiva série. Como as normas vigentes de blocos de concreto não estipulam uma idade para determinar a resistência característica à compressão, cada série de bloco foi ensaiada somente aos 28 dias de idade. Caso a série de bloco não resultasse na resistência mínima 
estrutural de 4,5MPa em relação à área bruta, segundo a NBR 6136/94, realizavamse novas séries de traços. Ressalta-se que, depois de determinadas as resistências características à compressão, retiravam-se fragmentos de cada série de traço para utilizar como amostra destinada à determinação da absorção, uma vez que a mesma norma admite que a absorção de água seja inferior a 10\%. A seguir, apresenta-se na Figura 4.8 o fluxograma para determinar a escolha do traço.

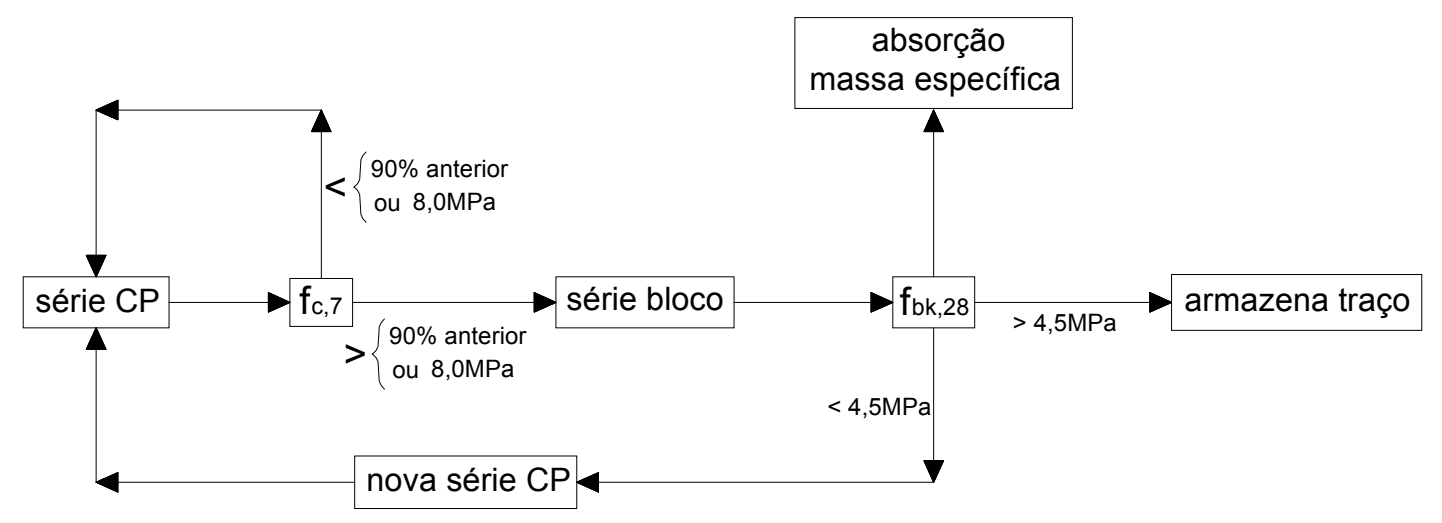

Figura 4.8 - Fluxograma da escolha do traço para a confecção dos

blocos de concreto destinados aos painéis de alvenaria

\subsubsection{Resistência à compressão $\underline{\text { dos }} \underline{\text { corpos-de-prova cilíndricos }}$}

Devido à alta porosidade do concreto no estado fresco, decidiu-se modificar a energia de vibração aplicada durante a moldagem dos corpos-de-prova, procurando simular, com soquetes de diferentes diâmetros, o adensamento do concreto ao das prensas hidro-pneumáticas das fábricas de blocos de concreto. Esta contrariedade às exigências da NBR 5738/94 - Moldagem e cura de corpos-de-prova cilíndricos ou prismáticos, ocorreu pela ausência de relações entre consistências rijas e energia de compactação (necessária para obter o menor índice de vazios) através da combinação da energia de vibração e compactação mecânica. A Tabela 4.2 expõe o estudo de traços para bloco de concreto, no qual cada traço está caracterizado pelo valor médio de 3 corpos-de-prova cilíndricos $10 \times 20 \mathrm{~cm}$. 
Tabela 4.2 - Estudo de traço para bloco de concreto

\begin{tabular}{|c|c|c|c|c|c|c|c|c|}
\hline série & traço (massa) & $\mathrm{F}(\mathrm{kN})$ & $\begin{array}{c}\mathrm{f}_{\mathrm{c} 7} \\
(\mathrm{MPa})\end{array}$ & \multicolumn{4}{|c|}{ relação entre agregados (\%) } & adensamento \\
\hline T1 & $1: 3,8: 3,1: 0,58$ & 67,6 & 8,61 & 0 & 100 & 30 & 70 & $\mathrm{~V}$ \\
\hline TM1 & $1: 3,8: 3,1: 0,58$ & 31,6 & 4,03 & 0 & 100 & 50 & 50 & V \\
\hline TM2 & $1: 3,8: 3,1: 0,58$ & 21,7 & 2,76 & 0 & 100 & 100 & 0 & V \\
\hline TM3 & $1: 5,24: 3,89: 0,86$ & 40,9 & 5,21 & 0 & 100 & 45 & 55 & V \\
\hline TM4 & $1: 5,24: 3,89: 0,86$ & 70,6 & 8,99 & 0 & 100 & 45 & 55 & 2C: V \\
\hline TM5 & 1: $5,24: 3,89: 0,86$ & 76,5 & 9,74 & 0 & 100 & 45 & 55 & $2 C: V+15 G$ \\
\hline TM6 & 1: $5,24: 3,89: 0,97$ & 73,2 & 9,32 & 0 & 100 & 100 & 0 & $4 C: V+30 G$ \\
\hline TM7 & 1: $5,24: 3,89: 0,97$ & 74,3 & 9,45 & 15 & 85 & 45 & 55 & $4 C: V+30 G$ \\
\hline TM8 & $1: 4,78: 4,36: 0,94$ & 73,4 & 9,34 & 15 & 85 & 45 & 55 & $4 C: V+30 G$ \\
\hline TM9 & $1: 5,34: 3,77: 0,94$ & 88,4 & 11,25 & 15 & 85 & 45 & 55 & $2 C: 30 G$ \\
\hline TM10 & $1: 2,84: 2,16: 0,52$ & 68,9 & 8,77 & 15 & 85 & 45 & 55 & $2 C: V+30 G$ \\
\hline TM11 & $1: 2,84: 2,16: 0,70$ & 228,9 & 29,14 & 15 & 85 & 45 & 55 & V \\
\hline TM12 & $1: 3,98: 3,02: 0,72$ & 73,4 & 9,35 & 15 & 85 & 45 & 55 & $2 C: V+30 G$ \\
\hline TMR1 & $1: 5,24: 3,89: 1,37$ & 49,3 & 6,28 & & 100 & 45 & 55 & $4 C: V+30 G$ \\
\hline TMR2 & $1: 5,24: 3,89: 1,71$ & 39,4 & 5,02 & & 100 & 45 & 55 & 4C: $30 \mathrm{G}$ \\
\hline TMR3 & $1: 5,24: 3,89: 1,71$ & 27,1 & 3,45 & & 100 & 45 & 55 & $2 C: V+15 G C$ \\
\hline TMR4 & $1: 5,24: 3,89: 1,71$ & 24,5 & 3,11 & & 100 & 45 & 55 & $2 C: V+5 G C$ \\
\hline TMR5 & $1: 5,34: 3,77: 1,66$ & 53,9 & 6,86 & & 100 & 45 & 55 & V \\
\hline TMR6 & $1: 4,59: 3,41: 1,38$ & 70,5 & 8,98 & & 100 & 45 & 55 & V \\
\hline TMR7 & $1: 4,02: 2,98: 0,98$ & 30,4 & 3,87 & & 100 & 45 & 55 & $2 C: V+30 G$ \\
\hline
\end{tabular}

Onde:

TM: traço modificado com agregado miúdo natural;

TMR: traço modificado com agregado miúdo reciclado;

$\mathrm{C}: \quad \mathrm{n}^{\circ}$ de camadas compactadas;

V: vibrado;

G: $\quad \mathrm{n}^{\mathrm{o}}$ de golpes com soquete metálico de $16 \mathrm{~mm}$ de diâmetro;

GC: $\quad n^{\circ}$ de golpes com soquete de concreto de $95 \mathrm{~mm}$ de diâmetro.

O traço piloto T1 e suas modificações TM1 e TM2, baseiam-se no estudo realizado por Pimienta \& Delmotte (1998), em que se variaram apenas as proporções entre os agregados reciclados. Os demais traços foram baseados na metodologia proposta pela ACI 211.3-75/92 e pela A.B.C.P., mencionados no capítulo 2, pela qual variaram-se as proporções entre os agregados, tipo de adensamento, teor de cimento e quantidade de água. Ressalta-se que o traço TM11 resultou na maior resistência à compressão, mas não foi selecionado devido seu elevado consumo de cimento.

Quanto aos traços produzidos apenas com agregados reciclados, a substituição dos agregados resultou na brusca redução de resistência. Supõe-se que 
este fato tenha ocorrido devido a alteração da relação água/cimento, da energia de vibração, e do proporcionamento inadequado entre os agregados reciclados. Desta forma, é possível que, mesmo possuindo menor resistência, os mesmos traços de TMR1 a TMR7poderiam ser utilizados na produção de blocos sem função estrutural.

\subsubsection{Fabricação $\underline{\text { de blocos piloto de concreto }}$}

Após obter as maiores resistências à compressão, de cada série, em corpos-de-prova de concreto com abatimento nulo, fabricaram-se os respectivos blocos piloto de concreto em pequena quantidade na Itaúna Blocos, para que fosse analisada a resistência característica à compressão, absorção, área líquida e massa específica. A seguir, apresenta-se na Tabela 4.3, a resistência característica à compressão dos blocos (f bk) conforme MB-116/91: Blocos vazados de concreto simples para alvenaria: Determinação da resistência à compressão, e NBR 6136/94: Bloco vazado de concreto simples para alvenaria estrutural, sendo que a resistência média de cada bloco $\left(\mathrm{f}_{\mathrm{b}}\right)$ foi obtida pela área bruta de seu respectivo bloco.

Devido à proximidade da resistência exigida por norma, como as obtidas e pelo fato de que o principal trabalho é analisar o comportamento dos blocos com características mínimas para função estrutural, acrescentaram-se mais 2 dosagens modificadas a partir do TM8, com acréscimo de $10 \%$ e $20 \%$ de cimento, ou seja:

$$
\begin{aligned}
& \mathrm{TM}_{\mathrm{m} 1}=1+10 \%: 4,78: 4,36: 0,94=1: 4,35: 3,96: 0,96 \\
& \mathrm{TM}_{\mathrm{m} 2}=1+20 \%: 4,78: 4,36: 0,94=1: 3,98: 3,63: 0,89
\end{aligned}
$$

Tabela 4.3 - Determinação da resistência característica à compressão dos blocos

\begin{tabular}{c|c||c|c|c|r}
\hline \hline traço & idade (dias) & $\mathrm{F}_{\mathrm{m}}(\mathrm{kN})$ & $\mathrm{fb}(\mathrm{MPa})$ & $\mathrm{fbk}(\mathrm{MPa})$ & $\mathrm{CV}(\%)$ \\
\hline \hline \multirow{2}{*}{$\mathrm{T} 1$} & 7 & 126,57 & 2,29 & 1,25 & 28,8 \\
& 14 & 179,57 & 3,25 & $2,75(2,20)$ & 4,8 \\
& 28 & 272,03 & 4,93 & $4,00(3,20)$ & 10,1 \\
\hline \multirow{2}{*}{$\mathrm{TM} 8$} & 7 & 198,60 & 3,67 & 3,15 & 4,5 \\
& 28 & 242,75 & 4,52 & $3,75(1,19)$ & 9,3 \\
\hline TM9 & 28 & 245,09 & 4,53 & 3,75 & 16,2 \\
\hline \multirow{2}{*}{ TM8 } & 7 & 324,00 & 6,02 & 5,00 & 9,0 \\
& 28 & 312,55 & 5,81 & $4,70(0,94)$ & 10,4 \\
\hline TM8 & 28 & 315,42 & 5,86 & 4,80 & 11,3 \\
\hline \multirow{2}{*}{ TMR6 } & 7 & 65,32 & 1,21 & 0,95 & 17,4 \\
& 28 & 71,60 & 1,33 & $1,05(1,10)$ & 21,8 \\
\hline \hline
\end{tabular}


Todos os blocos foram ensaiados à compressão com a mesma prensa, com controle de carregamento constante. No entanto, devido à manutenção deste equipamento, necessitou-se utilizar, aos 7 dias de idade, outra prensa, sendo que a única disponível era com carregamento de abertura de válvula manual, impedindo a constância do carregamento de 2,73kN/s, conforme estabelecido pelas normas vigentes de $5 \mathrm{~N} / \mathrm{cm}^{2} / \mathrm{s}$. Desta forma, o carregamento manual possibilitou o acréscimo da velocidade de aplicação de carga, resultando no aumento de resistência. Portanto, considera-se que a resistência característica à compressão aos 7 dias de idade é inferior a 4,70MPa.

Devido a diferentes quantidades de blocos produzidos, a idade determinada para ser realizado o ensaio de resistência à compressão foi imposta de modo a obter uma amostra significativa aos 28 dias de idade. A presença de mais de 3 blocos possibilitou determinar a resistência à compressão aos 7 e aos 14 dias de idade, para analisar o desempenho mecânico com a idade.

Outro fato relevante a ser comentado é a resistência à compressão do traço TMR6. A estimativa do estudo do bloco de concreto com agregados totalmente reciclados, sem função estrutural, foi calamitosa, conforme mostra a Tabela 4.3, cuja resistência média à compressão deste tipo de bloco é inferior à mínima de $2,5 \mathrm{MPa}$ para bloco sem função estrutural, segundo a NBR 7184/82.

A seguir encontram-se na Tabela 4.4 as características dos traços que superaram a resistência mínima e o traço com agregados totalmente reciclados.

Tabela 4.4 - Características dos traços de bloco de concreto

\begin{tabular}{c||c|c|c|c}
\hline \hline série & Ceórico $\left(\mathrm{kg} / \mathrm{m}^{3}\right)$ & teor água $(\%)$ & teor argamassa (\%) & relação cimento/agregado \\
\hline \hline TM8 ${ }_{\mathrm{m} 1}$ & 212,66 & 10,31 & 57,47 & $1: 8,31$ \\
TM8 ${ }_{\mathrm{m} 2}$ & 230,20 & 10,34 & 57,84 & $1: 7,61$ \\
\hline TMR6 & 198,30 & 15,33 & 62,11 & $1: 8,00$ \\
\hline \hline
\end{tabular}

Nota-se na Tabela 4.4 que o consumo de cimento foi o principal fator que diferenciou os traços $\mathrm{TM} 8_{\mathrm{m} 1}$ e $\mathrm{TM} 8_{\mathrm{m} 2}$, e que determinou a menor resistência à compressão do traço TMR6. 


\subsubsection{Absorção e área líquida}

$\mathrm{Na}$ Tabela 4.5, apresentam-se os resultados das características dos blocos quanto à absorção e massa específica, conforme MB-3459/91 e NBR 7186/82, cujos valores máximos, para função não estrutural, de absorção média e individual, devem ser inferiores a $10 \%$ e $15 \%$ respectivamente.

Tabela 4.5 - Determinação da absorção e massa específica

\begin{tabular}{c||cc|cc}
\hline \hline \multicolumn{1}{c||}{ série } & \multicolumn{2}{c|}{ absorção } & \multicolumn{2}{c}{ massa específica } \\
& média (\%) & CV $(\%)$ & média $\left(\mathrm{g} / \mathrm{cm}^{3}\right)$ & CV $(\%)$ \\
\hline \hline T1 & 10,77 & 0,04 & 1,90 & 1,47 \\
TM8 & 10,47 & 0,13 & 1,90 & 0,01 \\
TM8 m1 & 8,71 & 0 & 1,97 & 0 \\
TM8 m2 & 9,17 & 0,98 & 2,01 & 0,17 \\
\hline TMR6 & 16,18 & 0,02 & 1,70 & 0,01 \\
\hline \hline
\end{tabular}

$\mathrm{Na}$ Tabela 4.5, nota-se que a série de bloco com agregados totalmente reciclados, resultaram em absorção superior à taxa permitida pela MB-3459/91. É provável que, ao utilizar maiores consumos de cimento, seja possível obter blocos com resistência superiores a 2,5MPa e com absorção média inferior a $10 \%$, tornandose viável à produção de blocos de concreto de vedação. Analisando as absorções médias dos traços $\mathrm{TM} 8_{\mathrm{m} 1}$ e TM8 $8_{\mathrm{m} 2}$, verifica-se que ambos possuem baixa absorção, além de demonstrarem maior massa específica. Ressalta-se que a absorção é importante não apenas à estanqueidade a água, mas também ao processo de carbonatação.

Desta forma, concluiu-se que os blocos que obtiveram um bom desempenho quanto à resistência característica, aparência superficial e absorção foram os traços TM8 modificados. No entanto, o traço adotado para a produção dos blocos foi o TM8 $\mathrm{m} 1$, devido ao menor consumo de cimento, resistência característica superior e absorção inferior à máxima proposta pela NBR 6136/94.

\subsubsection{Argamassa}

Com o objetivo de verificar a possibilidade de utilizar a fração miúda do agregado reciclado, passante pela peneira de abertura $\# 2,4 \mathrm{~mm}$, foi realizado um estudo de traço de argamassa utilizando agregados naturais e reciclados, comparando-os quanto à resistência à compressão e tração por compressão diametral. 


\subsubsection{Características dos materiais utilizados para o estudo $\underline{\text { de }} \underline{\text { argamassa }}$}

A massa específica no frasco de Chapman e a massa unitária em estado solto, dos materiais utilizados para a produção de argamassa, foram determinadas conforme a NBR 9776/87 e a NBR 7251/82, respectivamente, cujos resultados apresentam-se na Tabela 4.6. Ressalta-se que, a cal CH III, hidratada, comum com carbonatos, e o cimento CP IIE-32, utilizados para o estudo, foram escolhidos pelo fato de serem os tipos mais comercializados e de maior presença no mercado.

Tabela 4.6-Massas específica e unitária dos componentes da argamassa

\begin{tabular}{c||cc||c|c|c}
\hline \hline \multirow{2}{*}{ argamassa } & \multicolumn{2}{|c||}{ material } & procedência & $\gamma_{\mathrm{s}}\left(\mathrm{kg} / \mathrm{dm}^{3}\right)$ & $\delta\left(\mathrm{kg} / \mathrm{dm}^{3}\right)$ \\
\hline \hline \multirow{3}{*}{ natural } & cimento & CP IIE -32 & Itaú & 3,13 & 1,18 \\
& cal & CH III & Itaú & 2,65 & 0,72 \\
& agregado miúdo & areia & Rio Mogi-Guaçu & 2,60 & 1,59 \\
\hline \hline \multirow{2}{*}{ reciclada } & cimento & CP IIE -32 & Itaú & 3,13 & 1,18 \\
& cal & CH III & Itaú & 2,65 & 0,72 \\
& agregado miúdo & reciclado & Ribeirão Preto & 2,50 & 1,36 \\
\hline \hline
\end{tabular}

A análise dos agregados miúdos foi obtida depois de retirada uma amostra do lote segundo a NBR 9941/87, seguida do quarteamento até obter uma quantidade suficiente para que fosse possível caracterizá-los, como prescreve a NBR 7216/82.

$\mathrm{Na}$ Figura 4.9, apresenta-se a curva granulométrica dos agregados miúdos destinados ao estudo de produção de argamassa. Ao analisar a graduação dos materiais, observa-se que a amostra do agregado reciclado $(\mathrm{R})$ possui uma melhor distribuição dimensional comparada ao agregado natural (N). Com isso, esperava-se que pudesse haver uma melhor compacidade, mesmo que a resistência das partículas dos agregados reciclada fosse inferior e de forma lamelar.

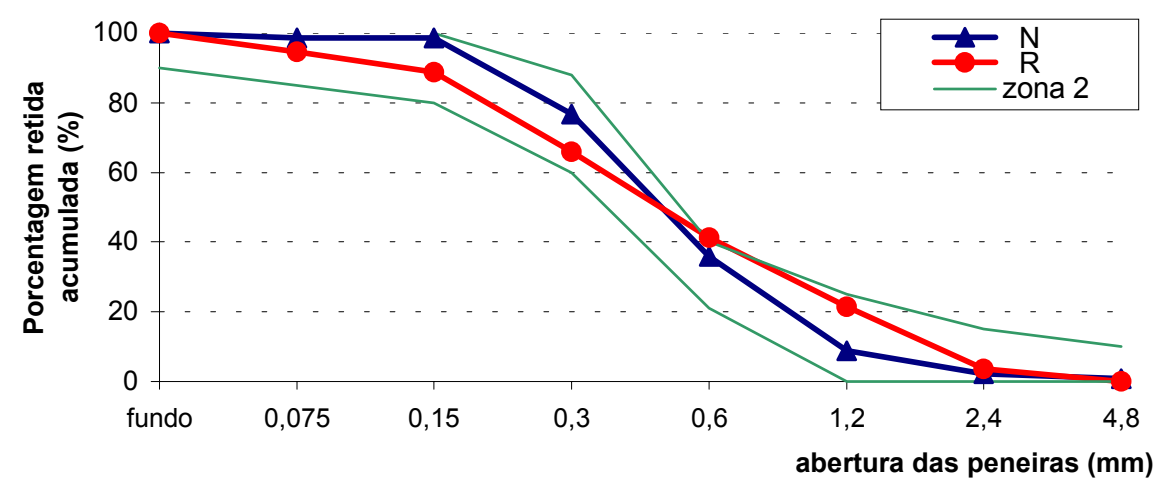

Figura 4.9 - Curva granulométrica dos agregados miúdos 
Para caracterizar os agregados miúdos quanto à variação do volume devido ao contato com a água, fez-se o ensaio de inchamento dos agregados com dimensão máxima característica de $2,4 \mathrm{~mm}$, segundo a metodologia proposta pela MB-215/54. A Figura 4.10 apresenta as curvas de inchamento dos agregados naturais e reciclados. Esta metodologia baseia-se na adição de água feita sucessivamente de modo a obter uma mistura homogênea entre a amostra de agregado e os teores de umidade de $0,5 \%$ a $12 \%$, determinando-se a massa unitária para cada teor de umidade. A relação entre os volumes úmido e seco para mesma massa é expressa pela Equação 4.2 .

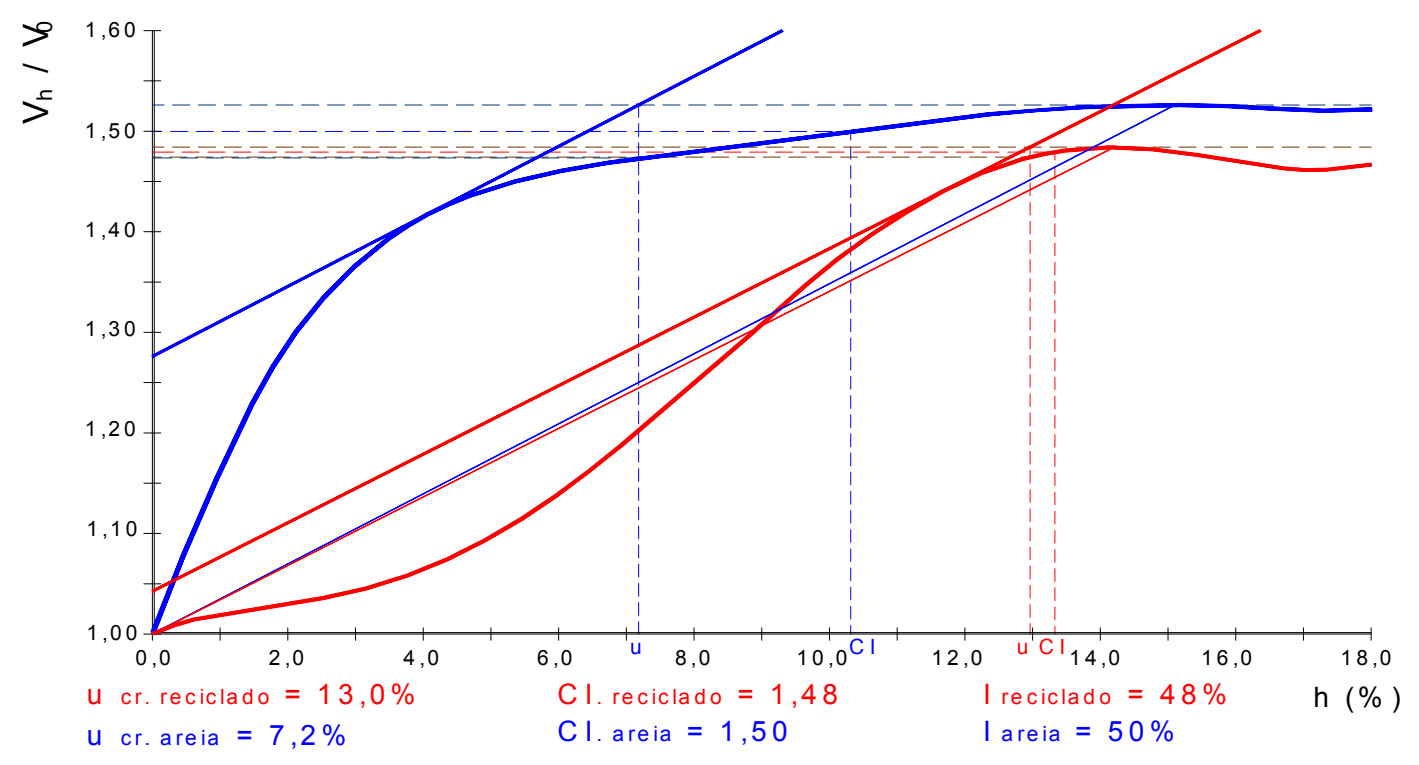

Figura 4.10 - Curva de inchamento dos agregados miúdos

$$
\frac{\mathrm{V}_{\mathrm{h}}}{\mathrm{V}_{0}}=\frac{\delta_{0}}{\delta_{\mathrm{h}}} \times \frac{(100+\mathrm{h})}{100}
$$

Onde:

$\mathrm{V}_{\mathrm{h}}$ : volume do agregado com $\mathrm{h} \%$ de umidade;

$\mathrm{V}_{0}$ : volume do agregado seco em estufa;

$\delta_{\mathrm{h}}$ : massa unitária do agregado com $\mathrm{h} \%$ de umidade;

$\delta_{0}$ : massa unitária do agregado seco em estufa;

$\mathrm{h}$ : teor de umidade do agregado (\%);

$\mathrm{u}_{\mathrm{cr}}$ : umidade crítica do agregado;

$\mathrm{CI}$ : coeficiente de inchamento do agregado $\left(\mathrm{V}_{\mathrm{h}} / \mathrm{V}_{0}\right)$;

I : inchamento do agregado (\%). 
Nota-se que houve um pequeno decréscimo de volume com umidade de 16\%. Uma hipótese seria o fato de, neste acréscimo de água, ocorrer um efeito de lubrificação entre as partículas finas do agregado miúdo e o filme de água.

Segundo BUENO \& VILAR (1996), a Teoria Adesiva do Atrito proposta por TERZAGUI menciona que "a superfície de contacto real entre dois corpos constitui apenas uma parcela da superfície aparente de contacto, dado que a um nível submicroscópico as superfícies dos materiais são efetivamente rugosas. O contacto se dá então apenas nas protuberâncias mais salientes”, conforme Figura 4.11.

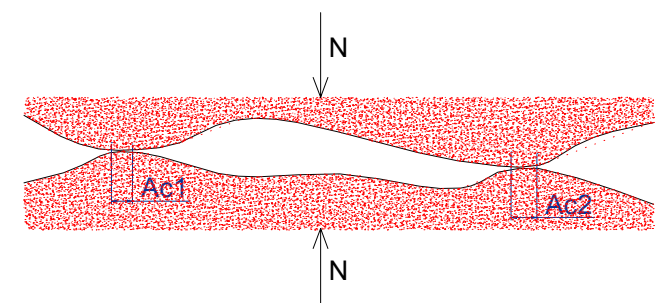

a)

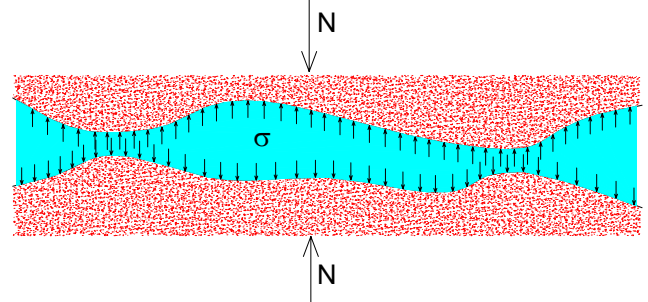

b)

Figura 4.11 - Contacto entre corpos sólidos

FONTE: BUENO \& VILAR, 1985

Dessa forma, pode-se concluir que a resistência por atrito depende da força normal, pois aumentando esta, a área real de contato (Ac) aumenta. No entanto, a tensão efetiva depende do índice de vazios, teor de umidade, ângulo de atrito, rugosidade e outros. Ao se aumentar o teor de umidade dos agregados, aumenta a quantidade de água presente na superfície de contato entre os agregados, até que a tensão superficial da partícula de água supere a força normal, resultando no deslocamento do sólido, e conseqüentemente, na perda de atrito entre os agregados.

\subsubsection{Proporcionamento dos materiais e características das argamassas}

O estudo foi baseado na escolha de 3 traços com diferentes consumos de cimento, conforme os requisitos da BS 5628 part 1 e 2 (1978) para argamassas, que estabelece a relação de 1:3 de aglomerantes/agregados. A Tabela 4.7 expõe os traços, em massa, da Tabela 2.10. 
Tabela 4.7 - Traço das argamassas

\begin{tabular}{|c|c|c|c|c|c|c|c|c|c|c|c|}
\hline \multicolumn{2}{|r|}{ tipo } & \multicolumn{4}{|c|}{ volume } & \multicolumn{3}{|c|}{$\begin{array}{c}\text { proporção } \\
\text { natural (massa) }\end{array}$} & \multicolumn{3}{|c|}{ reciclado (massa) } \\
\hline 1 & rico & 1 & : & 0,25 & $: 3,75$ & 1 & $: 0,15$ & $: 4,83$ & 1 & 0,15 & 4,32 \\
\hline II & médio & 1 & : & 0,50 & $: 4,50$ & 1 & $: \quad 0,31$ & : 5,80 & 1 & 0,31 & $: 5,19$ \\
\hline III & pobre & 1 & $\vdots$ & 1,00 & $: 6,00$ & 1 & $: \quad 0,61$ & $: 7,73$ & 1 & 0,61 & $: 6,92$ \\
\hline
\end{tabular}

As quantidades de água utilizada na preparação das argamassas, foram determinadas em função do índice de consistência ideal estabelecida previamente de $230 \pm 10 \mathrm{~mm}$. Os principais parâmetros das argamassas, apresentam-se na Tabela 4.8, obtidos segundo a NBR 13276/85 e NBR 13278/95. O consumo real de cimento foi determinado pela massa específica da argamassa no estado fresco, ou seja, pela relação entre massa e volume da argamassa, utilizando um recipiente cilíndrico de PVC com volume conhecido, onde se considera a presença de ar incorporado.

Tabela 4.8 - Características das argamassas

\begin{tabular}{|c|c|c|c|c|c|c|}
\hline agregado & tipo & $a / c$ & $\mathrm{IC}(\mathrm{mm})$ & $\mathrm{C}_{\text {teórico }}\left(\mathrm{kg} / \mathrm{m}^{3}\right)$ & $\mathrm{A}\left(\mathrm{g} / \mathrm{cm}^{3}\right)$ & $\mathrm{C}_{\text {real }}\left(\mathrm{kg} / \mathrm{m}^{3}\right)$ \\
\hline natural & I rico & $\overline{11,00}$ & 220 & 310 & 2,01 & 287 \\
\hline natural & II médio & 1,16 & 225 & 255 & 1,98 & 240 \\
\hline natural & III pobre & 1,56 & 230 & 197 & 1,98 & 182 \\
\hline reciclado & I rico & 1,23 & 233 & 300 & 1,99 & 297 \\
\hline reciclado & II médio & 1,50 & 239 & 249 & 1,96 & 244 \\
\hline reciclado & III pobre & 2,05 & 240 & 186 & 1,95 & 183 \\
\hline
\end{tabular}

Onde:

a/c: relação água/cimento;

IC: índice de consistência medido na mesa de espalhamento (NBR 13276/85);

$\mathrm{C}_{\text {teórico: }}$ consumo teórico de cimento da argamassa;

A: massa específica fresca da argamassa (NBR 13278/95);

$\mathrm{C}_{\text {real }}$ : consumo real de cimento da argamassa.

\subsubsection{Resistência à compressão $\underline{\text { e à tração por compressão diametral }}$}

Outro fator, que influencia na escolha da argamassa a ser utilizada na confecção de paredes e prismas de alvenaria, é a resistência à compressão e à tração indireta por compressão diametral. Os resultados dos corpos-de-prova cilíndricos $5 \times 10 \mathrm{~cm}$ da argamassa, contendo agregados natural $(\mathrm{N})$ e reciclado $(\mathrm{R})$, foram realizados segundo a NBR 13279/95 e NBR 7222/94, cujos desempenhos em relação à idade apresentam-se na Figura 4.12 e Figura 4.13. 


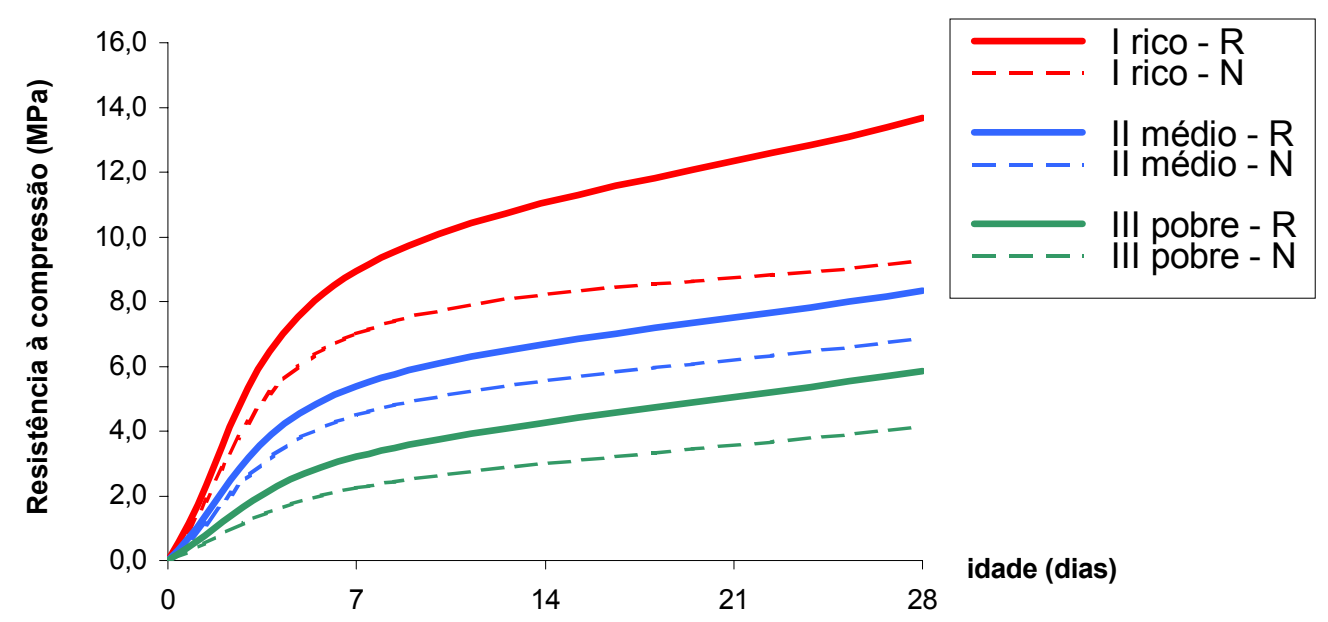

Figura 4.12 - Desempenho das argamassas ao ensaio de compressão

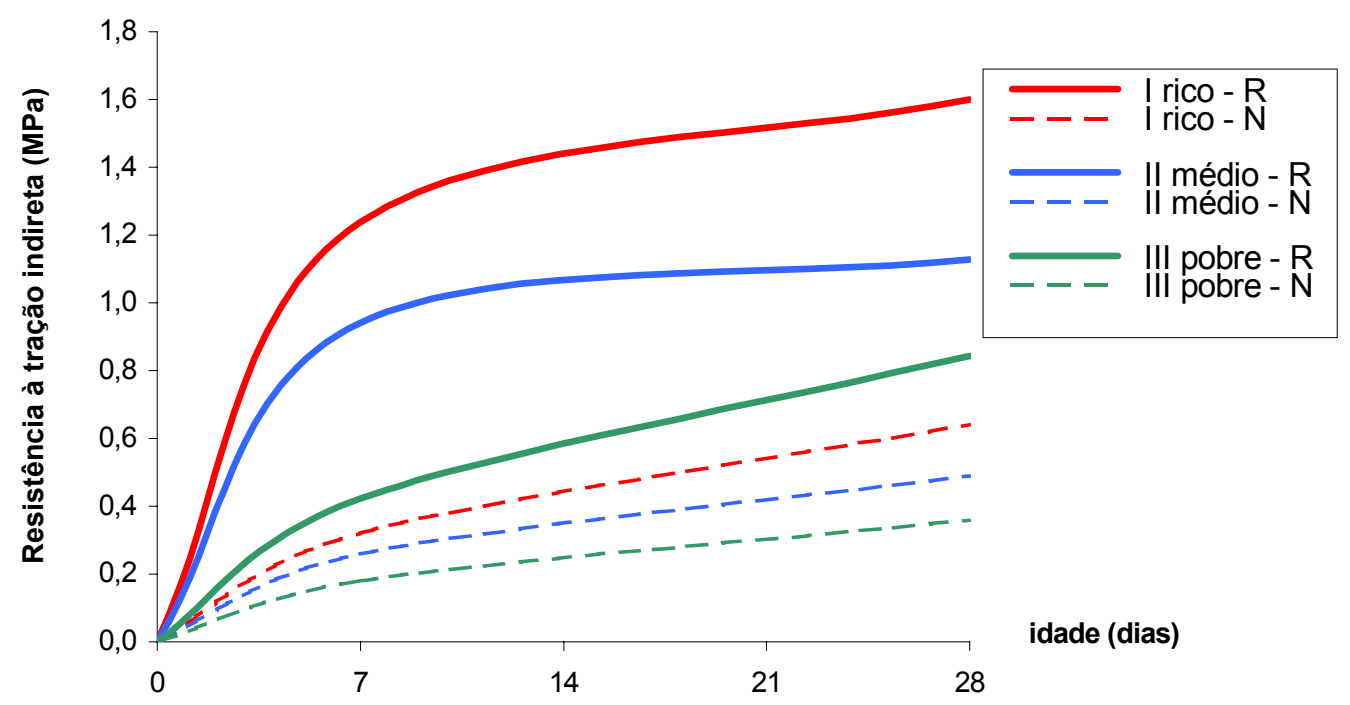

Figura 4.13 - Desempenho da argamassa ao ensaio de tração por compressão diametral

Conforme pode ser visto, a influência do agregado miúdo reciclado é significativa, pois, para o mesmo traço de argamassa, obteve-se resistência superior tanto no ensaio de resistência à compressão como no de tração por compressão diagonal.

Ao se compararem os resultados do gráfico exposto pela Figura 4.13, verifica-se que para o mesmo traço (em massa), a argamassa contendo agregado natural possui resistência à tração muito inferior às demais argamassas contendo agregado reciclado. Uma explicação para este fato seria o efeito de "cura interna", citado no capítulo 2 . 
Devido à boa resistência à compressão e tração por compressão diametral da argamassa mais fraca com agregado reciclado, e o baixo consumo de cimento, adotou-se o traço de argamassa mais adequado à resistência do bloco, que foi a do tipo III - pobre.

\subsection{Obtenção $\underline{\text { de }} \underline{\text { agregados }} \underline{\text { reciclados }}$}

Como o estudo de traço de concreto com abatimento nulo utilizou todo o estoque de agregados originários do lote de 1997, com dimensão máxima entre 4,8 e $9,5 \mathrm{~mm}$ e de 2,4 a 4,8 $\mathrm{mm}$, necessitou-se coletar mais agregados reciclados, para completar o volume estimado em $4 \mathrm{~m}^{3}$ necessário à confecção dos blocos.

Devido à grande quantidade de materiais impróprios como plásticos, metais, madeiras, borrachas e papéis, necessitou-se pré-selecionar o lote antes de iniciar o peneiramento. A Figura 4.14 apresenta a variedade da natureza e dimensões dos agregados reciclados de RCD, existentes no lote de 2001.

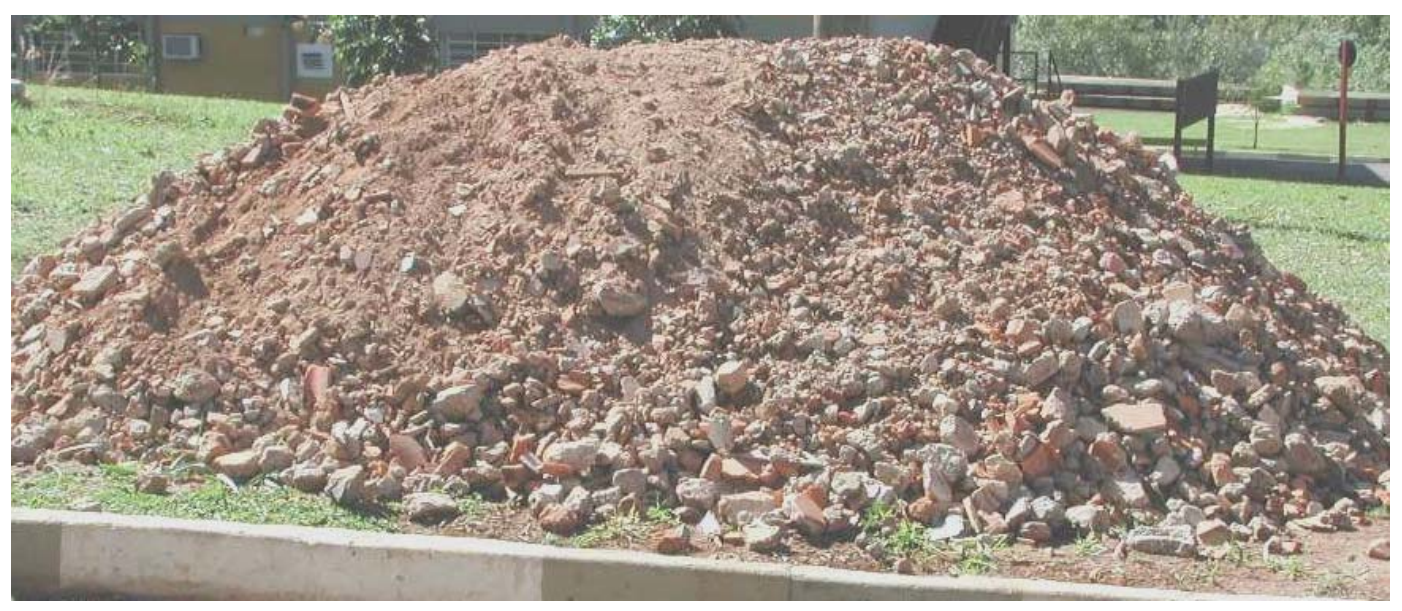

Figura 4.14 - Aspecto do lote recebido em setembro de 2001

Apenas para análise comparativa entre diferentes lotes, a Figura 4.15 apresenta as curvas granulométricas das amostras retiradas dos lotes de 1997 e 2001. 


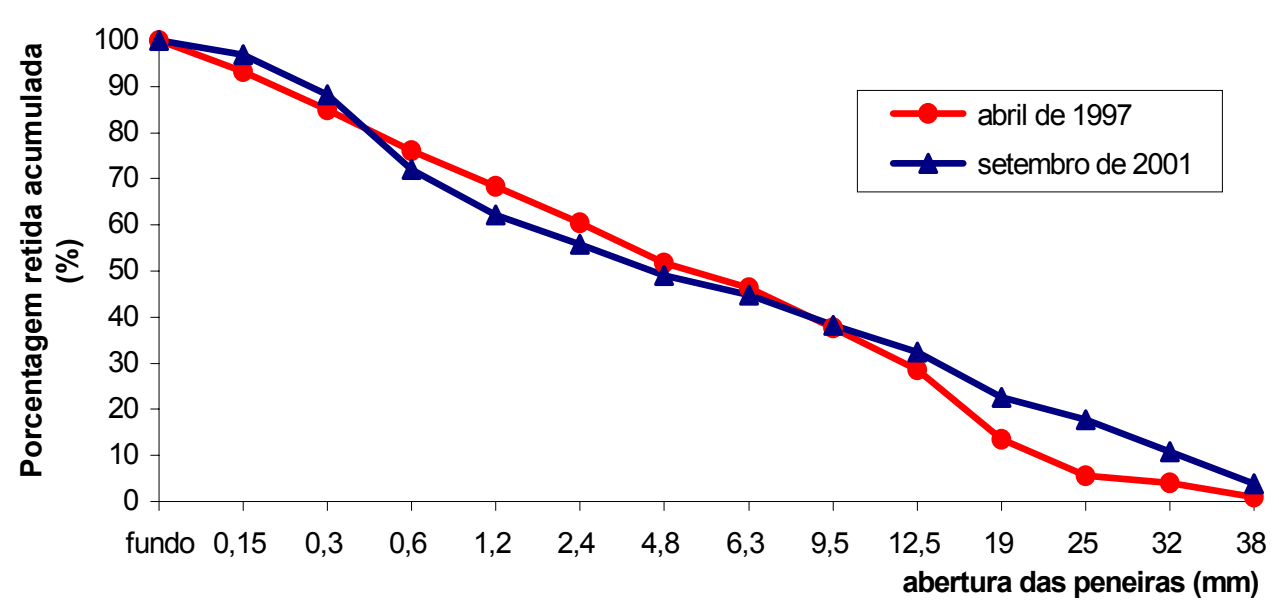

Figura 4.15 - Curvas granulométricas das amostras de agregados reciclados de $R C D$

Conforme pode ser analisado, a composição granulométrica do lote de 2001 apresenta-se mais graduada quando comparada ao lote anterior, porém nota-se que o lote de 1997 apresenta uma falta de agregados compreendidos entre as frações de 25 a $38 \mathrm{~mm}$. Outro fato que pode ser observado é que $25 \%$ da amostra de 2001 estão presentes entre as peneiras de abertura de $12,5 \mathrm{~mm}$ e $38 \mathrm{~mm}$, e que $50 \%$ de ambas as amostras são compostas por agregados passantes pela peneira $4,8 \mathrm{~mm}$ de abertura de malha. Da mesma forma, percebe-se que 38\% da amostra compõe a fração graúda retida pela peneira de abertura $9,5 \mathrm{~mm}$.

Para separar as frações necessárias, foi realizado o processo de peneiramento manual, utilizando peneiras com aberturas malha de $\# 2,4 \mathrm{~mm}, \# 4,8 \mathrm{~mm}$ e $\# 9,5 \mathrm{~mm}$ (Figura 4.16).

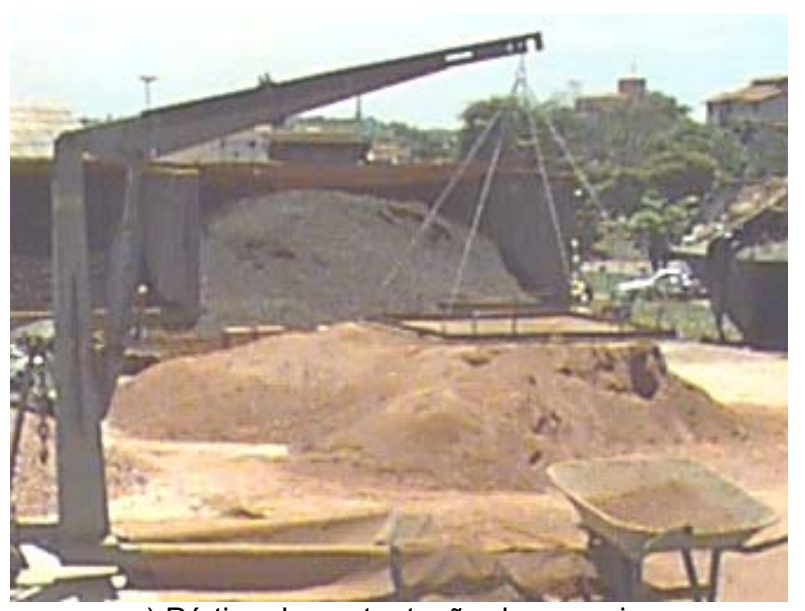

a) Pórtico de sustentação das peneiras

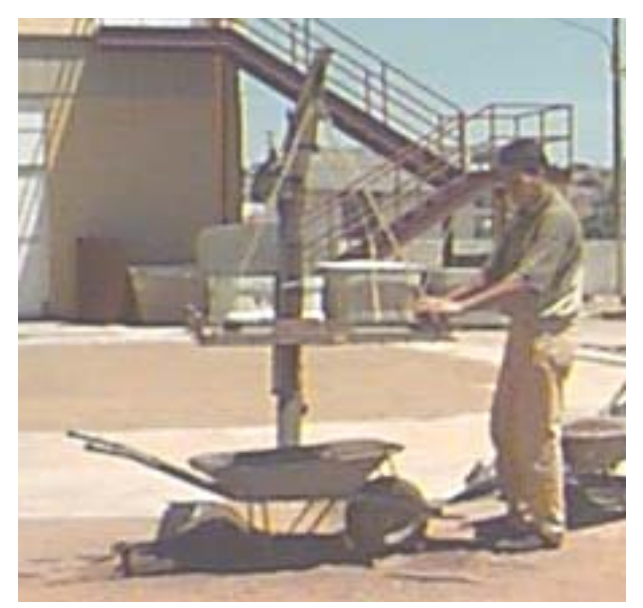

b) Peneiramento manual

Figura 4.16 - Processo de peneiramento dos agregados reciclados 
Após o termino do peneiramento, verificou-se que a quantidade de agregados de RCD com as frações a serem utilizadas era inferior ao volume estimado. Para otimizar o lote e completar a quantidade de agregados, necessitou-se re-britar a fração graúda retida pela peneira de abertura $12,5 \mathrm{~mm}$, no britador de mandíbula pertencente ao Depto. de Geotecnia da Escola de Engenharia de São Carlos. A Figura 4.17 apresenta o processo de re-britagem dos agregados de RCD.

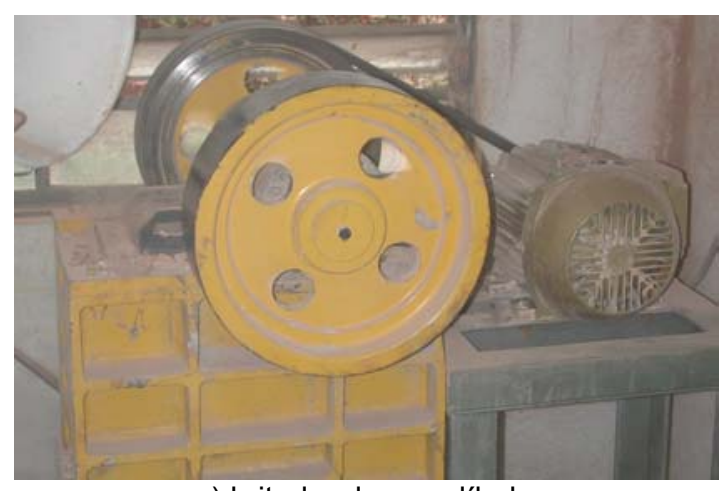

a) britador de mandíbula

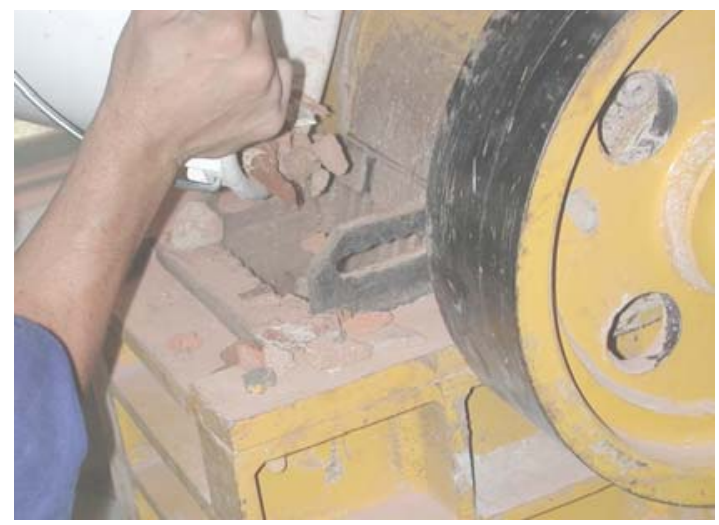

c) despejo do material a ser britado

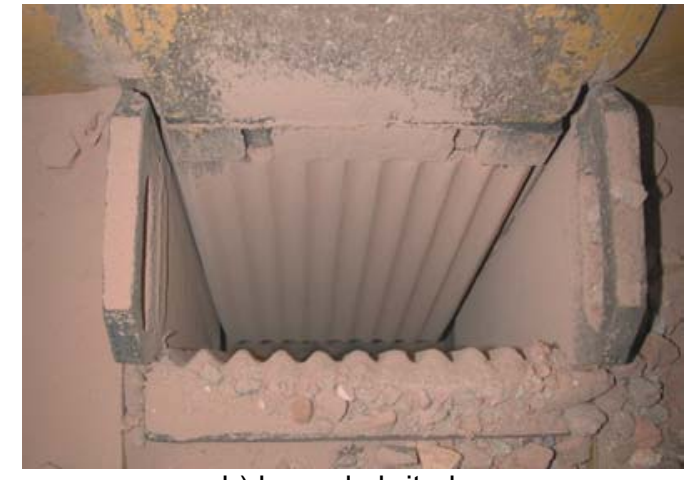

b) boca do britador

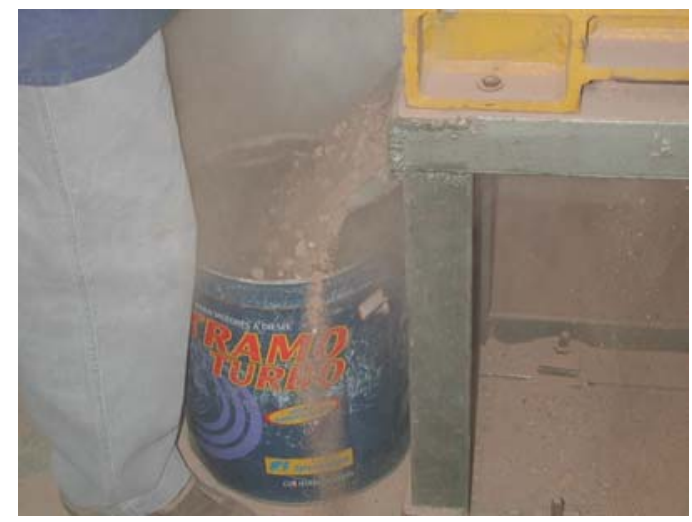

d) saída do material re-britado

Figura 4.17 - Processo de re-britagem de entulho

\subsubsection{Análise dos agregados reciclados de RCD}

Com o novo estoque de agregados, necessitou-se analisar a distribuição granulométrica das frações dos novos agregados reciclados de RCD, para determinar se haveria a necessidade de alterar a composição entre os agregados destinados à produção dos blocos de concreto. Ao se compararem as curvas granulométricas das frações de agregados reciclados do lote de 1997 e 2001 (Figura 4.18), verificou-se que a única alteração de granulometria foi referente apenas aos agregados reciclados com dimensão máxima de 2,4mm. 


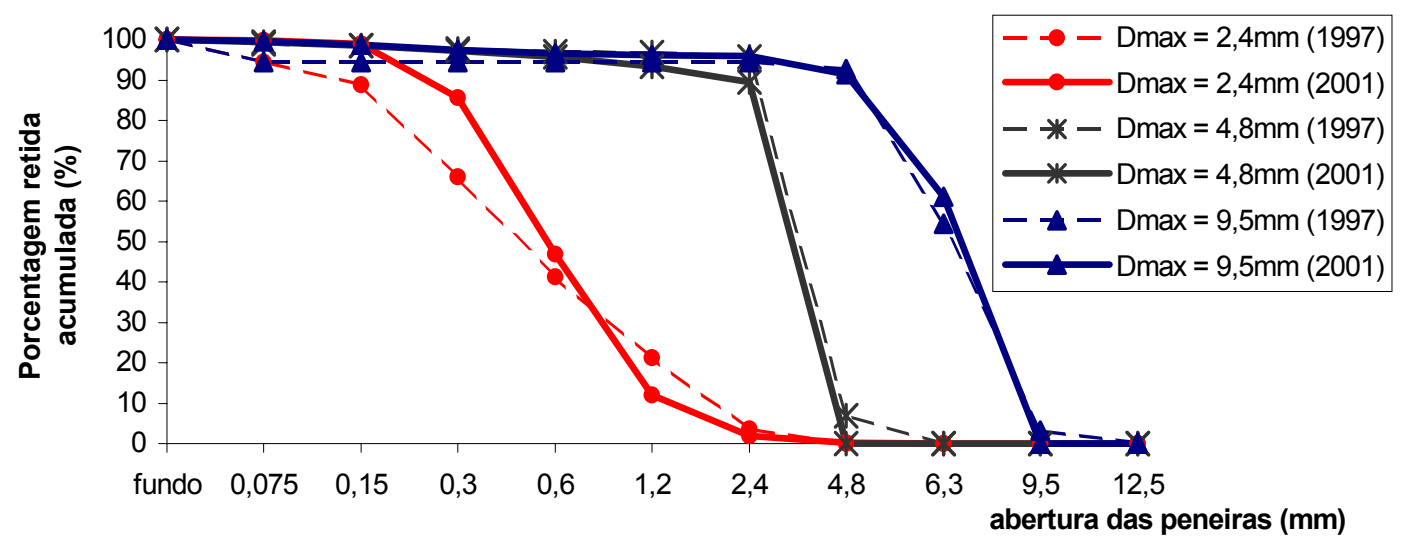

Figura 4.18 - Comparação das curvas granulométricas dos agregados reciclados utilizados à fabricação dos blocos de concreto

Entretanto, as análises das distribuições granulométricas individuais dos agregados não permitem determinar possíveis descontinuidades. Desta forma, é indispensável traçar a curva granulométrica composta pelos agregados naturais e reciclados, para que seja possível analisar o coeficiente de não uniformidade $\left(C_{u}\right)$ dos agregados destinados à produção dos blocos. Este importante parâmetro indica o quão desuniforme está a curva granulométrica, em função da inclinação de uma reta secante, representando assim a existência de espaços vazios não preenchidos por grãos menores (BUENO \& VILAR, 1995). A Figura 4.19, exibe a curva granulométrica, composta por todos os agregados naturais e reciclados, do traço adotado $\mathrm{TM} 8_{\mathrm{m} 1}$, que será utilizado para determinar $\mathrm{o}$ coeficiente de não uniformidade pela Equação 4.3 .

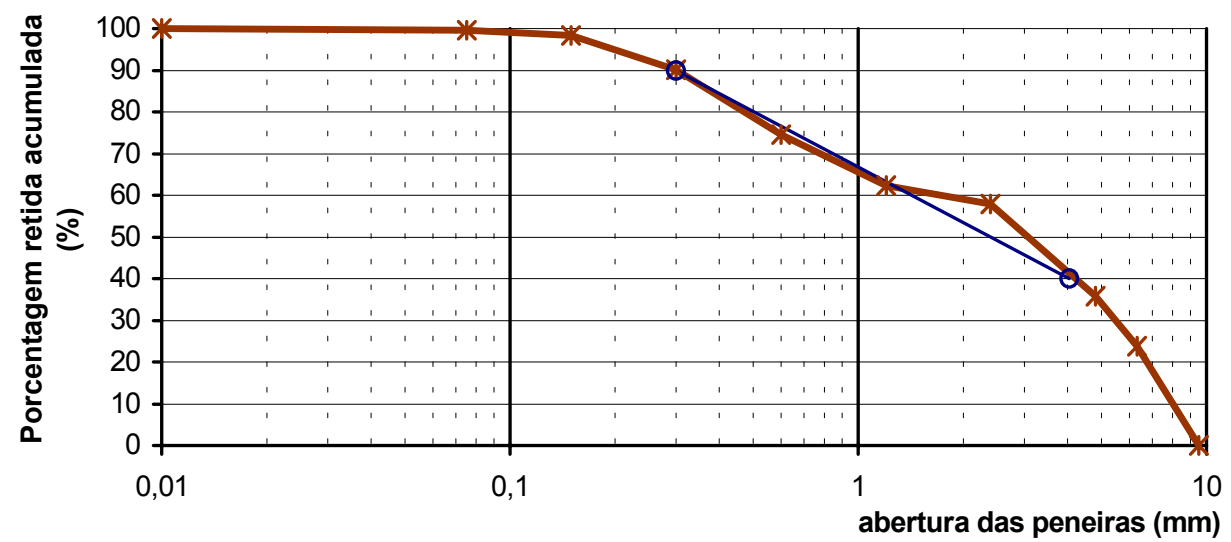

Figura 4.19 - Curva granulométrica composta dos agregados destinados à fabricação de blocos de concreto 


$$
C_{u}=\frac{D_{\text {max }, 60 \%_{\_} p a s}}{D_{\text {max }, 10 \%_{-} p a s}}
$$

Onde:

$\mathrm{D}_{\text {max, } \mathrm{x} \% \text { pas }}$ : diâmetro do agregado, em que $\mathrm{x} \%$ da distribuição granulométrica encontra-se menor que ela;

Segundo Bortoluzzo (2000), o coeficiente de não uniformidade da amostra dos agregados são definidos pela Tabela 4.9.

Tabela 4.9 - Coeficiente de não uniformidade

\begin{tabular}{c|c|c|}
\hline \hline muito uniforme & uniformidade média & desuniforme \\
\hline \hline $\mathrm{C}_{\mathrm{u}}<5$ & $5<\mathrm{C}_{\mathrm{u}}<15$ & $\mathrm{C}_{\mathrm{u}}>15$ \\
\hline \hline
\end{tabular}

Desta forma, conclui-se que o coeficiente de não uniformidade igual a 13,3, apresenta uniformidade média, isto é, existe uma carência de determinada fração de agregados, possivelmente com dimensão máxima de 1,2mm.

Contudo, a distribuição granulométrica não deve ser a única forma de analisar a composição do entulho, devido a possibilidade de sua natureza interferir na resistência do agregado reciclado. Segundo FonsECA (1999), os RCD no início de uma obra, os resíduos são constituídos predominantemente por madeira, concreto e barras de aço, enquanto que em outras fases da obra, destacam-se os materiais cerâmicos, argamassas, papéis e outros. Sendo assim, a utilização de agregados reciclados no canteiro de obra, sem haver um estudo da composição granulométrica, pode proporcionar sérias patologias como baixa aderência das argamassas de revestimento e elevado consumo de cimento para correção.

A Figura 4.20 compara a natureza dos agregados, em massa, com os lotes recebidos da Usina de Reciclagem de Entulho de Ribeirão Preto de amostras em épocas distintas, com dimensão máxima igual a $9,5 \mathrm{~mm}$. Conforme pode ser visto, a variedade da natureza dos agregados não foi brusca. Entretanto, baixas porcentagens de cerâmica polida e outros materiais como madeira, plásticos e materiais ferrosos podem interferir em suas resistências de compressão e de aderência à pasta de cimento. Desta forma, análises químicas referentes à composição mineralógica 
podem ser de extrema importância para prevenir sérias patologias, como reações expansivas oriundas de reações álcali-agregado.

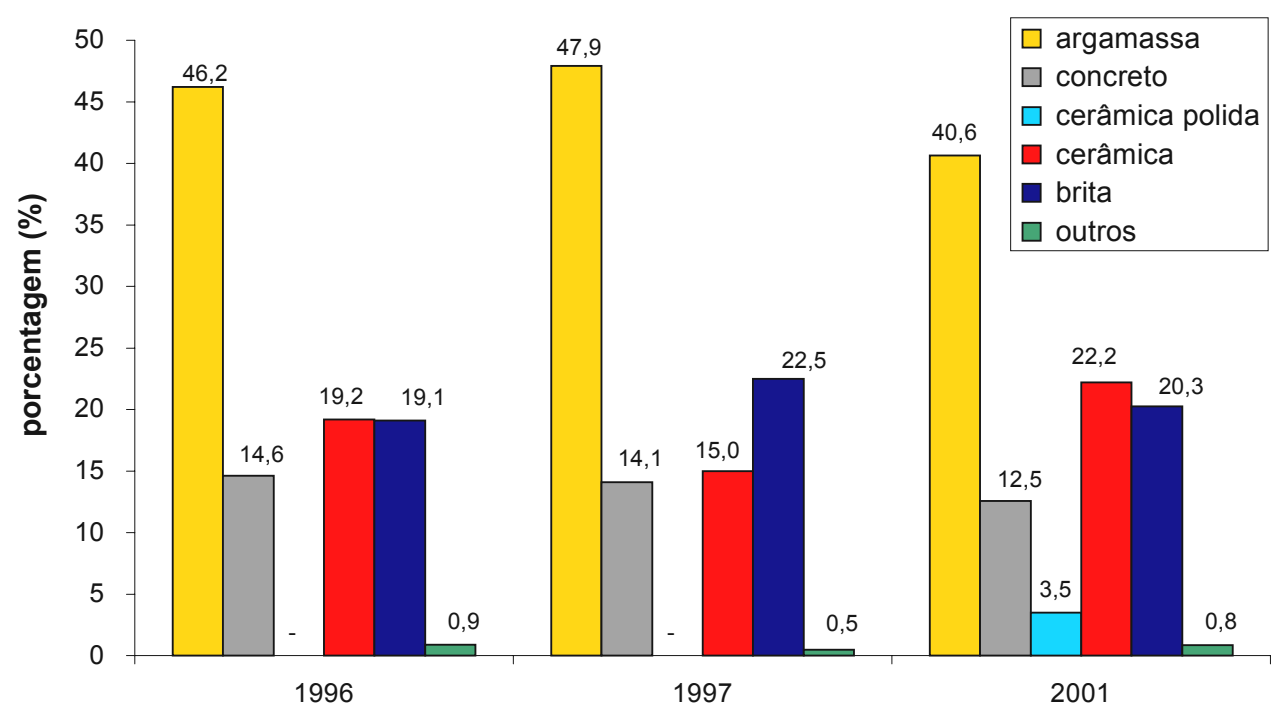

Figura 4.20 - Natureza da composição do agregado reciclado

Por mais que sejam diferentes os resultados, sempre haverá maior quantidade de argamassa no volume total do entulho. Segundo PINTO (1986) e LEVY (1997), a convencional e rudimentar técnica de assentamento de alvenaria e aplicação de revestimentos possibilitam grande contaminação durante o lançamento e sarrafeamento, queda de resistência e elevada permeabilidade das argamassas presentes nas lajes e nos painéis de alvenaria. Entretanto, verifica-se a redução do desperdício de argamassas, provavelmente pela eliminação de juntas verticais.

Em relação aos materiais cerâmicos, o aumento da porcentagem foi significativo. Com a distinção de cerâmica comum e com superfície polida, a porcentagem passou de $15 \%$ em 1997 a 22,2\% em 2001, e 25,7\% se considerar toda a porcentagem cerâmica. Este elevado aumento de desperdício pode ser oriundo de reformas, da grande procura por alvenaria sem função estrutural provenientes de olarias de baixa qualidade, ou pelo desconhecimento da técnica de execução de alvenaria cerâmica estrutural.

Dessa forma, como a única fração de agregados reciclados que sofreu alteração não está presente na constituição granulométrica, manteve-se o traço para a produção dos blocos de concreto com função estrutural. 


\section{$5 \underline{\text { FABRICACÃO}} \underline{\text { DE }} \underline{B L O C O S} \underline{E}$ PAREDES $\underline{\text { DE }} \underline{\text { ALVENARIA }}$}

Conforme mencionado no capítulo 4, a fábrica que se dispôs a produzir os blocos de concreto com função estrutural, possui pouco investimento em equipamentos, apresentando uma técnica rudimentar. Porém, por ser a única da região a possuir uma vibro-prensa mecânica, e pela qual foram realizados os blocos destinados ao estudo, decidiu-se por utilizá-la, uma vez que a moldagem de blocos em diferentes equipamentos, pode alterar o resultado do lote de blocos destinado à confecção dos prismas e paredes do estudo, prejudicando o estudo.

\subsection{Produção dos $\underline{\text { blocos }} \underline{\text { de }} \underline{\text { alvenaria }}$}

Todos os materiais destinados à produção dos blocos de concreto, foram transportados à fábrica: os agregados secos ao ar, separados pelas distintas frações e natureza (naturais e reciclados) em 15 tambores descobertos de 200 litros e os sacos de cimento intactos e empilhados em palet. 
Para que a fábrica não fosse obrigada a interromper sua produção própria, retirando os agregados dos silos e alterando o sistema de dosagem da balança, os blocos foram produzidos após a limpeza da vibro-prensa e do misturador de eixo horizontal, com o termino do turno da fábrica. Permanecendo apenas alguns funcionários para pesar os materiais em uma balança móvel com capacidade de $150 \mathrm{~kg}$, os blocos de $14 \times 19 \times 39 \mathrm{~cm}$ e $14 \times 19 \times 19 \mathrm{~cm}$ foram cuidadosamente dosados separadamente em várias séries, mantendo o traço original de $1: 4,35: 3,96: 0,96$.

Ressalta-se que pelo horário de produção, das 18:00hs às 24:00hs, os dois lotes de blocos permaneceram isentos da irradiação solar, com temperatura ambiente em torno de $27^{\circ} \mathrm{C}$ e elevada umidade relativa do ar devido à proximidade de um córrego local. Devido à véspera de feriado prolongado, os blocos permaneceram a chapa metálica da vibro-prensa, de sustentação de 3 blocos, por 5 dias (Figura 5.1). Neste período, os blocos foram curados por irrigação a cada hora pelo vigia da fábrica. Desta forma, os blocos só foram retirados das chapas após obterem rigidez e resistência mecânica, garantindo a redução da probabilidade de fissuração ao retirálos das chapas metálicas.

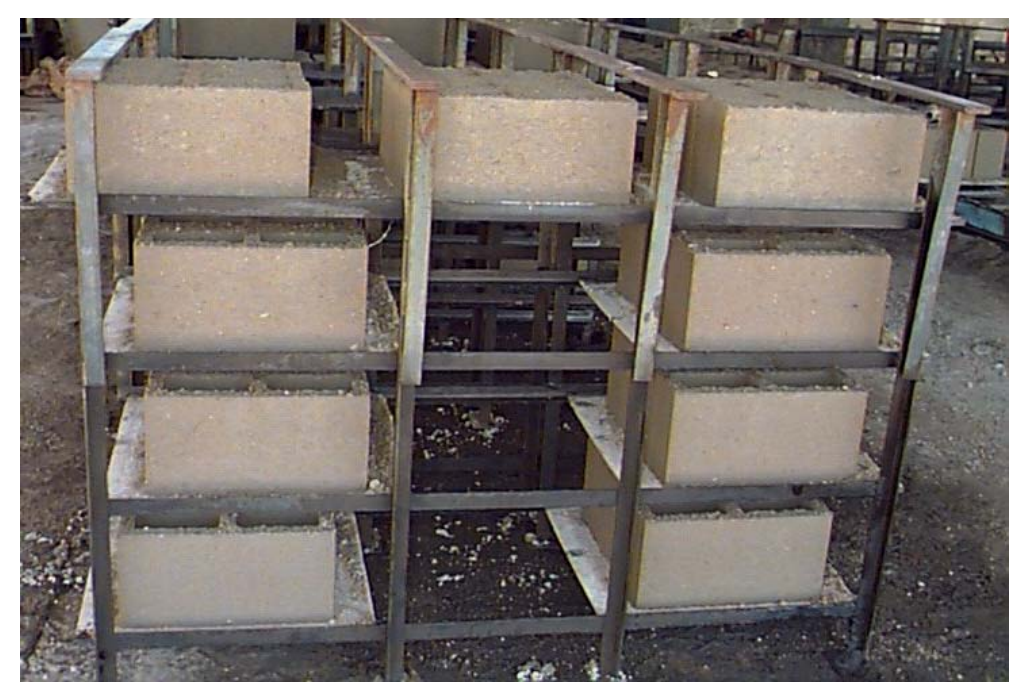

Figura 5.1 - Permanência dos blocos às chapas metálicas por 5 dias

Os lotes de blocos foram transportados somente ao $6^{\circ}$ dia de idade, para que fosse garantida a não fissuração dos mesmos durante o transporte ao pátio do Laboratório de Estruturas. 


\subsection{Confeccão de paredes $\underline{\text { e prismas }} \underline{\text { de alvenaria }}$}

Depois de obtido o lote de blocos de concreto, contendo agregados reciclados, foram confeccionadas paredes e prismas. Com o racionamento de energia elétrica no país, as usinas cimenteiras interromperam a produção de cimento CP IIE devido ao elevado consumo de energia elétrica em relação aos demais, e aumentaram a produção de CP IIF. Desta forma, o CP IIE foi temporariamente extinto no comércio. Sendo assim, as argamassas produzidas neste trabalho, para a confecção das paredes e prismas, utilizaram o CP IIF-32 como cimento padrão.

Esta alteração da constituição dos cimentos não foi significativa, pois, como o principal parâmetro de comparação, entre as argamassas contendo agregado natural e reciclado, era a resistência à compressão aos 28 dias de idade, a classe de resistência do cimento utilizada no estudo era idêntica às que realmente seriam utilizadas às argamassas, ou seja, aos 28 dias de idade, ambos os cimentos possuiriam a mesma resistência à compressão.

\subsubsection{Prismas e painéis de alvenaria destinados à determinação da resistência à compressão axial}

Os prismas e paredes, independente da presença de revestimento, foram confeccionados sobre um calço de madeira para facilitar o transporte à Máquina Universal de Ensaios. Durante o assentamento de ambas as argamassas, contendo agregado natural e reciclado, verificou-se a capacidade absorvente dos blocos de concreto de parte da água presente na argamassa, conforme Figura 5.2.

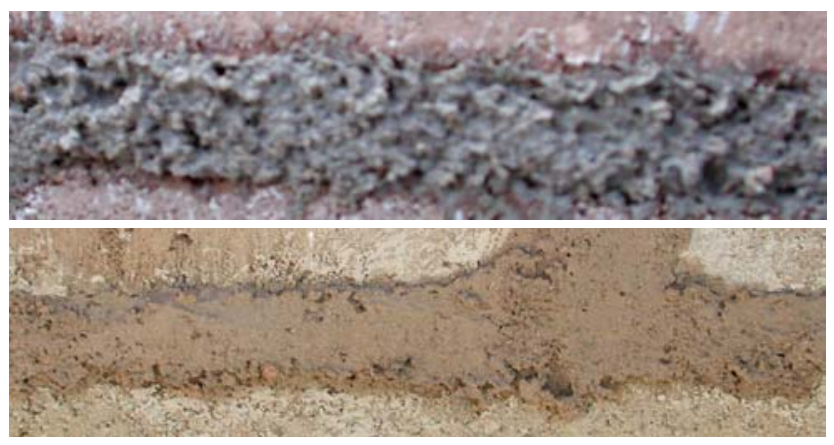

a) argamassa com agregado natural

Figura 5.2 - Absorção de água da argamassa de assentamento pelo bloco de concreto 
Da mesma forma, durante a aplicação do chapisco e dos revestimentos executadas com camada única de $1 \mathrm{~cm}$ por face, verificou-se que os blocos de concreto e a camada de chapisco, também absorveram água (Figura 5.3), possibilitando apresentar retração hidráulica, que influencia na perda de resistência mecânica e aderência entre o revestimento e o substrato. Ressalta-se que o traço de chapisco utilizado foi com relação de 1:3 (volume) de argamassa simples de cimento e areia natural, cuja relação a/c foi estabelecida e aplicada manualmente pelo pedreiro responsável, com o objetivo de aproximar-se à realidade das construções residenciais corriqueiras.

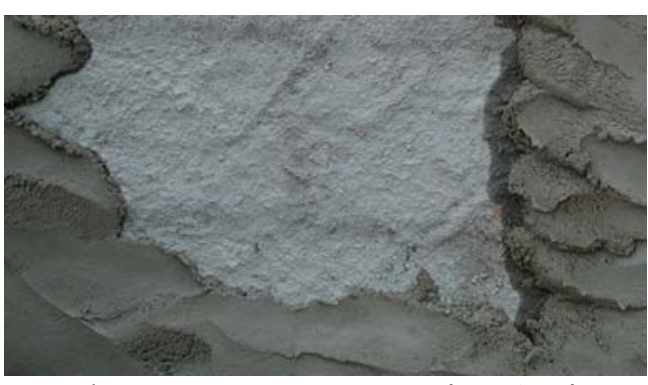

a) argamassa com agregado natural

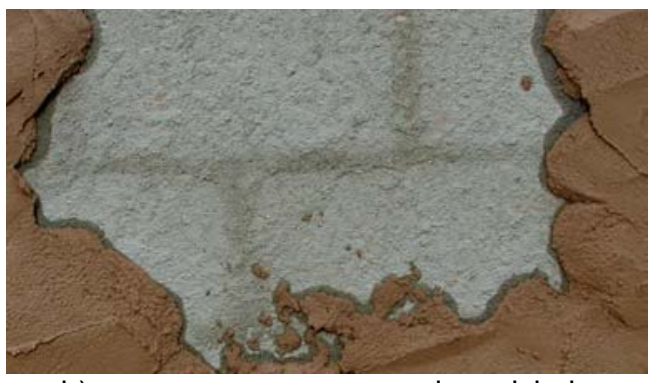

b) argamassa com agregado reciclado

Figura 5.3 - Absorção de água da argamassa de revestimento pelo

\section{bloco de concreto e chapisco}

Conforme citado na revisão bibliográfica, a absorção permite que as parcelas de água livres, juntamente com partículas de cimento, sejam succionadas pelo substrato, promovendo assim a aderência química.

Verificou-se que, apesar da argamassa com agregado reciclado possuir resistência superior ao natural, todos os revestimentos contendo argamassa reciclada apresentaram elevada retração após 5 minutos das superfícies serem sarrafeadas, mesmo depois de regularizadas com a desempenadeira (Figura 5.4).

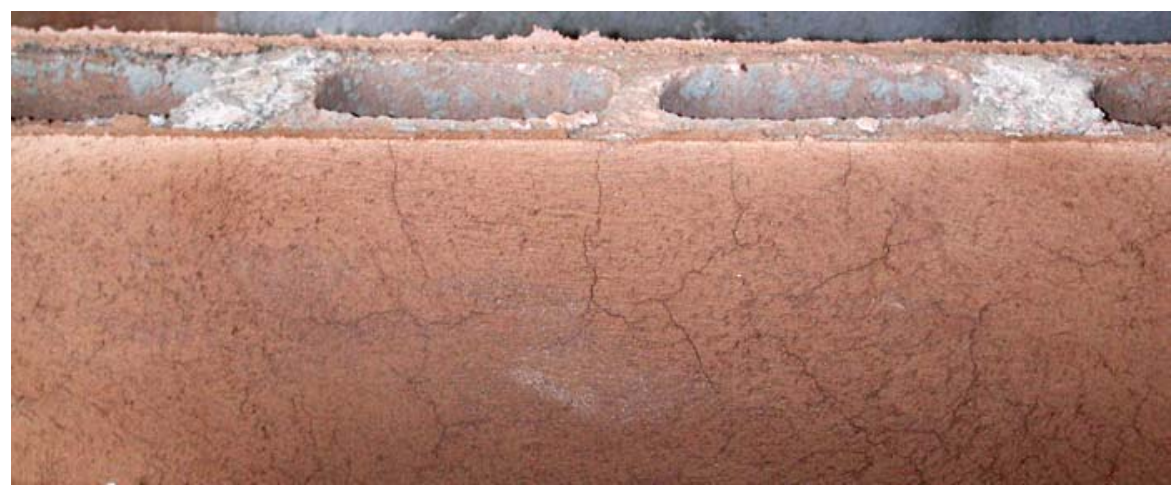

Figura 5.4 - Retração no revestimento de argamassa reciclada 
Apresentam-se na Figura 5.5, as paredes com seus respectivos prismas, todos confeccionados dentro do galpão do Laboratório de Estruturas. Houve a necessidade de regularizar a superfície superior das paredes, utilizando uma argamassa com traço de 1:3, em massa, de cimento e areia.

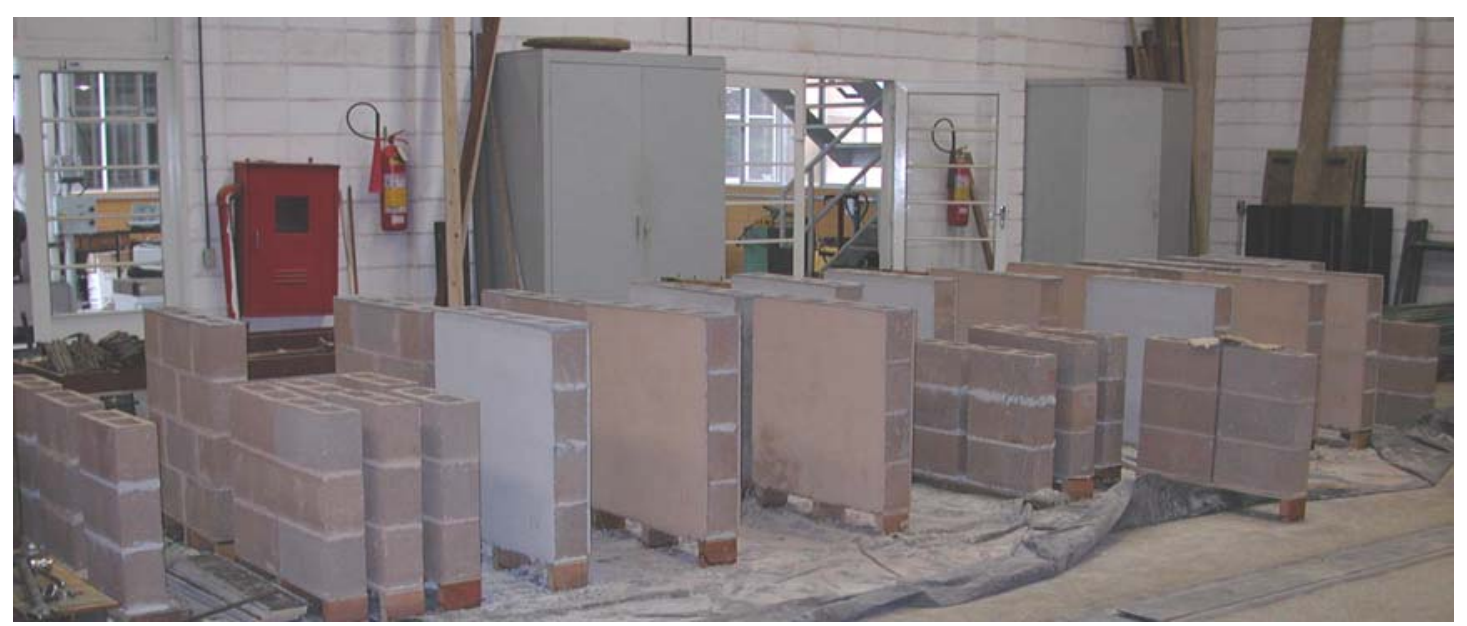

Figura 5.5 - Vista das paredes e prismas de alvenaria

\subsubsection{Painel para o ensaio de aderência à tração do revestimento}

O mesmo processo de assentamento e revestimento foi executado, porém executada com uma camada de 2,5cm de espessura por face. Entretanto, estes painéis foram confeccionados no pátio do Laboratório de Estruturas, para que as intempéries a que estão sujeitas, reproduzam os mesmos efeitos em obra. Contudo, ao estarem expostas à elevada, temperatura ocasionada pelo sol, e às rajadas de vento, o processo de retração nos revestimentos contendo agregado reciclado foi maior, comparada às paredes protegidas e confeccionadas no galpão, mesmo quando mantida a cura dos revestimentos por irrigação de água e a proteção por lona plástica, nos primeiros 7 dias de idade. Aos 10 dias de idade, as paredes foram grauteadas para aumentar sua rigidez, devido à possibilidade de haver deslocamento entre as fiadas de argamassa dos blocos durante o ensaio de aderência, fixando-se ganchos para possibilitar a locomoção e fixação do painel.

Aos 25 dias de idade, as superfícies foram preparadas, delimitando-se a área a receber a distribuição de tensões do dispositivo de ensaio, com uma serra de copo diamantada, acoplada à perfuratriz de extração de testemunhos, fixada em um 
guia de madeira para que a perfuração fosse perpendicular à superfície do revestimento, garantindo a estabilidade da broca durante o corte e evitando vibrações prejudiciais à integridade do revestimento, conforme pode ser visto na Figura 5.6b. Foram preparados corpos-de-prova com e sem fissuras de retração nas argamassas contendo agregado reciclado, possibilitando analisar a influência da perda de aderência da argamassa oriunda da retração.

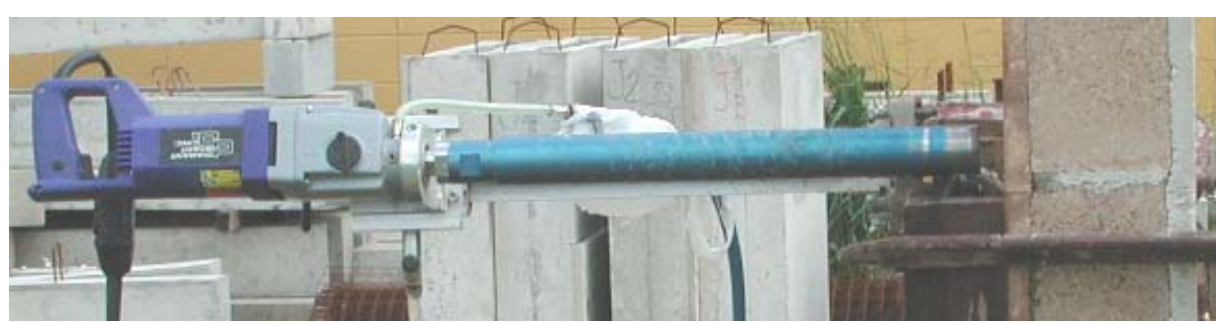

a) Vista da perfuratriz fixada à alvenaria

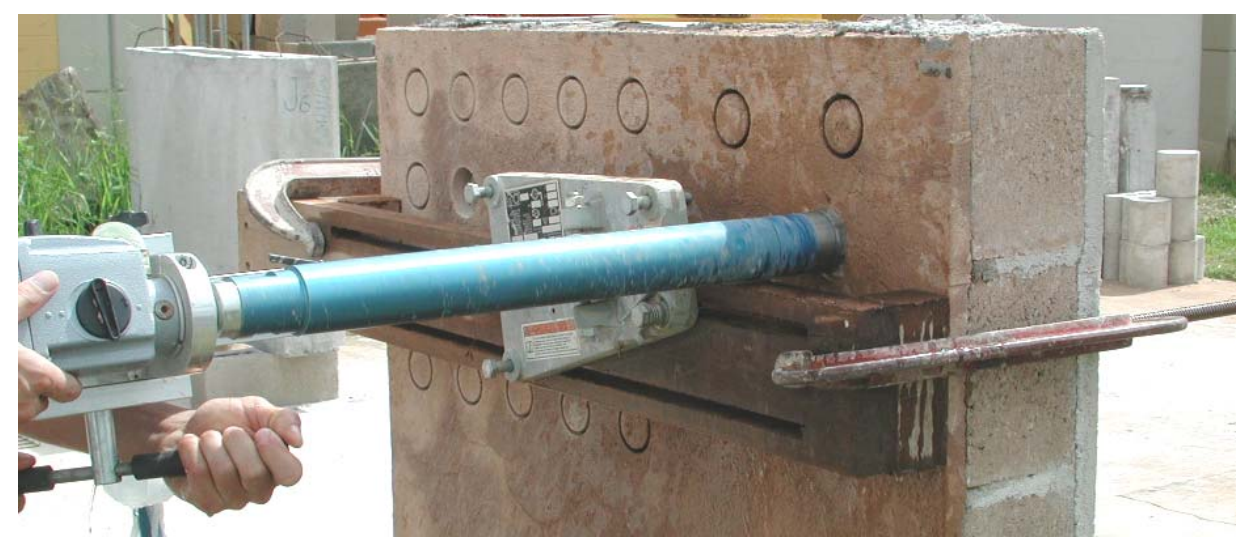

b) Vista do posicionamento da perfuratriz ao guia para o corte do revestimento

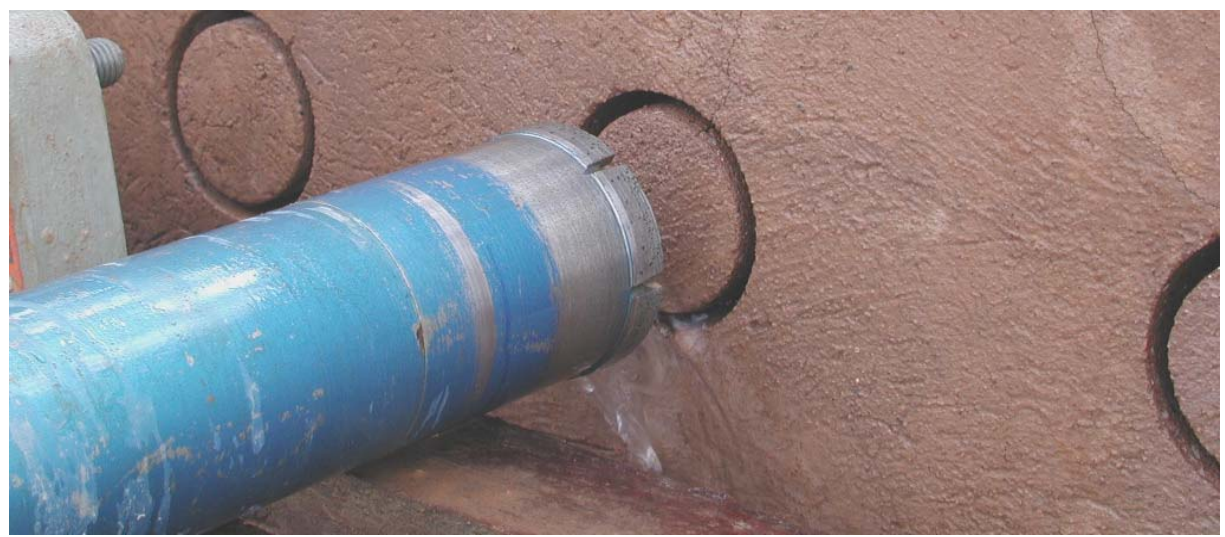

c) Vista detalhada do corte do revestimento

\section{Figura 5.6 - Dispositivo de corte do revestimento}

Com a superfície seca, colaram-se, em cada área delimitada, pastilhas de alumínio contendo rosca interna, para unirem-se ao dispositivo de retirada da argamassa, conforme Figura 5.7. O adesivo utilizado para a fixação das pastilhas às 
argamassas foi o Sikadur 31, um epóxi bi-componente com consistência pastosa, recomendada por BORTOLUZzo (2000) devido sua rápida aderência as primeiras 48hs. Para evitar interferência da flexão ao ensaio, antes de terminar o fim de pega do adesivo, retirou-se o excesso do adesivo encontrado no perímetro dos corpos-deprova e utilizou-se fita crepe para evitar o escorregamento da pastilha no plano vertical, garantindo que a pastilha permaneça no eixo perpendicular à superfície.

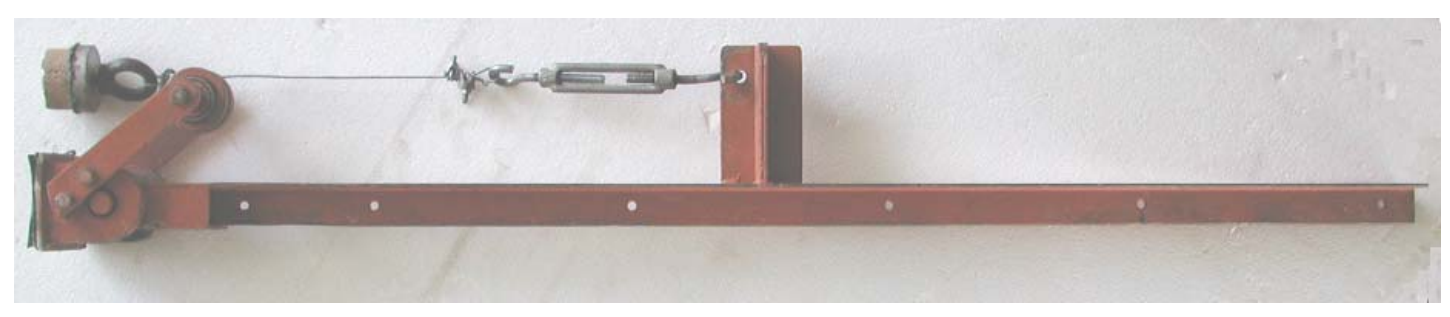

Figura 5.7 - Vista do dispositivo de aderência à tração da argamassa de revestimento 


\section{善 6 ANÁLISE DOS $\underline{\text { RESULTADOS }}$}

Neste Capítulo, serão apresentados e discutidos os resultados de caracterização do lote do bloco de concreto contendo agregados naturais e reciclados, destinado à confecção dos painéis de alvenaria, além de analisar a influência das argamassas, contendo agregados naturais e reciclados quando utilizados como componentes de assentamento e revestimento, nos ensaios de resistência à compressão e módulo de deformação das paredes. No entanto, devido à grande importância da resistência da aderência à tração dos revestimentos, e da profundidade de carbonatação da argamassa de assentamento, estes parâmetros tornam-se indispensáveis para a análise da influência dos distintos revestimentos.

Contudo, as correlações de eficiência entre painéis e prismas, em função das distintas argamassas de assentamento e revestimento são necessárias, pois possibilitam comparar e estimar os comportamentos mecânicos dos mesmos, quando prismas são moldados e ensaiados. 


\subsection{Ensaios em $\underline{\text { blocos, }}$ prismas $\underline{\text { e paredes }}$}

\subsubsection{Caracterização dos lotes de blocos de concreto}

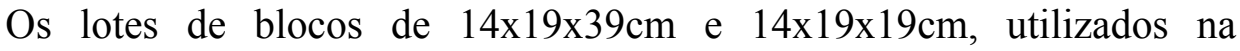
confecção dos prismas e paredes de alvenaria, foram caracterizados para verificar a qualidade dos mesmos. Segundo a especificação da NBR 6136/94, a amostra de cada lote deve ser ensaiada para determinar a resistência característica à compressão $\left(f_{b k}\right)$, a absorção de água, teor de umidade e área líquida, e a retração por secagem, segundo a MB-116/91, a MB-3459/91 e a MB-3458/91, respectivamente. Contudo, esta última não foi realizada pois considerou-se que a retração por secagem do bloco não superaria $0,065 \%$. Os resultados individuais dos ensaios, referentes à caracterização dos lotes de blocos apresentam-se no Anexo A.

\subsubsection{Resistência à compressão}

As amostras foram preparadas, retirando-se as saliências de pasta de cimento dos blocos, conforme apresentado na Figura 4.4d. Além de ocultar e extrapolar a determinação da área bruta, a presença destas imperfeições altera a regularização do capeamento com enxofre. A superação dos limites de $3 \mathrm{~mm}$ de espessura ou $5^{\circ}$ de tolerância na inclinação do capeamento, segundo a especificação da MB-116/91, resulta na redução do carregamento máximo aplicado $\left(\mathrm{F}_{\mathrm{m}}\right)$.

A Tabela 6.1 apresenta os resultados dos ensaios de resistência média à compressão da área bruta dos blocos $\left(\mathrm{f}_{\mathrm{bm}}\right)$ inteiros de dimensões de $14 \times 19 \times 39 \mathrm{~cm}$ e de meio bloco de 14x19x19cm, determinados pela média de seis amostras de cada lote, em cada idade considerada. Para efeito deste trabalho, a resistência característica à compressão dos blocos $\left(\mathrm{f}_{\mathrm{bk}}\right)$ é de $8,5 \mathrm{MPa}$, determinada aos 28 dias de idade.

Tabela 6.1 - Determinação da resistência característica à compressão do lote de blocos de concreto

\begin{tabular}{|c|c|c|c|c|c|c|c|c|}
\hline \multirow[t]{2}{*}{ modulação } & \multirow{2}{*}{$\begin{array}{l}\text { idade } \\
\text { (dias) }\end{array}$} & \multirow[t]{2}{*}{$F_{m}(k N)$} & \multirow{2}{*}{$\begin{array}{c}\mathrm{f}_{\mathrm{bm}} \\
(\mathrm{MPa})\end{array}$} & \multicolumn{3}{|c|}{$\overline{f_{b}(M P a)}$} & \multirow[t]{2}{*}{$\mathrm{f}_{\mathrm{bk}}(\mathrm{MPa})$} & \multirow[t]{2}{*}{ CV (\%) } \\
\hline & & & & (In) & $\mathrm{bm}$ & . Ib1 & & \\
\hline \multirow{3}{*}{$19 \times 14 \times 39$} & ? & 532,9 & 9,87 & 6,69 & 8,39 & 6,66 & 7,0 & 14,4 \\
\hline & 28 & 605,3 & 11,22 & 9,06 & 9,54 & 8,22 & $8,5(121,4)$ & 13,9 \\
\hline & 250 & 797,6 & 14,79 & 12,63 & 12,57 & 11,80 & $12,0(171,4)$ & 9,7 \\
\hline \multirow{2}{*}{$19 \times 14 \times 19$} & 7 & 311,8 & 10,43 & 8,17 & 8,87 & 8,28 & 8,5 & 8,2 \\
\hline & 28 & 397,2 & 14,87 & 5,83 & 12,64 & 9,44 & $9,5(111,8)$ & 26,8 \\
\hline
\end{tabular}


Como pode ser verificada na Tabela 6.1, a resistência característica à compressão do bloco inteiro é menor que a do bloco de meio. Outra importante característica é o acréscimo de resistência de concretos com abatimento nulo. Conforme a Figura 6.1, a resistência característica aos 7 dias de idade é muito elevada quando comparada aos 28 dias. Dessa forma, este tipo de concreto, caracterizado pelo abatimento nulo, deve ser mais influenciado pelas intempéries nas primeiras idades, isto é, a cura tem maior influência sobre a temperatura, umidade relativa do ar e do concreto e da velocidade do vento para impedir elevada perda de água. Com a redução da quantidade de água destinada à hidratação do cimento, qualquer quantidade de água que é retirada da matriz do cimento é significativa.

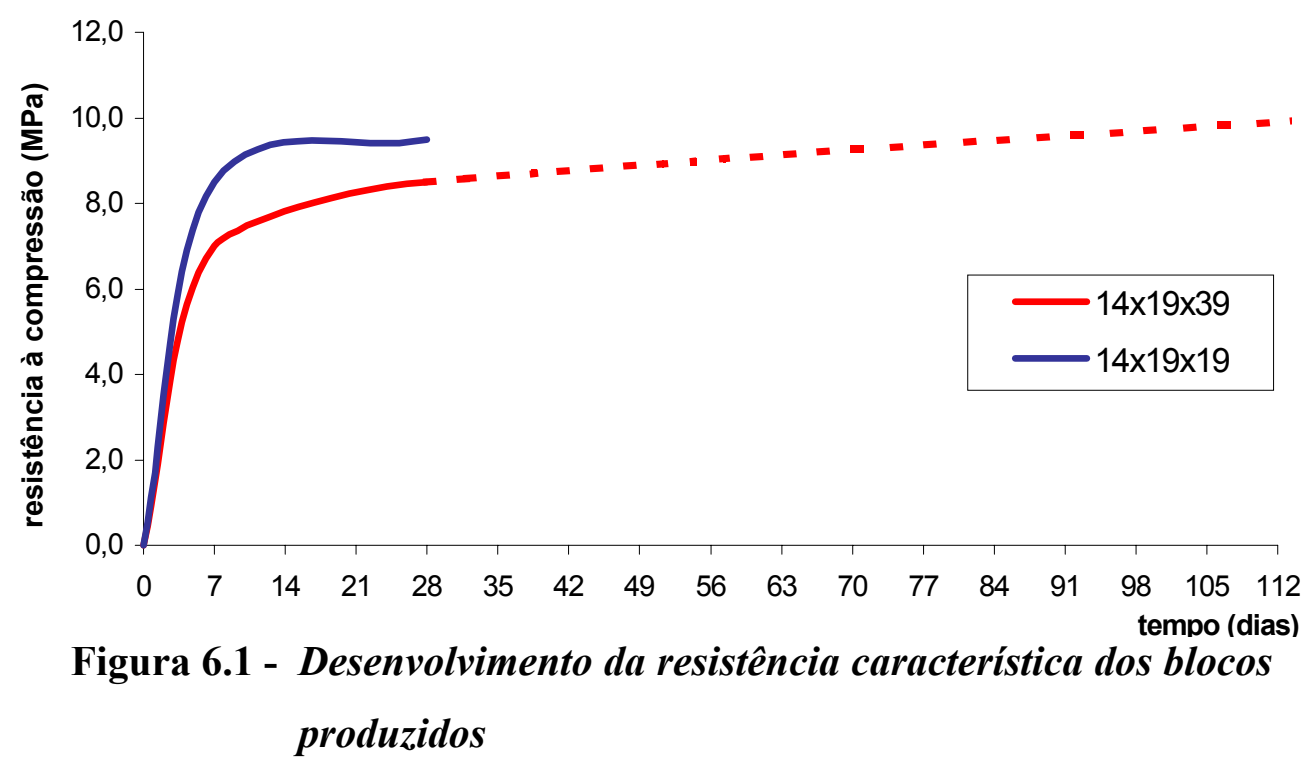

Como o acréscimo de resistência após os primeiros sete dias é pouco significativo, estima-se que em idades avançadas, a resistência característica à compressão do bloco seja pouco superior aos 28 dias. Apresenta-se na Figura 6.2, a ruptura típica dos blocos de concreto de alvenaria resultante do ensaio de resistência à compressão axial. Nota-se que, no septo longitudinal, a fissuração ocorreu no eixo horizontal, paralelo à superfície de assentamento. Entretanto, nos septos transversais, a fissuração ocorreu de forma brusca, possivelmente pela rigidez. Segundo OLIVEIRA (2001), a deformação na direção paralela ao eixo de carregamento, nos septos transversais é menor que a dos septos longitudinais. Logo, a tensão concentra-se na curvatura das mísulas dos blocos vazados. 


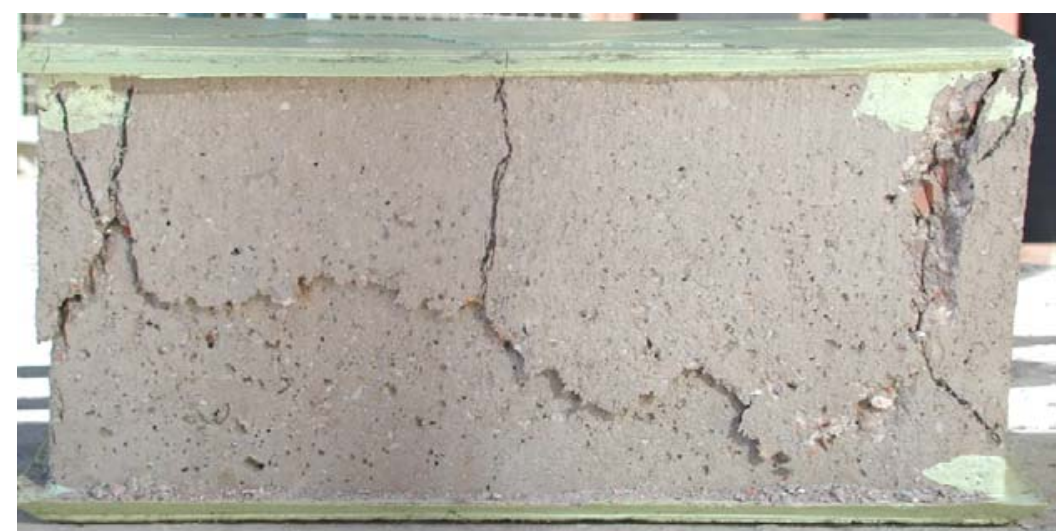

Figura 6.2 - Ruptura típica dos blocos vazados de concreto de alvenaria com função estrutural

\subsubsection{Absorção de água, área líquida, massa específica e teor de umidade}

Ao determinar a área líquida dos blocos segundo a MB-3459/91, expostos na Tabela 6.2 , percebe-se que $56,1 \%$ e 59,9\% das áreas brutas dos blocos inteiros e de meio, respectivamente, são constituídas por superfície útil sólida. Isto explica a maior resistência do bloco de meio em relação ao bloco inteiro, devido à menor área vazada em relação à área bruta. Este ensaio foi realizado no $6^{\circ}$ dia de idade do bloco, na mesma data de entrega dos lotes dos blocos para haver uma coerência com o teor de umidade dos mesmos.

Tabela 6.2 - Determinação do teor de umidade, absorção, área líquida e massa específica dos blocos

\begin{tabular}{c||cc|cc|cc|cc}
\hline \hline \multirow{2}{*}{ série } & \multicolumn{2}{c|}{ umidade } & \multicolumn{2}{c|}{ absorção } & \multicolumn{2}{c|}{ área líquida } & \multicolumn{2}{c}{ massa específica } \\
& média(\%) & CV (\%) & média(\%) & CV (\%) & média $\left(\mathrm{cm}^{2}\right)$ & CV (\%) & média $\left(\mathrm{g} / \mathrm{cm}^{3}\right)$ & CV $(\%)$ \\
\hline \hline $19 \times 14 \times 39$ & 53,9 & 10,9 & 8,1 & 8,8 & 306,0 & 0,4 & 1,99 & 0,4 \\
$19 \times 14 \times 19$ & 50,4 & 9,8 & 8,9 & 4,1 & 159,3 & 0,6 & 1,97 & 2,7 \\
\hline \hline
\end{tabular}

A massa específica não obteve variação significativa quando comparada ao estudo de traço. Contudo, as maiores diferenças encontram-se na absorção e na resistência característica à compressão, explicadas pelas seguintes hipóteses:

a ) Eficiência do misturador forçado, de eixo horizontal. No estudo de traço, devido a pouca quantidade de material de cada traço, a ser homogeneizado, estes foram misturados no chão, utilizando enxada, possibilitando perda de água para o meio externo e a contaminação por óleo e finos presentes no piso da fábrica. Quando se utilizou o misturador de eixo horizontal, além de impedir a perda de água e a 
contaminação por agregados de diferentes origens, este homogeneíza melhor a mistura por tratar-se de um sistema em que a principal força exercida à mistura dos agregados com massas específicas distintas é a força gravitacional.

b ) Produção realizada no período noturno e permanência dos blocos a chapa metálica de produção por 5 dias e as demais alterações descritas no item 5.1, possibilitando aos lotes de blocos obterem resistências suficientes para que não surgissem micro-fissuras ao se retirar o conjunto de três blocos da chapa;

c ) Mudança de forma metálica da fábrica. Inicialmente, todo o estudo de traço foi baseado na fabricação de blocos com um raio de curvatura da mísula e pequena espessura das paredes longitudinais e transversais, resultando na baixa área líquida dos blocos piloto apresentados no Anexo A. Como a produção de artefatos de concreto com abatimento nulo resulta no elevado desgaste das formas metálicas, o fabricante alterou a configuração da geometria das mesmas, aumentando o raio das mísulas de acomodação e das espessuras das paredes longitudinais e transversais, para estarem padronizadas segundo a NBR 6136/94. Desta forma, ao se produzirem os lotes de blocos destinados à produção das paredes, estes apresentaram maior área líquida comparados aos blocos de estudo.

As citações acima não devem ser consideradas como falta de planejamento, mas sim como melhoria na qualidade da produção dos blocos devido a pequenas alterações na tecnologia do concreto e na produção.

\subsubsection{Resistência à compressão dos prismas e paredes}

Os ensaios de paredes de alvenaria realizados nesta pesquisa foram feitos com deformação controlada, à velocidade do pistão de $0,005 \mathrm{~mm} / \mathrm{s}$, permitindo obterse a curva tensão-deformação da estrutura até o momento da ruína e após o pico de carregamento, possibilitando analisar a resistência, rigidez e ductilidade do elemento estrutural. As placas do tipo "soft-board" foram colocadas, apenas sobre os blocos e não no revestimento, em cada uma das superfícies solicitadas, conforme demonstra a Figura 6.3, para que o capeamento não provocasse o descolamento do revestimento da alvenaria por flexão, além de obter o comportamento do revestimento quando parte do carregamento é transferido, por aderência, pelo núcleo do painel. 


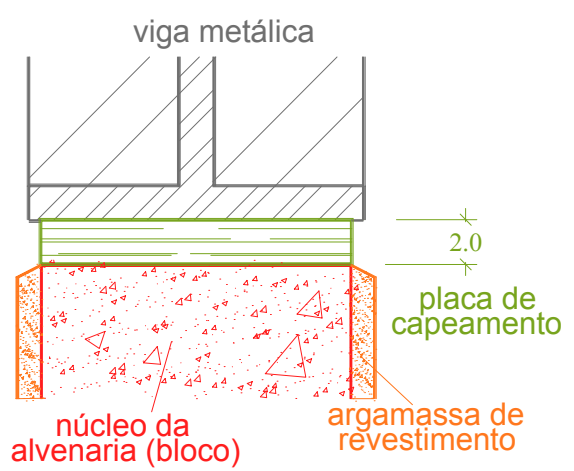

Figura 6.3 - Distribuição do carregamento à alvenaria

Em função da natureza do agregado, natural $(\mathrm{N})$ e reciclado $(\mathrm{R})$, presente apenas nas argamassas, as 6 séries de paredes são identificadas por letras, sendo que a primeira representa o tipo de agregado contido na argamassa de assentamento e a segunda, na argamassa de revestimento.

Ressalta-se que inicialmente, foi feito 1 prisma por parede, porém sem revestimento; os prismas foram moldados e ensaiados na mesma idade. Contudo, com a finalidade de se obter correlações também nos prismas, em função da presença de revestimentos, moldaram-se e romperam-se novos prismas, porém chapiscados e revestidos da mesma forma, com os mesmos materiais e com a mesma idade que os anteriores. Dessa forma, os ensaios anteriores e os novos foram realizados entre $38 \pm 3$ dias e $286 \pm 1$ dias de idade após a fabricação dos blocos. A Tabela 6.3 apresenta a resistência última das paredes com seus respectivos prismas, em função da série. Devido a diferentes idades dos blocos, foram feitas correções na resistência dos prismas, em função da resistência média sem revestimento, para que haja uma correlação com as resistências das paredes. Os valores individuais são apresentados no Anexo B, cujos valores da Tabela B.2 referem-se ao ensaio de prismas novos.

Tabela 6.3 - Resistência à compressão média de prismas e paredes, com e sem revestimentos

\begin{tabular}{|c|c|c|c|c|c|c|c|c|}
\hline & elemento & parâmetro & $\mathrm{R}$ & $\mathrm{RN}$ & RR & $\mathrm{N}$ & $\mathrm{NN}$ & NR \\
\hline \multirow{6}{*}{ anterior } & \multirow{3}{*}{ prisma } & média (MPa) & 6,45 & 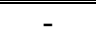 & - & 5,96 & - & - \\
\hline & & $\mathrm{Sd}(\mathrm{MPa})$ & 0,67 & - & - & 0,78 & - & - \\
\hline & & CV (\%) & 10,40 & - & - & 13,16 & - & - \\
\hline & \multirow{3}{*}{ parede } & média (MPa) & 6,45 & 5,08 & 5,94 & 4,88 & 4,79 & 4,81 \\
\hline & & $\mathrm{Sd}(\mathrm{MPa})$ & 0,71 & 0,53 & 0,40 & 0,23 & 0,63 & 1,15 \\
\hline & & CV (\%) & 11,07 & 10,49 & 6,78 & 4,77 & 13,08 & 23,97 \\
\hline \multirow{3}{*}{ novo } & \multirow{3}{*}{ prisma } & média (MPa) & 7,77 & 6,42 & 6,95 & 7,17 & 5,65 & 6,14 \\
\hline & & Sd (MPa) & 1,32 & 0,67 & 0,79 & 0,76 & 0,86 & 0,44 \\
\hline & & CV $(\%)$ & 17,03 & 10,39 & 11,36 & 10,54 & 15,19 & 7,18 \\
\hline corrigido & prisma & média (MPa) & 6,45 & 5,33 & 5,77 & 5,96 & 4,70 & 5,11 \\
\hline
\end{tabular}


Verifica-se que somente as paredes assentadas com argamassa de agregados naturais $\left(\mathrm{N}_{-}\right)$, independentes da presença de revestimentos de argamassa, possuem praticamente a mesma resistência à compressão, com influência não significativa do revestimento. No entanto, estas paredes resultaram em resistências inferiores quando comparadas às que contem agregado reciclado (R_).

Em relação à perda de resistência das paredes assentadas com argamassa contendo agregado reciclado, em função da presença de revestimento, o processo de carbonatação da argamassa de assentamento pode ter sido a principal responsável, o que será discutido adiante.

Comparando as paredes sem revestimentos de mesmas dimensões, com mesma argamassa de assentamento contendo agregados naturais, porém utilizando blocos de concreto com resistências médias à compressão de $10,8 \mathrm{MPa}$ e $22,9 \mathrm{MPa}$, com resistência característica de 9,0MPa e 20,0MPa, respectivamente, JUSTE (2001) obteve paredes com 4,12MPa e 5,65MPa de resistência média. Nota-se que a utilização de blocos com resistência média à compressão praticamente duplicada, não significa resultar na mesma taxa de acréscimo na resistência da parede, conforme explícito pela BS 5628 part 1 (1978), representada pelo gráfico da Figura 2.13.

Para que seja possível estimar a resistência de cálculo à compressão das paredes segundo a NBR 10837/85, a Tabela 6.4 apresenta as correlações de eficiência entre as resistências de paredes $\left(f_{p a}\right)$ e prismas $\left(f_{p r}\right)$ em relação apenas com os blocos de concreto.

Tabela 6.4 - Correlações de eficiência entre as resistências à compressão das paredes e prismas em função da resistência característica à compressão do bloco

\begin{tabular}{c||c|c|c|c}
\hline \hline \multirow{2}{*}{ série } & \multirow{2}{*}{$\mathrm{f}_{\mathrm{pa}}(\mathrm{MPa})$} & \multirow{2}{*}{$\mathrm{f}_{\mathrm{pr}}(\mathrm{MPa})$} & \multicolumn{2}{|c}{ relações de eficiência } \\
& & & $\mathrm{f}_{\mathrm{pa}} / \mathrm{f}_{\mathrm{bk}}$ & $\mathrm{f}_{\mathrm{pr}} / \mathrm{f}_{\mathrm{bk}}$ \\
\hline \hline $\mathrm{R}$ & 6,45 & 6,45 & 0,76 & 0,76 \\
$\mathrm{RN}$ & 5,08 & 5,33 & 0,63 & 0,63 \\
$\mathrm{RR}$ & 5,94 & 5,77 & 0,68 & 0,68 \\
\hline $\mathrm{N}$ & 4,88 & 5,96 & 0,57 & 0,70 \\
$\mathrm{NN}$ & 4,79 & 4,70 & 0,56 & 0,55 \\
$\mathrm{NR}$ & 4,81 & 5,11 & 0,57 & 0,60 \\
\hline $\mathrm{N}^{*}$ & 4,12 & 7,93 & 0,46 & 0,88 \\
$\mathrm{~N}^{* *}$ & 5,65 & 9,22 & 0,28 & 0,46 \\
\hline \hline & \multicolumn{4}{|c}{} \\
${ }^{*} \mathrm{f}_{\mathrm{bk}}=9,0 \mathrm{MPa}$ (JUSTE, 2001) \\
${ }^{* *} \mathrm{f}_{\mathrm{bk}}=20,0 \mathrm{MPa}$ (JUSTE, 2001)
\end{tabular}


Desse modo, as resistências das argamassas utilizadas foram ideais para a resistência à compressão do bloco de concreto, pois os valores de eficiência dos prismas, em relação aos blocos com agregado reciclado, apresenta-se entre $76 \%$ e $63 \%$ para argamassa de assentamento contendo agregado reciclado e entre $70 \%$ e 55\% para agregado natural. Em comparação, segundo RAMALHO \& CORRÊA (1999), os valores no Brasil variam de $50 \%$ a $90 \%$ para blocos de concreto, e de $0,3 \%$ a $0,4 \%$ para blocos cerâmicos, assentados com argamassa de agregado natural. Dependendo da classe de resistência do bloco, a resistência da argamassa influencia muito pouco a resistência última do prisma, pois a argamassa trabalha em um estado multiaxial de tensões, diferente da situação quando analisa-se apenas o ensaio de compressão simples de corpos-de-prova da argamassa.

A Tabela 6.5 apresenta as correlações de resistência média à compressão entre as paredes e prismas, em função da série, possibilitando analisar a influência entre paredes e prismas de diferentes séries. Um fato importante verificado foi o ganho de resistência obtido pela parede RR quando esta substitui a parede RN, contribuindo para o acréscimo da resistência da alvenaria em 17\%. Entretanto, o aumento de $23 \%$ da resistência da parede RR sobre a NR, comprova que a substituição da argamassa, de assentamento e de revestimento, contendo agregado natural pelo agregado reciclado, possibilita aumentar a resistência à compressão da parede.

Tabela 6.5 - Correlações de resistência à compressão axial entre paredes $e$ prismas, com e sem revestimentos

\begin{tabular}{|c|c|c|c|c|c|c|c|c|c|c|c|c|c|}
\hline \multirow{2}{*}{\multicolumn{2}{|c|}{$f_{X} / f_{Y}$}} & \multicolumn{12}{|c|}{ are } \\
\hline & & $\mathrm{R}$ & $\mathrm{RN}$ & $\mathrm{RR}$ & $\mathrm{N}$ & NN & NR & $\mathrm{R}$ & $\mathrm{RN}$ & $\mathrm{RR}$ & $\mathrm{N}$ & $\mathrm{NN}$ & NR \\
\hline \multirow{6}{*}{ parede } & $\mathrm{R}$ & 1,00 & 0,79 & 0,92 & 0,76 & 0,74 & 0,75 & 1,00 & 0,83 & 0,90 & 0,93 & 0,73 & 0,79 \\
\hline & $\mathrm{RN}$ & 1,27 & 1,00 & 1,17 & 0,96 & 0,94 & 0,95 & 1,27 & 1,05 & 1,14 & 1,17 & 0,93 & 1,01 \\
\hline & $\mathrm{RR}$ & 1,09 & 0,85 & 1,00 & 0,82 & 0,81 & 0,81 & 1,09 & 0,97 & 0,97 & 1,00 & 0,79 & 0,86 \\
\hline & $\mathrm{N}$ & 1,32 & 1,04 & 1,22 & 1,00 & 0,98 & 0,99 & 1,32 & 1,09 & 1,18 & 1,22 & 0,96 & 1,05 \\
\hline & NN & 1,34 & 1,06 & 1,24 & 1,02 & 1,00 & 1,00 & 1,35 & 1,11 & 1,20 & 1,24 & 0,98 & 1,06 \\
\hline & NR & 1,34 & 1,05 & 1,23 & 1,01 & 1,00 & 1,00 & 1,34 & 1,11 & 1,20 & 1,24 & 0,98 & 1,06 \\
\hline \multirow{6}{*}{ prisma } & $\mathrm{R}$ & 1,00 & 0,79 & 0,92 & 0,76 & 0,74 & 0,75 & 1,00 & 0,83 & 0,90 & 0,92 & 0,73 & 0,79 \\
\hline & $\mathrm{RN}$ & 1,21 & 0,95 & 1,12 & 0,92 & 0,90 & 0,90 & 1,21 & 1,00 & 1,08 & 1,12 & 0,88 & 0,96 \\
\hline & $\mathrm{RR}$ & 1,12 & 0,88 & 1,03 & 0,85 & 0,83 & 0,83 & 1,12 & 0,92 & 1,00 & 1,03 & 0,81 & 0,88 \\
\hline & $\mathrm{N}$ & 1,08 & 0,85 & 1,00 & 0,82 & 0,80 & 0,81 & 1,08 & 0,89 & 0,97 & 1,00 & 0,79 & 0,86 \\
\hline & NN & 1,37 & 1,08 & 1,26 & 1,04 & 1,02 & 1,02 & 1,38 & 1,14 & 1,23 & 1,27 & 1,00 & 1,09 \\
\hline & NR & 1,26 & 0,99 & 1,16 & 0,96 & 0,94 & 0,94 & 1,27 & 1,05 & 1,13 & 1,17 & 0,92 & 1,00 \\
\hline
\end{tabular}


Como a resistência à compressão dos prismas e paredes são influenciados pelo tipo de argamassa, a Tabela 6.6 relata os resultados da resistência média à compressão dos corpos-de-prova cilíndricos de $5 \times 10 \mathrm{~cm}$, das argamassas $\left(\mathrm{f}_{\mathrm{am}}\right)$, representativos às paredes e prismas ensaiados, cujas argamassas com agregados reciclados possuem resistência superior às argamassas contendo agregado natural.

Tabela 6.6 - Resultado do ensaio de resistência à compressão de argamassa

\begin{tabular}{cc||c|c}
\hline \multicolumn{2}{c|}{ tipo de argamassa } & $\mathrm{f}_{\mathrm{am}}(\mathrm{MPa})$ & $\mathrm{CV}(\%)$ \\
\hline \multirow{2}{*}{ assentamento } & $\mathrm{R}$ & 6,18 & 10,7 \\
& $\mathrm{~N}$ & 5,23 & 26,1 \\
\hline \multirow{2}{*}{ revestimento } & $\mathrm{R}$ & 6,55 & 16,0 \\
& $\mathrm{~N}$ & 6,03 & 13,7 \\
\hline \hline
\end{tabular}

As distintas resistências das argamassas de assentamento e revestimento, que possuem as mesmas características relatadas no Capítulo 4 , são procedentes da diferença de idade de aplicação entre cada tipo de argamassa, da temperatura de moldagem e da evaporação de água da argamassa que resultou na queda de consistência, devido às amostras serem retiradas no instante em que foram utilizadas no terço inferior e superior das paredes.

\subsubsection{Módulo de deformação}

\subsubsection{Blocos de concreto}

Com a intenção de comparar os módulos de deformação secante do bloco de concreto quando é influenciado pelas juntas verticais de argamassa, instrumentaram-se transdutores nos septos longitudinais dos blocos intermediários de prismas e paredes (Figura 3.1). A Tabela 6.7 apresenta os resultados médios dos módulos de deformação dos blocos de concreto $\left(\mathrm{E}_{\mathrm{bm}}\right)$ determinados por prismas e paredes sem revestimento, por uma reta secante à $5 \%$ e $33 \%$ da tensão crítica e da respectiva deformação específica, conforme especificado pela ACI 530-92. Entretanto, a parábola ajustada à curva tensão-deformação dos gráficos contidos no Anexo B, pode não apresentar coerência quando se utiliza a tensão máxima. Dessa forma, a parábola ajustada que melhor representa a curvatura do gráfico, no trecho entre $5 \%$ e $33 \%$ da tensão crítica, ocorre a $80 \%$ da curva média tensão-deformação. 
Tabela 6.7 - Módulo de deformação secante do bloco de concreto sem revestimento

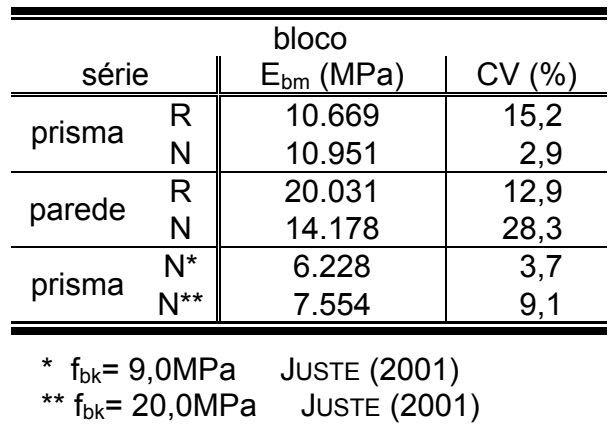

Como a argamassa não influencia na deformação do bloco nos prismas, o módulo de deformação médio dos blocos obtido foi de 10.810MPa. Comparando os blocos contendo agregados reciclados com os produzidos com agregados naturais, utilizados por JUSTE (2001), verifica-se que mesmo com grande resistência mecânica, os blocos com agregados naturais possuem menor rigidez. Além disto, os valores obtidos pelas paredes $\mathrm{R}$ e $\mathrm{N}$, representam em módulos de deformação do bloco quando são influenciados pelas juntas verticais de diferentes tipos de argamassa. Estes valores não representam os verdadeiros módulos de deformação secante dos blocos isolados, pois uma parcela do carregamento é transferida e absorvida pelas fiadas de argamassa, pois resultam em um acréscimo irreal na rigidez da estrutura. Entretanto, estes valores são interessantes para se analisar a influência das fiadas verticais de argamassa no bloco. Conforme expostos pela Tabela 6.8, o aumento de rigidez do bloco aumenta de $30 \%$ a $80 \%$, dependendo da argamassa utilizada.

Tabela 6.8 - Relação entre módulos de deformação do bloco, resultantes da relação entre parede / prisma

\begin{tabular}{cc||c|c}
\hline \hline \multicolumn{2}{c||}{ série } & \multicolumn{2}{c}{ parede } \\
& & $\mathrm{R}$ & $\mathrm{N}$ \\
\hline \hline \multirow{2}{*}{ prisma } & $\mathrm{R}$ & 1,88 & 1,33 \\
& $\mathrm{~N}$ & 1,83 & 1,29 \\
\hline \hline
\end{tabular}

Ao considerar a idade na determinação do módulo de deformação do bloco, comparando os resultados dos prismas anteriores e os novos, com e sem revestimento, verificou-se um aumento em sua rigidez. A Tabela 6.9 expõe o controle de qualidade dos módulos médios nos septos longitudinais $\left(\mathrm{E}_{\mathrm{sl}}\right)$ e transversais $\left(\mathrm{E}_{\mathrm{st}}\right)$ dos blocos, cujos valores individuais apresentam-se na Tabela B.2. O módulo determinado no septo longitudinal, nos prismas sem revestimento, aos 38 
dias de idade, era de 10.810MPa, e após 286 dias, aumentou para 11.903MPa. E ao determinar o módulo no septo transversal, este passa a $13.319 \mathrm{MPa}$, confirmando a maior rigidez. Entretanto, considerando a presença de revestimento nos septos longitudinais, verifica-se que o módulo de deformação varia com o revestimento.

Tabela 6.9 - Módulo de deformação médio dos septos dos blocos

\begin{tabular}{|c|c|c|c|c|c|c|c|c|}
\hline & septo & parâmetro & $\overline{\mathrm{R}}$ & RN & RR & $\mathrm{N}$ & $\overline{N N}$ & NR \\
\hline \multirow{3}{*}{ anterior } & \multirow{3}{*}{ longitudinal } & "médio (MPa) & 10.669 & - & - & 10.951 & - & - \\
\hline & & $\mathrm{Sd}(\mathrm{MPa})$ & 1.623 & - & - & 319 & - & - \\
\hline & & CV $(\%)$ & 15,22 & - & - & 2,91 & - & - \\
\hline \multirow{6}{*}{ novo } & \multirow{3}{*}{ longitudinal } & médio (MPa) & 12.149 & 11.812 & 11.683 & 11.656 & 13.294 & 11.790 \\
\hline & & $\mathrm{Sd}(\mathrm{MPa})$ & 203 & 1.079 & 746 & 480 & 554 & 537 \\
\hline & & CV (\%) & 1,60 & 9,13 & 6,38 & 4,12 & 4,17 & 4,56 \\
\hline & \multirow{3}{*}{ transversal } & médio (MPa) & 13.037 & 13.198 & 14.065 & 13.600 & 14.122 & 14.547 \\
\hline & & $\mathrm{Sd}(\mathrm{MPa})$ & 1.264 & 398 & 992 & 1327 & 435 & 828 \\
\hline & & CV (\%) & 9,69 & 3,02 & 7,06 & 9,76 & 3,09 & 5,69 \\
\hline
\end{tabular}

\subsubsection{Paredes de alvenaria}

As diversas possibilidades para calcular o módulo de deformação nem sempre convergem a resultados próximos. A Tabela 6.10 apresenta os resultados da determinação do módulo de deformação sobre diferentes critérios, do exemplo da Figura 6.4, que indica a curva tensão-deformação de uma das paredes sem revestimento da série $\mathrm{N}$.

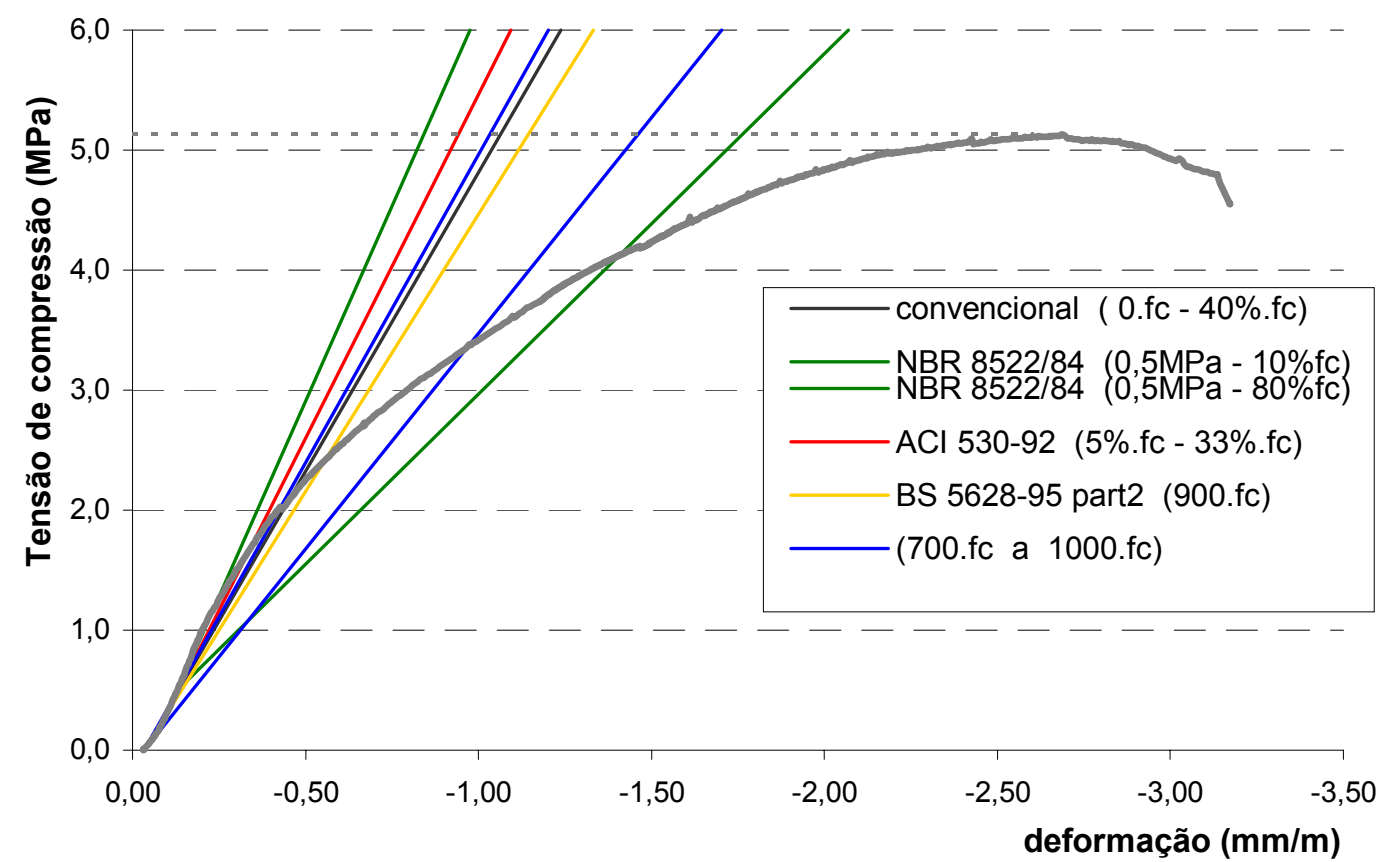

Figura 6.4 - Variação do módulo de deformação 
Tabela 6.10 - Resultados dos diferentes módulos de deformação para mesma curva tensão-deformação

\begin{tabular}{cc||c}
\hline \hline \multicolumn{2}{c|}{ critério } & $E_{\text {pam }}(\mathrm{MPa})$ \\
\hline \hline convencional & $0 \%$ a $40 \%$ de $\mathrm{f}_{\text {alv }}$ & 4.984 \\
\hline \multirow{2}{*}{$\mathrm{NBR} 8522 / 84$} & $0,5 \mathrm{MPa}$ a $10 \%$ de $\mathrm{f}_{\text {alv }}$ & 6.500 \\
& $0,5 \mathrm{MPa}$ a $80 \%$ de $\mathrm{f}_{\text {alv }}$ & 2.838 \\
\hline $\mathrm{ACl} 530-92$ & $5 \%$ a 33\% de falv & 5.727 \\
\hline BS 5628-95 & $900 . \mathrm{f}_{\text {alv }}$ & 4.617 \\
\hline \multirow{2}{*}{ outros } & $700 \mathrm{f}_{\text {alv }}$ & 3.591 \\
& $1000 . \mathrm{f}_{\text {alv }}$ & 5.130 \\
\hline \hline
\end{tabular}

Sendo assim, é difícil afirmar qual desses critérios resulta no módulo de deformação real. Conforme citado no Capítulo 2, o critério exposto pelo ACI 530-92 é o mais indicado para análise experimental, devido à consideração do efeito de acomodação do capeamento e do intervalo relativamente satisfatório que garante ser inferior ao módulo tangente.

As paredes de alvenaria apresentaram comportamentos distintos, em função da argamassa de assentamento e de revestimento. A Tabela 6.11 apresenta os resultados dos módulos de deformação secantes médios das paredes $\left(\mathrm{E}_{\mathrm{pam}}\right)$, determinados pelo mesmo critério dos blocos de concreto (equação 2.13).

Tabela 6.11 - Módulos de deformação das paredes, em função do tipo de agregado presente nas argamassas

\begin{tabular}{c||c|r}
\hline \hline \multicolumn{1}{c||}{ parede } \\
série & $\mathrm{E}_{\text {pam }}(\mathrm{MPa})$ & $\mathrm{CV}(\%)$ \\
\hline \hline $\mathrm{R}$ & 4.819 & 8,7 \\
$\mathrm{RN}$ & 6.113 & 1,4 \\
$\mathrm{RR}$ & 8.318 & 3,2 \\
\hline $\mathrm{N}$ & 5.147 & 8,9 \\
$\mathrm{NN}$ & 8.692 & 13,5 \\
$\mathrm{NR}$ & 7.029 & 14,8 \\
\hline $\mathrm{N}^{*}$ & 6.440 & 2,3 \\
$\mathrm{~N}^{* *}$ & 8.693 & - \\
\hline \hline${ }^{*} \mathrm{f}_{\mathrm{bk}}=9,0 \mathrm{MPa}$ (JUSTE, 2001) \\
$* * \mathrm{f}_{\mathrm{bk}}=20,0 \mathrm{MPa}$ (JUSTE, 2001)
\end{tabular}

Ao se analisar as paredes assentadas com argamassa contendo agregados naturais da tabela acima, juntamente com a Tabela 6.3, percebe-se que as paredes possuem a mesma resistência à compressão, porém o revestimento influi na rigidez.

A Tabela 6.12 relaciona os módulos de deformação das paredes estudadas, possibilitando analisar o desempenho do agregado presente na argamassa de assentamento, e a influência do tipo de argamassa de revestimento. Ao comparar 
os módulos de deformação das paredes assentadas com a mesma argamassa reciclada, o ganho de rigidez da parede $\mathrm{RR}$ que substitui a $\mathrm{RN}$, é de $36 \%$, entretanto a relação entre revestimentos reciclados com diferentes argamassas de assentamento, resulta em $18 \%$ de acréscimo na rigidez entre a RR sobre a NR.

Tabela 6.12 - Relação entre os módulos de deformação das paredes em função do tipo de agregado presente na argamassa

\begin{tabular}{c||c|c|c|c|c|c}
\hline \multicolumn{1}{c||}{$\mathrm{E}_{\mathrm{X}} / \mathrm{E}_{\mathrm{Y}}$} & \multicolumn{5}{c}{$\mathrm{X}$} \\
& $\mathrm{R}$ & $\mathrm{RN}$ & $\mathrm{RR}$ & $\mathrm{N}$ & $\mathrm{NN}$ & $\mathrm{NR}$ \\
\hline \hline $\mathrm{R}$ & 1,00 & 1,27 & 1,73 & 1,07 & 1,80 & 1,46 \\
$\mathrm{RN}$ & 0,79 & 1,00 & 1,36 & 0,84 & 1,42 & 1,15 \\
$\mathrm{YR}$ & 0,58 & 0,73 & 1,00 & 0,62 & 1,04 & 0,84 \\
\hline $\mathrm{N}$ & 0,94 & 1,19 & 1,62 & 1,00 & 1,69 & 1,37 \\
$\mathrm{NN}$ & 0,55 & 0,70 & 0,96 & 0,59 & 1,00 & 0,81 \\
$\mathrm{NR}$ & 0,69 & 0,87 & 1,18 & 0,73 & 1,24 & 1,00 \\
\hline \hline
\end{tabular}

A seguir, apresentam-se na Figura 6.5, as curvas médias, das paredes, ajustadas nos diagramas tensão-deformação, referentes a $80 \%$ da tensão última.

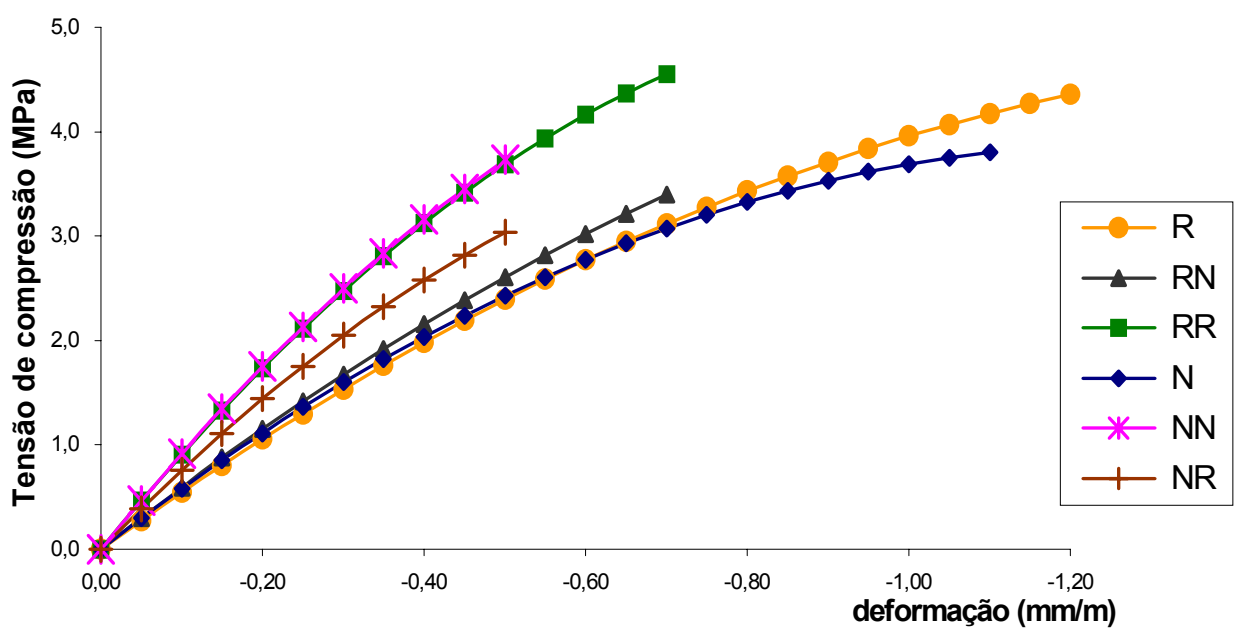

Figura 6.5 - Diagramas tensão-deformação das paredes com e sem revestimento

Colocando-se os valores dos módulos das paredes de forma decrescente, verifica-se que as paredes assentadas e revestidas com o mesmo tipo de argamassa, possuem os maiores módulos de deformação, e que a ausência de revestimento reduz tornando-a menos rígida. Além disto, as argamassas contendo agregado reciclado reduzem a rigidez da parede de alvenaria. A Figura 6.6 apresenta a ruptura típica de paredes revestidas, cuja diferença básica no modo de ruptura dos blocos de alvenaria com as paredes e prismas é a esbeltez. 


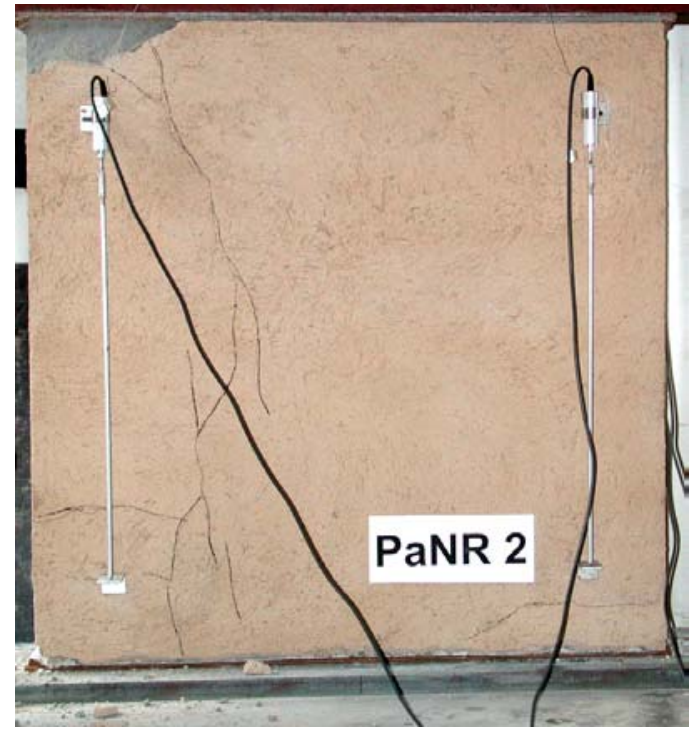

a) superfície revestida

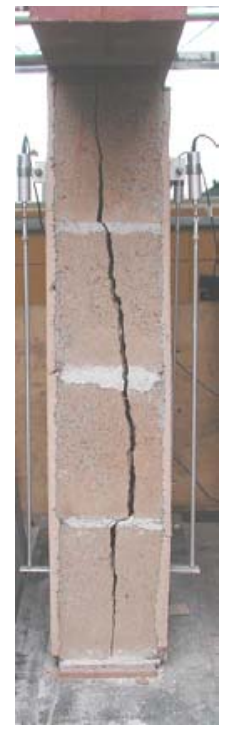

b) perfil

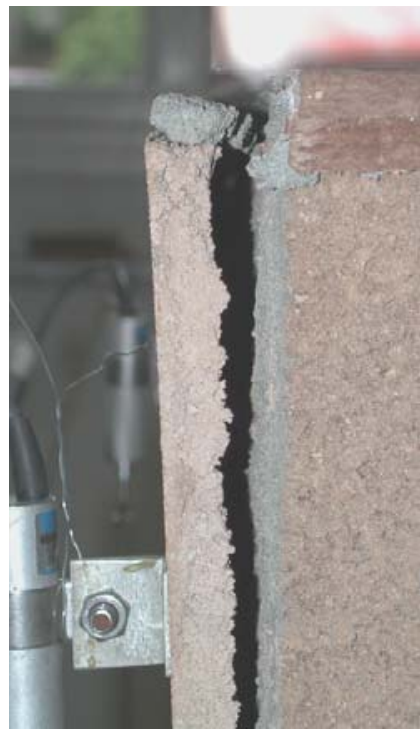

c) descolamento

Figura 6.6 - Fissuração típica das paredes revestidas

Durante a realização dos ensaios, as paredes que possuíam revestimento, sofreram descolamento em alguns pontos (Figura 6.6c). Como a argamassa é um material com baixo módulo de deformação se comparada ao bloco de alvenaria, e portanto mais deformável, quando as tensões de compressão são transmitidas do bloco ao revestimento, ela reage no sentido contrário ao solicitado. Desta forma, quando a solicitação for superior à resistência de aderência à tração, em determinado ponto, este sofre descolamento do substrato. No entanto, caso a aderência seja elevada em torno do mesmo ponto, ou seja, o ponto fraco esteja delimitado, haverá então um estado de tensão multiaxial, cuja deformação ocorrerá na superfície não confinada, ou seja, para o lado externo do revestimento, caracterizando-se pelo efeito de estufamento do revestimento. Porém, este tipo de descolamento ocorre quando não há abertura de fissuras na superfície transversal da parede.

Um fato importante a considerar, é que o revestimento aplicado possa ter bloqueado a penetração de dióxido de carbono, impedido o processo de carbonatação da argamassa de assentamento em uma direção. 


\subsection{Ensaios $\underline{\text { em }} \underline{\operatorname{argamassas}}$}

Para esclarecer melhor os comportamentos das argamassas utilizadas nas paredes, bem como o impedimento do processo de carbonatação em uma direção da argamassa de assentamento, procurou-se obter os principais parâmetros das argamassas: resistência à compressão, resistência à aderência à tração, módulo de deformação e desenvolvimento do processo de carbonatação até a idade de romper os prismas e paredes.

\subsubsection{Determinação do módulo de deformação da argamassa}

Para completar a análise do comportamento das argamassas contidas nos painéis de alvenaria quando carregadas axialmente, determinaram-se os módulos de deformaçãos secante das argamassas contendo agregado natural $(N)$ e reciclado $(R)$. Este ensaio foi baseado pela NBR 8522/84, porém recorreu-se a NBR 5739/80 para reduzir a velocidade de carregamento. A Figura 6.7 expõe as curvas médias de tensão-deformação dos corpos-de-prova cilíndricos $15 \times 30 \mathrm{~cm}$ das argamassas, ajustadas à parábola correspondente a $80 \%$ da tensão última $\left(\mathrm{f}_{\mathrm{am}}\right)$.

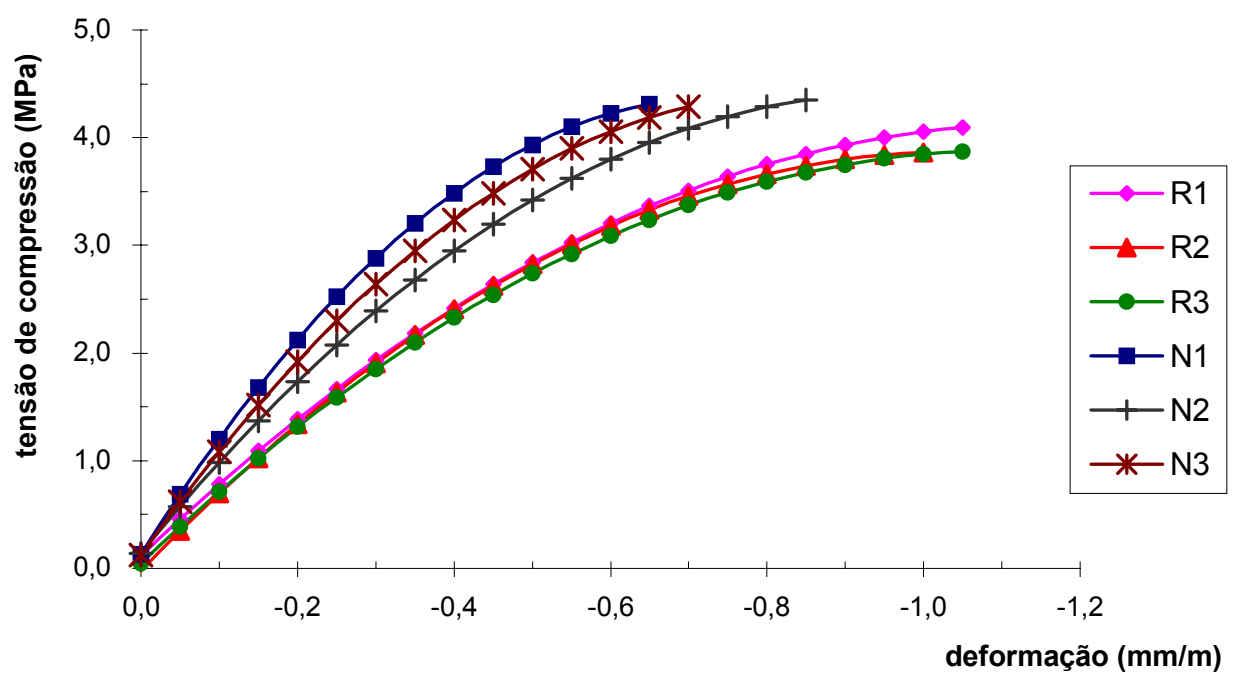

Figura 6.7 - Diagramas tensão-deformação das argamassas

Como o comportamento das argamassas é resultante dos agregados utilizados, a rigidez dos agregados naturais proporcionou à respectiva argamassa, menor deformação comparada aos agregados reciclados. Os resultados médios dos 
módulos de deformação das argamassa $\left(E_{a m}\right)$ apresentam-se na Tabela 6.13, determinados pela mesma metodologia proposta às paredes e aos blocos de alvenaria (equação 2.2).

Tabela 6.13 - Módulo de deformação das argamassas

\begin{tabular}{cc||cc|cr}
\hline \multicolumn{2}{l}{ tipo de argamassa } & $\mathrm{f}_{\mathrm{am}}(\mathrm{MPa})$ & $\mathrm{CV}(\%)$ & $\mathrm{E}_{\mathrm{am}}(\mathrm{MPa})$ & $\mathrm{CV}(\%)$ \\
\hline \hline III pobre & $\mathrm{R}$ & 4,90 & 3,33 & 6.244 & 3,66 \\
III pobre & $\mathrm{N}$ & 5,38 & 0,00 & 9.019 & 12,81 \\
\hline II média & $\mathrm{N}^{*}$ & 6,47 & 1,99 & 9.796 & 1,05 \\
III pobre & $\mathrm{N}^{*}$ & 4,20 & 1,64 & 7.598 & 4,73 \\
\hline \hline
\end{tabular}

* JUSTE, 2001

Com o aumento do módulo de deformação das argamassas utilizadas ao assentamento dos blocos de alvenaria, comparada às argamassas utilizadas neste trabalho, JUSTE (2001) obteve maior rigidez em suas paredes, devido ao fato da rigidez de um determinado elemento ser dependente da somatória de rigidez de seus componentes. Dessa forma, explica-se o fato das paredes que possuem revestimentos apresentam maior módulo de deformação se comparadas às sem revestimento.

Analisando os módulos de deformação das paredes revestidas, verifica-se que as paredes assentadas e revestidas com mesma argamassa (RR e NN), possuem maior rigidez se comparadas às RN e NR. A hipótese é que distintas argamassas possuem comportamentos diferentes. Entretanto, ao se analisarem as paredes com distintas argamassas no assentamento e revestimento, verifica-se que o módulo de deformação da argamassa de assentamento é a principal responsável pela rigidez global do elemento.

Ao fazer a mesma análise realizada por OLIVEIRA (2001), em que se compara a curva tensão-deformação média das paredes sem revestimento e das argamassas, percebe-se que a argamassa de assentamento da parede da série $\mathrm{R}$ rompe antes da ruína da parede (Figura 6.8). No entanto, em relação à parede da série N, o mesmo não ocorre, pois a argamassa rompe na mesma tensão que a parede. Esclarece-se que as curvas médias das paredes expostas possuem linearidade até a deformação de $2 \mathrm{~mm} / \mathrm{m}$, cujos maiores valores representam as tensões últimas de ruptura. 


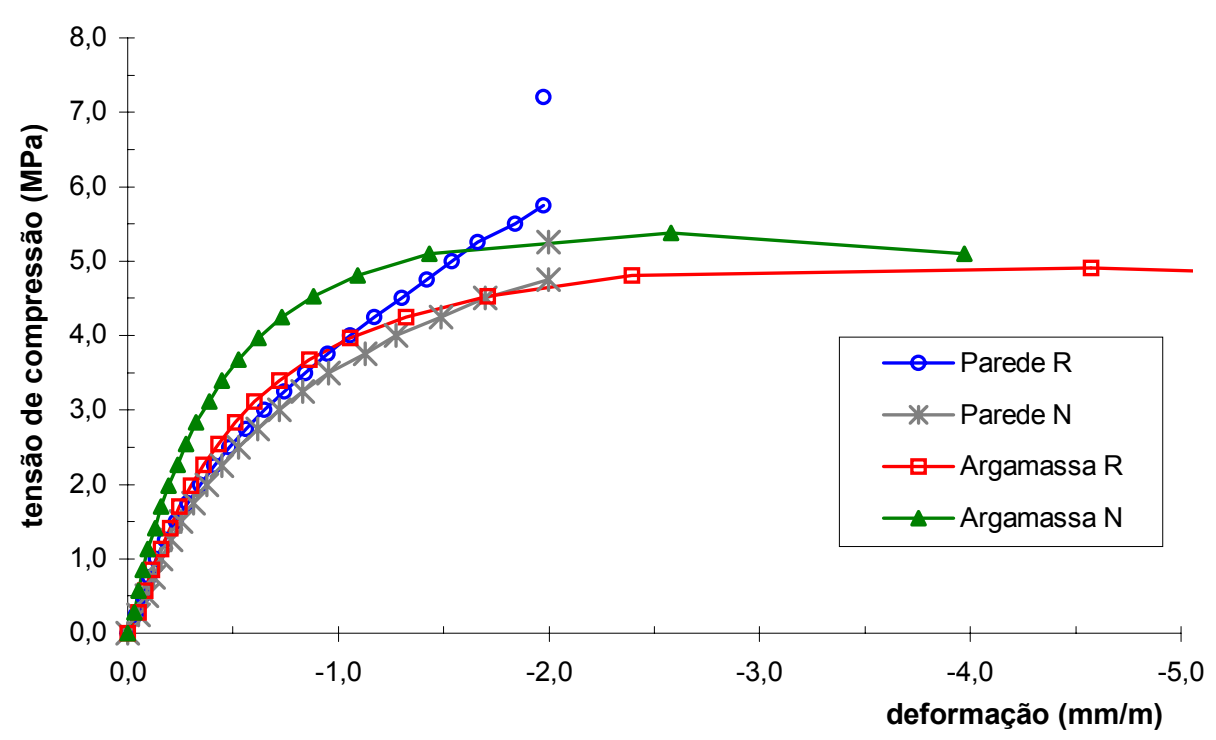

Figura 6.8 - Curva tensão-deformação das argamassas e das paredes sem revestimentos

\subsubsection{Resistência de aderência à tração do revestimento de argamassa}

A taxa de carregamento, para corpos-de-prova de seção circular de $50 \mathrm{~mm}$ de diâmetro, deve ser aplicada em função da tensão de resistência de aderência, conforme Tabela 6.14, segundo a NBR 13528/95. Como não havia estudo anterior de argamassas contendo agregados reciclados, adotou-se a taxa de $50 \mathrm{~N} / \mathrm{s}$.

Tabela 6.14 - Taxas de carregamento para o ensaio de aderência

\begin{tabular}{c||c|c|c|c}
\hline \hline resistência de aderência (MPa) & $\mathrm{Ra}<0,20$ & $0,20<\mathrm{Ra}<0,50$ & $0,50<\mathrm{Ra}<1,00$ & $\mathrm{Ra}>1,00$ \\
\hline \hline taxa de carregamento (N/s) & 5 & 25 & 100 & 200 \\
\hline \hline
\end{tabular}

FONTE: NBR 13528/95

A Figura 6.9 expõe a execução do ensaio de aderência por tração do revestimento de argamassa. Após instalado e nivelado o equipamento, aplica-se o carregamento de areia no recipiente sustentado pelo dispositivo, que transfere-o à pastilha aderida ao corpo-de-prova. Este ensaio é caracterizado pela queda do dispositivo ao perder a sustentação oriunda do corpo-de-prova de argamassa, que rompe por tração ou por descolamento do substrato, quando a solicitação exigida for superior à força que a argamassa pode resistir. 


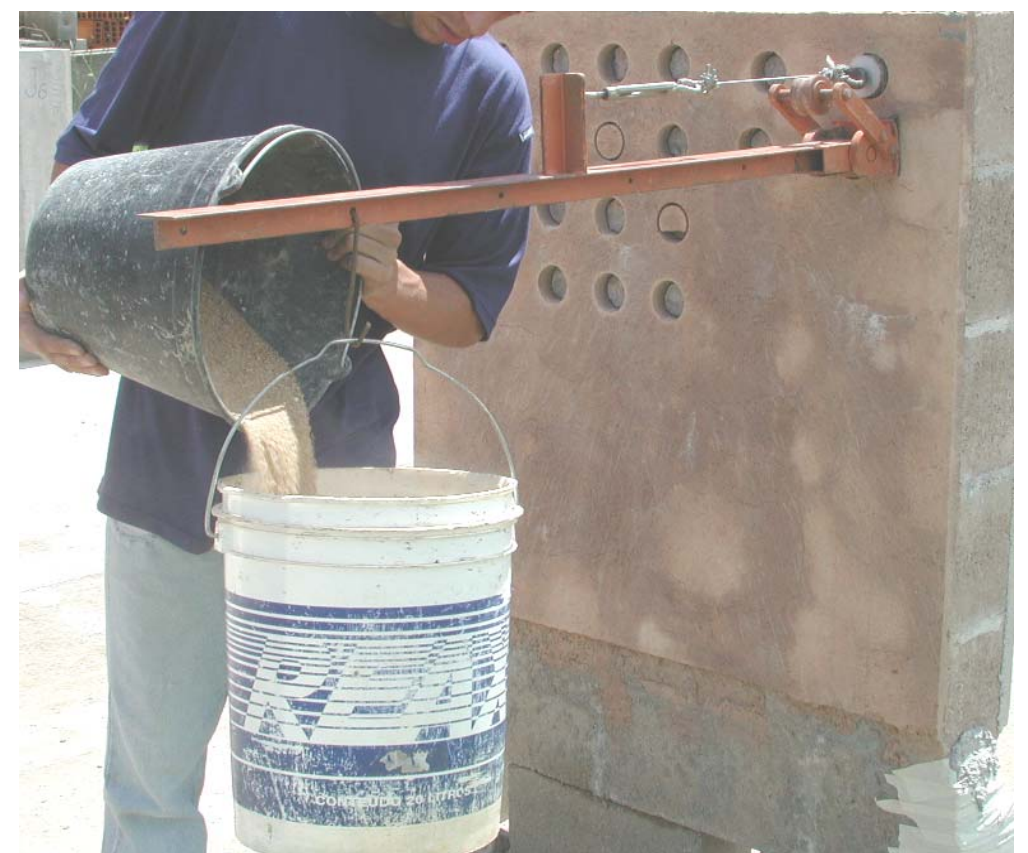

Figura 6.9 - Execução do ensaio de aderência da argamassa

A Tabela 6.15 apresenta os resultados dos ensaios de determinação da resistência à compressão das argamassas $\left(\mathrm{f}_{\mathrm{am}}\right)$ de assentamento e de revestimento de cada tipo de parede.

Tabela 6.15-Resistência de compressão das argamassas, referente ao ensaio de aderência à tração das argamassas de revestimento

\begin{tabular}{c|c||c|c|c}
\hline \hline função da argamassa & série & idade (dias) & $\mathrm{f}_{\text {am }}(\mathrm{MPa})$ & $\mathrm{CV}(\%)$ \\
\hline \hline \multirow{2}{*}{ assentamento } & NN e NR & 35 & 7,42 & 3,1 \\
& RN e RR & 35 & 7,98 & 5,4 \\
\hline \multirow{3}{*}{ revestimento } & NN & 33 & 5,83 & 3,1 \\
& NR & 33 & 7,97 & 7,7 \\
\cline { 2 - 5 } & RN & 33 & 7,77 & 15,3 \\
& RR & 33 & 9,55 & 21,5 \\
\hline \hline
\end{tabular}

A Figura 6.10 compara a resistência de aderência à tração $(\mathrm{Ra})$ dos revestimentos em função do local em que ocorreu a ruptura, cujos valores foram determinados pela média aritmética de 10 corpos-de-prova. Nos revestimentos tipo $\mathrm{RN}$, os corpos-de-prova em que a aderência do substrato ao revestimento foi elevada, romperam-se por tração direta. As amostras de cada corpo-de-prova estão expostas no Anexo C. 


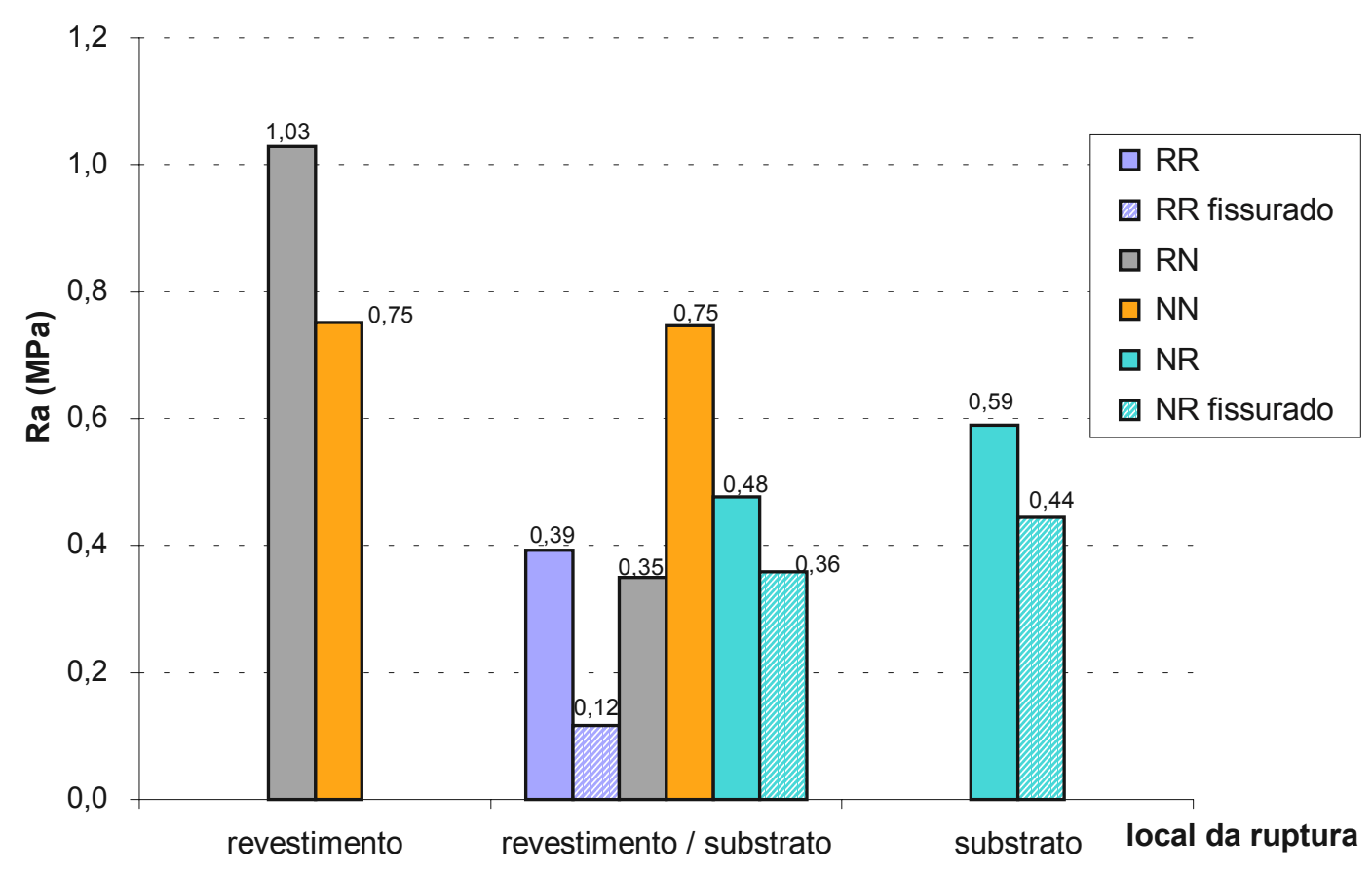

Figura 6.10 - Comparativo das resistências de aderência à tração

Conforme se verifica na Figura 6.10, as amostras que resultaram na maior resistência de aderência à tração, foram os revestimentos contendo agregado natural ( $\mathrm{RN}$ e $\mathrm{NN})$. Entretanto, as amostras da parede $\mathrm{RN}$ resultam em revestimentos com grande variação na resistência em distintos locais de ruptura.

As amostras com revestimentos contendo agregados reciclados, conforme mencionado no Capítulo 5, resultaram em fissuras provenientes de retração. Analisando-se as séries RR e NR, as amostras fissuradas apresentaram queda de resistência. Em particular, as amostras de RR com e sem fissuras, caracterizam-se por apenas um local de ruptura: aderência entre o chapisco e a argamassa de revestimento. Como o módulo de deformação das argamassas contendo agregados reciclados, determinados no item anterior, foram inferiores aos agregados naturais, evidencia-se que o formato dos grãos do agregado reciclado prejudica a compacidade da argamassa. Além disto, as argamassas necessitam de maior quantidade de água de amassamento para apresentarem mesma consistência que as argamassas com agregados naturais. Logo, a quantidade de vazios, provenientes da hidratação das partículas de cimento, será maior, resultando na redução de carregamento aplicado. 
Porém a queda de resistência não é apenas proveniente do revestimento. Houve a influência da argamassa de assentamento na aderência do revestimento, pois a fração miúda dos agregados reciclados, presentes na argamassa de assentamento e revestimento, é constituída basicamente por silte, saibro, argila e substancias nocivas, existentes no material cimentício e na cerâmica vermelha.

Além desta, outras condicionantes influem na queda de resistência de aderência do agregado reciclado:

a ) agregado natural possui maior coeficiente de forma quando comparados às partículas lamelares e angulares dos agregados reciclados. Quando produzida uma argamassa com este material, haverá um menor volume de vazios, conseqüentemente será menos frágil;

b ) para a mesma argamassa de revestimento, a absorção de água será maior no assentamento com agregado reciclado que com agregado natural. Dessa forma, haverá um gradiente de absorção do revestimento para as fiadas de argamassa contendo agregado reciclado, retirando toda a água de adsorção envolvida pelo agregado, resultando em perda de aderência na superfície de contato do substrato;

c ) a quantidade de água adsorvida pelo agregado acarreta no aumento de seu volume. Analisando o ensaio de inchamento dos agregados, percebe-se que o agregado reciclado possui maior umidade crítica para mesmo coeficiente de inchamento. Isto significa que, para obter o mesmo volume inchado do agregado natural, deve-se aumentar a quantidade de água. Entretanto, este acréscimo pode provocar expansão da argamassa, e quando exposta ao sol, a perda de água será elevada, provocando fissuras de retração por secagem;

d) o material pode sofrer grandes variações de composição e de distribuição granulométrica, produzindo revestimentos com ampla variação de desempenho.

Mas então, por que os agregados reciclados resultam em resistência à compressão maior que os naturais e menor quando analisados na resistência de aderência à tração? 
Dentre os vários fatores que influenciam na inversão de resistência, dois são principais:

a ) Os revestimentos e os corpos-de-prova cilíndricos, destinados à determinação da resistência à compressão, permaneceram sob diferentes condições climáticas. Enquanto os revestimentos das paredes expunham-se ao sol, vento, temperatura, a possibilidade e ocorrência de retração foram elevadas, comparadas aos corpos-deprova cilíndricos que permaneceram na câmara úmida, até a idade de determinar a resistência de aderência;

b ) Não se pode comparar corpos-de-prova com diferentes energias de adensamento. Enquanto os revestimentos são adensados apenas com o lançamento da argamassa ao substrato, as amostras cilíndricas são adensadas com soquete metálico. A dificuldade de aplicar a argamassa no sentido horizontal, é muito maior que a dos corpos-de-prova cilíndricos. Enquanto que os corpos-de-prova cilíndricos das argamassas possuem determinado teor de ar incorporado, o adensamento com soquete pode expulsar pequena porcentagem do ar presente no mesmo, enquanto que a presença de rugosidade do chapisco pode dificultar a penetração dos grãos envolvidos pelas partículas de cimento, resultando numa fina camada de ar existente entre o chapisco e o revestimento, o que impede a aderência ao substrato.

A Figura 6.11 e Figura 6. 12, expõem as paredes assentadas com argamassa de agregado natural e reciclado, respectivamente, com e sem fissuração nas argamassas de revestimento contendo agregado reciclado. Verifica-se visualmente, que o chapisco em contato com a argamassa de revestimento, independente da natureza da argamassa de assentamento, indica que a principal queda de resistência de aderência à tração é proveniente da aderência mecânica, uma vez que ambas as argamassas possuem os mesmos traços. 

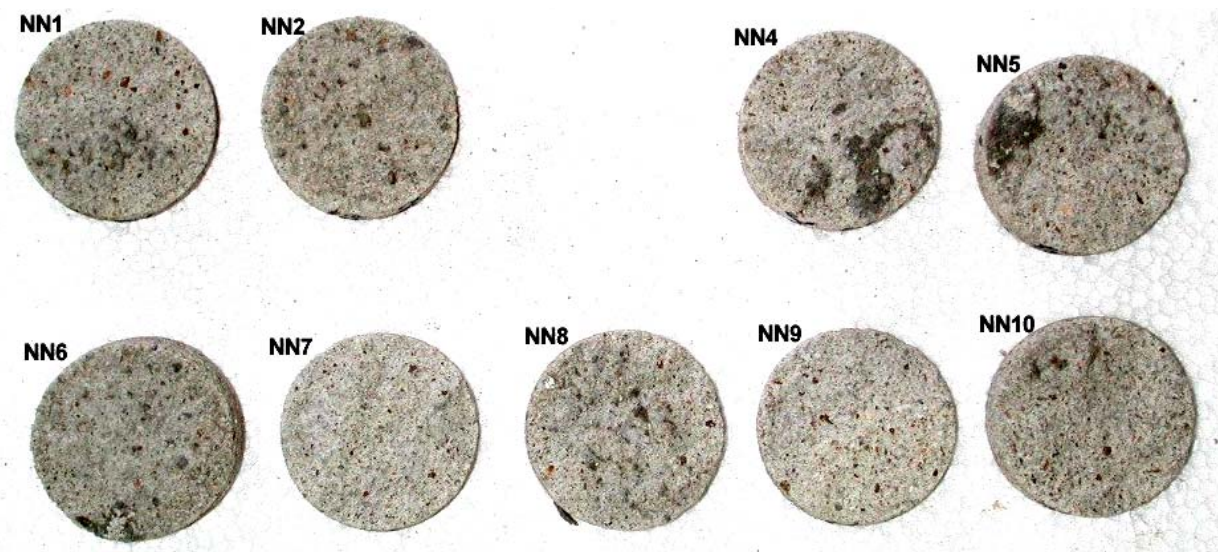

NN
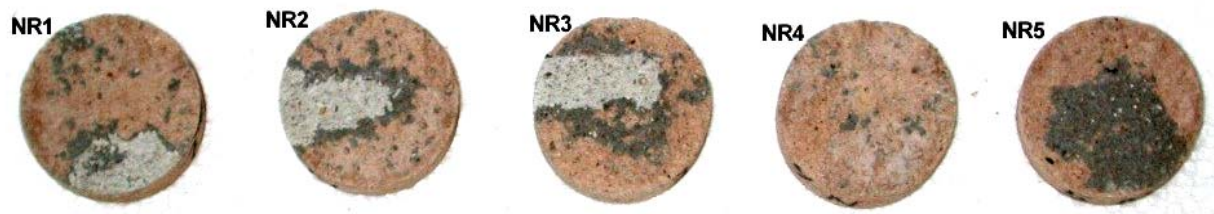

NR
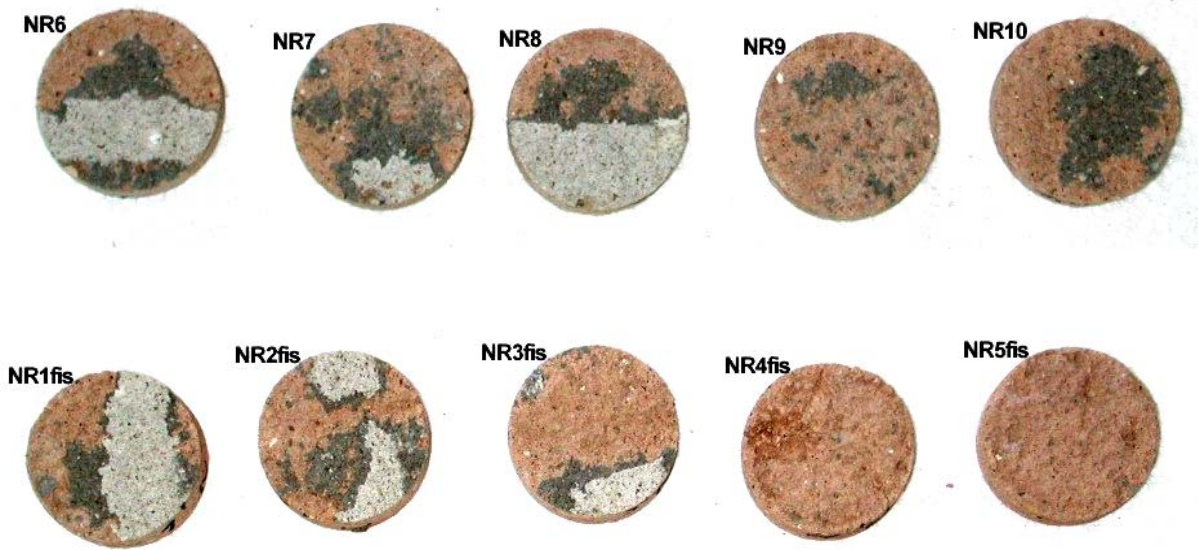

NR fis
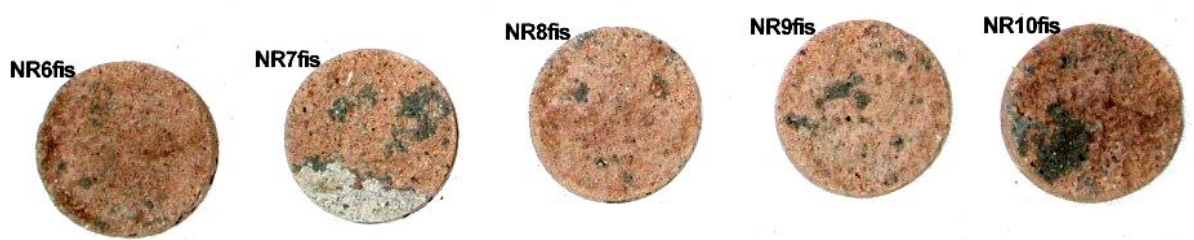

Figura 6.11 - Aderência entre chapisco e argamassa de revestimento, em parede de bloco de concreto com argamassa de assentamento contendo agregado natural 


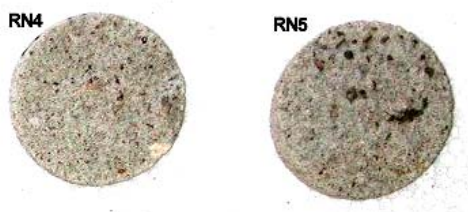

RN
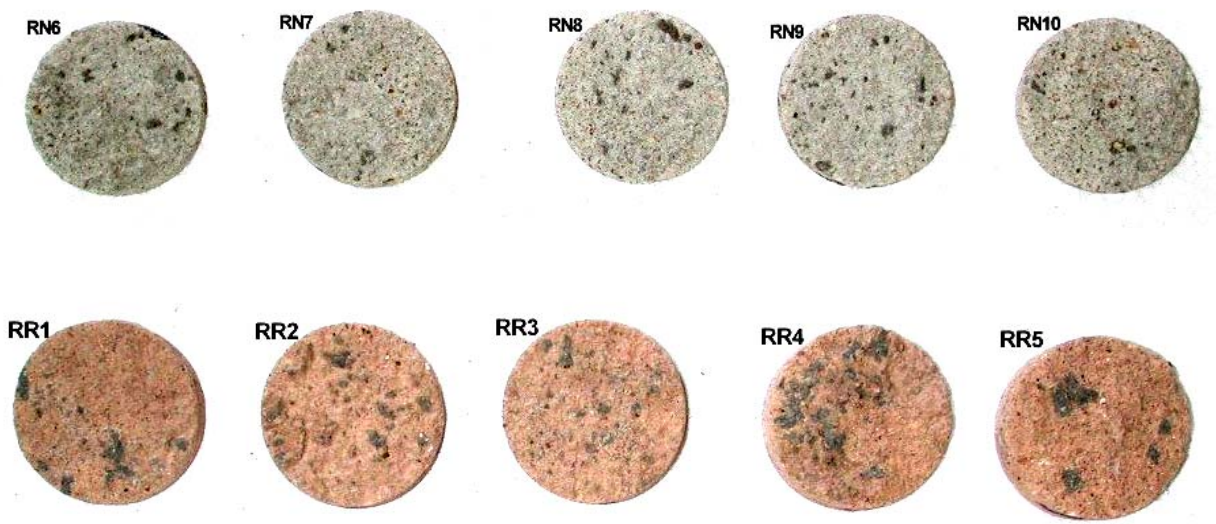

$\mathrm{RR}$
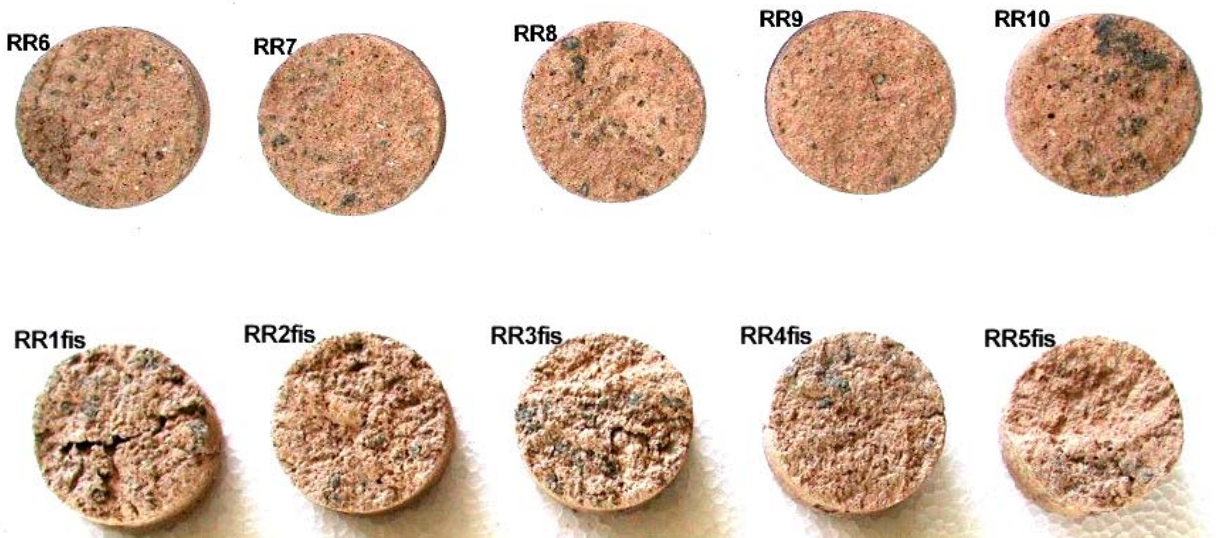

RR fis
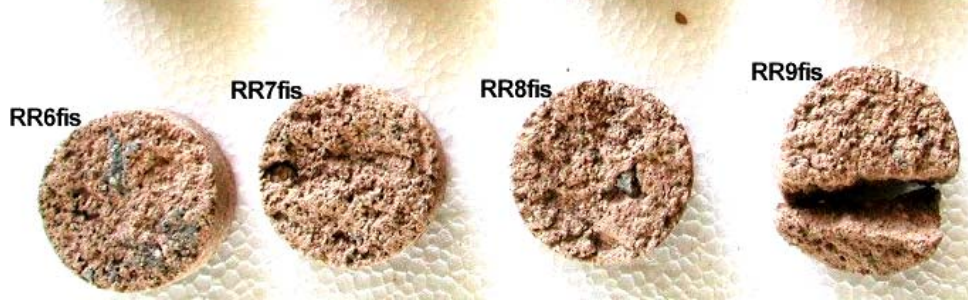

Figura 6.12 - Aderência entre chapisco e argamassa de revestimento, em parede de bloco de concreto com argamassa de assentamento contendo agregado reciclado

Dessa forma, com exceção das amostras de RR fissurado, todos os demais revestimentos podem ser utilizados em qualquer tipo de acabamento, pois segundo a NBR 13749/95, o revestimento deve possuir a resistência mínima de aderência à tração, conforme citado na Tabela 6.16 . 
Tabela 6.16- Espessuras admissíveis de revestimentos e limites de resistência de aderência à tração para emboço com camada única

\begin{tabular}{c|c|c|c}
\hline \hline local & espessura $(\mathrm{mm})$ & acabamento & Ra (MPa) \\
\hline \hline parede interna & $5 \leq \mathrm{e} \leq 20$ & $\begin{array}{c}\text { pintura ou base para reboco } \\
\text { cerâmica ou laminado }\end{array}$ & $\begin{array}{c}\geq 0,20 \\
\geq 0,30\end{array}$ \\
\hline parede externa & $20 \leq \mathrm{e} \leq 30$ & $\begin{array}{c}\text { pintura ou base para reboco } \\
\text { cerâmica }\end{array}$ & $\begin{array}{c}\geq 0,30 \\
\geq 0,30\end{array}$ \\
\hline teto & $\mathrm{e} \leq 20$ & - & $\geq 0,20$ \\
\hline \hline \multicolumn{3}{c}{ FONTE: NBR 13749/96 }
\end{tabular}

\subsubsection{Análise da carbonatação}

Devido à não verificação da profundidade de carbonatação das argamassas, determinadas na confecção anterior dos prismas e paredes, a mesma foi determinada pela média aritmética dos revestimentos de mesma natureza, sendo que cada revestimento possuía 36 leituras aos 10 e 19 dias de idade de cada prisma novo revestido (Anexo C), e a profundidade determinada aos 248 dias é proveniente dos revestimentos das paredes utilizadas no ensaio de resistência da aderência. A Figura 6.13 apresenta a curva de desenvolvimento da profundidade de carbonatação das argamassas utilizadas. A parte representada com linha pontilhada representa a estimativa aos 248 dias de idade.

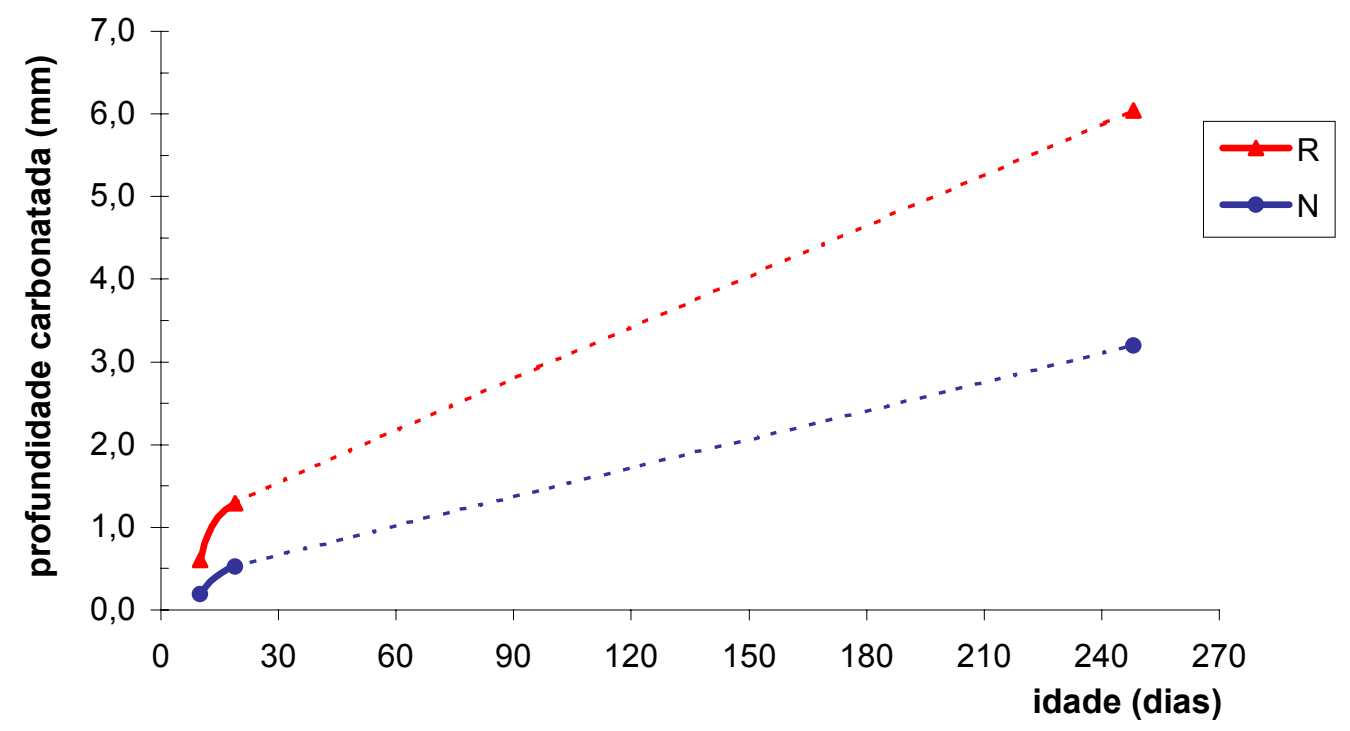

Figura 6.13 - Profundidade média de carbonatação das argamassas 
Dessa forma, verifica-se que a argamassa mais porosa apresenta maior taxa de carbonatação que a argamassa contendo agregados naturais. Este fato já era estimado, devido à argamassa com agregados reciclados possuir menor massa específica e maior quantidade de água de amassamento.

O baixo consumo de cimento das argamassas (aproximadamente $185 \mathrm{~kg} / \mathrm{m}^{3}$ ), possibilitou obter profundidades de carbonatação muito distintas, contrariando os resultados obtidos por BARRA \& VAZQUEZ (1997). Contudo, esta discordância pode ser resultante da natureza dos agregados reciclados.

Retornando à análise da perda de resistência das paredes revestidas, pode-se concluir que a aplicação do revestimento, nas primeiras idades da argamassa de assentamento, impediu o processo de carbonatação em uma das direções. Mesmo que as paredes possuam revestimentos, o principal fator que influencia na resistência à compressão e à rigidez, é a argamassa de assentamento. Isto significa que o revestimento somente deve ser aplicado após iniciar o processo de carbonatação do assentamento, uma vez que o processo somente é interrompido quando está saturado com água.

Verificou-se também, a presença de carbonato de cálcio lixiviado em ambos os tipos de revestimento (Figura 6.14). Porém, como a argamassa contendo agregados naturais possui maior compacidade, o respectivo revestimento apresenta o composto químico em menor quantidade, e quase imperceptível a "olho nu".

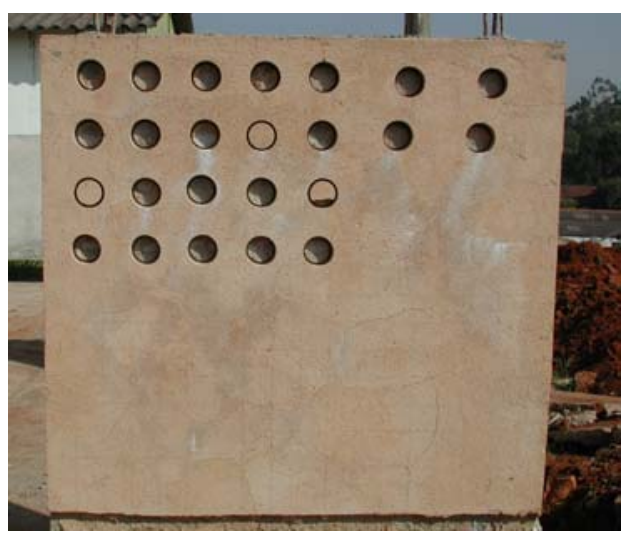

a) revestimento com agregado reciclado

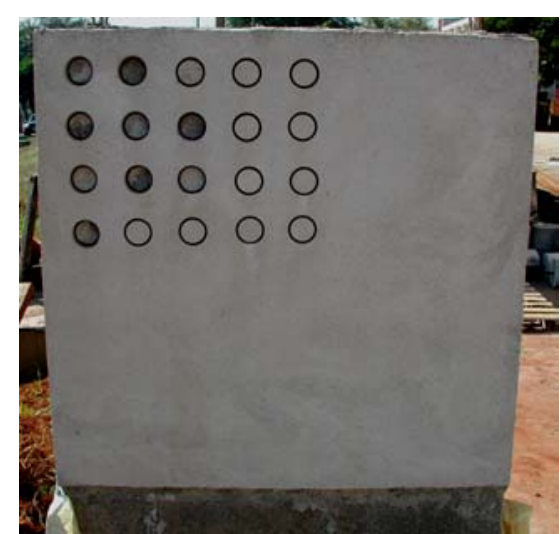

b) revestimento com agregado natural

Figura 6.14-Presença de carbonato de cálcio lixiviado das argamassas de revestimento 
Ao se determinar a profundidade de carbonatação em amostras de blocos de concreto, verificou-se que a desuniformidade (Figura 6.15) mostra as diferentes profundidades de carbonatação de duas amostras de argamassas de revestimento. A parcela menos carbonatada (direita) é a parte mais espessa, respectiva à parte de baixo do bloco de concreto que sai da forma da vibro-prensa. Possivelmente, ao vibrar, uma parcela da pasta de cimento transferiu-se para a parte de baixo.

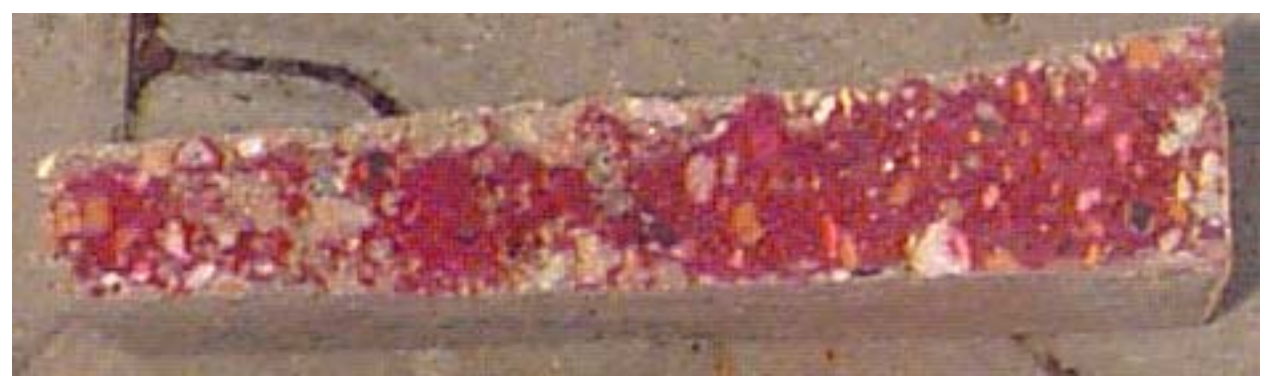

Figura 6.15 - Profundidade de carbonatação no bloco de concreto

Dessa forma, o bloco possui porosidade variada, em função da espessura dos septos. Entretanto, esta capacidade de carbonatar-se com mais facilidade é vantajosa, uma vez que resulta no preenchendo dos vazios, aumentando a compacidade, reduzindo a permeabilidade e aumentando a resistência da pasta carbonatada. 


\section{帚 7 CONCLUSÕES}

Conforme foi demonstrado nos capítulos anteriores, a utilização de agregados provenientes de RCD, possibilita substituir o agregado natural, resultando em produtos de boa qualidade. Entretanto, os métodos convencionais de caracterização física dos agregados são indispensáveis para o controle de qualidade dos agregados, pois, além de serem simples, possibilitam estabelecer o comportamento desta matéria-prima, constituindo bons detectores da heterogeneidade ou variabilidade.

A elevada variação das curvas granulométricas é significativa, pois pode prejudicar a resistência, a compacidade e a textura superficial na produção de blocos vazados de concreto para alvenaria. Em relação às massas específicas e unitárias, a grande variabilidade alteraria a massa do produto final e traria dificuldade de homogeneizar os agregados durante a mistura.

Entretanto, os atuais procedimentos para determinar a absorção de agregados porosos, não são eficazes. Como exemplo, ao deixar descansar a amostra de agregado reciclado, submersa em água, no frasco de Chapman, durante a determinação da absorção dos agregados reciclados, verificou-se que o nível de leitura varia, devido à elevada porosidade destes agregados. Desta forma, qualquer 
variação na absorção influenciaria na produção e comportamentos mecânicos de concretos e argamassas.

Os comentários foram baseados nos objetivos principais, como obter traços de concreto que resultassem na resistência característica mínima de blocos vazados com função estrutural, e na utilização de traços propostos de argamassas pela BS5628, sendo a quantidade de água estipulada pela consistência desejada. Estes e demais atos impostos, como a análise do comportamento das argamassas em grandes superfícies, mesmo quando expostas às intempéries atmosféricas como velocidade do vento e temperatura, possibilitaram aproximar o sistema produtivo "in loco" ao estudo realizado pertinente a esta pesquisa.

A seguir, apresentam-se as conclusões referentes aos seguintes aspectos:

$\underline{\text { Estudo de }} \underline{\text { traços de concreto }} \underline{\text { e }} \underline{\text { argamassa: }}$

a ) Os agregados reciclados apresentam alta capacidade de absorção de água, devido à alta porosidade característica dos RCD, oriunda da elevada quantidade de argamassa aderida aos agregados graúdos e da alta concentração de material cerâmico que constitui os agregados miúdos reciclados;

b ) Conforme demonstrado no capítulo 4, os critérios referentes à moldagem de corpos-de-prova cilíndricos da NBR 5738/94 são eficientes às misturas de consistência plástica. Entretanto, para representações de amostras de consistência seca, os corpos-de-prova adensados por processos semelhantes às vibro-prensas reduzem o teor de ar incorporado pela mistura, no estado fresco, reproduzindo o adensamento por compactação mecânica e por vibração;

c) Agregados miúdos de diferentes características, como absorção, massa específica e curva granulométrica, não devem ser substituídos um pelo outro sem um ajuste no proporcionamento entre agregados. Conforme os resultados de resistência à compressão de corpos-de-prova cilíndricos, expostos na Tabela 4.2, traços de concretos com agregados de naturezas distintas, podem apresentar diferentes resistências. Dentre as variáveis mencionadas, a maior capacidade de absorver água, dos agregados reciclados, significa que a quantidade de água 
utilizada não é o principal fator de redução da resistência devido à possibilidade de apresentar maior quantidade de poros na pasta de cimento, pois mantinha a consistência nula. Desta forma, supõe-se que esta redução de resistência seja oriunda de dois fatores: seu elevado volume de vazios resultante da falta de empacotamento entre agregados, e a elevada porosidade de cada grão de agregado.

\section{$\underline{\text { Blocos de concreto: }}$}

a ) A resistência à compressão característica dos blocos de concreto, resultou no acréscimo de $21,4 \%$ dos 7 aos 28 dias de idade, com 8,5MPa. Além do consumo de cimento de $212,66 \mathrm{~kg} / \mathrm{m}^{3}$, o bloco possui absorção de água de $8,1 \%$, inferior à máxima permitida de $10 \%$, conforme MB 3459/91;

b ) Quanto à deformação do bloco, o módulo de deformação obtido no prisma não apresentou coeficiente de variação significativo. Resultando em 10.810MPa, podese dizer que o bloco de concreto confeccionado com agregado reciclado deformou menos que o produzido com agregado natural, pois, segundo estudo apresentado por JUSTE (2001), blocos com resistência característica à compressão de 9,0MPa e $20,0 \mathrm{MPa}$ resultam nos módulos de deformação de $6.228 \mathrm{MPa}$ e $7.554 \mathrm{MPa}$, respectivamente. Supõe-se que esta maior rigidez do bloco produzido com agregado reciclado foi proveniente do maior consumo de cimento, pois conforme mencionado no Capítulo 2, os blocos de concreto produzidos com agregados naturais tem consumo de cimento não superior a $150 \mathrm{~kg} / \mathrm{m}^{3}$, inferior a $212,66 \mathrm{~kg} / \mathrm{m}^{3}$ referente ao bloco confeccionado com agregado de RCD;

\section{$\underline{\text { Prismas }} \underline{\text { e paredes de alvenaria: }}$}

a ) As resistências à compressão das argamassas foram adequados para os blocos de concreto. As relações de eficiência de resistência à compressão axial entre paredes, prismas e blocos de alvenaria, resultaram em excelentes resultados. Paredes assentadas com argamassa contendo agregado natural apresentaram resistências semelhantes, independente da existência de revestimento. No entanto, paredes 
revestidas e assentadas com agregados reciclados, resultaram em um decréscimo na resistência, porém superiores às assentadas com agregado natural. Esta queda de resistência nas paredes assentadas com argamassa contendo agregado reciclado, ocorre devido ao impedimento da argamassa de assentamento carbonatar-se em uma das direções. Quando as paredes e prismas foram ensaiados à compressão axial, dos 18 aos 24 dias de idade, a profundidade de carbonatação das argamassas com agregados reciclados apresentaram $1,29 \mathrm{~mm}$ de profundidade, enquanto que as com agregados naturais, $0,52 \mathrm{~mm}$;

b ) Os módulos de deformação das paredes, sem revestimento, resultaram em valores inferiores aos resultados obtidos por JUSTE (2001), cujos blocos de concreto utilizados foram produzidos apenas com agregados naturais e assentados com argamassa contendo agregados naturais. Isto já era esperado, pois, devido ao maior índice de vazios existentes em misturas contendo resíduos, além da alta porosidade dos agregados de $\mathrm{RCD}$, a rigidez do material é reduzida, resultando em um produto mais deformável, quando comparados às misturas com agregados naturais. As estimativas dos módulos de deformação das alvenarias, segundo a BS 5628-part 2 (1992), apresentam valores superiores e inferiores às paredes assentadas com argamassa reciclada e natural, respectivamente. No entanto, estudos citam uma variação de 700 a 1000 vezes a resistência à compressão axial das alvenarias. Neste caso, os módulos de deformação das paredes sem revestimento apresentaram coerência entre as estimativas;

c ) Ao se analisarem os valores dos módulos das paredes de forma decrescente, verificou-se que as paredes assentadas e revestidas com argamassa de mesma natureza possuem os maiores módulos de deformação, e que a ausência de revestimento reduz a rigidez da estrutura.

\section{Argamassas:}

a ) A resistência à compressão de corpos-de-prova cilíndricos das argamassas contendo agregados reciclados apresentaram resultados de $6,18 \mathrm{MPa}$ a $6,55 \mathrm{MPa}$ 
para assentamento e revestimento, superiores aos valores das argamassas contendo agregado natural, de 5,23MPa a $6,03 \mathrm{MPa}$, respectivamente;

b) Os corpos-de-prova que resultaram nas menores resistências de aderência, localizaram-se no perímetro da parede e nas fissuras dos revestimentos contendo agregados reciclados. As maiores resistências foram obtidas pelas paredes revestidas com argamassas contendo agregados naturais. Além disso, houve a influência da argamassa de assentamento na aderência do revestimento;

c ) As argamassas com agregados reciclados são mais deformáveis que as que contém agregado natural, com módulos de deformação de $6.244 \mathrm{MPa}$ e $9.019 \mathrm{MPa}$ respectivamente. Entretanto, a maior capacidade de deformar-se do revestimento argamassado com agregado reciclado dificulta a visualização da fissuração do elemento estrutural. Desta forma, a grande capacidade de deformar-se, possibilita à argamassa com agregado reciclado melhorar o comportamento da estrutura da alvenaria, pois mesmo possuindo maior resistência, também possui maior deformabilidade, resultando num melhor acomodamento da argamassa em relação ao elemento estrutural;

d ) A rigidez da junta vertical da argamassa influencia no módulo de deformação dos blocos vazados de alvenaria. Esta conclusão foi baseada na principal diferença na determinação do módulo de deformação dos blocos de concreto: a presença de juntas verticais de argamassa. Enquanto que o bloco de concreto com agregado reciclado possui módulo de deformação secante de $10.810 \mathrm{MPa}$, determinado no prisma, com baixa variação no valor do módulo de deformação com argamassas distintas, a presença de juntas verticais de argamassas com agregados naturais e reciclados aumentaram a rigidez dos blocos para $14.178 \mathrm{MPa}$ e $20.031 \mathrm{MPa}$, respectivamente. A explicação para este efeito é que uma parcela do carregamento é transferida e absorvida pelas fiadas de argamassa, resultando em um acréscimo na rigidez do elemento estrutural, pois as resistências à compressão das argamassas, estão diretamente proporcionais às resistências das paredes;

e ) Outro fato a se considerar, é a influência da profundidade de carbonatação das argamassas de assentamento. Como a argamassa com agregados reciclados possui 
maior taxa de carbonatação quando comparada às argamassas com agregados naturais, para mesmas idades, a argamassa de agregados naturais é menos resistente que a argamassa com agregados reciclados, em ambiente não saturado. Entretanto, esta argamassa não é recomendada para a fixação de caixilhos metálicos devido à facilidade de carbonatar-se e, conseqüentemente, oxidar-se.

\section{Continuidade $\underline{\grave{a}} \underline{\text { pesquisa }}$}

A utilização indiscriminada dos produtos que utilizam o agregado reciclado de RCD, baseados na confecção de corpos-de-prova cilíndricos para análise apenas da resistência à compressão e à tração, não garante que a resistência de aderência à tração seja diretamente proporcional, pois conforme demonstram os resultados utilizando argamassas com os agregados de RCD, é baixa a resistência de aderência à tração, além de ser elevada a freqüência do surgimento de fissuras. Dessa forma, quaisquer alterações na dosagem e procedimentos à produção dos blocos de concreto com agregados de RCD, que resultem na melhoria da resistência, deformação e absorção dos mesmos, serão de grande utilidade. Em relação ao desempenho mecânico, é evidente que a NBR 8522/84 não especifica o intervalo a ser considerado para determinar o módulo de deformação de blocos de concreto para alvenaria. Portanto, um estudo que proponha uma metodologia mais detalhada para determinar o módulo de deformação dos blocos, prismas e paredes de alvenaria, é de total importância para estimar o comportamento real das estruturas de alvenaria.

Além disso, com a preocupação à durabilidade dos elementos de alvenaria e das estruturas, torna-se indispensável à análise de manifestações nos concretos e argamassas. Como exemplo, propõem-se alterações nos traços de argamassas com agregados reciclados para apresentarem maiores resistências à tração no estado fresco, quando solicitadas às tensões de tração oriundas da retração, decorrentes da aplicação da argamassa de revestimento de obras em geral. Ao impedir o surgimento de fissuras dos revestimentos contendo agregados reciclados 
de RCD, é possível obter significativos acréscimos na resistência de aderência à tração dos revestimentos, pois as físsuras facilitam a lixiviação do carbonato de cálcio, principal responsável pelo preenchimento dos poros.

Em relação às argamassas, estudos futuros que possibilitem aumentar a resistência de aderência à tração dos revestimentos argamassados é de grande importância. Como já possuem maior resistência à compressão e maior capacidade de se deformarem que as argamassas com agregados naturais, é possível que a elevada aderência mecânica resulte na maior capacidade de absorver esforços e deformações de paredes de alvenaria. Contudo, demais análises referentes às argamassas de assentamento e revestimentos, como resistência de aderência ao cisalhamento, capilaridade, estanqueidade de ambos os revestimentos, resistência à tração dos blocos, retração por secagem dos blocos e argamassas, entre outros mais, são de grande importância para estabelecer parâmetros de projeto estrutural.

Conforme mencionado na revisão bibliográfica, o elemento estrutural de alvenaria, no caso o bloco, rompe por tração nos septos, e como a utilização de fibra tem como objetivo absorver parte da solicitação à tração, é de grande interesse estudar a adição de fibras sintéticas em blocos de concreto.

Em relação aos aditivos plastificantes e incorporadores de ar, é indispensável estudos futuros destes componentes químicos a serem incorporados em argamassas de revestimento contendo agregados reciclados, não apenas para estudar o comportamento estrutural da alvenaria com o aumento da resistência à aderência à tração do revestimento, mas principalmente, em relação ao comportamento térmicoacústico de painéis de alvenaria. 


\section{$\underline{\text { BIBLIOGRAFIA }}$}

ASSOCIAÇÃO BRASILEIRA DE NORMAS TÉCNICAS

— NBR 5738/1994 - Moldagem e cura de corpos-de-prova cilíndricos ou prismáticos.

_ NBR 5739/1980 - Ensaios de compressão de corpos-de-prova cilíndricos de concreto.

_ NBR 6136/1994 - Bloco vazado de concreto simples para alvenaria estrutural.

_ NBR 7173/1982 - Blocos vazados de concreto simples para alvenaria sem função estrutural.

_ NBR 7184/1982 - Blocos vazados de concreto simples para alvenaria sem função estrutural.

_ NBR 7186/1982 - Bloco vazado de concreto simples para alvenaria com função estrutural.

_ NBR 7216/1982 - Amostragem de agregados.

_ NBR 7222/1994 - Argamassa e concreto: Determinação da resistência à tração por compressão diametral de corpos-de-prova cilíndricos.

_ NBR 7223/1982 - Concreto: Determinação da consistência pelo abatimento de tronco de cone.

_ NBR 7251/1982 - Agregado em estado solto: Determinação da massa unitária.

_ NBR 7810/1983 - Agregado em estado compactado seco: determinação da massa unitária.

- NBR 8215/1983 - Prismas de blocos vazados de concreto simples para alvenaria estrutural - Preparo e ensaio à compressão. 
_ NBR 8522/1984 - Concreto: Determinação do módulo de deformação estática e diagrama tensão-deformação.

_ NBR 8949/1985 - Paredes de alvenaria estrutural - Ensaio à compressão simples.

— NBR 9776/1987 - Agregados: Determinação da massa específica de agregados miúdos por meio do frasco de Chapman.

_ NBR 9777/1987 - Agregados: Determinação da absorção de água em agregados miúdos.

— NBR 9937/1987 - Agregados: Determinação da absorção e da massa específica de agregado graúdo.

_ NBR 9941/1987 - Redução de amostra de campo de agregados para ensaios de laboratório.

_ NBR 10837/1985 - Cálculo de alvenaria estrutural de blocos vazados de concreto.

_ NBR 13276/1985 - Argamassa para assentamento de paredes e revestimentos de paredes e tetos - Determinação do teor de água para obtenção do índice de consistência-padrão.

_ NBR 13278/1995 - Argamassa para assentamento de paredes e revestimentos de paredes e tetos - Determinação da densidade da massa e do teor de ar incorporado.

- NBR 13279/1995 - Argamassa para assentamento de paredes e tetos Determinação da resistência à compressão.

- NBR 13528/1995 - Revestimentos de paredes e tetos de argamassas inorgânicas: Determinação da resistência de aderência à tração.

— NBR 13749/1995 - Revestimentos de paredes e tetos de argamassas inorgânicas: Especificação.

_ MB-116/1991 - Blocos vazados de concreto simples para alvenaria Determinação da resistência à compressão.

_ MB-215/1954 - Determinação do inchamento de agregados miúdos para concreto.

_ MB-3458/1991 - Blocos vazados de concreto para alvenaria - Retração por secagem.

- MB-3459/1991 - Blocos vazados de concreto simples para alvenaria Determinação da absorção de água, do teor de umidade e da área líquida.

Abreu, J.V. (2000). Produção de peças pré-moldadas de concreto. São Paulo, ABCP. / Curso sobre produção e controle de artefatos de cimento, Escola de Engenharia de São Carlos - USP, abr. 2000/.

Aïtcin, P.C. (2000). Concreto de alto desempenho. São Paulo, Pini. 
AMERICAN CONCRETE InSTITUTE (1992). ACI 211.3-75 - Standard practice for selecting proportions for no-slump concrete. Detroit, Michigan.

AMERICAN CONCRETE Institute (1992). ACI 308-92 - Standard practice for curing concrete. Detroit, Michigan.

AMERICAN CONCREte Institute (1992). ACI 530-92 - Building code requirements for masonry structures. Detroit, Michigan.

Angulo, S.C. (2000). Variabilidade de agregados graúdos de resíduos de construção e demolição. São Paulo. Dissertação (Mestrado) - Escola Politécnica, Universidade de São Paulo.

BArRA, M.; VAZquez, E. (1997). Particularidades do processo de carbonatação em concretos de agregado reciclado. In: IV CONGRESSO IBERO AMERICANO DE Patologia das Construções, VI Congresso de Controle de Qualidade. Porto Alegre-RS. Anais. CON PAT. UFRGS.

BAyeuX, P. (2000). Custos na parede. Téchne, São Paulo, n.48, p.32-37, set/out.

Bortoluzzo, C.W. (2000). Contribuição ao estudo do comportamento mecânico dos revestimentos de argamassa. São Carlos. Dissertação (Mestrado) - Escola de Engenharia de São Carlos, Universidade de São Paulo.

BRITISH StANDARDS InSTITUTION (1978). BS 5.628 - Code of practice for structural use of masonry. Part 1. Unreinforced masonry. London.

BRITISH StANDARDS InSTITUTION (1995). BS 5.628 - Code of practice for structural use of masonry. Part 2. Reinforced masonry. London.

Brito FILho, J.A., 1999. Cidades versus entulhos. In: SEMINÁRIO: DESENVOLVIMENTO SUSTENTÁVEL E A RECICLAGEM NA CONSTRUÇÃO CIVIL, 2, São Paulo. Anais. IBRACON. pp.56-67. (Comitê Técnico CT 206: Meio ambiente). 
BuenO, B.S.; VILAR, O.M. (1995). Mecânica dos solos I. São Carlos, EESC-USP. /Nota de aula/.

Bueno, B.S.; VILAR, O.M. (1996). Mecânica dos solos II. São Carlos, EESCUSP. /Nota de aula/.

CAmargo, A. (1995). Minas de entulho. Téchne. n.15, p.15-19.

CAvalheiro, O.P.; Muller, L.E. (1991). Influência do revestimento na resistência de pequenas paredes de blocos cerâmicos comuns. In: JORNADAS Sul-Americanas de Engenharia Estrutural, 25., Porto Alegre, 1991. Anais. Porto Alegre, UFRGS. V.4, p.25-36.

Cavalheiro, O.P.; Pozzobon, M.A.; SAntos, M.D.F. (2000). Considerações sobre o uso de juntas verticais não preenchidas na alvenaria. In: JORNADAS Sul-Americanas de Engenharia Estrutural, ., Punta Del Este, 2000. Anais. Punta Del Este.

CAvani, G.R.; Oliveira, M.B. (2002). Saibro. Téchne, São Paulo, n.63, p.10.

Corbioli, N. (1996). Do caos à solução. Construção São Paulo. n.2505, p.4-7.

Cosmo, W. (2001). Lixão de Goioerê vira deposito de embalagens de agrotóxico. Gazeta do Povo, Curitiba, 11 maio.

DiAZ, O.R.V. (1998). Método de dosagem de concretos de elevado desempenho. São Paulo, Pini.

EurocóDigo 6. ENV 1996-1-1 - Proyecto de estructuras de fábrica. Parte 1-1: Reglas generales para edifícios. Reglas para fábrica y fábrica armada. Madrid, España. pp176. 1997.

FONSECA, F.B. (1999). Influência do agregado reciclado nas características da argamassa armada utilizada nas construções de argamassa armada. Bauru. Trabalho de conclusão de curso (Monografia) - Departamento de Engenharia Civil, Universidade Estadual Paulista. 
GonÇALVES, R.D.C. (2001). Agregados reciclados de residuos de concreto: um novo material para dosagens estruturais. São Carlos. Dissertação (Mestrado) Escola de Engenharia de São Carlos, Universidade de São Paulo.

Grossi, P. (2001). Selo de Qualidade ABCP. In: SEMINÁRIO NACIONAL SOBRE Blocos de concreto para alvenaria e pavimentação, São Paulo, Anais. São Paulo, ABCP/Instituto de Engenharia.

HAMASSAKI, L.T. et al. (1997). Uso de entulho como agregado para argamassas de alvenaria. In: RECICLAGEM E REUTILIZAÇÃO DE RESÍDUOS COMO MATERIAIS DE CONSTRUÇão CIVIL, São Paulo, 1997. Anais. São Paulo, EPUSP.

HAMASSAKI, L.T. (2000). Reciclagem de entulho. In: LiXo Municipal: MANUAL DE GERENCIAMENTO INTEGRADO. (2000). 2.ed. São Paulo, IPT/CEMPRE. cap.4, p.79-247: Processamento do lixo.

HANSEN, T.C. (1992). Recycling of demolished concrete and masonry, London. E\&FN Spon - Chapman \& Hall.

HARDING, M.A. (1997). RCC: an RX for rehabiliting embankment dams. Concrete Constructions. v.42, n.1, Jun.

Helene, P.R.L.; Terzian, P. (1995). Manual de dosagem e controle do concreto. São Paulo, Pini.

ÍNDICE em declínio (2001). Téchne, São Paulo, n.55, p.17, out.

Juste, A.E. (2001). Estudo da Resistência e da deformabilidade da alvenaria de blocos de concreto submetida a esforços de compressão. São Carlos. Dissertação (Mestrado) - Escola de Engenharia de São Carlos, Universidade de São Paulo.

Krumbein, W.C.; Sloss, L.L. (1963). Stratigraphy and Asedimentation. WH Freeman, 12ed, 660pp. 
LATTERZA, L.M. (1998). Concreto com agregado graúdo proveniente da reciclagem de resíduos de construção e demolição um novo material para fabricação de painéis leves de vedação. São Carlos. Dissertação (Mestrado) Escola de Engenharia de São Carlos, Universidade de São Paulo.

LeITE, M.B. et al. (2000). Agregado reciclado para concreto: proposta de desenvolvimento de um método para determinação da taxa de absorção do material. In: Congresso Brasileiro do Concreto, 42., Fortaleza, 2000. Anais. São Paulo, IBRACON [CD-ROM].

LEVY, S.M. (1997). Reciclagem do entulho de construção civil, para utilização como agregado de argamassas e concretos. São Paulo. Dissertação (Mestrado) - Escola Politécnica, Universidade de São Paulo.

LiBORIO, J.B.L. (2001). - Notas de aula da disciplina de pós-graduação: "SAP 4847 - Patologia na construção civil” - São Carlos, EESC-USP.

LuNA, R.L. (2001). Rumos imobiliários. Téchne, São Paulo, n.57, p.20-21, dez.

Medeiros, J.S. (1993). Alvenaria não armada de blocos de concreto: produção de componentes e parâmetros de projeto. São Paulo. Dissertação (Mestrado) Escola Politécnica, Universidade de São Paulo.

MeHTA, P.K. (1994). Concreto: estrutura, propriedades e materiais. São Paulo, Pini.

Mohamad, G. (1998). Comportamento mecânico na ruptura de prismas de blocos de concreto. Florianópolis. Dissertação (Mestrado) - Universidade Federal de Santa Catarina.

Neville, A.M. (1997). Propriedades do concreto. 2.ed. São Paulo, Pini.

Novaes, W. (2001). Um avanço no lixo. O Estado de São Paulo, São Paulo. www.estadao.com.br (17ago). 
NunES, F.L. (1998). Influência da dosagem na carbonatação dos concretos. São Paulo. Dissertação (Mestrado) - Escola Politécnica, Universidade de São Paulo.

OliveIRA, F.L. (2001). Reabilitação de estruturas de alvenaria para aplicação de revestimentos resistentes de argamassa armada. São Carlos. Tese (Doutorado) - Escola de Engenharia de São Carlos, Universidade de São Paulo.

PARIS, J.M.F. (1973). La carbonatación de la pasta hidratada de cemento Portland. Interpretación físico-química. Monografia del Instituto Eduardo Torroja de la construcción y del cemento, Madrid, n.310.

Pimienta, P.; Delmotte, P. (1998). Recycled aggregate used for making building blocks. In: INTERNATIONAL SYMPOSIUM ON SUSTAINABLE CONSTRUCTION: USE OF ReCYCLED CONCRETE Aggregate, London, 1998. Proceedings. London, p.291-301., Thomas Telford.

Pinto, T.P. (1986). Utilização de resíduos de construção. Estudo do uso em argamassas. São Carlos. Dissertação (Mestrado) - Escola de Engenharia de São Carlos, Universidade de São Paulo.

PINTO, T.P. (1997). Resultados da gestão diferenciada. Téchne. n.31, p.31-34.

Pignanelli, P. (2001). O homem que protege casas, casas... [entrevista]. Prisma: soluções construtivas com blocos de concreto, São Paulo, n.1, p.6-11.

QUEBAUD, M.R. (1999). Influência do teor em agregados provenientes da reciclagem de materiais de demolição (agregados reciclados) na permeabilidade do concreto. In: CONGRESSO BRASILEIRO DO CONCRETO, 41., Salvador, 1999. Anais. São Paulo, IBRACON [CD-ROM].

RAmalho, M.A.; CorrÊA, M.R.S. (2001). Alvenaria estrutural. São Carlos, EESC-USP. /Nota de aula da disciplina: "SET 606 - Alvenaria Estrutural”/. 
RiBEIRO, A.B. (2000). Influência da dosagem de aglomerante na resistência às tensões do concreto compactado com rolo. In: CONGRESSO BRASILEIRO DO COnCRETO, 42., Fortaleza, 2000. Anais. São Paulo, IBRACON [CD-ROM].

Ribeiro, A.B.; AlmeidA, I. R. (2000). Study on high performance roller compacted concrete. Materials and Structures, v.33, p.398-402, July.

Richardson, M.G. (1988). Carbonation of Reinforced Concrete: its causes and management. Citis Ltd, Publishers, New York.

Silva, V.M. (2002). Contribuição ao estudo da carbonatação em concretos e argamassas executados com e sem adição de sílica ativa. São Carlos. Dissertação (Mestrado) - Escola de Engenharia de São Carlos, Instituto de física de São Carlos, Instituto de Química de São Carlos, Universidade de São Paulo.

TERZIAN, P. (2001). Controle de fissuras por retração plástica em pisos industriais de concreto, Téchne. São Paulo, n.51, p.70-72, out.

Vasconcelos, A.C.; Giammusso, S.E., P.R.L. (1998). O misterioso módulo de elasticidade. In: CONGRESSO BrasileIRo DO CONCRETO, 40., Rio de Janeiro, 1998. Anais. São Paulo, IBRACON [CD-ROM].

Zordan, S.E.; PAUlon, V.A.; John, V.M. (1999). Concreto confeccionado com entulho reciclado: avaliação do desempenho em função do consumo de cimento. In: II INTERNATIONAL CONFERENCE ON High-PERFormance Concrete , And Performance and Quality of Concrete Structures, Gramado, 1999. Anais. São Paulo, ACI, jun. 
ANEXO $\underline{A}$

PRINCIPAIS CARACTERÍSTICAS DOS LOTES DE BLOCOS 
Tabela A.1 - Determinação do valor característico da resistência à compressão do bloco

\begin{tabular}{|c|c|c|c|c|c|c|c|c|c|c|c|c|}
\hline & \multirow{2}{*}{$\begin{array}{l}\text { idade } \\
\text { (dias) } \\
\end{array}$} & \multirow{2}{*}{$\mathrm{CP}$} & \multirow{2}{*}{$\begin{array}{c}\mathrm{A} \\
\left(\mathrm{cm}^{2}\right)\end{array}$} & \multirow{2}{*}{$\begin{array}{c}F \\
(\mathrm{kN})\end{array}$} & \multirow{2}{*}{$\begin{array}{c}f_{c, j} \\
(\mathrm{MPa})\end{array}$} & \multirow{2}{*}{ média } & \multicolumn{4}{|c|}{ (MPa) } & \multirow{2}{*}{$\begin{array}{c}\mathrm{Sd} \\
(\mathrm{MPa})\end{array}$} & \multirow{2}{*}{$\begin{array}{l}\text { CV } \\
(\%)\end{array}$} \\
\hline & & & & & & & estimado & $85 \%$ & $\psi 6 . \mathrm{f}_{\mathrm{b} 1}$ & $\mathrm{f} \mathrm{bk}$ & & \\
\hline \multirow{16}{*}{ 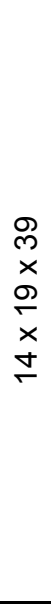 } & \multirow{6}{*}{7} & 1 & 539,92 & 404,2 & 7,486 & \multirow{6}{*}{9,87} & \multirow{6}{*}{6,69} & \multirow{6}{*}{8,39} & \multirow{6}{*}{6,66} & \multirow{6}{*}{7,00} & \multirow{6}{*}{1,42} & \multirow{6}{*}{14,4} \\
\hline & & 2 & 540,34 & 587,8 & 10,878 & & & & & & & \\
\hline & & 3 & 539,64 & 533,4 & 9,884 & & & & & & & \\
\hline & & 4 & 540,11 & 490,8 & 9,087 & & & & & & & \\
\hline & & 5 & 539,88 & 616,0 & 11,410 & & & & & & & \\
\hline & & 6 & 540,29 & 565,4 & 10,465 & & & & & & & \\
\hline & \multirow{6}{*}{28} & 1 & 539,69 & 590,4 & 10,940 & \multirow{6}{*}{11,22} & \multirow{6}{*}{9,06} & \multirow{6}{*}{9,54} & \multirow{6}{*}{8,22} & \multirow{6}{*}{8,50} & \multirow{6}{*}{1,56} & \multirow{6}{*}{13,9} \\
\hline & & 2 & 539,55 & 705,8 & 13,081 & & & & & & & \\
\hline & & 3 & 539,04 & 569,1 & 10,558 & & & & & & & \\
\hline & & 4 & 540,76 & 561,9 & 10,391 & & & & & & & \\
\hline & & 5 & 539,88 & 707,7 & 13,109 & & & & & & & \\
\hline & & 6 & 538,16 & 496,8 & 9,231 & & & & & & & \\
\hline & \multirow{4}{*}{250} & 1 & 538,26 & 867,7 & 16,120 & & & & & & & \\
\hline & & 2 & 540,11 & 750,2 & 13,890 & & & 1257 & 1180 & & & \\
\hline & & 3 & 539,48 & 715,3 & 13,259 & 14,19 & 12,63 & 12,51 & 11,80 & 12,0 & 1,43 & 9,1 \\
\hline & & 4 & 538,95 & 857,3 & 15,907 & & & & & & & \\
\hline & & 1 & 267,34 & 296,3 & 11,083 & & & & & & & \\
\hline & & 2 & 267,95 & 260,8 & 9,733 & & & & & & & \\
\hline & 7 & 3 & 268,52 & 300,1 & 11,176 & 1164 & 817 & 887 & 828 & 850 & 086 & 82 \\
\hline & 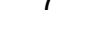 & 4 & 267,89 & 249,1 & 9,299 & 11,04 & 0,11 & 0,01 & $0,<0$ & 0,50 & 0,00 & 0,2 \\
\hline 5 & & 5 & 267,74 & 290,7 & 10,858 & & & & & & & \\
\hline$\stackrel{\times}{a}$ & & 6 & 267,65 & 473,5 & 17,691 & & & & & & & \\
\hline $\bar{x}$ & & 1 & 267,34 & 271,6 & 10,160 & & & & & & & \\
\hline$\dot{\theta}$ & & 2 & 267,65 & 445,9 & 16,660 & & & & & & & \\
\hline & 28 & 3 & 266,76 & 273,5 & 10,253 & 1487 & 583 & 1264 & 904 & & 399 & \\
\hline & 20 & 4 & 266,88 & 527,7 & 19,773 & 14,01 & 0,03 & 12,04 & $y, 04$ & 9,50 & 3,99 & $\angle b, 0$ \\
\hline & & 5 & 266,47 & 474,6 & 17,811 & & & & & & & \\
\hline & & 6 & 267,42 & 390,0 & 14,584 & & & & & & & \\
\hline
\end{tabular}


Tabela A.2 - Teor de umidade, absorção de água, área líquida e massa específica dos blocos

\begin{tabular}{|c|c|c|c|c|c|c|c|c|c|c|c|c|}
\hline série & \multicolumn{3}{|c|}{ umidade $\%$} & \multicolumn{3}{|c|}{ absorção \% } & \multicolumn{3}{|c|}{ área líquida $\left(\mathrm{cm}^{2}\right)$} & \multicolumn{3}{|c|}{$\begin{array}{c}\text { massa específica } \\
\left(\mathrm{g} / \mathrm{cm}^{3}\right)\end{array}$} \\
\hline T1 & $\begin{array}{l}15,7 \\
25,3 \\
21,2 \\
\end{array}$ & 20,7 & 4,8 & $\begin{array}{l}10,6 \\
10,5 \\
11,3 \\
\end{array}$ & 10,8 & 0,4 & $\begin{array}{l}282,5 \\
280,5 \\
274,0\end{array}$ & 279,0 & 4,5 & $\begin{array}{l}1,93 \\
1,90 \\
1,87\end{array}$ & 1,90 & 0,0 \\
\hline TM8 & $\begin{array}{l}- \\
- \\
-\end{array}$ & - & - & $\begin{array}{r}12,0 \\
10,1 \\
9,3 \\
\end{array}$ & 10,5 & 1,4 & $\begin{array}{c}268,4 \\
- \\
-\end{array}$ & 268,4 & 0,0 & $\begin{array}{l}1,88 \\
1,89 \\
1,93 \\
\end{array}$ & 1,90 & 0,0 \\
\hline TM8 m1 & $\begin{array}{l}- \\
- \\
- \\
\end{array}$ & - & - & $\begin{array}{l}8,7 \\
8,7 \\
8,7 \\
\end{array}$ & 8,7 & 0,0 & $\begin{array}{l}- \\
- \\
- \\
\end{array}$ & - & - & $\begin{array}{l}1,97 \\
1,96 \\
1,98 \\
\end{array}$ & 1,97 & 0,0 \\
\hline TM8 m2 & $\begin{array}{l}- \\
-\end{array}$ & - & - & $\begin{array}{l}9,2 \\
9,1\end{array}$ & 9,2 & 0,1 & $\begin{array}{l}- \\
-\end{array}$ & - & - & $\begin{array}{l}2,01 \\
2,01\end{array}$ & 2,01 & 0,0 \\
\hline TMR6 & $\begin{array}{l}- \\
- \\
-\end{array}$ & - & - & $\begin{array}{l}16,5 \\
16,2 \\
15,9 \\
\end{array}$ & 16,2 & 0,3 & $\begin{array}{l}- \\
- \\
-\end{array}$ & - & - & $\begin{array}{l}1,68 \\
1,71 \\
1,72 \\
\end{array}$ & 1,70 & 0,0 \\
\hline $19 \times 14 \times 39$ & $\begin{array}{l}49,6 \\
51,5 \\
60,6 \\
\end{array}$ & 53,9 & 5,9 & $\begin{array}{l}8,2 \\
7,3 \\
8,7\end{array}$ & 8,1 & 0,7 & $\begin{array}{l}304,9 \\
307,5 \\
305,6\end{array}$ & 306,0 & 1,3 & $\begin{array}{l}1,99 \\
2,00 \\
1,99\end{array}$ & 1,99 & 0,0 \\
\hline $19 \times 14 \times 19$ & $\begin{array}{l}45,3 \\
55,1 \\
50,9\end{array}$ & 50,4 & 4,9 & $\begin{array}{l}9,3 \\
8,8 \\
8,6\end{array}$ & 8,9 & 0,4 & $\begin{array}{l}159,6 \\
158,2 \\
160,2\end{array}$ & 159,3 & 1,0 & $\begin{array}{l}1,93 \\
1,96 \\
2,03\end{array}$ & 1,97 & 0,1 \\
\hline
\end{tabular}


ANEXO $\underline{B}$

DESEMPENHO MECÂNICO DOS $\underline{\text { PRISMAS, }}$ PAREDES $\underline{E}$ ARGAMASSAS 
Tabela B.1 - Resistência à compressão axial e módulo de elasticidade secante

\begin{tabular}{|c|c|c|c|c|c|c|c|c|c|}
\hline série & tipo de CP & \multicolumn{3}{|c|}{ data } & $\begin{array}{c}\begin{array}{c}F \text { ruptura } \\
(\mathrm{kN})\end{array} \\
\end{array}$ & $\begin{array}{r}f c, j \\
\text { indiv }\end{array}$ & $\begin{array}{l}\text { APa) } \\
\text { média }\end{array}$ & $\begin{array}{c}\begin{array}{c}\text { Epa } \\
(\mathrm{MPa})\end{array} \\
\end{array}$ & $\begin{array}{c}\mathrm{Eb} \\
(\mathrm{MPa})\end{array}$ \\
\hline \multirow{4}{*}{ R 1} & PrR & $\overline{~ 19 / 11}$ & $6 / 12$ & 17 & 387,5 & 7,17 & - & - & 12.439 \\
\hline & Pa R & $19 / 11$ & $6 / 12$ & 17 & 797,7 & 7,20 & - & 4.841 & 22.082 \\
\hline & arg assent R1 & $19 / 11$ & $6 / 12$ & 17 & 11,3 & 5,76 & & - & - \\
\hline & arg assent R2 & $19 / 11$ & $6 / 12$ & 17 & 11,4 & 5,81 & 5,18 & - & - \\
\hline \multirow{4}{*}{ R 2} & $\operatorname{Pr} R$ & $19 / 11$ & $7 / 12$ & 18 & 345,0 & 6,35 & - & - & 9.249 \\
\hline & $\mathrm{Pa} \mathrm{R}$ & $19 / 11$ & $7 / 12$ & 18 & 630,8 & 5,78 & - & 5.226 & 17.124 \\
\hline & arg assent R1 & $19 / 11$ & $7 / 12$ & 18 & 11,7 & 5,96 & & - & - \\
\hline & arg assent R2 & $19 / 11$ & $7 / 12$ & 18 & 11,6 & 5,91 & 5,93 & - & - \\
\hline \multirow{4}{*}{ R 3} & Pr R & $19 / 11$ & $7 / 12$ & 18 & 321,5 & 5,96 & - & - & 10.320 \\
\hline & Pa R & $19 / 11$ & $7 / 12$ & 18 & 699,1 & 6,36 & - & 4.391 & 20.886 \\
\hline & arg assent R1 & $19 / 11$ & $7 / 12$ & 18 & 12,1 & 6,16 & & - & - \\
\hline & arg assent R2 & $19 / 11$ & $7 / 12$ & 18 & 12,1 & 6,16 & 6,16 & - & - \\
\hline \multirow{6}{*}{ RN 1} & Pr RN & $19 / 11$ & $7 / 12$ & 18 & 314,9 & 5,79 & - & - & - \\
\hline & $\mathrm{Pa}$ RN & $19 / 11$ & $7 / 12$ & 18 & 572,8 & 5,24 & - & 6.018 & - \\
\hline & arg assent R1 & $19 / 11$ & $7 / 12$ & 18 & 12,2 & 6,21 & 624 & - & - \\
\hline & arg assent R2 & $19 / 11$ & $7 / 12$ & 18 & 12,3 & 6,26 & $0, \angle 4$ & - & - \\
\hline & arg revest N1 & $22 / 11$ & $7 / 12$ & 15 & 11,0 & 5,60 & & - & - \\
\hline & arg revest N2 & $22 / 11$ & $7 / 12$ & 15 & 10,5 & 5,35 & 5,47 & - & - \\
\hline \multirow{6}{*}{ RN 2} & Pr RN & $19 / 11$ & $10 / 12$ & 21 & 387,3 & 7,16 & - & - & - \\
\hline & $\mathrm{Pa} \mathrm{RN}$ & $19 / 11$ & $10 / 12$ & 21 & 605,2 & 5,51 & - & 6.150 & - \\
\hline & arg assent R1 & $19 / 11$ & $10 / 12$ & 21 & 12,5 & 6,37 & 6.47 & - & - \\
\hline & arg assent R2 & $19 / 11$ & $10 / 12$ & 21 & 12,9 & 6,57 & 0,47 & - & - \\
\hline & arg revest $\mathrm{N} 1$ & $22 / 11$ & $10 / 12$ & 18 & 15,1 & 7,69 & & - & - \\
\hline & arg revest N2 & $22 / 11$ & $10 / 12$ & 18 & 10,3 & 5,25 & 0,47 & - & - \\
\hline \multirow{6}{*}{ RN 3} & Pr RN & $19 / 11$ & $10 / 12$ & 21 & 305,8 & 5,55 & - & - & - \\
\hline & $\mathrm{Pa}$ RN & $19 / 11$ & $10 / 12$ & 21 & 493,8 & 4,48 & - & 6.171 & - \\
\hline & arg assent R1 & $19 / 11$ & $10 / 12$ & 21 & 14,3 & 7,28 & 749 & - & - \\
\hline & arg assent R2 & $19 / 11$ & $10 / 12$ & 21 & 15,1 & 7,69 & 1,49 & - & - \\
\hline & arg revest N1 & $22 / 11$ & $10 / 12$ & 18 & 12,5 & 6,37 & & - & - \\
\hline & arg revest N2 & $22 / 11$ & $10 / 12$ & 18 & 12,9 & 6,57 & 6,47 & - & - \\
\hline \multirow{6}{*}{ RR 1} & Pr RR & $19 / 11$ & $10 / 12$ & 21 & 392,9 & 7,19 & - & - & - \\
\hline & Pa RR & $19 / 11$ & $10 / 12$ & 21 & 609,2 & 5,51 & - & 8.434 & - \\
\hline & arg assent R1 & $19 / 11$ & $10 / 12$ & 21 & 12,4 & 6,32 & 9 & - & - \\
\hline & arg assent R2 & $19 / 11$ & $10 / 12$ & 21 & 11,9 & 6,06 & & - & - \\
\hline & arg revest R1 & $22 / 11$ & $10 / 12$ & 18 & 11,2 & 5,70 & & - & - \\
\hline & arg revest $\mathrm{R} 2$ & $22 / 11$ & $10 / 12$ & 18 & 17,5 & 8,91 & 1,31 & - & - \\
\hline \multirow{6}{*}{ RR 2} & Pr RR & $19 / 11$ & $11 / 12$ & 22 & 321,4 & 5,92 & - & - & - \\
\hline & Pa RR & $19 / 11$ & $11 / 12$ & 22 & 690,1 & 6,30 & - & 8.505 & - \\
\hline & arg assent R1 & $19 / 11$ & $11 / 12$ & 22 & 12,5 & 6,37 & & - & - \\
\hline & arg assent R2 & $19 / 11$ & $11 / 12$ & 22 & 12,7 & 6,47 & 0,42 & - & - \\
\hline & arg revest $\mathrm{R} 1$ & $22 / 11$ & $11 / 12$ & 19 & 11,5 & 5,86 & & - & - \\
\hline & arg revest R2 & $22 / 11$ & $11 / 12$ & 19 & 12,3 & 6,26 & 6,06 & - & - \\
\hline \multirow{6}{*}{ RR 3} & Pr RR & $21 / 11$ & $11 / 12$ & 20 & 375,8 & 6,95 & - & - & - \\
\hline & $\mathrm{Pa} R \mathrm{R}$ & $21 / 11$ & $11 / 12$ & 20 & 664,8 & 6,01 & - & 8.016 & - \\
\hline & arg assent R1 & $21 / 11$ & $11 / 12$ & 20 & 9,5 & 4,84 & 4.94 & - & - \\
\hline & arg assent R2 & $21 / 11$ & $11 / 12$ & 20 & 9,9 & 5,04 & 4,94 & - & - \\
\hline & arg revest R1 & $22 / 11$ & $11 / 12$ & 19 & 14,0 & 7,13 & & - & - \\
\hline & arg revest $\mathrm{R} 2$ & $22 / 11$ & $11 / 12$ & 19 & 13,4 & 6,82 & & - & - \\
\hline
\end{tabular}




\begin{tabular}{|c|c|c|c|c|c|c|c|c|c|}
\hline série & tipo de CP & \multicolumn{3}{|c|}{ data } & $\begin{array}{c}\mathrm{F} \text { ruptura } \\
(\mathrm{kN})\end{array}$ & \multicolumn{2}{|c|}{ fc, j (MPa) } & $\begin{array}{c}\text { Epa } \\
(\mathrm{MPa})\end{array}$ & $\begin{array}{c}\mathrm{Eb} \\
(\mathrm{MPa})\end{array}$ \\
\hline \multirow{4}{*}{ N 1} & $\operatorname{PrN}$ & $20 / 11$ & $11 / 12$ & 21 & 336,4 & 6,22 & - & - & 10.900 \\
\hline & $\mathrm{Pa} \mathrm{N}$ & $20 / 11$ & $11 / 12$ & 21 & 569,2 & 5,13 & - & 4.671 & 14.442 \\
\hline & arg assent N1 & $20 / 11$ & $11 / 12$ & 21 & 7,8 & 3,97 & 407 & - & - \\
\hline & arg assent N2 & $20 / 11$ & $11 / 12$ & 21 & 8,2 & 4,18 & 4,07 & - & - \\
\hline \multirow{4}{*}{ N 2} & $\operatorname{Pr} N$ & $20 / 11$ & $12 / 12$ & 22 & 283,6 & 5,23 & - & - & 11.292 \\
\hline & $\mathrm{Pa} \mathrm{N}$ & $20 / 11$ & $12 / 12$ & 22 & 516,8 & 4,67 & - & 5.583 & 18.048 \\
\hline & arg assent N1 & $20 / 11$ & $12 / 12$ & 22 & 7,6 & 3,87 & & - & - \\
\hline & arg assent N2 & $20 / 11$ & $12 / 12$ & 22 & 7,8 & 3,97 & 3,92 & - & - \\
\hline \multirow{4}{*}{ N 3} & $\operatorname{Pr} \mathrm{N}$ & $20 / 11$ & $12 / 12$ & 22 & 290,2 & 5,33 & - & - & 10.660 \\
\hline & $\mathrm{Pa} \mathrm{N}$ & $20 / 11$ & $12 / 12$ & 22 & 529,8 & 4,84 & - & 5.188 & 10.045 \\
\hline & arg assent N1 & $20 / 11$ & $12 / 12$ & 22 & 8,3 & 4,23 & & - & - \\
\hline & arg assent N2 & $20 / 11$ & $12 / 12$ & 22 & 8,7 & 4,43 & 4,33 & - & - \\
\hline \multirow{6}{*}{ NN 1} & $\operatorname{PrN}$ & $20 / 11$ & $12 / 12$ & 22 & 283,4 & 5,25 & - & - & - \\
\hline & $\mathrm{PaN}$ & $20 / 11$ & $12 / 12$ & 22 & 577,3 & 5,25 & - & 8.093 & - \\
\hline & arg assent $\mathrm{N} 1$ & $20 / 11$ & $12 / 12$ & 22 & 8,0 & 4,07 & 420 & - & - \\
\hline & arg assent N2 & $20 / 11$ & $12 / 12$ & 22 & 8,5 & 4,33 & $4, \angle U$ & - & - \\
\hline & arg revest N1 & $23 / 11$ & $12 / 12$ & 19 & 11,6 & 5,91 & & - & - \\
\hline & arg revest N2 & $23 / 11$ & $12 / 12$ & 19 & 12,2 & 6,21 & 6,06 & - & - \\
\hline \multirow{6}{*}{ NN 2} & $\operatorname{Pr} N$ & $20 / 11$ & $13 / 12$ & 23 & 334,8 & 6,20 & - & - & - \\
\hline & $\mathrm{Pa} \mathrm{N}$ & 20/11 & $13 / 12$ & 23 & 450,2 & 4,08 & - & 7.935 & - \\
\hline & arg assent N1 & $20 / 11$ & $13 / 12$ & 23 & 9,8 & 4,99 & 497 & - & - \\
\hline & arg assent N2 & $20 / 11$ & $13 / 12$ & 23 & 9,7 & 4,94 & 4,97 & - & - \\
\hline & arg revest $\mathrm{N} 1$ & $23 / 11$ & $13 / 12$ & 20 & 10,0 & 5,09 & & - & - \\
\hline & arg revest N2 & $23 / 11$ & $13 / 12$ & 20 & 11,3 & 5,76 & 5,42 & - & - \\
\hline \multirow{6}{*}{ NN 3} & $\operatorname{Pr} N$ & $20 / 11$ & $13 / 12$ & 23 & 397,8 & 7,31 & - & - & - \\
\hline & $\mathrm{Pa} \mathrm{N}$ & 20/11 & $13 / 12$ & 23 & 561,3 & 5,06 & - & 10.048 & - \\
\hline & arg assent $\mathrm{N} 1$ & $20 / 11$ & $13 / 12$ & 23 & 12,6 & 6,42 & & - & - \\
\hline & arg assent N2 & $20 / 11$ & $13 / 12$ & 23 & 10,4 & 5,30 & 5,86 & - & - \\
\hline & arg revest N1 & $23 / 11$ & $13 / 12$ & 20 & 10,4 & 5,30 & & - & - \\
\hline & arg revest N2 & $23 / 11$ & $13 / 12$ & 20 & 14,3 & 7,28 & 6,29 & - & - \\
\hline \multirow{6}{*}{ NR 1} & Pr NR & $20 / 11$ & $13 / 12$ & 23 & 342,8 & 6,30 & - & - & - \\
\hline & $\mathrm{Pa} N R$ & $20 / 11$ & $13 / 12$ & 23 & 607,7 & 5,51 & - & 5.972 & - \\
\hline & arg assent $\mathrm{N} 1$ & $20 / 11$ & $13 / 12$ & 23 & 13,4 & 6,82 & 600 & - & - \\
\hline & arg assent N2 & $20 / 11$ & $13 / 12$ & 23 & 10,5 & 5,35 & & - & - \\
\hline & arg revest $\mathrm{R} 1$ & $22 / 11$ & $13 / 12$ & 21 & 14,6 & 7,44 & & - & - \\
\hline & arg revest $\mathrm{R} 2$ & $22 / 11$ & $13 / 12$ & 21 & 14,7 & 7,49 & 1,40 & - & - \\
\hline \multirow{6}{*}{ NR 2} & Pr NR & $20 / 11$ & $14 / 12$ & 24 & 277,0 & 5,07 & - & - & - \\
\hline & Pa NR & $20 / 11$ & $14 / 12$ & 24 & 386,1 & 3,48 & - & 7.059 & - \\
\hline & arg assent $\mathrm{N} 1$ & $20 / 11$ & $14 / 12$ & 24 & 10,3 & 5,25 & 7 & - & - \\
\hline & arg assent N2 & $20 / 11$ & $14 / 12$ & 24 & 11,2 & 5,70 & 1 & - & - \\
\hline & arg revest $\mathrm{R} 1$ & $22 / 11$ & $14 / 12$ & 22 & 10,2 & 5,19 & & - & - \\
\hline & arg revest $\mathrm{R} 2$ & $22 / 11$ & $14 / 12$ & 22 & 10,9 & 5,55 & 5,31 & - & - \\
\hline \multirow{6}{*}{ NR 3} & Pr NR & $20 / 11$ & $14 / 12$ & 24 & 368,0 & 6,76 & - & - & - \\
\hline & $\mathrm{Pa} N R$ & $20 / 11$ & $14 / 12$ & 24 & 597,3 & 5,45 & - & 8.055 & - \\
\hline & arg assent N1 & $20 / 11$ & $14 / 12$ & 24 & 16,5 & 8,40 & 8.17 & - & - \\
\hline & arg assent N2 & $20 / 11$ & $14 / 12$ & 24 & 15,6 & 7,94 & 8,17 & - & - \\
\hline & arg revest $\mathrm{R} 1$ & $23 / 11$ & $14 / 12$ & 21 & 12,1 & 6,16 & & - & - \\
\hline & arg revest $\mathrm{R} 2$ & $23 / 11$ & $14 / 12$ & 21 & 12,0 & 6,11 & & - & - \\
\hline
\end{tabular}


Tabela B.2 - Resistência à compressão de prismas e módulo de elasticidade longitudinal $\left(E_{s l}\right)$ e transversal $\left(E_{s t}\right)$ de blocos de concreto com $e$ sem revestimento

\begin{tabular}{|c|c|c|c|c|c|c|}
\hline série & tipo de CP & $\mathrm{F}(\mathrm{kN})$ & $\begin{array}{r}f c, j \\
\text { indiv }\end{array}$ & $\begin{array}{l}\mathrm{Pa} \text { ) } \\
\text { média }\end{array}$ & $\mathrm{E}_{\mathrm{sl}}(\mathrm{MPa})$ & $\mathrm{E}_{\mathrm{st}}(\mathrm{MPa})$ \\
\hline \multirow{3}{*}{ R 1} & Pr R & 350,5 & 6,42 & - & 12.530 & 11.583 \\
\hline & arg assent R1 & 10,3 & 5,25 & 547 & - & - \\
\hline & arg assent R2 & 11,2 & 5,70 & 5,47 & - & - \\
\hline \multirow{3}{*}{ R 2} & Pr R & 427,3 & 7,83 & - & 12.876 & 13.653 \\
\hline & arg assent R1 & 11,1 & 5,65 & 560 & - & - \\
\hline & arg assent R2 & 10,9 & 5,55 & 5,00 & - & - \\
\hline \multirow{3}{*}{ R 3} & Pr R & 494,9 & 9,06 & - & 12.520 & 13.874 \\
\hline & arg assent R1 & 10,7 & 5,45 & & - & - \\
\hline & arg assent R2 & 10,8 & 5,50 & 5,47 & - & - \\
\hline \multirow{5}{*}{ RN 1} & Pr RN & 323,3 & 5,92 & - & 12.396 & 12.905 \\
\hline & arg assent R1 & 11,3 & 5,76 & & - & - \\
\hline & arg assent R2 & 10,8 & 5,50 & 5,63 & - & - \\
\hline & arg revest N1 & 9,8 & 4,99 & & - & - \\
\hline & arg revest N2 & 10,5 & 5,35 & 5,16 & - & - \\
\hline \multirow{5}{*}{ RN 2} & Pr RN & 391,7 & 7,17 & - & 10.567 & 13.037 \\
\hline & arg assent R1 & 11,1 & 5,65 & & - & - \\
\hline & arg assent R2 & 11,1 & 5,65 & 5,65 & - & - \\
\hline & arg revest N1 & 10,3 & 5,25 & & - & - \\
\hline & arg revest N2 & 10,7 & 5,45 & 5,35 & - & - \\
\hline \multirow{5}{*}{ RN 3} & Pr RN & 335,9 & 6,15 & - & 12.472 & 13.651 \\
\hline & arg assent R1 & 10,5 & 5,35 & & - & - \\
\hline & arg assent R2 & 9,9 & 5,04 & 19 & - & - \\
\hline & arg revest N1 & 11,6 & 5,91 & 570 & - & - \\
\hline & arg revest N2 & 10,8 & 5,50 & 5,10 & - & - \\
\hline \multirow{5}{*}{ RR 1} & Pr RR & 330,0 & 6,04 & - & 10.822 & 14.504 \\
\hline & arg assent R1 & 10,9 & 5,55 & 565 & - & - \\
\hline & arg assent R2 & 11,3 & 5,76 & 5,65 & - & - \\
\hline & arg revest $\mathrm{R} 1$ & 11,4 & 5,81 & & - & - \\
\hline & arg revest $\mathrm{R} 2$ & 11,0 & 5,60 & 5,70 & - & - \\
\hline \multirow{5}{*}{ RR 2} & Pr RR & 402,2 & 7,37 & - & 12.108 & 14.762 \\
\hline & arg assent R1 & 11,3 & 5,76 & 600 & - & - \\
\hline & arg assent R2 & 12,6 & 6,42 & 6,09 & - & - \\
\hline & arg revest $\mathrm{R} 1$ & 10,5 & 5,35 & & - & - \\
\hline & arg revest R2 & 11,1 & 5,65 & 5,50 & - & - \\
\hline \multirow{5}{*}{ RR 3} & Pr RR & 407,0 & 7,45 & - & 12.120 & 12.928 \\
\hline & arg assent R1 & 12,7 & 6,47 & 637 & - & - \\
\hline & arg assent R2 & 12,3 & 6,26 & 6 & - & - \\
\hline & arg revest $\mathrm{R} 1$ & 11,4 & 5,81 & & - & - \\
\hline & arg revest $\mathrm{R} 2$ & 10,8 & 5,50 & & - & - \\
\hline
\end{tabular}

Data de assentamento: 16 de julho

Data de revestimento: 20 de julho

Data de ensaio: 8 e 9 de agosto 


\begin{tabular}{|c|c|c|c|c|c|c|}
\hline série & tipo de CP & $\mathrm{F}(\mathrm{kN})$ & $\begin{array}{l}f c, j \\
\text { indiv }\end{array}$ & $\begin{array}{l}\text { APa) } \\
\text { média }\end{array}$ & $\mathrm{E}_{\mathrm{sl}}(\mathrm{MPa})$ & $\mathrm{E}_{\text {st }}(\mathrm{MPa})$ \\
\hline \multirow[b]{2}{*}{ N 1} & Pr N & 365,7 & 6,70 & 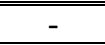 & 11.386 & 14.111 \\
\hline & $\begin{array}{l}\text { arg assent } \mathrm{N} 1 \\
\text { arg assent } \mathrm{N} 2\end{array}$ & $\begin{array}{l}9,2 \\
9,7\end{array}$ & $\begin{array}{l}4,69 \\
4,94\end{array}$ & 4,81 & - & $\begin{array}{l}- \\
-\end{array}$ \\
\hline \multirow[b]{2}{*}{ N 2} & $\operatorname{Pr} N$ & 439,0 & 8,04 & - & 11.372 & 12.093 \\
\hline & $\begin{array}{l}\text { arg assent } \mathrm{N} 1 \\
\arg \text { assent } \mathrm{N} 2\end{array}$ & $\begin{array}{r}10,1 \\
9,8 \\
\end{array}$ & $\begin{array}{l}5,14 \\
4,99 \\
\end{array}$ & 5,07 & - & - \\
\hline \multirow[b]{2}{*}{ N 3} & $\operatorname{Pr} N$ & 369,6 & 6,77 & - & 12.211 & 14.596 \\
\hline & $\begin{array}{l}\text { arg assent } \mathrm{N} 1 \\
\arg \text { assent } \mathrm{N} 2\end{array}$ & $\begin{array}{l}9,5 \\
9,4\end{array}$ & $\begin{array}{l}4,84 \\
4,79\end{array}$ & 4,81 & - & - \\
\hline \multirow[b]{2}{*}{ NN 1} & Pr NN & 254,3 & 4,66 & - & 13.602 & 14.443 \\
\hline & $\begin{array}{l}\text { arg assent } \mathrm{N} 1 \\
\text { arg assent } \mathrm{N} 2 \\
\text { arg revest } \mathrm{N} 1 \\
\text { arg revest } \mathrm{N} 2\end{array}$ & $\begin{array}{r}10,3 \\
11,4 \\
9,5 \\
10,7 \\
\end{array}$ & $\begin{array}{l}5,25 \\
5,81 \\
4,84 \\
5,45 \\
\end{array}$ & 5,53 & $\begin{array}{l}- \\
- \\
- \\
-\end{array}$ & $\begin{array}{l}- \\
- \\
- \\
-\end{array}$ \\
\hline \multirow[b]{2}{*}{ NN 2} & $\operatorname{Pr} N N$ & 333,9 & 6,12 & - & 12.655 & 14.298 \\
\hline & $\begin{array}{l}\text { arg assent } \mathrm{N} 1 \\
\text { arg assent } \mathrm{N} 2 \\
\text { arg revest } \mathrm{N} 1 \\
\text { arg revest N2 }\end{array}$ & $\begin{array}{l}11,2 \\
11,5 \\
10,7 \\
10,4\end{array}$ & $\begin{array}{l}5,70 \\
5,86 \\
5,45 \\
5,30\end{array}$ & 5,37 & $\begin{array}{l}- \\
- \\
- \\
-\end{array}$ & $\begin{array}{l}- \\
- \\
- \\
-\end{array}$ \\
\hline \multirow[b]{2}{*}{ NN 3} & $\operatorname{Pr} N N$ & 336,9 & 6,17 & - & 13.626 & 13.626 \\
\hline & $\begin{array}{l}\text { arg assent } \mathrm{N} 1 \\
\text { arg assent } \mathrm{N} 2 \\
\text { arg revest } \mathrm{N} 1 \\
\text { arg revest } \mathrm{N} 2\end{array}$ & $\begin{array}{l}10,2 \\
11,1 \\
10,5 \\
10,7\end{array}$ & $\begin{array}{l}5,19 \\
5,65 \\
5,35 \\
5,45\end{array}$ & $\begin{array}{l}5,42 \\
5,40\end{array}$ & $\begin{array}{l}- \\
- \\
- \\
-\end{array}$ & $\begin{array}{l}- \\
- \\
- \\
-\end{array}$ \\
\hline \multirow[b]{2}{*}{ NR 1} & Pr NR & 314,6 & 5,76 & - & 13.602 & 14.690 \\
\hline & $\begin{array}{l}\text { arg assent } \mathrm{N} 1 \\
\text { arg assent } \mathrm{N} 2 \\
\text { arg revest } \mathrm{R} 1 \\
\text { arg revest } \mathrm{R} 2\end{array}$ & $\begin{array}{l}12,3 \\
11,4 \\
11,5 \\
10,9\end{array}$ & $\begin{array}{l}6,26 \\
5,81 \\
5,86 \\
5,55 \\
\end{array}$ & 5,70 & $\begin{array}{l}- \\
- \\
- \\
-\end{array}$ & $\begin{array}{l}- \\
- \\
- \\
-\end{array}$ \\
\hline \multirow[b]{2}{*}{ NR 2} & Pr NR & 314,6 & 5,76 & - & 12.655 & 15.294 \\
\hline & $\begin{array}{l}\text { arg assent } \mathrm{N} 1 \\
\text { arg assent } \mathrm{N} 2 \\
\text { arg revest } \mathrm{N} 1 \\
\text { arg revest } \mathrm{N} 2\end{array}$ & $\begin{array}{l}11,8 \\
10,6 \\
10,6 \\
10,7 \\
\end{array}$ & $\begin{array}{l}6,01 \\
5,40 \\
5,40 \\
5,45 \\
\end{array}$ & 5,70 & $\begin{array}{l}- \\
- \\
- \\
-\end{array}$ & $\begin{array}{l}- \\
- \\
- \\
-\end{array}$ \\
\hline \multirow[b]{2}{*}{ NR 3} & Pr NR & 361,6 & 6,62 & - & 13.626 & 13.656 \\
\hline & $\begin{array}{l}\text { arg assent } \mathrm{N} 1 \\
\text { arg assent } \mathrm{N} 2 \\
\text { arg revest } \mathrm{N} 1 \\
\text { arg revest } \mathrm{N} 2\end{array}$ & $\begin{array}{l}11,3 \\
13,2 \\
12,4 \\
12,9 \\
\end{array}$ & $\begin{array}{l}5,76 \\
6,72 \\
6,32 \\
6,57 \\
\end{array}$ & 6,44 & $\begin{array}{l}- \\
- \\
- \\
-\end{array}$ & $\begin{array}{l}- \\
- \\
- \\
-\end{array}$ \\
\hline
\end{tabular}

Data de assentamento: 16 de julho

Data de revestimento: 20 de julho

Data de ensaio: 8 e 9 de agosto 


\section{$\underline{\text { ANEXO }} \underline{C}$}

$\underline{\text { ARGAMASSAS }} \underline{\text { DE ASSENTAMENTO }} \underline{E} \underline{\text { DE }} \underline{\text { REVESTIMENTO }}$ 
Tabela C.1 - Resistência de aderência à tração

\begin{tabular}{|c|c|c|c|c|c|c|c|c|c|c|}
\hline $\begin{array}{c}\text { natureza } \\
\text { da parede }\end{array}$ & $\mathrm{Pi}(\mathrm{g})$ & ponto & $F(\mathrm{Kg})$ & $\begin{array}{l}\text { Área } \\
\left(\mathrm{cm}^{2}\right)\end{array}$ & unitário & $\begin{array}{l}\text { Ra } \\
\text { méc }\end{array}$ & $\begin{array}{l}\text { (MPa) } \\
\text { dia }\end{array}$ & $\mathrm{Sd}$ & CV (\%) & $\begin{array}{l}\text { local de } \\
\text { ruptura }\end{array}$ \\
\hline "RR 1 & 8.410 & 4 & 50,54 & 18,50 & 0,273 & \multirow{10}{*}{\multicolumn{2}{|c|}{0,39}} & \multirow{10}{*}{0,17} & \multirow{10}{*}{42,1} & \multirow{10}{*}{ b } \\
\hline RR 2 & 3.400 & 4 & 31,75 & 18,83 & 0,169 & & & & & \\
\hline RR 3 & 6.160 & 5 & 30,58 & 18,99 & 0,161 & & & & & \\
\hline RR 4 & 20.510 & 4 & 95,91 & 18,83 & 0,509 & & & & & \\
\hline RR 5 & 23.060 & 4 & 105,48 & 18,70 & 0,564 & & & & & \\
\hline RR 6 & 10.250 & 4 & 57,44 & 18,78 & 0,306 & & & & & \\
\hline RR 7 & 19.150 & 4 & 90,81 & 18,73 & 0,485 & & & & & \\
\hline RR 8 & 16.290 & 4 & 80,09 & 18,73 & 0,428 & & & & & \\
\hline RR 9 & 13.960 & 4 & 71,35 & 18,70 & 0,381 & & & & & \\
\hline RR 10 & 27.430 & 4 & 121,86 & 18,63 & 0,654 & & & & & \\
\hline RR 1 fiss & 1.350 & 4 & 24,06 & 18,75 & 0,128 & \multirow{10}{*}{\multicolumn{2}{|c|}{0,12}} & \multirow{10}{*}{0,01} & \multirow{10}{*}{8,9} & \multirow{10}{*}{ b } \\
\hline RR 2 fiss & 3.800 & 6 & 22,57 & 18,68 & 0,121 & & & & & \\
\hline RR 3 fiss & 3.800 & 6 & 22,57 & 18,73 & 0,121 & & & & & \\
\hline RR 4 fiss & 4.610 & 6 & 23,33 & 18,93 & 0,123 & & & & & \\
\hline RR 5 fiss & 5.290 & 6 & 23,97 & 18,86 & 0,127 & & & & & \\
\hline RR 6 fiss & 3.520 & 6 & 22,31 & 18,68 & 0,119 & & & & & \\
\hline RR 7 fiss & 3.710 & 6 & 22,49 & 18,81 & 0,120 & & & & & \\
\hline RR 8 fiss & - & 6 & 19,00 & 18,83 & 0,101 & & & & & \\
\hline RR 9 fiss & - & 6 & 19,00 & 18,73 & 0,101 & & & & & \\
\hline RR 10 fiss & - & 6 & 19,00 & 18,17 & 0,105 & & & & & \\
\hline RN 1 & - & - & - & - & - & \multirow{5}{*}{1,03} & \multirow{10}{*}{0,65} & 0,00 & 0,0 & - \\
\hline RN 2 & 20.000 & 1 & 206,40 & 18,78 & $>1,099$ & & & & & - \\
\hline RN 3 & 19.100 & 2 & 154,99 & 18,70 & $>0,829$ & & & & & \\
\hline RN 4 & 21.150 & 1 & 217,18 & 18,68 & $>1,163$ & & & 0,14 & 14,1 & c \\
\hline RN 5 & 18.550 & 1 & 192,81 & 18,83 & $>1,024$ & & & & & \\
\hline RN 6 & 18.150 & 3 & 114,29 & 18,63 & 0,614 & \multirow{5}{*}{0,35} & & & \multirow{5}{*}{46,2} & \multirow{5}{*}{ D } \\
\hline RN 7 & 9.100 & 3 & 66,78 & 18,86 & 0,354 & & & & & \\
\hline RN 8 & 4.850 & 1 & 64,44 & 18,81 & 0,343 & & & 0,16 & & \\
\hline RN 9 & 3.350 & 2 & 42,85 & 18,83 & 0,228 & & & & & \\
\hline RN 10 & 2.150 & 1 & 39,15 & 18,70 & 0,209 & & & & & \\
\hline
\end{tabular}

$\begin{array}{ll}\text { a: interface revestimento pastilha } \\ \text { local de ruptura: } & \text { b: interface revestimento/substrato } \\ \text { c: argamassa de revestimento } \\ \text { d: ruptura do substrato }\end{array}$

constantes do dispositivo

\begin{tabular}{c|cccccc} 
ponto & 1 & 2 & 3 & 4 & 5 & 6 \\
\hline valor da constante & 9,37 & 7,12 & 5,25 & 3,75 & 1,88 & 0,94
\end{tabular}




\begin{tabular}{|c|c|c|c|c|c|c|c|c|c|c|}
\hline \multirow{3}{*}{$\begin{array}{c}\begin{array}{c}\text { natureza } \\
\text { da parede }\end{array} \\
\text { NN } 1\end{array}$} & \multirow{2}{*}{$\mathrm{Pi}(\mathrm{g})$} & \multirow{2}{*}{ ponto } & \multirow{2}{*}{$\mathrm{F}(\mathrm{Kg})$} & \multirow{2}{*}{$\begin{array}{l}\text { Área } \\
\left(\mathrm{cm}^{2}\right)\end{array}$} & \multicolumn{5}{|c|}{ "Ra (MPa) } & \multirow{2}{*}{$\begin{array}{l}\text { local de } \\
\text { ruptura }\end{array}$} \\
\hline & & & & & unitário & & dia & $\mathrm{Sd}$ & CV (\%) & \\
\hline & 12.250 & 2 & 106,22 & 18,60 & 0,571 & \multirow{4}{*}{0,75} & \multirow{10}{*}{0,75} & \multirow{4}{*}{0,19} & \multirow{4}{*}{25} & \multirow{4}{*}{ c } \\
\hline NN 2 & 11.250 & 1 & 124,41 & 18,83 & 0,661 & & & & & \\
\hline NN 3 & 18.400 & 1 & 191,41 & 19,01 & 1,007 & & & & & \\
\hline NN 4 & 17.550 & 2 & 143,96 & 18,78 & 0,767 & & & & & \\
\hline NN 5 & 22.750 & 2 & 180,98 & 18,30 & 0,989 & \multirow{6}{*}{0,75} & & \multirow{6}{*}{0,30} & \multirow{6}{*}{39,5} & \multirow{6}{*}{ b } \\
\hline NN 6 & 7.950 & 2 & 75,604 & 18,20 & 0,415 & & & & & \\
\hline NN 7 & 17.700 & 2 & 145,02 & 18,63 & 0,779 & & & & & \\
\hline NN 8 & 17.600 & 2 & 144,31 & 18,60 & 0,776 & & & & & \\
\hline NN 9 & 5.900 & 1 & 74,28 & 18,70 & 0,397 & & & & & \\
\hline NN 10 & 20.450 & 1 & 210,62 & 18,73 & 1,125 & & & & & \\
\hline NR 1 & 7.200 & 2 & 70,26 & 18,73 & 0,375 & \multirow{6}{*}{0,59} & \multirow{10}{*}{0,54} & \multirow{6}{*}{0,24} & \multirow{6}{*}{40} & \multirow{6}{*}{ d } \\
\hline NR 2 & 6.600 & 2 & 65,99 & 18,81 & 0,351 & & & & & \\
\hline NR 3 & 16.900 & 2 & 139,33 & 18,55 & 0,751 & & & & & \\
\hline NR 4 & 11.600 & 2 & 101,59 & 18,73 & 0,542 & & & & & \\
\hline NR 5 & 22.950 & 2 & 182,40 & 18,78 & 0,971 & & & & & \\
\hline NR 6 & 11.750 & 2 & 102,66 & 18,75 & 0,547 & & & & & \\
\hline NR 7 & 6.500 & 2 & 65,28 & 18,70 & 0,349 & \multirow{4}{*}{0,48} & & \multirow{4}{*}{0,16} & \multirow{4}{*}{32,7} & \multirow{4}{*}{$b$} \\
\hline NR 8 & 9.600 & 2 & 87,35 & 18,73 & 0,466 & & & & & \\
\hline NR 9 & 7.750 & 2 & 74,18 & 18,86 & 0,393 & & & & & \\
\hline NR 10 & 15.800 & 2 & 131,50 & 18,81 & 0,699 & & & & & \\
\hline NR 1 fiss & 22.000 & 5 & 60,36 & 18,68 & 0,323 & 0,44 & \multirow{10}{*}{0,38} & 01 & 386 & d \\
\hline NR 2 fiss & 23.550 & 4 & 107,31 & 18,96 & 0,566 & & & & & u \\
\hline NR 3 fiss & 10.900 & 2 & 96,61 & 18,81 & 0,514 & \multirow{8}{*}{0,36} & & \multirow{8}{*}{0,25} & & \\
\hline NR 4 fiss & 17.450 & 2 & 143,24 & 18,70 & 0,766 & & & & & \\
\hline NR 5 fiss & - & 2 & 19,00 & 18,65 & 0,102 & & & & & \\
\hline NR 6 fiss & - & 2 & 19,00 & 18,81 & 0,101 & & & & 696 & $h_{1}$ \\
\hline NR 7 fiss & 12.200 & 4 & 64,75 & 18,68 & 0,347 & & & & by,o & D \\
\hline NR 8 fiss & 2.950 & 3 & 34,49 & 18,86 & 0,183 & & & & & \\
\hline NR 9 fiss & 6.950 & 4 & 45,06 & 18,81 & 0,240 & & & & & \\
\hline NR 10 fiss & 13.850 & 2 & 117,61 & 18,83 & 0,625 & & & & & \\
\hline
\end{tabular}


Tabela C.2 - Resistência à compressão das argamassas de assentamento $e$ de revestimento das paredes destinadas ao ensaio de resistência da aderência à tração

\begin{tabular}{|c|c|c|c|c|c|c|}
\hline argamassa & parede & $\mathrm{F}(\mathrm{kN})$ & $\mathrm{f}_{\mathrm{a}, 33}$ & $\mathrm{~Pa}$ & $\overline{\mathrm{Sd}(\mathrm{MPa})}$ & CV (\%) \\
\hline \multirow{6}{*}{ assentamento } & N1 & 15,00 & 7,639 & \multirow{3}{*}{7,42} & \multirow{3}{*}{0,23} & \multirow{3}{*}{3,10} \\
\hline & N2 & 14,60 & 7,436 & & & \\
\hline & N3 & 14,10 & 7,181 & & & \\
\hline & R1 & 14,70 & 7,487 & \multirow{3}{*}{7,98} & \multirow{3}{*}{0,43} & \multirow{3}{*}{5,35} \\
\hline & R2 & 16,10 & 8,200 & & & \\
\hline & R3 & 16,20 & 8,251 & & & \\
\hline \multirow{8}{*}{ revestimento } & $\overline{N N 1}$ & 11,70 & 5,959 & \multirow{2}{*}{5,83} & \multirow{2}{*}{0,18} & \multirow{2}{*}{3,09} \\
\hline & NN2 & 11,20 & 5,704 & & & \\
\hline & NR1 & 14,80 & 7,538 & \multirow{2}{*}{7,97} & \multirow{2}{*}{0,61} & \multirow{2}{*}{7,68} \\
\hline & NR2 & 16,50 & 8,403 & & & \\
\hline & RN1 & 16,90 & 8,607 & \multirow{2}{*}{7,77} & \multirow{2}{*}{1,19} & \multirow{2}{*}{15,30} \\
\hline & RN2 & 13,60 & 6,926 & & & \\
\hline & RR1 & 15,90 & 8,098 & \multirow{2}{*}{9,55} & \multirow{2}{*}{2,05} & \multirow{2}{*}{21,50} \\
\hline & RR2 & 21,60 & 11,001 & & & \\
\hline
\end{tabular}

Tabela C.3 - Módulo de elasticidade secante

\begin{tabular}{c||c|c|cc|cc}
\hline \hline série & $F(k N)$ & $f_{a, 18}(\mathrm{MPa})$ & \multicolumn{2}{|c|}{ Ea (MPa) } & Sd (MPa) & CV (\%) \\
\hline \hline R1 & 90 & 5,09 & 6.132 & & & \\
R2 & 85 & 4,81 & 6.507 & 6.244 & 228 & 3,66 \\
R3 & 85 & 4,81 & 6.093 & & & \\
\hline N1 & 95 & 5,38 & 10.173 & & & \\
N2 & 95 & 5,38 & 7.862 & 9.019 & 1.156 & 12,81 \\
N3 & 95 & 5,38 & 9.022 & & & \\
\hline \hline
\end{tabular}


Tabela C.4 - Análise da profundidade de carbonatação das argamassas de revestimento

\begin{tabular}{c||cc|cc|cc|cc}
\hline \hline tipo da argamassa & \multicolumn{2}{|c|}{$\mathrm{RR}$} & \multicolumn{2}{c|}{$\mathrm{NR}$} & \multicolumn{2}{c|}{$\mathrm{NN}$} & \multicolumn{2}{c}{$\mathrm{RN}$} \\
\hline \hline idade (dias) & 10 & 19 & 10 & 19 & 10 & 19 & 10 & 19 \\
\hline \hline & 1,20 & 1,38 & 0,57 & 1,26 & 0,03 & 0,63 & 0,17 & 0,53 \\
& 0,60 & 1,43 & 0,27 & 1,46 & 0,13 & 0,35 & 0,03 & 0,84 \\
& 0,60 & 1,61 & 0,40 & 0,54 & 0,07 & 0,45 & 0,32 & 0,45 \\
& 0,36 & 1,26 & 0,80 & 1,55 & 0,27 & 0,55 & 0,47 & 0,32 \\
& 0,97 & 1,22 & 0,73 & 1,48 & 0,30 & 0,28 & 0,02 & 0,62 \\
& 0,70 & 1,19 & 1,17 & 1,42 & 0,05 & 0,31 & 0,09 & 0,54 \\
& 0,30 & 1,92 & 1,60 & 1,07 & 0,01 & 0,42 & 0,13 & 0,37 \\
& 0,37 & 1,04 & 0,43 & 1,23 & 0,17 & 0,61 & 0,01 & 0,62 \\
& 0,30 & 1,31 & 0,40 & 0,96 & 0,11 & 0,46 & 0,23 & 0,43 \\
& 0,20 & 1,41 & 0,80 & 1,13 & 0,32 & 0,52 & 0,03 & 0,59 \\
& 0,60 & 0,93 & 0,10 & 1,66 & 0,47 & 0,28 & 0,01 & 0,74 \\
& 0,90 & 1,51 & 1,13 & 1,37 & 0,26 & 0,38 & 0,43 & 0,52 \\
& 0,01 & 1,08 & 0,77 & 1,17 & 0,08 & 0,35 & 0,08 & 0,59 \\
& 0,30 & 1,87 & 0,47 & 1,30 & 0,18 & 0,56 & 0,28 & 0,44 \\
& 0,53 & 1,13 & 0,27 & 1,35 & 0,42 & 0,35 & 0,01 & 0,34 \\
& 0,50 & 0,93 & 0,03 & 1,47 & 0,17 & 0,67 & 0,15 & 0,67 \\
& 0,53 & 1,31 & 0,63 & 1,51 & 0,27 & 0,96 & 0,01 & 0,56 \\
& 0,70 & 1,43 & 0,57 & 1,09 & 0,04 & 0,76 & 0,08 & 0,71 \\
& 0,90 & 1,10 & 0,57 & 1,93 & 0,01 & 0,29 & 0,32 & 0,46 \\
& 0,73 & 1,24 & 0,27 & 1,27 & 0,33 & 0,23 & 0,17 & 0,36 \\
& 1,20 & 1,33 & 0,27 & 1,35 & 0,51 & 0,48 & 0,11 & 0,29 \\
& 0,60 & 1,47 & 0,80 & 0,96 & 0,43 & 0,67 & 0,41 & 0,47 \\
& 0,67 & 1,58 & 0,70 & 1,11 & 0,16 & 0,37 & 0,21 & 0,69 \\
& 0,87 & 1,27 & 0,63 & 1,19 & 0,43 & 0,74 & 0,33 & 0,61 \\
& 0,37 & 1,58 & 0,70 & 1,12 & 0,19 & 0,63 & 0,20 & 0,68 \\
& 0,60 & 1,30 & 0,67 & 1,51 & 0,30 & 0,49 & 0,07 & 0,49 \\
& 0,27 & 1,02 & 0,43 & 1,21 & 0,07 & 0,92 & 0,25 & 0,57 \\
& 0,20 & 1,08 & 0,73 & 1,63 & 0,32 & 0,35 & 0,13 & 0,27 \\
& 0,33 & 1,47 & 0,33 & 1,63 & 0,09 & 0,73 & 0,09 & 0,58 \\
& 0,83 & 1,16 & 0,30 & 1,31 & 0,37 & 0,43 & 0,01 & 0,43 \\
& 1,67 & 1,58 & 0,37 & 1,05 & 0,02 & 0,35 & 0,14 & 0,38 \\
& 1,43 & 1,17 & 0,47 & 1,33 & 0,07 & 0,76 & 0,80 & 0,36 \\
& 0,60 & 1,06 & 0,27 & 1,63 & 0,20 & 0,46 & 0,01 & 0,58 \\
& 0,47 & 0,53 & 0,57 & 1,03 & 0,28 & 0,68 & 0,48 & 0,62 \\
& 0,90 & 1,00 & 0,23 & 1,29 & 0,13 & 0,54 & 0,02 & 0,68 \\
& 1,13 & 1,26 & 0,57 & 1,51 & 0,34 & 0,72 & 0,09 & 0,66 \\
\hline \hline
\end{tabular}

